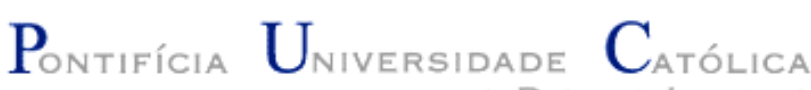

Edson Diniz Nóbrega Junior

\begin{abstract}
A relação escola-família-vizinhança na favela da Maré e o Programa Escolas do Amanhã/Bairro Educador
\end{abstract}

Tese de Doutorado

Tese apresentada como requisito parcial para obtenção do grau de Doutor pelo Programa de Pós-graduação em Educação do Departamento de Educação do Centro de Teologia e Ciências Humanas da PUC-Rio.

Orientadora: Prof ${ }^{\mathrm{a}}$ Alicia Maria Catalano de Bonamino Co-orientador: Prof. Marcelo Tadeu Baumann Burgos 
Edson Diniz Nóbrega Junior

\begin{abstract}
A relação escola-família-vizinhança na favela da Maré e o Programa Escolas do Amanhã/Bairro Educador
\end{abstract}

Tese apresentada como requisito parcial para obtenção do grau de Doutor pelo Programa de Pós-graduação em Educação do Departamento de Educação do Centro de Teologia e Ciências Humanas da PUC-Rio. Aprovada pela Comissão Examinadora abaixo assinada.

Profa. Alícia Maria Catalano de Bonamino Orientadora

Departamento de Educação - PUC-Rio

Prof ${ }^{\circ}$. Marcelo Tadeu Baumann Burgos

Co-orientador

Departamento de Sociologia - PUC-Rio

Profa. Cynthia Paes de Carvalho Departamento de Educação- PUC-Rio

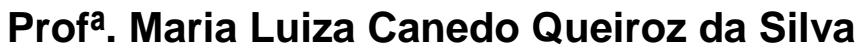
Departamento de Educação - PUC-Rio

Prof ${ }^{\mathrm{a}}$. Helena Maria Bomeny Garchet Universidade do Estado do Rio de Janeiro

Profa. Tania de Freitas Resende Universidade Federal de Minas Gerais

Prof ${ }^{a}$ Monah Winograd Coordenadora Setorial do Centro de Teologia e Ciências Humanas

PUC-Rio

Rio de Janeiro, 8 de maio de 2017. 
Todos os direitos reservados. É proibida a reprodução total ou parcial do trabalho sem autorização do autor, do orientador e da universidade.

\section{Edson Diniz}

Possui graduação em história pela Universidade do Estado do Rio de Janeiro (1999) e mestrado em Sociologia da Educação pela Pontifícia Universidade Católica do Rio de Janeiro (2007). Atuou como professor de História nas redes públicas e privadas do Rio de Janeiro ao longo de 20 anos. Fundou o Núcleo de Memória e Identidade da Maré (NUMIM). Publicou dois livros sobre a memória dos moradores do conjunto de favelas da Maré. Tem trabalhado com os seguintes temas: História das favelas, memória e identidade, segurança pública e escolas públicas (relação escola-família, escolas eficazes, equidade, políticas públicas).

Ficha Catalográfica

Diniz, Edson Nóbrega Junior

A relação escola-família-vizinhança na favela da Maré e o Programa Escolas do Amanhã/Bairro Educador / Edson Diniz Nóbrega Junior ; orientadora: Alicia Maria Catalano de Bonamino; co-orientador: Burgos, Marcelo Tadeu Baumann. - 2017.

203 f. : il. color. ; $30 \mathrm{~cm}$

Tese (doutorado)-Pontifícia Universidade Católica do Rio de Janeiro, Departamento de Educação, 2017.

Inclui bibliografia

1. Educação - Teses. 2. Relação escola-famíliavizinhança. 3. Escolas do Amanhã. 4. Bairro Educador. 5. Territórios populares. 6. Favela da Maré. I. Bonamino, Alicia Maria Catalano de. II. Pontifícia Universidade Católica do Rio de Janeiro. Departamento de Educação. III. Título. 
À Ana Barros, minha mulher, amiga e companheira de todas as horas, com quem tenho a alegria de compartilhar a vida e a beleza do amor. 


\section{Agradecimentos}

À minha orientadora, Alicia Bonamino, pela inestimável competência, sabedoria e carinho com que me ajudou a concretizar este trabalho. Suas orientações foram sempre seguras e firmes, sem jamais perder a ternura.

Ao meu co-orientador, Marcelo Burgos, pelas orientações precisas, pelas discussões conceituais sempre relevantes e por acreditar no potencial de meu trabalho.

À CAPES, ao CNPq e à PUC-Rio pelos auxílios concedidos, sem os quais este trabalho não poderia ter sido realizado.

Ao Departamento de Educação da PUC-Rio e seus professores e professoras pela excelência das aulas e ensinamentos valiosos.

À Secretaria Municipal de Educação do Rio de Janeiro (SME-RJ) pela autorização para a entrada nas escolas de forma a viabilizar a investigação qualitativa da pesquisa.

Às direções e professores das escolas da Maré pela recepção e abertura ao diálogo sem os quais este trabalho não teria sido possível.

Às famílias da Maré pela colaboração e pelas conversas francas e animadas, tão fundamentais para este trabalho.

Aos colegas do grupo de pesquisa do Laboratório da Avaliação da Educação LAEd -, que tanto ajudaram nas discussões sobre o projeto que originou este trabalho e pela torcida para que tudo desse certo.

Aos professores da UFRJ, Joaquim Fernando e Antonio Guerra, pela compreensão, amizade e incentivo sem os quais este trabalho não teria sido possível.

Aos amigos e amigas da REDES da Maré com quem compartilho dores e alegrias diárias na nossa Maré. Em especial à Eliana Sousa Silva e Jaílson Souza e Silva com quem compartilho o sonho de uma cidade mais justa e mais igual.

Aos milhares de moradores da Favela da Maré por quem tenho imensa admiração, respeito e com quem aprendo a cada dia o valor da vida e da coragem para seguir em frente.

À minha família, em especial ao meu pai Edson e à minha mãe Nina, que me ensinaram e ensinam tanto sobre a solidariedade, o amor e a coragem de encarar a vida sempre com alegria. 


\section{Resumo}

Diniz, Edson Nóbrega Junior; Bonamino, Alicia Maria Catalano de. A relação escola-família-vizinhança na favela da Maré e o Programa Escolas do Amanhã/ Bairro Educador. Rio de Janeiro, 2017. 203p. Tese de Doutorado - Departamento de Educação, Pontifícia Universidade Católica do Rio de Janeiro.

Este trabalho procura contribuir para o debate sobre as relações entre escolas públicas, famílias de origem popular e vizinhança escolar, tendo como referência territórios pobres da cidade, notadamente o conjunto de favelas da Maré. A pesquisa aborda, especificamente, as relações no âmbito do Programa Escolas do Amanhã/ Bairro Educador (PEA/BE), política que se coloca na perspectiva, tanto das novas formas de educação prioritária e compensatória para escolas em territórios vulneráveis, como da reconfiguração dos espaços e tempos escolares e de uma visão ampliada dos espaços educacionais. Do ponto de vista metodológico, um estudo de abordagem qualitativa dessa experiência foi conduzido em escolas públicas municipais de Ensino Fundamental que se caracterizam por serem participantes e não participantes do PEA/BE na Maré. Com o objetivo de indagar a possível existência de diferenças nas relações entre escola-família-vizinhança em escolas que se distinguem basicamente por serem ou não participantes do $\mathrm{PEA} / \mathrm{BE}$, foram realizadas entrevistas com diferentes agentes educacionais, escolares, familiares e sociais envolvidos direta ou indiretamente no programa, buscando conhecer a percepção deles acerca dessa política. Particularmente, o Projeto Bairro Educador foi desenvolvido no âmbito do Programa Escolas do Amanhã da Secretaria Municipal de Educação da cidade do Rio de Janeiro (SME-RJ), com a finalidade de aproximar as escolas públicas localizadas em territórios marcados pela violência e que apresentam resultados abaixo da média da sua respectiva rede de ensino, das famílias e de suas vizinhanças, através do uso do território como ferramenta educativa e pedagógica. Os principais resultados da pesquisa permitem afirmar que o Programa Escolas de Amanhã/Bairro Educador não deixou um legado suficientemente consistente a ponto de marcar uma diferença substancial nas relações escolas-famíliavizinhança entre as escolas que dele participaram. Uma das possíveis explicações para isso diz respeito à falta de alinhamento entre as orientações do PEA/BE e sua 
implementação, bem como aos problemas de externalidade, fragmentação e segmentação da coordenação político-pedagógica do BE e à falta de uma orientação mais enfática da SME-RJ acerca dos caminhos a percorrer para atingir os objetivos propostos. O trabalho se encerra com a apresentação de recomendações que pretendem contribuir para a orientação de políticas públicas que tenham como objetivo a aproximação entre escolas-famílias-vizinhança.

\section{Palavras-chaves}

Relação escola-família-vizinhança; Escolas do Amanhã; Bairro Educador; Territórios populares; Favela da Maré; Escola pública; Políticas de Educação Prioritária 


\section{Abstract}

Diniz, Edson Nóbrega Junior; Bonamino, Alicia Maria Catalano de. (Advisor) The relationship school-family-neighborhood in the favela da Maré and the Program Schools of Tomorrow/Educating Neighborhood. Rio de Janeiro, 2017. 203p. Tese de Doutorado - Departamento de Educação, Pontifícia Universidade Católica do Rio de Janeiro.

This study aims on discussing the relations among public schools, lowincome families, and the schools' neighborhood, considering poor areas in Rio de Janeiro, specially a community called Maré. The research focuses on the relations within Escolas do Amanhã / Educator Neighborhood (PEA/BE in Portuguese), which considers the perspective of new priority and compensatory ways of education driven to vulnerable areas, as well as school space and time adjustments. A qualitative study of this experience has been conducted in order to analyze elementary and middle public schools in Maré that participate or not in PEA/BE. The objective has been to question if there are differences in the relations among school, family and neighborhood, considering schools which participate in the program and schools which do not. Different educational, school, family and social agents have been interviewed in order to comprehend the way they see this policy. Educator Neighborhood project, in particular, has been developed within Escolas do Amanhã program by the Education Municipal Office (SME-RJ in Portuguese), with the goal of integrating public schools placed in violent areas and with low results in relation to their education network, families and neighborhood, considering territory as an educational and pedagogical tool. The main results of the research show that Escolas do Amanhã / Educator Neighborhood program did not leave a consistent result in building better school, family and neighborhood relations among the schools that participated in the program. One of the possible reasons for it may be the lack of a guideline between $\mathrm{PEA} / \mathrm{BE}$ and its implementation, as well as problems referring to its political-pedagogical coordination, such as its fragmentation and segmentation. This guideline could come from the Education Municipal Office, pointing to a path that leads to the program's objectives. Therefore, this thesis ends up with some recommendation about public policies that may contribute to closer relations among school, family and neighborhood. 


\section{Keywords}

Relations among school; Family and neighborhood; Escolas do Amanhã; Educator Neighborhood; Low-income areas; Maré community; Public school; Priority education policies 
O correr da vida embrulha tudo. A vida é assim: esquenta e esfria, aperta e daí afrouxa, sossega e depois desinquieta. O que ela quer da gente é coragem

Guimarães Rosa

Eu só quero é ser feliz Andar tranquilamente na favela onde eu nasci E poder me orgulhar E ter a consciência que o pobre tem seu lugar 


\section{Sumário}

1 Introdução

2 Da escola moderna à escola de massas 23

2.1 A escola moderna: um breve olhar sobre suas raízes 23 históricas

2.2 A "escola de massas"

2.3 As escolas eficazes: a escola faz diferença 31

2.4 Consolidação de um novo campo de investigação na 33 Sociologia da Educação

2.5 Escolas públicas e famílias populares: uma relação 35 conflituosa

3 As Políticas de Educação Prioritária (PEP)

3.1 Das políticas compensatórias às Políticas de Educação 42 Prioritárias (PEP)

3.1.1 A ZEP na França

3.1.2 A TEIP em Portugal

3.1.3 Da Carta de Barcelona às Cidades Educadoras

3.1.4 Do Bairro-Escola ao Bairro Educador

3.1.5 O Bairro-Escola de Nova Iguaçu

3.1.6 O Projeto Mais Educação

3.2 As três idades das PEP

5 Referências conceituais e metodologia da pesquisa

5.1 Definições iniciais

5.2 As lógicas antinômicas

5.30 mundo do aluno 
5.5 O lugar de moradias 88

5.6 O conceito de território 92

5.6.1 Comunidade ou favela? 96

5.7 A metodologia da pesquisa 98

$\begin{array}{ll}5.8 \text { Instrumentos de pesquisa } & 99\end{array}$

6 A relação escolas-famílias-vizinhança 103

6.1 A importância do lugar 104

6.2 Estudo de caso 105

7 O território: a Favela da Maré 113

$\begin{array}{ll}7.1 \text { A favela na cidade } & 113\end{array}$

$\begin{array}{ll}\text { 7.2 A Favela da Maré } & 117\end{array}$

80 que dizem os dados de desempenho da Maré 122

8.1 Dados educacionais da Maré 122

8.2 Desempenho das escolas da Maré 124

9 As percepções dos profissionais da escola e dos responsáveis 130 pelos alunos

9.1 Escola Azul 130

9.2 Escola Branca 133

9.3 Sobre as entrevistas 136

9.4 Categorias de análise 139

9.4.1 O mundo do aluno 141

9.4.2 O efeito vizinhança e a geografia objetiva e subjetiva das 145 oportunidades

9.4.3 As estruturas de oportunidades locais: a geografia das 146 oportunidades

9.4.4 Eficácia normativa 150

9.4.5 As fontes de informações 156

9.5 O efeito Vizinhança 160

9.6 A importância da relação escola-família-vizinhança 166 
9.7 Antinomia/relações armadilhadas 168

9.8 Encontros entre escola-família: um dia de reunião 169

9.9 Notas sobre o PEA/BE na Maré 177

10 Considerações finais 184

11 Referências bibliográficas 188

12 Anexos 192 


\section{Lista de tabelas}

Tabela 1 - Composição de populacional por comunidade/favela 118

Tabela 2 - Composição de renda segundo as comunidades/favelas

Tabela 3 - Dados das escolas da Maré: IDEB 2015 


\section{Lista de quadros}

Quadro 1 - Rendimentos 135

$\begin{array}{ll}\text { Quadro } 2 \text { - Entrevistados } & 136\end{array}$

$\begin{array}{ll}\text { Quadro } 3 \text { - Categorias de Análise } & 140\end{array}$ 


\section{Lista de gráficos}

Gráfico 1 - IDEB: Escolas da Maré 2007-2015 - anos iniciais 125

Gráfico 2 - Matemática - Prova Brasil escolas da Maré - 2005 e 126 2015

Gráfico 3 - Língua Portuguesa - Prova Brasil escolas da Maré 127 2005 e 2015

Gráfico 4 - Taxas de aprovação dos anos iniciais das escolas da 128 MARÉ ENTRE 2005 E 2015 


\section{1 \\ Introdução}

Meu tema de pesquisa se situa no campo dos estudos que abordam as relações entre escolas públicas e famílias de origem popular, tendo como referência o território. A decisão de trabalhar com essa questão remonta a minha própria experiência como estudante e, anos mais tarde, como professor de escolas públicas na Favela da Maré, Zona Norte da cidade do Rio de Janeiro.

Sempre me interessou a forma como professores, diretores e demais profissionais da escola se relacionavam com pais, mães e responsáveis pelas crianças mais pobres, que cada vez mais chegavam à escola pública. Em minhas experiências, seja na "sala dos professores", seja nos conselhos de classe, ou nas conversas de corredor com colegas de profissão, algo me inquietava: a impressão que tinha da escola não enxergar a criança por trás do aluno, o adulto por trás do pai ou da mãe e, muito menos, a família e seu território.

$\mathrm{Na}$ verdade, ainda hoje me intriga quando professores e professoras se dirigem aos responsáveis chamando-os de "pai" ou "mãe". Ora, se essas pessoas têm identidade, nome e uma história, por que não são tratadas assim?

Ainda na condição de aluno, lembro bem de minha mãe - na maioria das casas de origem popular, são elas que se responsabilizam mais diretamente pela educação escolar das crianças - ensinando o nome da professora e o quanto ela deveria ser respeitada. Aliás, mesmo nas casas mais humildes, essa quase reverência ao professor/professora permanece. Por outro lado, lembro-me de ouvir, em muitas reuniões e conselhos de classe, os alunos e alunas sendo chamados simplesmente por um número, quando não, por adjetivos nada lisonjeiros.

Obviamente existiam muitas exceções. Trabalhei em escolas e convivi com professores e professoras que, não apenas conheciam os responsáveis pelos alunos pelos nomes, mas sabiam em que condições as famílias de seus alunos e alunas viviam. Hoje, tenho plena consciência de quanto essa proximidade os ajudava na interação com as crianças e com a educação escolar delas.

No entanto, confesso que, também para mim, como professor, nunca foi simples me relacionar com as famílias de meus alunos e alunas, principalmente porque trabalhava em várias escolas - como muitos professores brasileiros - e, 
por isso, vivia "correndo" de uma escola à outra. Mas, talvez, o motivo mais importante fosse a crença, compartilhada por muitos de meus colegas, de que família e escolas tinham papeis diferentes a desempenhar e que cada instituição não deveria interferir no domínio da outra.

Só anos mais tarde, a partir do contato que tive com pesquisas - sobretudo no mestrado e no doutorado na PUC-Rio - quese debruçavam sobre as relações escola-família, é que pude novamente refletir sobre o tema. Havia me distanciado dele, mas ele me acompanhou, reconheço, todo esse tempo.

Retrospectivamente,pude me colocar a questão que me fez chegar até aqui: por que as relações entre escolas públicas e famílias de origem popular são marcadas pela distância e pela antinomia e carregadas de conflitos?

Hoje, não tenho dúvidas de que a relação escola-famílias é uma relação difícil. O problema é que os conflitos são naturalizados no cotidiano e aceitos como tal pelos agentes sociais envolvidos. Assim, a despeito do crescente interesse pelo tema - tanto na academia quanto no âmbito de governos dos mais diferentes matizes ideológicos -, essa relação permanece um desafio.

Acrescento a esse desafio a questão territorial. Acredito ser impossível que as relações entre escolas públicas e famílias populares sejam discutidas e estudadas sem que as consideremos a partir da dimensão do lugar onde elas acontecem. O território, visto aqui como campo concreto onde estão inscritas as práticas, as trocas simbólicas e as relações de poder, constituiu-se como um dos elementos chave para o entendimento da relação escola-família. É a partir dele que se constroem as dinâmicas sociais que perpassam as relações entre os agentes e instituições envolvidos no trabalho escolar e na escolarização das novas gerações.

Minha aposta é de que, se escolas e famílias conseguirem se aproximar e caminharem juntas - compreendendo-se as especificidades de cada uma dessas instituições -, os benefícios para ambas serão grandes. No entanto, a aposta envolve a ideia de que a maior beneficiada será sempre a criança, sobretudo, a de origem popular. No momento em que o mundo escolar conseguir se comunicar mais, melhor e de forma horizontal com o mundo popular, o mundo do aluno, de onde vêm as crianças da escola pública, poderemos ter uma interação mais positiva entre ambos. Isso, por sua vez, poderá criar um ambiente mais favorável 
para o ensino-aprendizado já que as crianças poderão ser compreendidas sob uma perspectiva mais realista e menos estigmatizante.

Mais do que uma simples parceria, acredito que a escola e a família podem transformar suas relações em projetos de intervenção na realidade, de intervenção nas condições de vida e da sociabilidade no território.

Penso principalmente a relação escola-família a partir da escola, seu lado "mais forte", já que é esta instituição, em última instância, que tem o poder de conferir os títulos, o queé parte importante do capital cultural institucional a ser socialmente distribuído.

Por outro lado, em muitos territórios populares da cidade, a escola é a única instituição pública que está em contato e em interação direta com a população local. Ela é, na maioria das vezes, a instituição que absorve as demandas sociais mais urgentes, extrapolando suas atribuições de ensino escolar.

Por isso, mais do que uma simples instituição de ensino, a escola, nos territórios populares, pode cumprir um papel diferente, pode ajudar as pessoas que neles habitam a, por exemplo, encontrar novas oportunidades sociais e profissionais. A escola pode ajudar essas mesmas pessoas a construírem melhores condições de vida e a cobrarem do Estado e da sociedade projetos de desenvolvimento social, econômico e cultural para o território em que habitam.

Para tanto, é preciso que a escola esteja disposta a assumir novas funções em que pese sua tarefa principal: transformar os saberes produzidas pela sociedade em conhecimentos que podem ser ensinados - que incluem, entre outras questões, a disposição para ser uma espécie de "agência de desenvolvimento".Isso significa que a instituição escolar pode assumir a condição de catalisadora e, ao mesmo tempo, impulsionadora de ações, projetos e propostas que gerem desenvolvimento socioeconômico e cultural para seu entorno.

Podem ser desenvolvidas, com as comunidades do entorno, uma série de atividades, por exemplo, sobre o funcionamento das eleições. Isso pode ser feito sem "partidarização", ou seja, sem direcionar o voto, mas discutindo-se o papel de vereadores, deputados, prefeitos, governadores e presidente. Sabemos bem como é difícil para as comunidades mais pobres ter acesso a informações qualificadas acerca dos candidatos e de suas plataformas políticas. Essa seria uma forma interessante de contribuir para uma intervenção mais qualificada das comunidades do entorno escolar no quadro das eleições em uma cidade. 
A tarefa não é fácil, concordo. No entanto, o fato é que já existem muitas experiências nesse sentido. Muitas escolas, mesmo nos lugares mais pobres do Brasil e do mundo, quando integradas ao território e quando têm projetos de desenvolvimento integrados a ele, podem vir a ser uma força capaz de redefinir as relações locais em favor daqueles que mais precisam.

Nesse processo, no entanto, é preciso redefinir também as relações com as famílias que nele habitam. Mas, para redefinir a relação escola-família nos territórios populares, é preciso que se reconheça, em primeiro lugar, as dificuldades que se colocam no caminho, sejam elas a superação da antinomia entre escolas e famílias, de que fala Daniel Thin (2006), seja o desmonte de "relações armadilhadas", das quais fala Pedro Silva (2003), ou, seja ainda, o reconhecimento do "mundo do aluno", de que fala Marcelo Burgos (2014).

Para conhecer um pouco mais essas relações, nosso trabalho partiu do estudo de uma iniciativa da Prefeitura da Cidade do Rio de Janeiro chamada Programa Escolas do Amanhã e uma ação chamada de Bairro Educador (PEA/BE). Esse Programa foi implantado em 155 escolas localizadas em áreas "conflagradas" da cidade, em geral, em favelas onde existem confrontos armados entre grupos criminosos e a polícia.

O PEA/BE apresenta, em seus documentos fundadores, duas finalidades básicas: melhorar a educação escolar nas escolas atendidas e aproximar essas escolas das famílias e das comunidades do seu entorno.

É bom que se diga ainda aqui que minha intenção não é avaliar o efeito do Programa no desempenho escolar dos alunos e alunas das dez escolas atendidas na favela da Maré, território com o qual trabalhamos. O que pretendo é investigar se as escolas da favela da Maré participantes do PEA e, notadamente da iniciativa "Bairro Educador", conseguiram, na percepção dos seus profissionais, se aproximar das famílias de seus alunos e alunas. No mesmo movimento, interrogamos os responsáveis pelos alunos sobre sua percepção acerca de uma maior proximidade ou não da escola com seu mundo e com seu território.

Nesse sentido, o PEA/BE é o "pano de fundo" onde se desenrolam as relações escolas-família-vizinhança, enfocadas pela pesquisa. É a partir do desenho dessa política que me aproximo dos agentes sociais envolvidos para investigar as relações escola-família-vizinhança em duas escolas da Maré, uma escola participante e outra não participante do PEA/BE. 
O objetivo primeiro é estabelecer comparações entre as percepções dos profissionais da escola que vivenciaram duas experiências marcadas por políticas, a princípio, diferenciadas de inserção e mediação nas relações com as famílias e com a vizinhança escolar e seu território.

Pretendo, assim, compreender se há diferenças entre essas duas escolas na forma de triangular as relações com as famílias e a vizinhança, considerando sua participação ou não no PEA/BE.

O presente trabalho se divide em oito capítulos. No primeiro capítulo, faço um pequeno balanço do surgimento da "escola de massas" e um levantamento da literatura sobre o tema das relações escola-família-vizinhança, campo temático em que se insere meu trabalho; no segundo capítulo, discuto o surgimento das "Políticas de Educação Prioritária" na Europa e como elas influenciaram alguns Programas criados no Brasil; no terceiro capítulo, abordo com mais detalhes o PEA/BE Educador, seus objetivos e ações; no quarto capítulo, discuto as questões metodológicas e apresento a fundamentação teórica que me orienta e a partir da qual formulo minhas principais questões de pesquisa; no quinto capítulo, apresento três estudos de caso que discutem as relações escola-família-vizinhança e que nos foram úteis nos sentido de confrontar nossas questões teóricas a partir da prática; no sexto capítulo, apresento o território da Maré com mais detalhes; no sétimo capítulo, discuto os dados educacionais das escolas da Maré e faço um estudo preliminar sobre o desempenho das escolas; no último capítulo, apresento os resultados sistematizados a partir das impressões dos agentes sociais envolvidos na relação escola-família-vizinhança na Maré e, em seguida, apresento algumas considerações mais gerais sobre o trabalho de pesquisa apresentado aqui.

Espero que meu trabalho contribua para iluminar aspectos ainda obscuros na relação entre escolas e famílias, tendo sempre como referência fundamental a vizinhança escolar e o território. Espero poder contribuir para que profissionais da escola e famílias consigam entender melhor suas relações e, a partir daí, que possam construir iniciativas que ajudem a superar a distância que as separa.

Penso que diminuir tal distância/separação significa superar lógicas antinômicas de escolas e famílias na tarefa de socializar as crianças. Obviamente, isso exige mais do que boas intenções. Exige, na verdade, boas doses de sacrifícios, desprendimento e disposição para a abertura ao outro. Exige, ainda, uma firme disposição do poder público no sentido de consolidar políticas públicas 
que aproximem as duas principais instituições socializadoras das crianças: escolas e famílias, levando em conta o contexto onde se travam as relações entre elas. 


\section{2 \\ Da escola moderna à escola de massas}

\section{1}

A escola moderna: um breve olhar sobre suas raízes históricas

Crahay (2012), ao citar Durkheim e sua obra L'évoutionpédagogique em France, defende que a escola moderna deve sua origem a dois movimentos contraditórios e fundamentais para a modernidade: o Cristianismo e o Iluminismo (CRAHAY, 2012, p.16).

Ao falar do primeiro movimento, Durkheim afirma que o Cristianismo criou uma forma nova de conceber a socialização e a educação dos indivíduos mais jovens, rompendo com as formas desenvolvidas desde a Antiguidade. Nesta última, o processo de socialização e educação das crianças se preocupava basicamente em transmitir uma série de "talentos" considerados importantes para a vida. No entanto, eram muito mais "adornos", de acordo com Durkheim, que poderiam ir sendo construídos sobre os indivíduos. Era muito mais uma "armação externa" do que uma intervenção mais profunda sobre a personalidade desses indivíduos (ibid. p.17).

A ruptura provocada pelo Cristianismo se dá exatamente aí, ou seja, passouse a ver o indivíduo de forma global, nas suas dimensões racional e espiritual mais profundas, não apenas na aparência externa. Era preciso, para constituição de um "bom cristão", que cada indivíduo se sentisse e agisse como tal. Para criar esse sentimento, era necessário, então, educar moralmente o indivíduo partir de novos valores.

Isso significava inverter a fórmula da Antiguidade, ou seja, agora o cristianismo propõe que se aja sobre a personalidade e se inculque preceitos morais que ajudem a criar determinadas atitudes condizentes com o ser cristão. Por isso, era necessária uma instituição capaz de realizar essa tarefa, ou seja, educar as almas para que elas pudessem partilhar da comunidade cristã.

Em pouco tempo, as abadias passaram a congregar jovens que eram "isolados" do mundo para serem educados e protegidos na fé cristã. Nascia, assim, o "embrião da escola moderna", a partir das abadias, mosteiros e das catedrais católicas (id. 2002, p. 17). 
Cambi (1999) chama a atenção para o fato de que, com a Reforma Protestante - e a eventual criação da imprensa por Gutemberg -, cresceu a necessidade de ampliar o número de leitores da bíblia. Por conta disso, a ideia de uma instrução maior, que chegasse a todos, passou a ser defendida como forma de ampliar a salvação das almas e dar maior liberdade de escolha às pessoas no que tange ao uso de sua fé. Assim, a alfabetização da população entrou na pauta das sociedades que se guiavam agora pelos preceitos morais luteranos.

O próprio Lutero defendeu a importância da instrução escolar para os cristãos, a partir de uma série de discursos dirigidos aos políticos dos territórios alemães, onde ele operava a Reforma. Há um desses discursos que deixa clara a dimensão que o reformador alemão dava à instrução escolar, intitulado "Sermão sobre a necessidade de mandar os filhos à escola", de 1530 (CAMBI, 1999, p.249).

Assim, a escola moderna é, ao menos em parte, filha de uma nova compreensão do mundo a partir da espiritualidade e da moral cristã e, também, do reconhecimento da existência de uma determinada época da vida dos indivíduos, a infância, na qual os membros mais jovens das famílias e da sociedade precisam de proteção e cuidados especiais, bem diferentes do mundo adulto (ARIÈS, 2012).Por outro lado, essa mesma escola, como apontado acima, é igualmente filha de outro movimento fundamental, que a afirmou como instrumento do mundo moderno que então se construía: o Iluminismo.

Os "filósofos das luzes" determinaram, em contraposição à religião e ao ensino religioso, que a verdade só poderia ser alcançada a partir da razão e do conhecimento científico. Esta forma de conhecimento vinha se aprimorando deste a "Revolução Científica do século XVII" (CAMBI, op. cit, p. 303) e se consolidou nos séculos XVIII e XIX.

A partir daí, e cada vez mais, é a ciência que passa a ser - obviamente não sem resistência por parte das religiões - a essência do projeto de homem que se afirma na modernidade. Não é preciso dizer que a escola, como instrumento da modernidade, formadora do homem racional, estava inevitavelmente no centro dos debates acerca dos caminhos que deveriam ser percorridos pelas sociedades que se modernizavam rapidamente.

Aqui, porém, cabe uma ressalva importante: até o século XVIII, a escola ainda com muitas diferenças de um território a outro - é única. Ou seja, não havia 
uma separação rígida entre escolas para ricos e pobres ou entre plebeus e nobres (AIRÈS, op. cit.), embora os grupos sociais mais ricos constituíssem o estrato social que mais frequentasse uma escola ${ }^{1}$. A única exceção era o caso das mulheres, que estavam excluídas da escola e da escolarização, salvo em casos raros. Somente no final do século XIX e início do século XX, as mulheres puderem frequentar as escolas e, mesmo assim, com uma série de restrições importantes.

Voltando aos iluministas, Philippe Ariès e Marcel Chahay divergem sobre a posição dos filósofos das luzes quanto a maior ou menor abertura em relação à democratização do acesso aos estudos de alto nível. O primeiro afirma categoricamente que os iluministas, com poucas exceções, como Condocert, desejavam que a educação escolar, sobretudo em seu mais alto nível, permanecesse restrita a uma única classe social - certamente a economicamente mais rica, única capaz de levar até o fim os estudos mais longos e custosos enquanto ao povo deveria ser dispensado um ensino inferior (ibid., p. 128). Já Crahay (2012), utilizando-se justamente de Condocert, afirma exatamente o contrário, ou seja, que os iluministas defendiam a ideia de uma expansão escolar para todas as camadas da população.

O fato, porém, é que a escola moderna, contraditoriamente filha do Cristianismo e do Iluminismo, não dispensou o mesmo tratamento para todos, seja no momento de seu ingresso, seja em seu interior.

$\mathrm{Na}$ verdade, ela acabou por se consolidar como uma escola "dual", ao menos em países centrais como a França e a Inglaterra. Isso porque, para os grupos e classes sociais mais ricos, havia o caminho para os estudos mais prestigiados socialmente e, para os grupos e classes populares, havia caminhos menos prestigiados e mais ligados à prática e às carreiras técnicas intermediárias.

Contudo, tão logo a escola se firmou como instituição basilar das sociedades modernas, passou a ser alvo de muitas críticas, tanto daqueles que defendiam sua exclusividade para os grupos privilegiados - ao menos nos níveis mais avançados - tanto daqueles que a reivindicavam mais democrática. Assim, não surpreende as

\footnotetext{
${ }^{1}$ É preciso dizer que as escolas deste momento histórico ainda não são as escolas com a configuração que seria a marca da modernidade: uma classe de alunos, com um currículo rígido, disciplinado e obediente.
} 
muitas tentativas de reformar a escola, sobretudo entre finais do século XIX e meados do século $\mathrm{XX}$.

Uma das tentativas mais importantes de reforma da escola foi, sem dúvida, o movimento da Escola Nova, que ganhou força entre o final do século XIX e os anos de 1930 do século XX. Esse movimento criou uma série de escolas experimentais como reação ao que seus criadores denominavam de "modelo tradicional de escola". Desse modo, contra uma escola de orientação livresca, clássica e autoritária, o ideário escolanovista contraponha a construção de uma pedagogia renovada e a criação de uma escola mais aberta, democrática e que colocasse no centro de suas ações os interesses das crianças.

A primeira escola desse tipo surgiu na Inglaterra em 1889 (GAMBI, 1999) e depois a experiência se expandiu para outros países europeus e para os Estados Unidos. No Brasil, as ideias da Escola Nova chegaram com mais intensidade por volta dos anos 20 do século passado, inspirando intelectuais, professores e gerando tentativas de reformas educacionais em Minas Gerais, Rio de Janeiro, Bahia e Ceará (NAGLE, 2001). No caso brasileiro, onde o maior expoente desse pensamento foi, sem dúvida, Anísio Teixeira, há uma particularidade: as reformas que se tentou fazer foram de caráter público, ao contrário das experiências nos outros países ${ }^{2}$.

O filósofo da educação John Dewey, nos Estados Unidos, maior expoente dessa corrente de pensamento e ação, deu origem a uma série de experiências educacionais baseadas na chamada "pedagogia ativa", base da Escola Nova. Essa pedagogia pregava que os professores deveriam utilizar os interesses das próprias crianças para orientá-las até o mais alto grau de em todas as matérias escolares (WESTBROOK, 2010).

Contudo, a despeito do sucesso em algumas escolas experimentais, o modelo da Escola Nova não conseguiu ser replicado em larga escala e - a despeito de algumas tentativas, incluindo o Brasil - não serviu como base para reformas concretas e duradouras dos sistemas públicos de ensino.

Os motivos do insucesso da Escola Nova - a despeito de suas inegáveis contribuições teóricas e práticas - geralmente são controversos, mas se aceitam

\footnotetext{
${ }^{2} \mathrm{O}$ caso do manifesto dos pioneiros da educação é exemplar no Brasil. Nele, há uma defesa do modelo de Escola Nova e da democratização da escola pública assinado por vários intelectuais importantes da época.
} 
como consenso: os altos custos de adaptação das escolas e da formação de professores; a ideia de que a escola poderia, de fato, ser um território neutro, um laboratório experimental, isolado da sociedade e, por fim, a opção por uma pedagogia que privilegiava mais o capital cultural dos grupos sociais mais ricos do que o capital cultural da população pobre.

O fato, porém, é que tanto a escola "tradicional” quanto a Escola Nova não estavam abertas a todos. Não eram escolas que incorporaram as grandes massas populares que apareciam como protagonistas dos tempos modernos. A escola moderna ainda não era uma escola de massas. Isso só ocorreria com fim da Segunda Guerra e com o apelo por mais participação e mais democracia.

\section{2}

\section{A "escola de massas"}

No período imediatamente posterior à Segunda Guerra consolida-se a crença de que a escola poderia e deveria ser uma instituição redentora dos males sociais, pois as desigualdades, vistas como "residuais" naquele momento, poderiam ser minimizadas ou até mesmo eliminadas com a expansão dos sistemas escolares. A aposta era a de que a escola conseguiria acolher as crianças que chegavam a ela de modo a dar a todas o mesmo tratamento, ampliando suas possibilidades existenciais e educacionais, revertendo, dessa maneira, as desigualdades sociais (KOSLINSKI; ALVES, 2012).

Primeiramente na Europa do pós-guerra e, depois, nos EUA, os investimentos públicos incrementam o processo de "massificação escolar" a partir do investimento nos sistemas públicos de ensino. Seabra (2009), ao analisar esse processo, discute como a escola pública,cada vez mais, passou a ser considerada como uma espécie "tábua de salvação" da sociedade, pois a ela caberia o papel de identificar/ formar os talentos necessários para a reconstrução econômica do mundo europeu do pós-guerra.

Nos Estados Unidos dos anos de 1950, por exemplo, ganhou força a teoria do capital humano desenvolvida por Theodore W. Schultz (SAUL, 2004) ${ }^{3}$. De acordo com essa teoria, a escola e a escolarização passam a ser um "ativo", um

\footnotetext{
${ }^{3}$ É bom que se diga que, na mesma medida em que a teoria foi bem aceita, sobretudo pelos economistas, também foi igualmente contestada por diversas correntes de educadores que a viam como reprodutora das ideias capitalistas.
} 
investimento que poderia render dividendos no futuro aos indivíduos mais escolarizados. A essa concepção se associa a ideia de produzir os "melhores" que, por sua vez, deveriam produzir uma sociedade também melhor.

No entanto, o que se percebeu, a partir das experiências concretas e dos resultados de desempenho escolar, foi que a escola de massas, ao tratar crianças de origens socioeconômicas desiguais da mesma maneira - porque acreditava que o indivíduo era o único responsável por seu desempenho e, assim, era preciso dar a todos o mesmo tratamento para que os verdadeiros talentos se sobressaíssem acentuou-se a separação entre ricos e pobres, brancos e negros, que já existia no tecido social, sobretudo, em países como os Estados Unidos.

Mesmo no interior da escola pública, que se pretendia, ao menos em tese, democrática ao dar a oportunidade de educação a todos, havia diferenças de desempenho entre crianças negras e brancas e entre ricas e pobres. Os resultados desiguais, com evidente vantagem para aquelas que frequentavam as escolas privadas e para as crianças brancas, fizeram com que a preocupação com as diferenças de desempenho escolar se acentuasse na década de 1960, no século passado (SEABRA, op. cit.) fortalecendo um movimento que vinha crescendo desde o fim da Segunda Guerra.

Até então, acreditava-se que o fenômeno da desigualdade dos desempenhos escolares se explicava pelas diferenças entre escolas e que os resultados se associavam aos inputs ou insumos escolares que eram determinantes para os resultados ou outputs (BROOKE, 2008).

Desse modo, alguns governos encomendaram estudos para avaliar o papel da escola. Era uma tentativa de compreender se ela, de fato, realizava um trabalho de "equalização" social e se poderia assumir a tarefa de alavancar o desenvolvimento dos países e das pessoas. Era o momento de saber se a ideia da igualdade de tratamento realmente beneficiava a todos da mesma forma e, ao mesmo tempo, tentar compreender o porquê das diferenças de desempenho tão díspares. Assim, nos anos 1960, junto com a expansão da escolarização, aumentou o número de pesquisas que se enquadravam no chamado "empirismo metodológico" (KOSLINSKI; ALVES, op. cit.). Esses estudos se desenvolvem a partir de pesquisas empíricas e de dados quantitativos. Foi a época dos grandes surveys. 
O estudo de maior impacto, tanto por seu caráter inovador quanto pelos dados que recolheu e pelas polêmicas que suscitou, foi sem dúvida o Relatório Coleman (BROOKE; SOARES,2008). O estudo coordenado pelo sociólogo estadunidense James Coleman, encomendado pelo departamento de Educação dos Estados Unidos, pesquisou dados de mais de seiscentos mil estudantes e de três mil escolas.

A premissa principal era a de que os "insumos escolares" fariam diferença nos resultados escolares, ou seja, escolas mais bem equipadas e com mais recursos - com melhores bibliotecas, melhores professores, laboratórios, equipamentos pedagógicos- poderiam ter maior impacto nos resultados de seus estudantes.Todavia, Coleman acabou por descobrir que as escolas estadunidenses não eram tão diferentes entre si como se pensava até então. Seus recursos, em termos de infraestrutura e recursos humanos, eram parecidos. Isso punha por terra a teoria e a crença bastante arraigadas de que os insumos escolares eram responsáveis pelas diferenças de desempenho.

Essa primeira conclusão, ou seja, a de que as escolas são muito parecidas em termos de recursos e, portanto, não é daí que nascem as desigualdades, gerou um bom debate no campo acadêmico e no âmbito dos governos. Porém, o que de fato tornou o relatório Coleman impactante foi a afirmação de que eram as condições de origem social dos estudantes as que mais determinam os resultados escolares. Foi posta em xeque a crença de que a simples expansão dos sistemas escolares promoveria mais igualdade de oportunidades e democratizariam a própria sociedade ao oferecer a todas as crianças o acesso à escola. As desigualdades escolares, que eram vistas como residuais e pouco determinantes para o desenvolvimento dos indivíduos, passaram a ser vistas de outro modo.

De maneira complementar, estudos como A reprodução: elementos para uma teoria do sistema de ensino (BOURDIEU; PASSERON,2008), de modo geral, demostraram que o tipo e a qualidade do capital cultural familiar produziam, em grande medida, o sucesso ou o fracasso das crianças nas escolas. Isso acontecia porque as famílias mais ricas geralmente têm acesso maior a bens, equipamentos e serviços que, de um modo ou de outro, são convertidos em bens e hábitos culturais valorizados pela sociedade e pelas escolas, em detrimento dos grupos populares, que não têm os mesmos recursos e possibilidades. 
Nesse sentido, Bourdieu e Passeron (ibid.) denunciam a violência simbólica contida nas ações pedagógicas escolares, que afirmavam uma cultura escolar mais próxima dos grupos sociais privilegiados, afastando-se da cultura dos grupos populares, origem da maioria das crianças que frequentava as escolas públicas.

Desse modo, a escola, ao privilegiar a cultura das classes sociais ricas, cumpria o papel de manter as desigualdades e de reproduzir as hierarquias socioeconômicas tal qual elas se davam fora de seus muros. A escola atuaria, assim, na legitimação das desigualdades, ao converter as diferenças sociais de origem em diferenças acadêmicas. De outro modo, a escola seria responsável por converter as desigualdades sociais em desigualdades escolares.

Os estudos do chamado empirismo metodológico, nos quais se encaixam os estudos citados de Coleman e Bourdieu, tiveram profundo impacto nas discussões relativas ao papel da escola e à sua eficácia como equalizadora social. Como vimos, havia, até então a crença, ou esperança, de que a escola pudesse ser uma instituição capaz de reverter as desigualdades sociais ao proporcionar igualdade de oportunidades a todos. Façamos, contudo, uma ressalva. As conclusõesdo relatório de Coleman, em conjunto com os outros estudos, como os de Bourdieu, por exemplo, foram traduzidas, muitas vezes, de forma apressada. O senso comum escolar traduziu as conclusões desses estudo sem uma assertiva, segundo a qual a escola não faria diferença na vida das crianças.

Trata-se, na verdade, de uma conclusão equivocada, já que o que a pesquisa de Coleman permitiu afirmar foi que as características escolares variavam muito pouco entre as escolas norte-americanas, não explicando, portanto, as significativas variações de resultados entre alunos de diferentes origens sociais, culturais e raciais.

Por seu turno, Bourdieu denunciou que a escola, ao contrário do que se queria, não era capaz de,isoladamente, reverter as desigualdades de origem social. Ela, na verdade, acabava por validar tais desigualdades ao transformar as desigualdades de origem em desigualdades escolares. Mas não se dizia que a escola não faria diferença alguma, pelo contrário, para os alunos pobres ela fazia diferença. Era importante para as crianças mais pobres estarem na escola, mesmo com todas as limitações apontadas anteriormente.

De todo modo, o fato é que, em reação crítica ao pessimismo e à perplexidade gerados pela divulgação dos resultados sobre o papel da escola nos 
anos de 1960 e 1970, houve um bom número de novos estudos que empreenderam novas pesquisas, com o objetivo de demonstrar a importância da escola e sua capacidade de fazer a diferença. Desse movimento, surgiu o que se convencionou chamar de movimento das "escolas eficazes" (BROKE; SOARES, op. cit.). Na próxima seção, observaremos mais de perto esse movimento e sua importância para o debate sobre a escola e a escolarização.

\section{3}

\section{As escolas eficazes: a escola faz diferença}

A partir da crítica ao Relatório Coleman ${ }^{4}$ surgem os estudos sobre eficácia escolar, cujo interesse principal é entender o que determinadas escolas, a despeito do peso das origens sociais dos alunos, estavam fazendo para impactar positivamente as trajetórias escolares. Abriu-se, assim, um novo campo de investigação, no qual se privilegia o estudo das ações empreendidas no âmbito das escolas para gerar efeitos positivos no aprendizado de seus alunos. Este campo envolve também a discussão da qualidade do ensino, relacionando-a a questões relativas à organização institucional e pedagógica das escolas.

Nesse processo, novos objetos de estudo, novas metodologias e conceitos foram criados para dar conta das mudanças de enfoque sobre o papel social da escola. Em termos de novas variáveis de investigação, merecem atenção as tomadas de decisão, tanto no nível escolar quanto no nível central; a avaliação de processos de mudanças na forma de organização das escolas e de suas salas de aula; e as condições favoráveis ou desfavoráveis para a implementação de programas e projetos de melhoria para produzir eficácia escolar. (BROOKE; SOARES, 2008)

Ao lado da inclusão dessas variáveis, houve a aplicação de novas metodologias de investigação, tais como: os estudos de caso, envolvendo escolas que obtinham sucesso escolar junto aos grupos sociais mais desfavorecidos; o acompanhamento da introdução de mudanças e inovações administrativas e

\footnotetext{
${ }^{4}$ Outras críticas foram feitas: quanto à escolha das variáveis, não necessariamente as mais importantes, mas as de mais fácil mensuração; as medidas de resultado apoiam-se quase que exclusivamente em testes padronizados de desempenho quando os resultados escolares não se referem apenas ao nível acadêmico; a ordem estatística, no que diz respeito à dificuldade de se distinguir com clarezaos efeitos das diferentes variáveis utilizadas, seja pelo efeito de covariação entre elas, seja pelos efeitos de interação ouagregação que não puderam ser devidamente distinguidos (BROKE;SOARES,2008).
} 
pedagógicas em determinados grupos de escolas; e a avaliação de programas que visavam melhorar o desempenho de alunos e professores. Em termos conceituais, o desafio foi transformar os aspectos escolares, que hipoteticamente se associavam para produzir melhor desempenho escolar, em categorias de análise que pudessem ser operacionalizas para, por sua vez, identificar as diferenças entre as escolas, que realmente produziam mais eficácia.

De modo geral, as pesquisas apontaram determinadas práticas desenvolvidas por escolas eficazes que poderiam ser consideradas fundamentais: o clima escolar; o melhor uso do tempo nas aulas, com ênfase acadêmica; as oportunidades de aprendizado criadas em sala de aula pelos professores; o papel da liderança do diretor; as expectativas dos professores; ensino e objetivos claros quanto ao que ensinar e como ensinar e, por fim, o envolvimento dos pais na educação escolar de seus filhos (ibid).

Esse último ponto, ou seja, o envolvimento dos pais merece destaque porque se sintoniza diretamente ao tema de nosso trabalho e contesta a compreensão hegemônica, que até esse momento se tinha sobre os responsáveis pelos alunos, que eram vistos como entes exteriores às escolas, ou seja, que eram compreendidos como estruturas que incidiam sobre a escola a partir das questões socioeconômicas e culturais, mas que não se comunicavam diretamente com ela ${ }^{5}$.

Nesse momento, as pesquisas sobre escolas eficazes abriram um novo caminho de investigação sobre as relações entre escolas e famílias. Pesquisas recentes têm apontado a importância das relações entre professores e responsáveis pelos alunos para o sucesso escolar das crianças dos grupos e classes populares. Seguramente esse é um dos temas que mais tem movimentado os debates nos âmbitos da Sociologia da Educação e da Sociologia da família.

\footnotetext{
${ }^{5}$ Nogueira (1998) ressalta que uma das marcas fundamentais dos primeiros estudos sobre o tema da desigualdade de desempenho nos anos de 1960 era a de que eles se interessavam pela relação educação/classe social, buscando explicações para as desigualdades nos resultados de desempenho. Outra característica marcante era que esses estudos se preocupavam com a "morfologia" da família, em termos de sua composição e características, mas não viam os processos escolares como legítimos objetos de investigação.
} 


\section{4 Consolidação de um novo campo de investigação na Sociologia da Educação}

Entre os anos de 1980 e 1990, há uma importante mudança teóricometodológica nas ciências sociais que alcança também a Sociologia da Educação (NOGUEIRA, 1998). Essa mudança tem a ver com novos modos de compreender as dinâmicas sociais e, sobretudo, com uma maior ênfase na relativa autonomia dos agentes sociais em suas ações. O olhar é transferido das macroestruturas para as microestruturas, com ênfase nas práticas pedagógicas cotidianas que constroem as relações nas escolas.

Essa abordagem iluminou uma série de novos objetos de estudo, tais como o currículo, a sala de aula e os estabelecimentos de ensino, e estimulou a adoção de novas metodologias baseadas em estudos etnográficos, observação-participante, histórias de vida, biografias escolares, entre outras. Nesse processo, surge um novo campo da Sociologia da Educação, dedicado ao estudo das trajetórias escolares dos indivíduos e das estratégias familiares para lidar com a educação escolar, sobretudo as de origem popular. Tal movimento gerou, também, um novo referencial de análise que "ambicionava ir além da já clássica sociologia da escolarização [...] tentando construir uma sociologia das escolaridades" (ibid., p. $50)$.

Para explicar essa mudança, a autora afirma que as transformações ocorridas na família e no pensamento sociológico permitem o estabelecimento de uma concepção, segundo a qual as "orientações familiares operariam como uma mediação entre, de um lado, a posição familiar na estratificação social e, de outro, as aspirações e condutas educativas, e as relações com a escolaridade" (NOGUEIRA, op. cit.).

Assim, as famílias deixaram de ser vistas, no âmbito da Sociologia da Educação, como apenas reflexos das classes sociais para passarem a ser enxergadas como mais autônomas frente às estruturas sociais e econômicas. Por outro lado, é interessante observar que, no âmbito familiar, as relações afetivas entre pais e filhos ganham outras dimensões na sociedade moderna. $\mathrm{O}$ filho passa a ser uma escolha, é fruto da vontade dos pais, não apenas uma imposição ditada por uma convenção social. Contribui para isso as mudanças de estatuto da criança nas sociedades democráticas, nas quais as leis contra o trabalho infantil, maus 
tratos e a obrigação da proteção por parte do Estado e da sociedade são garantias constitucionais.

Por sua vez, o filho deixa de ser uma "garantia dos pais na velhice", pois,nas sociedades modernas,os sistemas de poupança e previdência social dão conta disso. Definitivamente, ao menos para a maioria da população, os filhos passam a ser investimentos afetivos e motivo de orgulho familiar (ARIÈS, 2000).

De acordo com Nogueira (op. cit.), tal mudança de concepção sobre o filho faz com que as famílias passem a se preocupar ainda mais com as condições de inserção da prole na sociedade, o que, nas sociedades modernas, se realiza pela intermediação da escola e dos títulos escolares por ela distribuídos, ou seja, do capital cultural institucionalizado, para usarmos um termo de Bourdieu (BONAMINO et al, 2010) ${ }^{6}$. Portanto, é nesse capital institucionalizado que residiria a esperança das famílias de manter ou ampliar suas inserções em postos mais altos e valorizados na escala socioeconômica.

Daí a importância atribuída à escolarização ter aumentado tanto: a escola se transformou em um espaço de legitimação individual e de distribuição de atributos que determinam o valor dos indivíduos dentro de sociedades cada vez mais competitivas e hierarquizadas (BOURDIEU, 1998).

Assim, a escolarização de mais longa duração e os estudos de mais alto valor social passam a ser estratégias das famílias, principalmente das famílias de classe média que possuiriam melhores condições para entender o "jogo escolar" e dele se beneficiar.

O fato, porém, é que com o advento da escola de massas outro tipo de família, a família de origem popular, também ingressa no jogo escolar. Embora não compreenda as regras desse jogo o suficiente, essa família vai percebendo, ao longo do tempo, o quanto a escola poderia ser importante para seus filhos. A partir daí, o tema das relações entre escolas e famílias de origem popular ganha relevância, pois a presença dos filhos dos trabalhadores nas escolas impõe novos desafios a todos, inclusive ao campo da Sociologia da Educação.

\footnotetext{
${ }^{6} \mathrm{O}$ capital institucionalizado pode ser considerado como uma das formas de capital cultural incorporado, objetivado e institucionalizado - e se refere aos títulos e diplomas que o indivíduo obtém durante sua vida escolar. Ele define, em grande medida, em que condições os indivíduos ingressam e avançam ou não no mercado de trabalho.
} 


\section{5 \\ Escolas públicas e famílias populares: uma relação conflituosa}

No momento em que a escola se tornou mais acessível a um número maior de crianças e famílias, novos estudos sobre as relações entre as escolas públicas e as famílias populares passaram a demonstrar o quão difícil e desigual foram, e ainda são, tais relações (BURGOS, 2010). A inclusão das crianças pobres nas escolas trouxe consigo uma série de questões para as quais a escola pública não estava preparada, fazendo com que, ainda hoje, as relações entre os profissionais da escola e as famílias populares sejam carregadas de conflitos e desencontros, sobretudo quando se considera o peso da origem familiar dos alunos e os territórios em que estes habitam.

Uma das razões mais fortes desses conflitos tem origem na disparidade entre o capital cultural valorizado pela escola e o capital cultural mobilizado pelas famílias populares. Como bem demonstraram os estudos citados acima, o ambiente escolar reproduz condições que favorecem o capital cultural dos estratos sociais dominantes e, no mesmo processo, desconsidera as práticas dos grupos populares que estão distantes do capital cultural valorizado e tido como o melhor.

Brandão, Mandelert e Paula (2005), por exemplo, pesquisaram escolas privadas tidas como de excelência na cidade do Rio de Janeiro e corroboraram os resultados obtidos pelos estudos de Bourdieu, ao colocarem em evidência a importância das práticas familiares dos estratos sociais mais elevados para o sucesso escolar de seus filhos. Essas práticas vão ao encontro do que a escola espera do "mundo natal" dos alunos, ou seja, uma socialização primária que se coadune com o tipo de capital cultural tido como legítimo e que possibilite uma espécie de continuidade entre a casa e a escola. Isso favorece a chamada "circularidade virtuosa", que acontece quando o perfil das famílias e dos estudantes se articula com a qualidade e a experiência dos profissionais das escolas e produz resultados positivos em termos de aprendizagem e desempenho escolar (BRANDÃO; PAES, 2011).

A pesquisa de Brandão, Mandelert e Paula, permite verificar, ainda, que a relação entre alunos e professores nessas escolas é considerada boa pela maioria dos envolvidos no processo educativo (pais/responsáveis, professores, diretores e

\footnotetext{
${ }^{7}$ Da expressão usada por Bourdieu que pode ser definido com o "ambiente de socialização primária" ocorrido no seio familiar.
} 
os próprios alunos), o que evidencia um "clima escolar" propício para o bom aprendizado e que cria, por conseguinte, altas expectativas de aprendizado dos professores com relação a seus alunos.

Nesse sentido, o quadro apresentado pelas autoras revela que os alunos adquiriram, no convívio familiar, autodisciplina, valorização do dever de casa e da leitura, além de experiências culturais relevantes, como viagens ao exterior, frequência ao cinema e acesso à tecnologia, o que está de acordo com as práticas esperadas pelas escolas e pelos professores. Seguramente, a construção de um alto capital cultural sintonizado com o que a instituição escolar julga ser adequado, favorece as crianças oriundas dos estratos sociais mais elevados.

Poderíamos dizer, ainda, que a lógica de socialização das famílias mais ricas está em sintonia com as lógicas escolares e isso, não temos dúvidas, é fundamental para o sucesso escolar das elites. Estudando o espectro social oposto, Daniel Thin(2006) reconhece que é preciso observar que as camadas populares enfrentam dificuldades diante da escolarização e isso certamente tem a ver com o capital cultural das famílias, embora as dificuldades não se resumam apenas a esse aspecto.

Os problemas das crianças de origem popular diante da escola estão relacionados, segundo o autor francês, à antinomia entre a lógica socializadora de suas famílias e a lógica socializadora da escola.

Para compreender as relações entre as famílias populares e a escola, [...] [é preciso] levar em conta o fato de que essas relações colocam em jogo maneiras de estar com as crianças, maneiras de examinar as aprendizagens, maneiras de comunicar, ou, ainda, maneiras de regulamentar os comportamentos infantis e juvenis. [...]. Não é, portanto, somente o capital cultural ou o capital escolar que estão em jogo; é o conjunto das práticas socializadoras das famílias que estão implicadas nas relações entre os pais e os professores, e essas práticas devem ser compreendidas por sua distância do modo escolar de socialização, mais do que pelo capital escolar dos pais (THIN, 2006, p. 50).

Desse modo, as práticas familiares das camadas populares estão em desacordo com o que o universo escolar considera como aceitável e desejável. Isso engloba o comportamento, a linguagem, o uso do tempo e os símbolos que são incorporados pelas crianças dos grupos populares. O universo popular de onde vem a maioria dos estudantes da escola pública simplesmente não se coaduna com o universo escolar.

Um bom exemplo dessas lógicas socializadoras antinômicas envolve a relação com o tempo. Enquanto, na escola, o tempo da aprendizagem e o tempo da 
prática são separados, no interior das famílias populares não existe tal separação e a aprendizagem é realizada de forma eminentemente prática no cotidiano. Tempo e espaço estão intrinsecamente unidos e a serviço da experiência empírica (THIN, op. cit.).

Obviamente, essa contradição, entre o vivido em casa e o vivido no espaço escolar, trará consequências para as crianças de origem popular. O espaço escolar privilegiará um determinado modo de ser e de comportar-se que não é dominado pelas crianças das famílias populares, bem como haverá uma dificuldade grande dos pais dessas crianças para acompanhar a vida escolar de seus filhos. Esta visão é corroborada por Charlot (2000) quando discute a ideia do fracasso escolar nos grupos populares e refuta a concepção, muito difundida, de "carência" ou da mera deficiência cultural dos estudantes pobres como explicação para o insucesso escolar.

Nessa linha, Vorraber (2002) afirma que a ideia da carência cultural como causa do fracasso escolar não reconhece que os setores populares vivem sob uma relação de dominação social e, por conta disso, seus códigos, práticas e símbolos não são reconhecidos como legítimos. De acordo com a autora:

Quando alguém é descrito, explicado, em uma narrativa ou discurso, temos a linguagem produzindo uma 'realidade', instituindo algo como existente de tal ou qual forma. Neste caso, quem tem o poder de narrar o outro, dizendo como está constituído, como funciona, que atributos possui, é quem dá as cartas de representação, ou seja, é quem estabelece o que tem e o que não tem estatuto de realidade. (VORRABER, 2002, p. 40.)

Portanto, reconhecer que o capital cultural das famílias pobres, ao não ser valorizado pela escola, coloca os estudantes de origem popular em desvantagem diante da instituição escolar é significativo. Contudo, é preciso observar que a questão é mais complexa, pois ela também envolve o reconhecimento de que a lógica socializadora dos setores populares e a lógica socializadora da instituição escolar são antinômicas e baseadas em uma relação de hierarquização cultural e desigualdade social. Isso faz com o universo escolar se afaste do universo de seus alunos criando uma relação desigual e conflituosa. 


\section{6 \\ O discurso da desestruturação familiar}

Uma das consequências da relação desigual entre as lógicas de socialização familiares e escolares é a atual consolidação do discurso "da falta de estrutura familiar" dos estudantes de origem popular (BURGOS, 2009). Essa suposta "desestruturação" familiar seria a causa dos principais problemas de aprendizado e do comportamento inadequado na escola o que, consequentemente, impediria às crianças oriundas dos meios populares de terem desempenho escolar satisfatório.

Obviamente, tal discurso não é inteiramente novo, pois se configura como mais uma variante de uma cadeia de explicações para o fracasso das crianças pobres, que vem sendo reelaborada a partir dos antigos discursos sobre as deficiências das crianças de origem popular, tais como, deficiências culturais, de saúde ou de capacidade de aprendizagem. (PATTO, 1992).

Um bom exemplo do discurso da desestruturação familiar aparece no estudo dos pesquisadores Marcelo Burgos e Ângela Paiva (2009), realizado com professores e diretores de escolas localizadas em uma favela da zona sul da cidade do Rio de Janeiro. Nessa pesquisa, eles trazem relatos das representações que alguns profissionais da educação têm a respeito do universo de seus alunos, como se pode observar nos trechos abaixo.

Gente é outro mundo! É outro código, são outros valores. As relações sociais tecidas aqui são permeadas por alguma coisa, pelo Estado, por uma estrutura formal. Lá não existe isso. Lá existe outra coisa que a gente aqui não sabe direito o que é. Eu não vou dizer se é ruim, se é bom, se é o contrário, entendeu? Alguma coisa que eu não consigo, que eu vejo como diferente, mas eu não consigo ainda qualificar essa diferença (Professora da escola II. BURGOS; PAIVA, 2009, p. 66).

Não é só dificuldade de aprendizado, não. Tem muito problema mesmo de relacionamento familiar, porque a gente tem muito drama aqui. A qualidade de vida que eles têm... a gente não passou pela metade do que eles passam. É coisa de botar a mão na cabeça e perguntar como é que essa criança ainda consegue vir para a escola, fazer um dever, fazer prova. Há imensos dramas aqui (Diretora da escola II. Ibid., p.66).

É interessante perceber que os professores compreendem o universo familiar de seus alunos como diferente e que, a despeito da solidariedade manifestada por alguns, eles enxergam essa diferença como uma barreira ao aprendizado. Isso, mais uma vez, reforça a distância entre escolas públicas e famílias populares. Fica claro nos depoimentos de professores e diretores que a escola e seus agentes mantêm distância e desconhecimento não apenas do mundo familiar de seus 
alunos, mas também da própria vizinhança, ou seja, das comunidades/favelas no entorno da escola.

Nessa mesma pesquisa, Burgos e Paiva (op. cit.) apresentam uma série de dados que desafiam afirmações tidas como verdadeiras pelo senso comum, que acabam ratificadas pelos profissionais da escola e pelas políticas públicas. Essas afirmações acabam gerando uma representação negativa das famílias pobres, o que, por sua vez, pode transformar tais representações em práticas discricionárias mais ou menos veladas, que podem afetar o desempenho das crianças.

A pesquisa apresenta conclusões interessantes decorrentes da análise crítica das afirmações que compõem um determinado discurso sobre as famílias populares, que as culpa pelos problemas de aprendizado e desempenho dos estudantes. Isto se expressa em afirmações, por exemplo, como as que caracterizam as famílias populares como omissas no que tange à educação escolar de suas crianças, ou, ainda, como responsáveis por uma suposta falta de comprometimento com a escola e com a escolarização de seus filhos.

Desconhecer o universo dos alunos certamente reforça uma visão parcial e incompleta do mundo que os socializam, ou seja, de sua família e de seu território. Essa visão incompleta dificulta sobremaneira a compreensão de questões exteriores que afetam diretamente o trabalho e as relações nas unidades escolares. Além do desconhecimento das famílias dos alunos, há também um desconhecimento ou conhecimento superficial sobre o território onde a escola se situa e desenvolve seu trabalho. Por isso, estudos mais recentes têm incorporado a dimensão territorial, o bairro, a vizinhança, ou seja, o entorno escolar como aspectos fundamentais para a compreensão das relações escola-família.

Deste modo, compreender o que a literatura chama de "efeito-vizinhança" passa a ser fundamental para se pensar o papel da escola nas favelas e nos bairros pobres, pois é desses territórios que provêm, em grande medida, os alunos e alunas que frequentam a escola pública.

No próximo capítulo, apresentaremos algumas iniciativas conhecidas como Políticas de Educação Prioritárias, que partem da premissa de que é preciso observar as caraterísticas específicas dos alunos que moram em determinados territórios das cidades. Geralmente esses territórios têm baixos indicadores socioeconômicos e concentram outros problemas sociais consideráveis. Isso, 
segundo os formuladores de tais políticas, justificaria um tratamento diferenciado o público atendimento pelas escolas públicas nesses territórios. 


\section{3 \\ As Políticas de Educação Prioritária (PEP)}

No conjunto de favelas da Maré, localizado na região da Leopoldina, na cidade do Rio de Janeiro, funciona, desde 2010, o PEA/BE. De acordo com os documentos que lhe dão base, o programa tem como uma de suas finalidades desenvolver ações em algumas escolas públicas da região, no sentido de melhor a qualidade da educação.

De iniciativa da Secretaria Municipal de Educação do Rio e Janeiro (SME$\mathrm{RJ})$, o programa teve ainda como um de seus projetos mais importantes o Bairro Educador (BE). Este projeto, que funcionou até o ano de 2013, tinha como foco principal a promoção de uma maior aproximação entreas escolas locais, as famílias dos estudantes destas escolas e o território onde as instituições se localizam.

As ações desenvolvidas no âmbito do PEA/BE podem ser enquadradas no que a literatura chama de Políticas de Educação Prioritária (PEP). Tais políticas procuram realizar uma "discriminação positiva" dos estudantes que se encontram em dificuldades nas escolas públicas - principalmente as localizadas em territórios mais pobres da cidade - ao destinar recursos adicionais, financeiros e humanos, além de projetos e ações suplementares de apoio.

Por conta dessa "filiação" do PEA/BE, nos propomos a observar mais de perto algumas inciativas dentro e fora do Brasil, que podem ser enquadradas como PEP. Tais políticas, ao menos em suas primeiras versões, surgiram como forma de combater, por meio da educação, as desigualdades sociais presentes em determinados territórios.

A ideia era a de que, a partir da escola e da educação escolar, se construísse uma rede local de agentes sociais, pessoas e grupos que potencializasse os efeitos da educação no território e, ao mesmo tempo, que os agentes integrantes dessas redes locais contribuíssem com suas experiências e recursos para que a escola pudesse alcançar seus objetivos pedagógicos.

Desse modo, as PEP procuram incentivar uma maior abertura da instituição escolar para o território e para seus moradores. Procuraram, em síntese, fazer com que a escola ganhasse uma "centralidade" na vida comunitária e passasse a ser um ponto de referência para o desenvolvimento sociocultural local. 
Na próxima subseção aprofundamos o conceito de PEP, utilizando alguns exemplos de inciativas desse tipo, tendo como referências principais as experiências francesa e portuguesa. Mais especificamente, apresentamos algumas iniciativas que inspiraram o PEA/Bairro Educador, como o Programa "Mais Educação" de inciativa do governo federal, no Brasil, as Zonas de Educação Prioritária (ZEP), na França, os Territórios Educativos de Intervenção Prioritária (TEIP), em Portugal e as Cidades Educadoras, na Espanha.

\section{1}

\section{Das políticas compensatórias às Políticas de Educação Prioritárias (PEP)}

Nos anos 1960, nos Estados Unidos, diversas ações governamentais se encaminharam para a criação de programas educacionais que procuravam "compensar" o que era entendido como certas "carências culturais" trazidas à escola pelos estudantes dos bairros pobres, negros ou de culturas diferentes da cultura branca estadunidense.

Assim, as primeiras políticas públicas "compensatórias" partiam da premissa de que determinados grupos sociais fracassavam na escola por conta de suas carências culturais e sociais. O aluno que apresentava desempenho insuficiente na escola acabava sendo culpado, juntamente com sua família, pelos seus resultados escolares porque se acreditava que ele, justamente por conta de sua condição de pobreza e distanciamento do mudo letrado, não possuía as características necessárias para atingir o sucesso escolar. $\mathrm{Na}$ verdade, essa perspectiva e a consequente criação de políticas compensatórias estão relacionadas com o processo de entrada em massa na escola das crianças pobres que antes não tinham acesso à escolarização formal.

O processo de “massificação escolar", acelerado principalmente nos anos 60 e 70 do século passado, tem relação com a própria reestruturação do sistema de produção capitalista e com as transformações sociais decorrentes.As empresas precisavam - a partir da modernização de sua produção, com o incremento dos sistemas informatizados, cada vez mais sofisticados, e o aumento da competição por mercados globalizados - de mão-de-obra mais qualificada e apta para manusear as novas tecnologias, o que, por sua vez, só seria possível se o sistema escolar conseguisse formar trabalhadores capazes de responder às novas 
exigências desse novo mundo do trabalho. Obviamente, esse processo é bem mais complexo do que pode parecer e as relações entre sistema econômico e sistema educacional não são lineares. No entanto, o fato é que inegavelmente as mudanças pelas quais passa o sistema de reprodução da vida material afetam o sistema educacional e outras áreas da vida social.

Acrescentemos a esse contexto o fato de que grupos e movimentos sociais progressistas, muito ativos nos anos de 1960, como é o caso dos movimentos em prol dos direitos civis nos EUA, também reivindicavam direitos para as populações mais pobres, dentre os quais o direito à educação para todos.

Assim, programas como os Head Start e Title $I^{8}$ foram lançados, nos anos de 1960, (CHISTÓVÃO; BRANCO, 2014), nos Estados Unidos, como maneira de ajudar a combater a evasão escolar, enfrentar o fracasso escolar e também melhorar a qualidade da educação. Tais programas se inscrevem no contexto estadunidense da chamada "guerra contra a pobreza", vista como a causa das "carências" dos grupos mais pobres da população e de seu suposto "atraso".

O que guiava as ações das políticas compensatórias estadunidenses era a ideia de "dar mais a quem tem menos". Acreditava-se que era preciso investir em insumos escolares e disponibilizar recursos extras para aqueles estudantes que precisavam de ajuda para superar sua situação de insucesso escolar.

Desse modo, através da discriminação positiva, ou seja, do reconhecimento de que determinados grupos de estudantes precisavam receber mais atenção e investimentos do que outros, os defensores das políticas compensatórias esperavam "equilibrar" o jogo escolar (MOIGNARD, 2014) em favor dos mais "fracos". Assim, a oportunidade seria dada a todos aqueles que precisavam da escola e ela, a escola, poderia cumprir o papel de combater as desigualdades escolares e sociais.

O fato, porém, é que os primeiros programas compensatórios não conseguiram cumprir seus objetivos e fracassaram apesar dos grandes investimentos feitos. $\mathrm{O}$ insucesso escolar continuava alto e poucas mudanças reais foram percebidas nos grupos mais pobres da população para quem se destinavam os programas educacionais compensatórios.

\footnotetext{
${ }^{8}$ Programas educacionais gerenciados pelo Estado que destinam recursos para atender crianças em idade pré-escolar (Head Star) e de apoio a crianças com dificuldades escolares ou atraso (Title I).
} 
As críticas encetadas às primeiras políticas compensatórias e de "discriminação positiva" apontavam para o fato das mesmas não levarem em conta a relação entre a educação escolar e as questões socioeconômicas geradoras das desigualdades estruturais, que são construídas além dos muros escolares. Dito de outro modo, não se fazia a necessária correlação entre o que acontecia nas escolas e as transformações pelas quais passava a sociedade estadunidense, sobretudo, o processo de ampliação das desigualdades socioeconômicas.

$\mathrm{Na}$ agenda política da época, o "combate à pobreza" deveria ser feito pela via da escola porque se acreditava que a falta de uma melhor instrução era a responsável pela situação de penúria material e de "déficit cultural” das crianças e famílias pobres.

Nesse mesmo momento, sob a influência do impacto do Relatório Coleman, dos primeiros estudos sobre escolas eficazes, dos movimentos pelos direitos civis e da reorganização do próprio sistema de produção capitalista, surgem as primeiras Políticas de Educação Prioritárias (PEP).

As PEP passaram a orientar as ações educativas desenvolvidas por governos de vários países diferentes e adotaram a ideia de "dar mais a quem tem menos", com base no conceito dos déficits culturais e da inclusão da temática territorial em suas ações compensatórias. A crença principal dos governos que passaram a adotar as PEP era a de que, por meio da intervenção escolar, seria possível se interferir nas questões sociais e territoriais mais amplas.

$\mathrm{Na}$ próxima seção abordaremos uma das primeiras iniciativas desse tipo. Trata-se do estabelecimento das Zonas de Educação Prioritárias na França e do seu funcionamento. Essa é uma das primeiras experiências no quadro das PEP e uma das que mais influenciou o desenvolvimento de outras políticas semelhantes no mundo.

\subsection{1}

\section{A ZEP na França}

Em 1981, na França, foram criadas as Zone d'ÉducationPrioritaire (ZEP) durante o governo do socialista François Mitterrand e de seu ministro Alain Savary. Tal iniciativa fora tomada a partir do reconhecimento de que determinados alunos e grupos de alunos conviviam com histórias de alto fracasso escolar. A maioria deles se concentrava em territórios pobres de Paris e pertencia 
a famílias igualmente pobres que, frequentemente, eram pouco escolarizadas. Em razão disso, o sistema escolar francês passou a ter uma ação direcionada a escolas e grupos de determinados territórios identificados como mais "problemáticos" do ponto de vista dos indicadores educacionais e sociais.

O modelo de PEP francês se inspirou no programa inglês Educational Priority Areas, de 1968. Este modelo também priorizava o investimento de recursos e ações diferenciadas em áreas específicas de Londres.

A ZEP passou a ser uma das ações mais importantes da história educacional francesa e serviu de inspiração para outras PEP na Europa. Ainda hoje, quase $20 \%$ do sistema educacional francês funcionam a partir dessa experiência, o que representa uma parcela considerável de escolas, professores e estudantes.

De uma maneira geral, as ZEP seguem as três premissas presentes nas PEP relativas à ação sobre: a) a população vista como vítima do fracasso escolar; b) os territórios onde vive a população considerada prioritária, e; c) os estabelecimentos de ensino e redes que atendem a essa população (ROCHEX, 2011). A ideia dos formuladores da ZEP foi a de que as políticas de incentivo e de discriminação positiva fossem aplicadas nas "zonas", isto é, em territórios e escolas que atendiam ao público mais afetado pelo insucesso escolar, justamente para "dar mais a quem tem menos".

A criação das ZEP e sua política de discriminação positiva é um fato da maior relevância na história da escola francesa, já que vai contra um dos pilares da escola da Terceira República francesa, justamente a que preconizava o tratamento igual para todos, tendo a meritocracia como condição para o avanço e o sucesso escolar.De todo modo, vencidas as resistências iniciais e as muitas questões colocadas pelos professores, as ZEP englobaram 10\% das escolas francesas já em 1981, passando e mantendo-se em 20\% a partir de 2006 (BROCCOLICHI, 2014).

Cada "Zona de Educação Prioritária" demarcou um território escolhido pela administração central, no qual haveria sempre duas escolas de ensino fundamental II, outras escolas de ensino fundamental I e escolas de educação infantil. Essas escolas receberiam recursos adicionais da administração pública e teriam liberdade para criar ações próprias com o objetivo de combater o fracasso e a evasão escolar e de melhorar a qualidade da educação. As escolas deveriam, ainda, desenvolver parcerias com instituições e associações locais que pudessem ajudar no desenvolvimento das ações educativas. 
Segundo Broccolichi, os critérios para escolher e constituir uma ZEP mudaram muito desde 1981. Atualmente, o mais importante tem sido o nível educacional dos pais dos alunos e sua profissão, sendo o critério de renda o segundo em prioridade.

De acordo com o pesquisador francês, o critério da escolaridade dos pais é mais forte porque pesquisas na França têm demonstrado que é esse indicador o que mais contribui para o sucesso ou para o fracasso escolar das crianças. Pais mais escolarizados têm mais chances de acompanhar e apoiar melhor a escolarização de seus filhos. Eles, por exemplo, são os que mais têm condições de ir à escola e conversar com os professores com mais frequência porque conseguem entender melhor a dinâmica escolar.

Pais menos escolarizados geralmente têm mais dificuldades de acompanhar seus filhos, o que os faz menos presentes na escola muitas vezes por não se sentirem adequadamente preparados para conversar com os professores, por ter receio de não compreender o que é dito ou simplesmente por acreditar que seus filhos estão em "boas mãos" no que se refere ao processo de escolarização.

As ZEP são formadas por uma espécie de consórcio escolar e de outras instituições, como associações locais e órgãos das prefeituras, que definem de maneira autônoma como será feito o combate à evasão e ao fracasso escolar. Não se pode esquecer que as ZEP também se apresentam como instrumentos de melhoria do território onde elas se constituem, pois, uma das marcas desse tipo de política é justamente tentar interferir positivamente nos indicadores sociais através da escola.

Após trinta e seis anos de existência do programa, muitos estudos foram produzidos a partir da experiência das ZEP e muitas críticas também foram feitas. A primeira, comum em outras PEP, é a de que há uma variação grande de resultados entre as ZEP, o que não permite apontar com clareza as razões do sucesso ou do fracasso da experiência.

Essa variação pode ter a ver com muitos fatores, entre os quais a significativa dependência da ação de indivíduos em detrimento de processos institucionalizados. Segundo Broccolichi (op. cit.), isto significa que, quando determinados profissionais da escola se colocam como "defensores do programa" e decidem fazê-lo funcionar, há uma forte tendência de se atingir determinados 
objetivos com sucesso. Ao contrário, quando os profissionais da escola não "abraçam a causa", as chances de sucesso diminuem drasticamente.

É sabido, por exemplo, o papel importante que a liderança dos diretores de escola tem em qualquer ação que se pense nas escolas (BROOKE, SOARES,op. cit.). Assim, presume-se que se alguns diretores, mesmo com todas as dificuldades, decidem que querem realmente fazer o programa acontecer, e para isso, mobilizam e motivam suas equipes, certamente o sucesso fica mais fácil de ser atingido.

Obviamente, não podemos definir o sucesso ou fracasso de uma PEP apenas pela participação ou não de um indivíduo, mas é preciso levar em conta que, quando os processos institucionais, as regras, a coerência dos programas e os recursos disponibilizados são insuficientes, abre-se espaço para que as intervenções particularizadas ganhem maior relevância.

Por outro lado, muitas escolas não querem fazer parte das ZEP. Isso porque não querem sofrer com o estigma de serem vistas como escolas "ruins e problemáticas". O medo das equipes escolares é que os pais não matriculem seus filhos e procurem outras escolas próximas. Muitos alunos e suas famílias, de fato, fogem das escolas que têm o selo ZEP justamente por não quererem correr o risco de serem taxados como alunos "problemáticos" ou vistos como difíceis.

Outra questão importante é que, quando foram pensadas, as ZEP estavam inseridas em uma ação mais ampla de iniciativas do Estado denominadas de "zonas urbanas sensíveis" (ZUS). A ideia era integrar ações nos campos da saúde, cultura, habitação e educação e somar esforços para mudar a realidade dos territórios ZEP. No entanto, na maioria dos casos, isso não teve efeito e a fragmentação das ações continuou a ser a tônica o que, de alguma maneira, contribuiu para o insucesso de muitas ZEP.

Outra questão levantada pelos críticos das ZEP é sobre a necessidade de combater as desigualdades sociais e escolares, adotando-se um recorte territorial. Segundo Rochex (op. cit.) muitos formuladores de políticas públicas defendem que a abordagem adotada deveria ser outra, deveria ser uma abordagem individual. Assim, ao invés de se transferir recursos para as ZEP e para os estabelecimentos de ensino, o melhor seria investir diretamente no aluno com dificuldades, esteja ele onde estiver. 
Segundo os defensores dessa tese, isso evitaria a estigmatizarão de determinados territórios e também das escolas que fazem parte da ZEP e, ao mesmo tempo, se tornaria mais eficaz pelo fato de se investir diretamente em quem mais precisa.

De nossa parte, acreditamos que pode acontecer uma estigmatizarão das crianças e de suas famílias se o investimento das ZEP passar a ser feito diretamente nos indivíduos. A ideia de sucesso ou fracasso escolar é relacionada ao indivíduo, retirando do sistema escolar e, por conseguinte, do sistema socioeconômico quaisquer responsabilidades.

Por outro lado, algumas dificuldades se colocam no caminho de uma solução "individualizada" para as ZEP. Por exemplo, quais seriam os critérios de entrada e de saída do programa? Como acompanhar cada caso? Hoje, estima-se que as ZEP atendem quase 1,8 milhões de estudantes franceses (BROCCOLICHI, op. cit.).

Seja como for, as posições acima acompanham a própria evolução dos debates sobre o sentido da escola e da escolarização nas sociedades contemporâneas. As próprias PEP, como é o caso das Zonas de Educação Prioritárias francesas, sofreram muitas mudanças. Mais adiante, veremos mais detidamente como isso se deu e como influenciou as novas gerações de PEP, incluindo as brasileiras.

Antes, porém, é preciso que vejamos mais de perto a experiência dos Territórios Educativos de Intervenção Prioritária (TEIP) desenvolvidos em Portugal. Esse programa, certamente, foi o que mais inspirou as iniciativas brasileiras, pelo menos no caso do PEA/BE. Daí sua importância para este trabalho.

\subsection{2}

\section{A TEIP em Portugal}

A política de discriminação positiva Territórios Educativos de Intervenção Prioritária (TEIP) em Portugal foi instituída em 1996, inspirada na experiência francesa das ZEP. Já no primeiro ano, foram incluídos ao programa trinta e cinco agrupamentos escolares na grande Lisboa e na cidade do Porto. Dez anos depois, houve uma reformulação do programa (TEIP 2) e foram incluídos mais vinte e quatro agrupamentos, número que aumentou em 2008, com a entrada de mais 
quarenta e nove agrupamentos escolares (TEIP 3). Hoje, no total, a TEIP atende a cento e cinco agrupamentos escolares o que corresponde a $10 \%$ de professores, alunos e escolas do ensino básico em Portugal (CANÁRIO, 2004).

Tal qual a ZEP francesa, a TEIP procura olhar para determinados territórios da cidade considerados "degradados ou marginalizados" com uma série de objetivos, tais como melhorar a qualidade da educação, combater o fracasso escolar, ajudar os alunos a entrar em condições melhores no mercado de trabalho, e fazer com que a escola seja uma espécie de "elemento central da vida comunitária”(DGIDC/MINISTÉRIO DE CIÊNCIA E EDUCAÇÃO, 2012). Para tanto, as escolas que compõem uma TEIP devem se articular e coordenar, para o alcance desses objetivos, uma série de parceiros locais que precisam agir em conjunto para promover melhorias na educação e nos indicadores sociais e culturais do território.

A definição dos territórios onde foram constituídas as TEIP é controversa e varia de uma região à outra, como aponta relatório realizado pelo Centro de Investigação e Estudos de Sociologia (CIES) e pelo Instituto Universitário de Lisboa (ISCTE-IUL). Esse relatório, encomendado pelo governo português, faz uma avalição da TEIP 2, a partir da comparação entre sete Territórios Educativos de Intervenção (CIES; ISCTE, 2012).

De acordo com as conclusões da equipe de avaliação, há territórios que englobam agrupamentos compostos por apenas duas escolas e outros compostos por mais de oito escolas que, por sua vez, nem sempre correspondem a uma região administrativa específica como um bairro, por exemplo. Isso porque a própria rede de escolas em Portugal nem sempre obedece a critérios bem definidos que demarquem o território administrativo de pertencimento da escola.

Assim, o critério definidor de uma TEIP é que elas precisam atender a escolas que trabalham com populações residentes em territórios pobres e com um contingente de crianças em idade escolar em risco de abandono e fracasso.

A constituição das TEIP, à semelhança da ZEP francesa, é feita a partir de uma "escola sede", geralmente de $2^{\circ}$ ou $3^{\circ}$ ciclo, e de outras escolas do $1^{\circ}$ ciclo e jardins de infância que ficam no mesmo território. Desse modo, tem-se a formação de uma espécie de "aliança" entre as escolas, com a inclusão de outros parceiros locais que podem ajudar a promover as atividades que envolvam elementos territoriais nas discussões educacionais. 
Para a constituição da TEIP existe a obrigação de se elaborar uma espécie de plano de ação local a ser aprovado pela administração central. Na elaboração do plano, é recomendado que a TEIP faça um diagnóstico da população a ser atendida para que suas ações atendam às reais demandas locais. Espera-se, com isso, promover a integração entre as escolas, a população e o território, partindo sempre das demandas e anseios locais.

Cada unidade escolar deve ter seu próprio planejamento e este deve estar em conformidade com o plano mais geral da TEIP. O que se espera é que as escolas de uma mesma TEIP possam, assim, coordenar suas ações, potencializando-as. Com isso, a escola poderia vir a ser um centro ou "o centro"- como apresentado nos objetivos da TEIP - de articulação e promoção de crescimento sociocultural do próprio território, fazendo com que, por meio da educação e da articulação dos parceiros locais, houvesse uma intervenção positiva em outras áreas da vida local.

Os projetos pedagógicos dos agrupamentos que devem receber apoio das TEIP, geralmente, incluem uma maior diversificação do currículo escolar, com atividades que vão além do currículo tradicional e incluem ações inovadoras, tais como clubes de leitura, oficinas pedagógicas, jogos, "olímpiadas" de matemática, competições estudantis e orquestras musicais, entre outras (ibid.). O objetivo manifesto é o de que as crianças passem a gostar mais da escola e que isso ajude a diminuir a evasão e a reprovação.

Outra ação importante é a criação de dispositivos de acompanhamento mais individualizados dos alunos. Aqueles com maiores dificuldades de aprendizagem, com necessidades educativas especiais, de origem cigana e de outras nacionalidades que não a portuguesa, passam a receber atenção e suplementos diferenciados nas escolas.

Para tanto, há um reordenamento do funcionamento das equipes escolares, a contratação de novos profissionais, que não se resume a apenas mais professores, e uma intensificação do reforço escolar. A ideia continua sendo a máxima de "dar mais a quem tem menos", como nas ZEP francesas.

Quando observamos os resultados das TEIP, verificamos que, de modo geral, os pesquisadores concordam que essa política fez com que o abandono escolar diminuísse ao longo do tempo (CANÁRIO, 2004; CHISTÓVÃO, BRANCO, 2014). Resultado que, por si só, já é positivo, pois conseguir manter as crianças na escola, sobretudo as mais pobres, além de ser um avanço que permite 
a um contingente grande de alunos percorrer trajetórias escolares mais longas. Outro resultado alcançado foi a diminuição da "indisciplina" escolar, uma das maiores reclamações dos professores e que, de alguma forma, também contribuía para a evasão e as dificuldades de aprendizagem.

No entanto, quando se analisam os resultados de desempenho, os dados não são tão consistentes. Há agrupamentos em que se pode afirmar, a partir de avaliações internas e externas, que houve uma melhoria dos indicadores de desempenho e há outros agrupamentos em que não existem sinais claros de melhoria. Fica difícil, desse modo, afirmar com segurança que a política da TEIP é um sucesso em termos de resultados acadêmicos.

Todavia, à semelhança dos que defendem a política das ZEP francesas, os defensores das TEIP em Portugal advogam que se elas conseguirem ao menos manter níveis de sucesso próximos às demais escolas, isso, por si só, já é uma conquista importante dadas as grandes dificuldades enfrentadas pelas escolas em territórios mais pobres.

As TEIP enfrentaram ao longo do tempo muitas críticas. Uma dessas críticas mais contundentes diz respeito à construção dos diagnósticos iniciais sobre o território e sua população, primeiro passo para a elaboração da TEIP. Esses diagnósticos formaram as bases sobre as quais todo o planejamento das TEIP foi construído e também sobre as quais as ações principais foram desenvolvidas.

No entanto, como mostra Canário (op. cit.), os primeiros diagnósticos realizados por ocasião das primeiras TEIP são muito parecidos entre si, independentemente dos territórios. Ao analisá-los, percebe-se que tais relatórios afirmam e enfatizam apenas os problemas encontrados nos territórios. O pesquisador português reproduz o seguinte trecho do relatório de uma TEIP da cidade de Lisboa, que assim se referia ao território por ele atendido:

[...] uma multiplicidade de problemas de natureza socioeconômica de que se salienta: a delinquência e a marginalidade (número significativo de ex-alunos presos); desemprego e emprego sazonal; tráfico de droga; prostituição masculina e feminina elevada (CANÁRIO, 2004, p.58).

Um dos trechos do relatório da Comissão Nacional de Coordenação das TEIP referia-se à população local da seguinte maneira:

[...] Famílias numerosas; agregados familiares flutuantes; paternidades não assumidas; maus tratos; negligência; delinquência; analfabetismo; baixas 
expectativas em relação à escola; alheamento das problemáticas escolares; carências alimentares; higiene e saúde precárias; autoestima reduzida; falta de perspectivas para o futuro; deficiências de comunicação (CANÁRIO, 2004, p.59).

Percebe-se que, tanto a avaliação feita pelos agentes que fazem parte da TEIP local, quanto os da Comissão Nacional que coordena o programa, convergem ao criar um quadro absolutamente negativo a respeito dos territórios e de sua população. Percebe-se, ainda, que muitas afirmações estão baseadas mais em preconceitos e estereótipos do que em dados concretos.

Tais análises parecem enfatizar apenas os problemas, enxergando-os como uma "lista" de fatores isolados e sem relação entre si. Não se cultiva uma visão de conjunto ou de interdependência entre as questões mais importantes que se fazem presentes nos territórios pobres. Isso faz com que nos planejamentos se estruturem uma série de ações, que mais tarde se provam ineficazes e improdutivas porque são superficiais, já que alicerçadas em uma visão negativa e estereotipada dos territórios. Assim, paradoxalmente, ações pensadas para enfrentar problemas e dificuldades territoriais agravam esses mesmos problemas, apartando ainda mais as escolas de seu público. Tal situação pode mesmo criar uma ruptura entre a instituição escolar e as famílias e outros agentes locais, difícil de ser superada.

Outra crítica a ser levada em consideração é a de que as TEIP acabam, talvez por conta do próprio tipo de diagnóstico do território, produzindo o que Canário chamou de "territórios escolares", e não de territórios educativos. Isso quer dizer que, ao contrário do que foi proposto originalmente, ou seja, da constituição de ações educativas que extrapolem os muros escolares e incluam novos parceiros, como associações de pais, sindicatos, associações esportivas locais, empresas, órgãos de governo, prefeitura e pessoas, o que se tem é um domínio quase exclusivo da escola e da forma escolar sobre os projetos.

Desse modo, como apresentado no relatório do CIES e do ISCTE-IUL, as parcerias ficaram bem aquém do desejado. Na própria constituição das equipes encarregadas de planejar as ações locais e de avaliá-las, não havia a presença de outras instituições que não fossem as escolas e a administração central da direção geral de educação de Portugal (CANÁRIO, op. cit.). Assim, uma relação que deveria ser marcada pela abertura e cumplicidade, acabou por ser reduzida a ações pontuais, sendo os parceiros utilizados meramente como instrumentos da escola. 
As TEIP também sofrem com a fragmentação das ações e com o estabelecimento de muitas metas e objetivos, que se mostram difíceis de serem atingidas. Por outro lado, a esperada sinergia entre as escolas nem sempre foi possível, pois muitas acabaram não conseguindo romper com as formas tradicionais de trabalho, muitas vezes fechadas em si mesmas e pouco permeáveis.Isso tem a ver com outro ponto importante: a política das TEIP não conseguiu provocar mudanças internas nas escolas. De acordo com Canário (2004), a "forma escolar" permaneceu inalterada e constituiu um dos maiores obstáculos ao funcionamento adequado das TEIP.

O autor qualifica essa forma escolar a partir de algumas características: a ideia de uma ruptura com a experiência como forma de aprender; o desprezo pelo erro, visto como um desvio e não como oportunidade de aprendizado; a ideia de que o aprendizado se faz a partir do acúmulo e repetição de informação; a separação entre teoria e prática, sendo esta última uma mera aplicação da primeira e; finalmente, a persistência de uma leitura negativa do aluno como ser "aprendente", visto apenas como alguém que carrega uma série de lacunas que precisam ser preenchidas pelo ensino escolar.

Ao permanecerem fechadas sobre si mesmas e, ao mesmo tempo, ao trabalhar de maneira burocrática e tradicional, muitas das escolas TEIP não avançaram ou ficaram aquém do que era esperado. Obviamente, como dito acima, não se pode apenas culpar as escolas, já que estas estão inseridas em um contexto maior e dependente do nível central.

Contudo, a incapacidade de abertura da escola a outras dimensões sociais parece se refletir, em muitos momentos, no discurso saudosista de alguns professores, que evoca uma escola cujo público era menor, mais homogêneo e os problemas "de fora" ainda não haviam adentrado pelos seus portões.

O fato é que a escola, ainda hoje, passados alguns casos, mais de meio século de sua abertura às crianças de origem popular, continua com muitas dificuldades do ponto de vista sociopedagógico em atender às novas demandas trazidas por elas (SIBILIA, 2012).

É importante reconhecer, no entanto, mesmo que pareça contraditório, que a construção das ZEP e das TEIP é uma tentativa de criar práticas alternativas à forma escolar. Por outro lado, suas políticas de discriminação positiva são 
investimentos para enfrentar o grave quadro de desigualdade social enfrentado pelas populações pobres.

Essas PEP reconhecem, igualmente, que os territórios precisam ser incluídos como fatores determinantes de influência e impacto sobre o trabalho escolar. Abandona-se aqui a ideia, ainda arraigada na cultura escolar, de que a instituição escola é uma ilha que deve ser preservada da "contaminação" do lugar. Reconhece-se também que, em territórios complexos e com questões que escapam completamente ao domínio das escolas, é preciso encontrar parceiros para que a missão da escola possa ser realizada e, por fim, reconhecer-se que a escola precisa ter outro papel, para além do ensino nesses territórios.

A escola, e aí pensamos agora em termos não apenas das periferias de Paris ou de Lisboa, mas também das favelas cariocas, pode ter papel central no desenvolvimento social e cultural desses territórios. Essa não é uma tarefa fácil. Como apontado acima, as PEP, tanto na França como em Portugal, enfrentam inúmeras dificuldades para se firmarem, desde vicissitudes políticas como as trocas de governos, passando pela persistência de uma determinada forma escolar que resiste às mudanças, até as especificidades sociais dos próprios territórios.

O fato, porém, é que as PEP continuam a ser testadas como alternativas para se enfrentar questões sociais que ultrapassam os limites das escolas. Elas também se constituem em uma busca por mais qualidade na educação oferecida aos mais pobres, que é o caso, por exemplo, das "cidades educadoras", experiência nascida nos anos de 1990, na cidade de Barcelona, e que hoje constitui importante movimento mundial, com repercussões no Brasil, onde foram implementadas experiências concretas em algumas de nossas cidades. Na próxima subseção, apresentaremos mais detalhadamente essa experiência, que também está associada com o PEA/BE.

\subsection{3}

\section{Da Carta de Barcelona às Cidades Educadoras}

Em 1990, foi divulgada a Carta das Cidades Educadoras. Este documento foi resultado do congresso internacional: "Educação para a construção de uma cultura da paz", que reuniu representantes de uma série de cidades de diversas partes do mundo em Barcelona, Espanha. Um dos objetivos desse encontro foi 
criar um movimento que reconhecesse o papel das cidades como espaços de educação e formação integral de seus cidadãos.

Assim, a Carta das Cidades Educadoras firmou uma espécie de compromisso entre as cidades participantes que, ao mesmo tempo, lançou as bases para um ousado movimento que procuraria integrar cidades muito diferentes entes si, mas cujo objetivo principal era a transformação de seus espaços, equipamentos e recursos para apoiar a escola e a educação de uma maneira inovadora. A própria cidade, suas ruas, instituições públicas e privadas e seus habitantes se tornariam espaços e agentes de educação.

Por isso, a Carta caracteriza as cidades educadoras da seguinte maneira:

Hoje mais do que nunca a cidade, grande ou pequena, dispõe de inúmeras possibilidades educadoras. De uma forma ou de outra contém em si mesmo elementos importantes para uma formação integral. A cidade educadora é uma cidade com uma personalidade própria, integrada no país onde se situa. A sua identidade, portanto, é deste modo interdependente da do território de que faz parte. É também uma cidade que não está fechada sobre si mesma, mas que mantém relações com o que a rodeia - outros núcleos urbanos do seu território e cidades com características semelhantes de outros países -, com o objetivo de aprender, trocar experiências e, portanto, enriquecer a vida dos seus habitantes. A cidade educadora é um sistema complexo em constante evolução e pode exprimirse de diferentes formas, mas dará sempre prioridade absoluta ao investimento cultural e à formação permanente da sua população. (CARTA CIDADES EDUCADORAS, BARCELONA, 1990).

É interessante observar que, assim como as ZEP e a TEIP, o movimento das Cidades Educadoras também faz forte referência aos territórios, mas com uma diferença fundamental: o território em questão é a própria cidade e não apenas seus territórios mais pobres,ou seja, as Cidades Educadoras propõem uma política mais "universalista", enquanto as PEP focalizam suas ações em determinados territórios ou grupos específicos.

Em 1994, como consequência do congresso inaugural, criou-se a Associação Internacional das Cidades Educadoras (AICE), que, desde então, promove encontros cujo objetivo é o de aprimorar os compromissos assumidos na Carta de 1990 e avançar nas ações que consolidem os princípios da educação integral ${ }^{9}$.

De acordo com a AICE, o conceito de cidades educadoras significa que as cidades do século XXI, para além de suas funções econômicas, políticas e

\footnotetext{
${ }^{9}$ O Conceito de educação integral aqui proposto pode ser entendido como o desenvolvimento pleno das potencialidades socioculturais, emocionais e racionais das pessoas.
} 
culturais tradicionais, devem transformar o espaço urbano em uma "escola sem muros". A ideia é que todos trabalhem de forma integrada para a formação educacional e cultural das pessoas que vivem na cidade.

Segundo a Carta de 1990, dentre as condições básicas, para que uma cidade seja considerada como uma cidade educadora, ganham destaque: a busca pela convivência mais harmoniosa entre as gerações; a luta contra a exclusão de qualquer espécie; o protagonismo das prefeituras na condução de políticas públicas que incentivem a convivência; o reconhecimento da identidade e da memória local; a ligação entre escolarização e necessidades do mundo do trabalho e o envolvimento das comunidades externas à escola no projeto de educação integral.(CARTA DE BARCELONA, 1990).Outro aspecto que merece destaque é que a Carta das Cidades Educadoras preconiza uma verdadeira rede horizontal de cidades unidas pelas trocas de experiências e possibilidades.

As cidades educadoras irão desenvolver uma colaboração bilateral ou multilateral para a troca das suas experiências; num espírito de cooperação apoiar-se-ão mutuamente no que respeita a projetos de estudo e de investimento, quer diretamente, quer como intermediários em organismos internacionais (ibid.).

Essa é uma diferença importante com relação às ZEP e a TEIP, pois existe um movimento mais horizontal, que parte das cidades e de seus governos locais e não de governos centrais.

Por outro lado, o movimento acontece a partir de uma diversidade de cidades de partes muito diferentes do mundo, o que amplia sobremaneira o leque de experiências, pois cidades tão diferentes como Nova Iguaçu, no Rio de Janeiro, Barcelona, na Espanha, ou como Rosário, na Argentina, enfrentam realidades complexas e distintas. Talvez o que una essas experiências seja justamente aquilo que é a característica maior do movimento das cidades educadoras: a preocupação com um projeto de educação que extrapole os muros da escola e contagie a cidade.

O papel da escola passa a ser de articuladora de uma rede de agentes coletivos e individuais que se inserem no território da cidade e que assumem funções também educadoras. As cidades assumem, junto com as escolas, a necessidade de um maior envolvimento de todos os seus elementos econômicos, políticos e sociais, em um projeto mais sólido e participativo de educação integral.

No Brasil, há uma rede de Cidades Educadoras composta por quatorze cidades, entre as quais estão Porto Alegre, São Paulo, Belo Horizonte, Caxias do 
Sul e Nova Iguaçu. Representantes dessas cidades estiveram reunidos em Santo André - SP, no mês de novembro de 2015, para debater o tema: "Sustentabilidade, inclusão social e diversidade em territórios educativos".

Assim, já existem algumas iniciativas concretas sendo desenvolvidas no Brasil a partir das propostas feitas pela Carta de Barcelona como, por exemplo, o Bairro-Escola iniciado pela ONG Cidade Escola Aprendiz em São Paulo e, depois, espalhada por outras cidades. Dessa experiência inicial, nasceu o Bairro Educador na cidade do Rio de Janeiro. No próximo item, abordamos mais detalhadamente tais iniciativas.

\subsection{4}

\section{Do Bairro-Escola ao Bairro Educador}

No Brasil, a primeira experiência a acolher o conceito de Cidade Educadora foi desenvolvida por uma instituição da sociedade civil chamada Cidade Escola Aprendiz. O projeto foi iniciado em São Paulo, mais especificamente em um bairro pobre da capital paulista chamado Vila Madalena, ainda no final dos anos de 1990, onde nasceu o "Bairro-Escola".Seus idealizadores apresentam como marco fundador a experiência que tiveram ao realizar uma intervenção de arte no bairro paulista. Segundo sua descrição, foram realizadas intervenções artísticas em ruas, muros e em praça próxima à sede da instituição, cujo aspecto era o de abandono e depredação. Porém, para a surpresa de todos, as intervenções artísticas também foram depredadas e pichadas pela população.

Segundo o relato dos responsáveis pelo projeto, esse fato deixou claro que não adiantaria intervir no espaço sem a participação dos habitantes locais. Era preciso envolver as pessoas e os grupos que moravam e utilizavam o território na solução dos problemas.

De acordo com uma das gestoras da Instituição Cidade Escola Aprendiz ${ }^{10}$, a partir dessa primeira experiência, os gestores do Escola Cidade Aprendiz passaram a buscar formas de envolver a população local, sobretudo, os mais jovens, incorporando-os às intervenções artísticas de ruas, praças, muros e a outros espaços públicos no bairro

\footnotetext{
${ }^{10}$ Entrevista concedida na sede da instituição em São Paulo
} 
Como forma de continuar a sensibilizar e mobilizar os moradores da região, foi desenvolvida uma série de dispositivos pedagógicos, entre os quais destacamos a metodologia das "trilhas educativas" (CIDADE ESCOLA APRENDIZ, 2013). Trata-se da criação de "caminhos" a partir do reconhecimento do que o bairro pode oferecer em termos de oportunidades para que o ensino e aprendizagem aconteçam fora dos muros das escolas e, ao mesmo tempo, potencializem o projeto político pedagógico das unidades escolares.

É a partir dessa metodologia que nasce a ideia e o conceito de BairroEscola. Desse modo, ateliês, espaços culturais, praças, empresas e pequenos estabelecimentos comerciais viram locais de complementação da aprendizagem das crianças, e espaços antes vistos como exteriores à prática educativa ganham novas dimensões e são convocados a desempenhar novas funções.

Inspirado nas Cidades Educadoras, no Bairro-Escola, a ideia é que as pessoas e suas instituições contribuam e potencializem o ensino-aprendizagem. $\mathrm{O}$ objetivo é reconhecer que todos podem se colocar a serviço da ampliação da educação escolar, formando uma rede que interaja o tempo todo em função da formação integral das pessoas.

Quando contextualiza como seria a aplicação prática do conceito do BairroEscola e da educação integral, o Escola Cidade Aprendiz recupera a ideia das cidades educadoras.

Isto quer dizer que a escola que descrevemos deixa de ser sonho quando toda a comunidade se transforma numa grande sala de aula. Quando os alunos passam a aprender física na oficina mecânica, literatura na biblioteca do bairro, química na cozinha de um restaurante, história nos museus e monumentos, artes nos teatros e cinemas da cidade. (CIDADE ESCOLA APRENDIZ, 2013, p. 13).

De acordo com os formuladores do Projeto Bairro-Escola, ele é um meio para se chegar à Cidade Educadora, ou seja, primeiro o bairro e depois outros bairros até se atingir a escala da cidade. Nesse sentido, a experiência da Vila Madalena foi replicada e adaptada para novos contextos em outras cidades brasileiras. Em São Paulo, foram estabelecidas parcerias com a Universidade de São Paulo (USP), que capacitou 1.200 professores da rede municipal de ensino, e com a Universidade Estadual de Campinas (UNICAMP) que capacitou 5.000 diretores de escolas estaduais dentro de uma metodologia e de uma concepção de aproximação das escolas com seu bairro e com uma rede de parceiros locais. 
Os documentos do Cidade Escola Aprendiz, que apresentam o quadro de referência do que deveria ser um Bairro-Escola, enfatizam dois pressupostos básicos: o primeiro é o de que o "ato de aprender é o ato de intervir no seu meio" (CIDADE ESCOLA APRENDIZ, 2013, p. 8); e o segundo, relacionado ao primeiro, que a educação deve acontecer por meio de parcerias que fortaleçam e ampliem a educação escolar.

É preciso sublinhar que, dentre as parcerias com o entorno da escola, o Bairro-Escola procura privilegiar a comunidade/bairro e as famílias que nele habitam. Esse é um aspecto importante, pois tanto o Conceito de Cidade Educadora quanto o conceito de Bairro-Escola evidenciam que, sem a participação das comunidades e das famílias, a criação de ações que fortaleçam a educação fora da escola não se sustenta.

\subsection{5 \\ O Bairro-Escola de Nova Iguaçu}

Como dito no item anterior, algumas cidades brasileiras adotaram o modelo do Bairro-Escola, com pequenas variações de nome e funcionamento. A experiência, por exemplo, foi adaptada para Nova Iguaçu, no Rio de Janeiro, para Belo Horizonte, em Minas Gerais, para Boa Vista, em Roraima, para Praia Grande, São Bernardo, São Caetano e Taboão da Serra, em São Paulo.

No caso de Nova Iguaçu, entrevistamos para este trabalho uma das pessoas que participou da implementação e do gerenciamento do Bairro-Escola na cidade. Ela foi a gerente do Bairro-Escola e, no depoimento que colhemos, fica claro que este é um projeto inspirado na Carta de Barcelona e nos princípios das Cidades Educadoras, tal qual o projeto desenvolvido pelo Escola Cidade Aprendiz em São Paulo.

A cidade de Nova Iguaçu estendeu a todas às suas escolas públicas e a seus sessenta e oito bairros o Programa Bairro-Escola entre os anos de 2006 e 2010. O objetivo era ter um projeto da área de educação que fosse o centro de uma ação social mais ampla e que pudesse agregar outras áreas da Prefeitura para que todos agissem, em prol da melhoria da qualidade da educação, no combate à evasão escolar e na melhoria das condições de vida nos bairros.

A ideia, assim, era agir nos territórios a partir da escola para que ela fosse a catalisadora de ações interdisciplinares e intersetoriais cujo objetivo era integrar 
ações e escapar da fragmentação habitual nesse tipo de projetos.De acordo com a gestora do programa em Nova Iguaçu, uma das ações concretas realizadas no sentido de garantir coesão ao Bairro-Escola, foi a contratação de animadores culturais, universitários e estudantes do ensino médio, que ficaram encarregados de oferecer atividades culturais e esportivas no contraturno escolar.

Esses animadores culturais estavam ligados às Secretarias de Cultura, e de Esporte e Lazer, sendo por elas remunerados. Cada secretaria da Prefeitura, não apenas as duas citadas acima, tinha um coordenador que se dedicava exclusivamente ao programa, com o que se procurava garantir sua coesão e a intersetorialidade.

Outro dos pontos fortes do Bairro-Escola, segundo a gestora do programa em Nova Iguaçu, foi a criação dos editais públicos para que fossem formadas as parcerias que deveriam ajudar as escolas a criar uma rede educativa nos territórios. Dentre esses editais, um dos mais importantes foi o que criou a categoria de "mães educadoras". A partir daí algumas mulheres seriam contratadas para auxiliar as escolas no cuidado com as crianças e na interlocução com outros pais, mães e responsáveis pelos alunos.

Assim, as mães educadoras cuidavam das crianças no recreio, na entrada e na saída da escola, olhavam as crianças brincando nos pátios, no refeitório e conversavam com outras mães na porta das escolas. Elas faziam uma espécie de mediação entre a escola e a comunidade.

Para fazer esse trabalho, as mães educadoras recebiam uma remuneração mensal. Já para participar da seleção - feita pelas próprias escolas - deveriam, em primeiro lugar, pertencer ao programa de transferência de renda federal BolsaFamília, ter os filhos matriculados na escola para a qual se candidatavam e morar próximo da mesma escola. Ao que parece, a intenção era a de fortalecer as famílias que viviam em condições socioeconômicas mais difíceis e, ao mesmo tempo, reforçar os vínculos da escola com o território e com a vizinhança.

Ao todo, mil mulheres trabalharam como "mães educadoras" em Nova

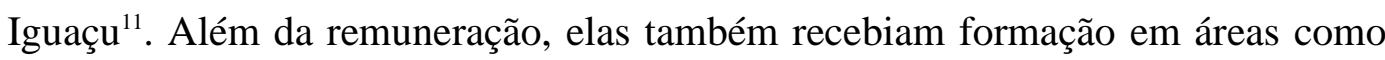
saúde da mulher, direitos e mediação de conflitos. Há aqui uma iniciativa

\footnotetext{
${ }^{11}$ Curiosamente havia apenas um homem atuando nessa função, pois o edital era aberto a todos. Mais uma vez a importância das mulheres na educação escolar se sobressai, principalmente nos territórios mais pobres.
} 
importante no que diz respeito à inclusão de mulheres cuja experiência é fundamental no território e que constituem uma fonte de conhecimento excepcional para a escola.

Tal qual as PEP, no Bairro-Escola, através da educação, procurava-se chegar às questões sociais mais sensíveis e que afligiam o cotidiano das famílias mais pobres. Questões essas muitas vezes potencializadas pelo alto grau de vulnerabilidade dos territórios.

Segundo a gestora do Bairro-Escola de Nova Iguaçu, havia uma atenção especial com as mulheres, principalmente no que diz respeito às suas condições de vida e de a renda, ao acompanhamento da escolaridade dos filhos, a relação com a comunidade/favela e os seus direitos básicos. Esse é um aspecto fundamental, pois as pesquisas mostram que são geralmente as mulheres das famílias mais pobres que cuidam da educação escolar das crianças (BATISTA; SILVA, 2013).Assim, fortalecer o papel das mulheres, reconhecendo sua importância para a escola através, inclusive,de remuneração, pode ser um bom caminho para estreitar os vínculos das crianças com a escola e com a escolarização de maneira geral.

A participação das escolas nesse tipo de programa poderia contribuir para a diminuição de estereótipos e preconceitos em razão da maior aproximação com as comunidades e com a vizinhança que as mães educadoras e as parcerias locais podem propiciar. Além disso, poderia também ser a oportunidade de uma revisão das escolas sobre a forma como atuam no território e como se relacionam com as famílias que moram nele.

O Bairro-Escola de Nova Iguaçu, em particular, possui uma diferença fundamental em relação à ZEP e à TEIP, pois, embora dê atenção especial a áreas mais pobres da cidade, não enfatiza, como ocorre na ZEP e TEIP, um território específico e um grupo de estudantes como alvo de suas ações, o que, portanto, o aproxima mais do conceito de cidades educadoras e de sua ação mais universalista.

\subsection{6}

\section{O Projeto Mais Educação}

Nos anos de 1990, a grande questão na pauta da educação no Brasil foi o alargamento da escolaridade e sua extensão para todas as crianças brasileiras 
quando a Constituição de 1988 e o Estatuto da Criança e do Adolescente asseguraram a educação escolar como um direito das crianças.

Com a entrada das crianças mais pobres, distantes do universo formal da escola, há uma inquietação por parte dos profissionais da educação diante de questões de cunho social trazidas pelo público novo.

O fato é que, com a chegada das crianças mais pobres na escola, a instituição entra em crise, pois não consegue lidar ou não entende que precisaria se adaptar à nova clientela. Assim, o discurso da crise da escola ganha corpo e se faz acompanhar, quase sempre, de uma nostalgia que fala de uma escola boa no passado, onde os alunos tinham mais qualidade, eram mais disciplinados e gostavam mais da escola e dos professores.

Nesse contexto, algumas medidas envolvendo programas, currículos e ações foram tomadas nos diferentes países para que a escola se adequasse e atendesse o novo público escolar. Como vimos, foi o caso das PEP. No caso do Brasil, em que pese a criação de programas de apoio à escola e à escolarização, a iniciativa que envolveu uma ação mais direta sobre as atividades escolares por parte do governo federal foi o Programa Mais Educação, criado em 2007.

O programa, gerenciado pelo Ministério da Educação (MEC), foi instituído pela portaria Interministerial 17/2007 e pelo Decreto Presidencial 7083/2010, passando a integrar as ações do Plano de Desenvolvimento da Educação - PDE.

As ações do Programa Mais Educação se aproximaram dos pressupostos da “educação compensatória" similares às ZEP e TEIP. Isso porque investia recursos adicionais nas escolas com baixo Índice de Desenvolvimento da Educação Básica (IDEB) e que tinham estudantes com dificuldades de aprendizagem e maior risco de evasão escolar.

De acordo com as informações do sítio eletrônico do MEC, as atividades do programa começaram no início de 2008 com "1.380 escolas, em 55 municípios nos 26 estados e no Distrito Federal, atendendo 386 mil estudantes" (MEC, 2017).

No ano seguinte, o número de escolas subiu para cinco mil em 126 municípios, que atenderam a 5,1 milhão de estudantes; em 2010, o quadro era o seguinte: atendimento a 389 municípios e cerca de 10 mil escolas, beneficiando 2,3 milhões de alunos; o último dado disponível no sítio dá conta de que o programa atendeu, em 2013, mais de 49,3 mil escolas públicas do país, com um orçamento na casa de 1,5 bilhão/ano. 
Como se pode observar, ano a ano, houve um expressivo crescimento do Mais Educação, juntamente com o montante crescente de recursos financeiros. Como consequência, houve a progressiva extensão das atividades extracurriculares no contraturno e, ainda, o crescimento contínuo do turno único, que é uma ação ligada ao conceito de educação integral defendida pelo MEC $^{12}$ (CAVALIERE, 2002).

Segundo Jaqueline Mol, esta é uma das primeiras coordenadoras do programa:

Com o desenvolvimento do PME, o número de escolas com $100 \%$ das matrículas em tempo integral aumentou 178,9\% — de 161 unidades em 2010 para 449 em 2011. O total de estudantes atendidos nessas escolas passou de 59.274 para 132.706 no mesmo período, o que significa aumento de 123,9\% (MEC, 2013).

Essa era a grande aposta do Mais Educação, ou seja, as crianças deveriam passar mais tempo na escola e ter contato com um currículo diversificado, que favorecesse, principalmente, o encontro com as artes, cultura, saúde, tecnologia, esporte e lazer.

As atividades eram realizadas, preferencialmente, por agentes locais contratados com recursos do programa, já que um ponto importante do Mais Educação era a orientação do envolvimento das escolas com o território. O objetivo era a criação de novas parcerias, nos moldes das Cidades Educadoras, que fortalecessem a ação educativa local.

Em termos de resultados acadêmicos, segundo dados divulgados por uma avaliação feita pelo instituto Itaú Social,com apoio do Banco Mundial, (FUNDAÇÃO ITAÚ SOCIAL, 2011) as escolas que aderiram ao Programa Mais Educação não conseguiram impactar significativamente os resultados de seus estudantes nos testes de língua portuguesa, matemática e os indicadores de evasão escolar.

Ao comparar escolas participantes do Programa Mais Educação com escolas não participantes, com estrutura e funcionamento semelhantes, a avaliação do Instituto Itaú Social mostrou desvantagens do primeiro grupo de escolas com relação às demais.

\footnotetext{
${ }^{12}$ A discussão sobre a educação integral é um dos temas mais intensamente debatidos hoje no meio educacional. Muitos autores dizem que a simples extensão do horário e dos turnos escolares não configura, por si só, a educação integral. Esta, por sua vez, deve estar comprometida com valores e ações que privilegiem o desenvolvimento pleno das capacidades de cada um e, ao mesmo tempo, esteja comprometida com o bem comum.
} 
Ainda de acordo com o relatório de avaliação, o fato de as escolas terem que se adequar às exigências de funcionamento do Mais Educação demanda tempo e o apoio das secretarias de educação locais. Essas condições nem sempre estavam dadas, o que teria dificultado sobremaneira o funcionamento adequado do programa.

No ano de 2016, houve uma importante mudança no Mais Educação. O programa foi atualizado pelo Ministério da Educação, através da portaria MEC n ${ }^{\circ}$ 1.144/2016. Essa portaria criou o Programa Novo Mais Educação, que assim definiu seus novos objetivos:

Em 2017, o Programa será implementado por meio da realização de acompanhamento pedagógico em Língua Portuguesa e Matemática e do desenvolvimento de atividades nos campos de artes, cultura, esporte e lazer, impulsionando a melhoria do desempenho educacional mediante a complementação da carga horária em cinco ou quinze horas semanais no turno e contraturno escolar. O Programa tem por finalidade contribuir para a:

I - Alfabetização, ampliação do letramento e melhoria do desempenho em língua portuguesa e matemática das crianças e dos adolescentes, por meio de acompanhamento pedagógico específico;

II - Redução do abandono, da reprovação, da distorção idade/ano, mediante a implementação de ações pedagógicas para melhoria do rendimento e desempenho escolar;

III - Melhoria dos resultados de aprendizagem do ensino fundamental, nos anos iniciais e finais;

IV - Ampliação do período de permanência dos alunos na escola (MEC, 2016).

Assim, no documento de criação do Novo Mais Educação, fica clara a orientação pelo reforço nas disciplinas de língua portuguesa e matemática como instrumento de melhoria do desempenho escolar dos estudantes. Quando observamos, no documento de atualização do programa, a lista de atividades sugeridas, tanto no campo da arte e cultura, quanto no campo do esporte e lazer, a ênfase recai sobre ações de cunho mais escolar. Desse modo,na nova lista não constam mais ações nas áreas de direitos humanos em educação, cultura digital, promoção da saúde, comunicação e uso de mídias.

As recomendações enfatizam o caráter formal das atividades pedagógicas e de reforço escolar, subordinando-as ao objetivo de melhorar o desempenho dos alunos, abandonando a perspectiva integradora com as comunidades e territórios e centralizando suas ações no interior da escola. Essa é uma mudança de direção importante que foge ao conceito das Cidades Educadoras que, até então, orientava as ações do programa. 
A situação se agravou com a diminuição do número de escolas atendidas pelo Novo Mais Educação. O número caiu, em 2016, para 28 mil escolas. Com a grave crise política pelo qual o Brasil atravessa desde o impeachment da presidenta da República Dilma Rousseff, a situação do Programa Novo Mais Educação se tornou incerta. O novo governo, ao que tudo indica, não vê como prioridade o programa, pois, até agora, ainda não o atualizou.

A mudança de foco e a paralisação do Programa Mais Educação podem ser vistos como um retrocesso em termos de incentivo à escolarização das crianças mais pobres e à aproximação com as famílias e seus territórios.

Esta não é uma especificidade do Brasil. As PEP também se mostram suscetíveis às mudanças políticas, econômicas e culturais da contemporaneidade. Ao longo do tempo elas também sofreram mudanças, umas mais radicais outras mais moderadas, é o que veremos a seguir.

\section{2}

\section{As três idades das PEP}

O pesquisador francês Jean-Yves Rochex (2011), ao fazer uma análise sobre oito Programas de Educação Prioritária na Europa, apresenta um quadro comparativo no qual é possível distinguir mudanças de direção e foco nessas políticas ao longo do tempo. O pesquisador conseguiu distinguir três grandes momentos ou, como ele chama: três "idades" das PEP.

A primeira idade tem início ainda nos anos de 1970-1980 e suas experiências são marcadas pela ideia de déficits culturais, linguísticos, educacionais e sociais, que deveriam ser corrigidos ou compensados pela escola e pelos Programas de Educação Prioritária. Tais ações deveriam ser dirigidasaos alunos mais pobres, "deficitários", e distantes do universo escolar para que eles pudessem, de fato, se beneficiar do processo de escolarização (ROCHEX, 2011, p. 873).

Nesse primeiro momento, o Estado desempenhou o papel de "educador e organizador das normas e regras" que, a priori, deveriam garantir o acesso à escola e a oportunidades de aprendizagem para todos. Ou seja, tomou para si a tarefa de organizar as ações que deveriam corrigir os problemas detectados nos territórios mais pobres. 
Assim, as ações das primeiras PEP serão ajustadas no sentido de dar "mais a quem tem menos". As escolas cujos alunos são considerados "deficitários" receberam atenção especial traduzida em ações suplementares (reforço escolar, projetos de acompanhamento acadêmico individualizado, entre outras), investimentos financeiros maiores e ampliação e diversificação do currículo escolar.

$O$ pesquisador francês insere as primeiras PEP no quadro de desenvolvimento do Estado de Bem-Estar Social na Europa do pós-guerra. Nesse momento, havia a preocupação com a formação das novas gerações e a aposta principal no campo da educação era a de que a escola deveria deixar de ser uma instituição fechada e elitista para se transformar em uma instituição mais aberta, unificada onde a meritocracia fosse a única condição para o progresso (ibid., p. 872).

Por isso, a escola deveria ter duas tarefas principais: ajudar a corrigir os déficits culturais dos alunos mais distantes do seu universo e, como consequência dessa primeira tarefa, ajudar a diminuir as desigualdades sociais ao oferecer condições às crianças mais pobres para que elas progredissem socialmente através da educação escolar.

No entanto, ao não poder acabar com as desigualdades sociais ligadas à própria dinâmica da sociedade capitalista - por essência desigual - ou, ao acreditar que os "déficits" poderiam ser corrigidos apenas oferecendo mais recursos escolares e tratamento especifico para as escolas e grupos de alunos, a chamada "discriminação positiva", as primeiras PEP acabaram frustrando muitas expectativas.

Isso expôs ainda mais as divisões internas inerentes aos grupos que reivindicavam mudanças nas PEP. É importante frisar que uma das características mais proeminentes das primeiras PEP, segundo Rochex, era a constante tensão entre uma visão "corretora de déficits" e uma visão que enxergava a escola como uma ferramenta de transformação da própria sociedade.

Assim, o atrito entre essas duas correntes

[...] se faz ouvir igualmente na tensão ou contradição entre uma visada corretora, cujo objetivo é reduzir as desigualdades sociais nos sistemas educativos, sem questionar seus modos de funcionamento, e uma abordagem transformadora, que adota medidas visando melhorar o sucesso escolar e aumentar os poderes sociais das categorias da população alvo, um meio de operar não apenas a melhora, mas a transformação da instituição escolar, elaborando e pondo em prática os modos de 
fazer não somente mais eficazes, porém menos socialmente privilegiadores e menos arbitrários - em outras palavras emancipadores (ROCHEX, 2011).

Não sem propósito, a primeira idade das PEP se encerra sob a frustação de promessas não cumpridas e sob as críticas de correntes políticas tanto da direita como da esquerda. A primeira corrente criticava as PEP por acreditar que elas não foram eficazes por não atenderem as demandas dos mercados de mão-de-obra com mais qualidade e competitiva. Já a segunda corrente, se via frustrada porque as Políticas de Educação Prioritária não conseguiram cumprir, sob sua ótica, as promessas de maior igualdade e de transformação democrática do campo educacional e do campo social.

Segue-se a essas críticas uma reformulação das PEP. As mudanças que se processam estão ligadas, inevitavelmente, às transformações sociais mais gerais pelas quais passou a sociedade mundial e a europeia em particular. Assim, a marca da segunda idade das PEP é uma virada que se aproxima de valores do “novo liberalismo", ou neoliberalismo, dos anos de 1990.

Desse modo, o Estado passou de "educador e orientador" para um Estado "regulador do quase mercado", condizente com as orientações dos novos governos que defendiam a ideia do "estado mínimo". A partir dessa reorientação do papel do Estado, as PEP passam a definir que o objetivo de suas iniciativas seria lutar contra a exclusão educacional e social. Assim, os esforços para acabar com as desigualdades escolares e sociais, marcas da primeira idade das PEP, são substituídos pela luta a favor da "equidade" e da inclusão (ibid., p.874).

Os formuladores das novas PEP se apropriam da retórica da "equidade" e das "competências-chave" (ibid.), afirmando, diante das críticas, não haver o abandono da defesa da igualdade, mas sim uma ampliação da mesma, uma vez que a equidade englobaria várias formas de igualdade (igualdade de acesso, igualdade nas condições para aprender, igualdade de resultados).

Desse modo, afirmam os formuladores dos novos Programas de Educação Prioritária, a igualdade deixaria de ser apenas uma formalidade, que nem sempre correspondia à verdade, para se transformar em realidade de fato, a partir da equalização das oportunidades educacionais e sociais.

Contudo, segundo os críticos dessa ideia, com o abandono da defesa da igualdade, o que acabou por se sobrepor foi a ideia de um "mínimo comum", que todos os alunos deveriam adquirir para que fossem "incluídos" no sistema escolar. 
A equidade, ainda segundo seus críticos, embora reconhecida como importante, acabava, assim, por construir uma espécie de acomodação às desigualdades sociais, visto que elas passaram a ser naturalizadas e aceitas como tal.

O principal objetivo da nova geração das PEP deveria ser o de garantir o bom funcionamento de uma sociedade na qual todos deveriam ter iguais oportunidades para competir.

Outra marca fundamental dessa segunda idade das PEP é que o enfoque deixa de recair sobre os "estudantes deficitários" para enfatizar as "zonas" ou os "públicos difíceis" (op. cit., p. 875). Essa é uma virada importante, pois o território aparece agora como um dado fundamental para a aplicação de medidas e investimentos públicos em termos de educação e programas sociais.

Se na primeira "idade das PEP” havia uma preocupação muito maior com o investimento nas escolas que abrigavam os alunos "deficitários", embora o território fosse considerado, o que se tem agora é uma maior preocupação com o território em que as escolas estão localizadas.

No entanto, o que Rochex demonstra, a partir da comparação que faz entre as diferentes PEP, é que a referência ao território será quase sempre negativa. Isso fica nítido ao se analisar os diagnósticos sociais que serviram de base para os planejamentos de construção das PEP. Sempre que houve menção ao território e à população que nele habita, esta foi depreciativa e enfocou apenas os problemas e as dificuldades. É como se esses territórios não abrigassem qualidades que pudessem ser utilizadas pelas escolas, pelo Estado e pela sociedade para ajudar a promover maior qualidade na educação.

Desse modo, de espaço cujos recursos poderiam servir para a construção de uma nova ordem social, mais igualitária e emancipadora - como era a crença nas primeiras PEP - o território passou a ser caracterizado como um "problema e uma ameaça à ordem" (ibid., p. 876).

Era preciso, segundo os formuladores das novas PEP, que o Estado realizasse, através de políticas focalizadas e direcionadas aos "territórios problemáticos", as ações necessárias para que escolas e seus parceiros locais pudessem promover o "reparo" nos problemas socioeducacionais mais urgentes. Era preciso trabalhar pela inclusão social de grupos que acabariam "ficando de fora”, os excluídos do "empreendimento social comum", se nada fosse feito (ibid., 
p. 875). Assim, as causas da exclusão, como a desigualdade social, foram esquecidas.

O avanço sobre o tema da exclusão ou da inclusão, segundo Rochex, abre caminho para aquilo que o autor chamou de "terceira idade das PEP" (ibid., p 876). Nesse novo momento, diferentes países optaram por aprofundar os programas contra a exclusão e, para tanto, passaram a desenvolver dispositivos para identificar os grupos e indivíduos que mais corriam o rico de "serem excluídos" do sistema escolar.

A partir daí a menção ao território é obliterada, bem como a ideia de compensação que ainda persistia de alguma forma. O que se coloca no lugar é a lógica da "maximização das oportunidades de sucesso individual" através de uma “escola inclusiva” e de excelência (ibid., p. 876).

$\mathrm{Na}$ verdade, a retórica da escola inclusiva servirá apenas como "pano de fundo" para justificar a ação sobre os indivíduos e grupos de indivíduos considerados de "risco". Nessa nova orientação das PEP, não se discutem os processos escolares e sociais altamente desiguais que levaram indivíduos ou grupos de indivíduos ao risco de serem colocados precocemente para fora da escola.

Na continuação dessa lógica, os sistemas escolares deveriam ser flexíveis o bastante para se acomodarem à gama complexa e fragmentada de características dos indivíduos, suas necessidades e talentos. Para tanto, houve uma verdadeira proliferação de dispositivos educacionais e programas sociais para atender a uma série de "novos públicos", que foram criados a partir de indicadores construídos com base em pressupostos como saúde, etnia, língua, necessidades especiais e identidade.

Por outro lado, as escolas, independentemente dos territórios em que se localizassem, deveriam permitir, e mesmo incentivar, a seus alunos o desenvolvimento de suas potencialidades, dando-lhes a chance de maximizar seus talentos. Mais uma vez, afirma-se a ideia de maximização das oportunidades individuais como a ação mais importante da nova geração das PEP. O indivíduo agora está no centro das preocupações das Políticas de Educação Prioritária, não mais os territórios ou as escolas. 
Um bom exemplo dessa nova orientação é o recrutamento de uma espécie de elite formada por alunos pertencentes a escolas ZEP, realizado a partir de 2001, na França, pelo Instituto de Estudos Políticos de Paris.

Rochex (2011) refere-se às ações dessa política como maneira de ampliar o acesso

[...] às formas de cultura mais legítimas de que se beneficiariam os bons alunos dos bairros e estabelecimentos aos quais faltariam a proximidade e a conivência cultural requeridas, e, por outro lado e pela mesma razão, de 'estimular de forma mais decisiva a jovem elite escolar que emerge dos bairros populares' (ibid., p. 878).

Desse modo, o objetivo era o de democratizar o acesso aos colégios mais prestigiados, franqueando-se a entrada de uma jovem elite dos bairros mais pobres. Segundo Jean-Yves Rochex, tal processo, iniciado no ensino médio, não tardaria a se estender ao ensino fundamental. Em síntese, Rochex define os objetivos da terceira idade das PEP na França da seguinte forma:

Formuladas em termos de modernização ou inovação, elas não cedem mais lugar a uma ambição de justiça social à visada redistributiva, nem aos objetivos de transformação e democratização do sistema educativo; elas se inscrevem numa visão recém renovada da competição meritocrática em face da instituição e da cultura escolar, cujos estímulos e efeitos socialmente desigualitários não estão mais em questão. A sorte dos alunos insuficientemente talentosos merecendo aceder a excelência, dos vencidos da competição escolar ou dos alunos assim considerados nem por isso é esquecida. Mas as medidas e os objetivos a eles concernentes são centralizados muito explicitamente nos objetivos que se referem à aquisição, por todos os alunos, do alicerce mínimo de conhecimentos e competências (a grande maioria das pesquisas sobre as adaptações curriculares em ZEP permite pensar que se passará para uma versão muito leve, mínima e centrada em competências muito estreitas), e na multiplicação de dispositivos visando, dentro e, sobretudo, fora da escola, ao amparo individualizado dos alunos com maiores dificuldades, os quais já não constituem tanto uma responsabilidade do Estado e de seus escalões desconcentrados, mas das coletividades territoriais e, particularmente, das municipalidades (op. cit., p. 879).

A terceira Idade das PEP, assim, opera a partir de duas teses principais: de um lado, os programas, como as ZEP, têm a obrigação de oferecer um mínimo a ser aprendido pela maioria dos estudantes, para que eles possam permanecer na escola e dar sua contribuição à sociedade; já no extremo oposto, a obrigação se concentra naquilo que uma minoria de talentos pode receber para maximizar suas oportunidades.

Nesse processo, a reivindicação de igualdade desaparece. Esse desenho das PEP faz coro às ações no campo macrossocial das atuais políticas econômicas de 
orientação neoliberal, nas quais as escolas assumem o papel de instituições promotoras dos indivíduos.

Desse modo, as questões coletivas são subjugadas em nome de um hiperindividualismo, visto como a virtude das sociedades contemporâneas justamente por responder aos anseios do novo homo economicus do século XXI.

No presente, as PEP continuam a funcionar, apesar das muitas críticas, das mudanças pelas quais passaram e de variarem muito de país para país e entre sistemas educacionais ao longo dos anos. Talvez a insistência na manutenção dessas políticas se deva à crença de que a educação ainda tem um papel fundamental para cumprir no que concerne às questões ligadas às transformações e permanências dos processos históricos e sociais.

Por fim, é nesse quadro mais geral das PEP que se inscrevem os programas Mais Educação e PEA/BE. Acreditamos que eles carregam consigo características mais próximas do que Rochex definiu como a segunda idade das PEP, pois afirmam conceitos como territórios, equidade e inclusão.

De todo modo, para efeitos deste trabalho, observaremos mais de perto o $\mathrm{PEA} / \mathrm{BE}$, pois ele nos permitirá uma maior aproximação com o tema das relações escola-família-vizinhança, tendo a favela da Maré como referência. 


\section{O Programa Escolas do Amanhã e o Bairro Educador}

A Secretaria de Educação do Município do Rio de Janeiro (SME-RJ) implementou, em 2009, o Programa Escolas do Amanhã (PEA)em sua rede de ensino. O PEA passou a atuar em 155 escolas, 14\% da rede municipal, localizadas no que a SME-RJ chamou de "áreas conflagradas da cidade". São escolas que atendem a 105 mil estudantes, 15\% das matrículas da rede, cujos indicadores de desempenho escolar são baixos e os indicadores de evasão, reprovação e atraso são altos (CIEDS, 2013).

Dentre as atividades desenvolvidas pelo PEA estão os Núcleos de Saúde: ações de promoção e prevenção de atenção à saúde; Cientistas do Amanhã: valorização do ensino de ciências através de um convênio com a empresa Sangari (atualmente "Abramundo"), que desenvolve materiais pedagógicos para escolas do ensino fundamental ${ }^{13}$; Salas de Leitura; Laboratórios de informática: com aulas de informática e acesso à internet banda larga; Escola 3.0: computador, projetor e aparelhos de som em todas as salas de aula e, por fim, a assinatura do Termo de Compromisso de Desempenho Escolar, pelo qual os funcionários e professores, que atingissem determinadas metas de aprendizagem e gestão, seriam recompensados financeiramente.

Desse modo, o PEA tem como proposta fundamental oferecer uma série de atividades culturais, sociais e científicas, bem como atividades relacionadas à tecnologia da informação e de saúde que procuram ampliar o capital escolar e a qualidade da educação dos estudantes das escolas atendidas. Em conjunto com as ações listadas acima, merece destaque o "Bairro Educador" ${ }^{14}$,ação desenvolvida entre os anos de 2010-2013 por uma ONG ${ }^{15}$ contratada pela SME-RJ. De acordo com o projeto, após 2013, as próprias escolas passariam a gerir suas redes de apoio formadas a partir do Bairro Educador.

Neste trabalho, pretendemos observar mais de perto o Bairro Educador por ser ele a ação do PEA que, de modo mais específico, teria o objetivo de articular

\footnotetext{
${ }^{13}$ Esse projeto procura incentivar o aprendizado das crianças através do uso de materiais didáticos especialmente voltados para a área de ciências. Os alunos tinham acesso a pequenas experiências e a "Kits" científicos para desenvolverem experimentos em sala de aula.

${ }^{14}$ Instituído oficialmente pelo decreto municipal n ${ }^{0} 30.934$ em 31 de junho de 2009.

${ }^{15}$ Centro Integrado de Estudos e Programas de Desenvolvimento Sustentável (CIEDS).
} 
comunidades/favelas, escolas públicas e famílias dentro de uma proposta integrada de cooperação. O Bairro Educador afirma que a aproximação entre escolas públicas e famílias populares é uma estratégia para o aprendizado das crianças e que a transformação do bairro das unidades escolares em local potencializador do ensino escolar é um dos caminhos possíveis para o sucesso escolar das crianças de origem popular (CIEDS, 2013).

Assim, a ideia básica dessa ação é tornar o bairro um espaço de aprendizagem mais amplo, o que significa reconhecer a importância do ambiente social do entorno da escola e da sua potencial influência positiva sobre a mesma. Essas ideias se consolidam no material que compõe a proposta do Bairro Educador, formado por quatro publicações: a) Grêmio é fundamental: um guia para implementação; b) Práticas e Aprendizagens: um relato de experiências; c) Rio, cidade que educa: guia de recursos educativos; e, d) Traçado Metodológico: um caminho percorrido.

No primeiro caderno, Grêmio é fundamental: um guia para implementação, há uma série de sugestões e orientações no sentido de auxiliar os alunos das escolas atendidas pelo Bairro Educador a se organizarem e constituírem um Grêmio Escolar. Assim, o Caderno incentiva os alunos a se organizarem para atuar de forma proativa nas questões escolares e mesmo na dinâmica das aulas, a partir da constituição de um Grêmio (2013, p. 15).

No caderno"Práticas e Aprendizagens: um relato de experiências" existe um detalhamento maior das ações realizadas pelo PEA, através do Bairro Educador, em alguns espaços da cidade, especialmente em favelas, como o Morro do Alemão, Morro da Formiga e Cidade de Deus (2013). O relato de experiências nos ajudam a traçar um paralelo entre as ações do PEA na Maré e em outros espaços da cidade.

No terceiro caderno, "Rio, cidade que educa: guia de recursos educativos", há uma espécie de mapas dos espaços da cidade do Rio de Janeiro que foram atendidos pelo PEA e o Bairro Educador (2013). Nos bairros estão georreferenciados todos os parceiros das escolas que, de alguma maneira, contribuíram para o Programa. Tem-se, assim, uma ideia das potencialidades oferecidas às escolas e famílias localizadas nos espaços atendidos pelo PEA/Bairro Educador. 
Tais documentos foram úteis para a nossa pesquisa na medida em que trouxeram relatos de experiências concretas e também propostas para a aproximação entre escolas, famílias e vizinhança. Contudo, para efeitos de nossa pesquisa, nos deteremos mais especificamente sobre a última dessas publicações, ou seja, "Traçado Metodológico: um caminho percorrido" (2013), por ser ela a que apresenta os fundamentos teórico-metodológicos do Bairro Educador, bem como seus objetivos, além de tratar, mais detalhadamente, das etapas para a construção de um "bairro educador".

De acordo com esse caderno, as escolas integrantes do projeto Bairro Educador, situadas em 49 bairros da cidade do Rio de Janeiro, desenvolvem estratégias de ação de acordo com as características de cada bairro onde se localizam. O Bairro Educador, no entanto, foi uma ação que se limitou ao período de 2010-2013, conforme previsto pelos formuladores do PEA/BE. Cabe ressaltar que o Programa Escolas do Amanhã continua sendo executado como política da SME-RJ, mas sem o projeto Bairro Educador.

Segundo os formuladores do PEA/BE, uma das metas estabelecidas foi que, ao final do período 2010-2013, as próprias escolas assumissem o papel de articuladoras da rede de apoio formada com a ajuda dos agentes da ONG, que desenvolveu a aproximação das escolas com as comunidades.

Assim, as próprias escolas deveriam ser responsáveis pelas ações do Bairro Educador e pela articulação de uma rede de pessoas, instituições, espaços informais e agências públicas reunidas com o objetivo de melhorar a educação escolar, a partir das potencialidades do bairro ou comunidade onde elas se inserem. Esse foi um de nossos pontos de atenção quando entrevistamos os profissionais das escolas e os responsáveis pelos alunos.

Como já assinalado, a iniciativa do Bairro Educador se inspirou em outra experiência, iniciada no final dos anos 1990, em São Paulo. Lá, uma instituição chamada Cidade Escola Aprendiz desenvolveu uma nova tecnologia educacional que procurava transformar a escola em uma "catalisadora" de potencialidades presentes no seu bairro (CIDADE APRENDIZ, 2000).

Ao mesmo tempo, as ações caminhavam no sentido de construir parcerias entre os agentes locais e a escola para que esta pudesse expandir a educação para além de seus muros. Essa ação procurava envolver a vizinhança e o bairro onde se 
situavam as unidades escolares e também as famílias dos estudantes no processo educativo de seus filhos.

$\mathrm{Na}$ cidade do Rio de Janeiro, o Bairro Escola foi adaptado e inspirou a criação do Bairro Educador. Ele adotou os seguintes princípios básicos ${ }^{16}$ : transcendência (a educação transcende a unidade escolar); permeabilidade (os projetos pedagógicos passam a fazer parte da cultura das pessoas); conectividade (a educação é promovida por uma rede de cooperação e ação conjunta desenvolvida por diversos agentes sociais); corresponsabilidade (famílias, escolas, governos, intuições sociais e empresas têm responsabilidade na formação das crianças) e pluralidade (a educação integral, meta a ser atingida, é fruto de uma ação intersetorial desenvolvida a partir de valorização da diversidade, do respeito e do diálogo) (CIEDS b, 2013).

No documento que define os objetivos do Bairro Educador, procura-se estimular uma educação mais contextualizada e são articuladas estratégias de aproximação com as famílias e a vizinhança das escolas.

Assim:

[...] o Bairro Educador pretende:

I - Enfatizar o papel da educação na formação de indivíduos autônomos, solidários e corresponsáveis por sua transformação e de sua comunidade;

II - Fortalecer as potencialidades comunitárias existentes, resignificando e revitalizando os espaços públicos por meio da educação;

III - desenvolver um novo modelo de gestão de parcerias visando transformar a comunidade em extensão do espaço escolar, de forma que o processo ensinoaprendizagem se integre definitivamente à vida cotidiana;

IV - Estabelecer parcerias com diferentes setores da comunidade - empresariado, famílias, organizações sociais, instituições de ensino, lideranças comunitárias e demais pessoas físicas - estimulando-os a desenvolver um olhar educativo, voltado para o aprendizado permanente. (CIEDS b, 2013, p. 7).

Fica evidente que, dentre os objetivos principais do Bairro Educador, merece destaque a busca do envolvimento e do apoio da comunidade local à escola e à escolarização das crianças do bairro. Isso significaria identificar e explorar as potencialidades presentes nos espaços onde se localizam as unidades escolares em benefício destas (CIEDS a, 2013, p. 8).

No que concerne à metodologia de trabalho, o Bairro Educador é construído a partir de três ações complementares: Trilhas educativas; Articulação local e Comunicação comunitária.

\footnotetext{
${ }^{16}$ Tais princípios se inspiram na experiência do Bairro Escola desenvolvido em São Paulo pela Associação Cidade Escola Aprendiz.
} 
Segundo os gestores do PEA/BE, as Trilhas educativas são "caminhos pedagógicos" (CIEDS b, 2013, p. 17.) construídos a partir das oportunidades oferecidas pelo território onde se localizam as unidades escolares. Essas trilhas podem ser desenvolvidas a partir de espaços formais ou informais variados, tais como ateliês, estúdios, galerias de arte, praças, museus, empresas, teatros, cinemas, centros esportivos etc. O que importa é que esses espaços estejam dispostos a aderir à ideia de uma "educação integral", ou seja, uma educação que não se restrinja ao tempo e espaço da escola. Percebe-se aqui uma aproximação com a ideia das cidades educadoras e a adoção de uma retórica próxima à Carta de Barcelona.

Junto ao desenvolvimento das trilhas educativas seria necessária, ainda, a estruturação de uma "articulação local", a partir da construção de um mapa do bairro (ibid., p.20).Esse mapa deveria traduzir o contexto da vizinhança da escola, ou seja, nele deveria ser possível visualizar outras escolas, instituições sociais, governamentais e possíveis parceiros.

A recomendação prática feita pelos articuladores do Bairro Educador é que seja construído um mapa digital local e que se utilizem os recursos da Internet e programas de computador disponíveis na rede para a realização de uma pesquisa inicial sobre os territórios. A terceira ação fundamental para a constituição de um Bairro Educador é o fortalecimento da comunicação entre os agentes envolvidos. A "ação comunicativa" teria a função de ligar, articular e fazer circular as notícias (op. cit.). Não há um formato pré-definido e nem uma regra estabelecida quanto às formas ou às ações de comunicação. A intenção é que a circulação das informações chegue ao bairro para que isso facilite a aproximação entre escolas e comunidade, mas, embora existam sugestões de atividades, como saraus e gincanas, não há a definição de uma forma privilegiada de comunicação.

Por fim, os formuladores do Bairro Educador advertem para o fato de que não se conseguirá estabelecer uma rede de apoio à escola de uma única vez. Esse é um trabalho continuo e sempre renovado. Sugerem, ainda, alguns passos para que a rede de apoio, Bairro Educador, funcione adequadamente:

1 - Seus representantes devem trabalhar em busca de um Projeto Educativo para a comunidade, integrando a escola e/ou apoiando a escola no seu PPP e colaborando com as demandas da escola.

2 - Seus representantes devem receber regularmente algum material escrito como um boletim ou informativo sempre personalizado mostrando as conquistas e desafios existentes e demonstrando a importância de cada integrante do grupo. 
3 - Para os que têm acesso à Internet, um site ou blog do Bairro Educador será um ótimo instrumento, desde que seja atualizado regularmente, com informações sobre as instituições e/ou pessoas ligadas mostrando como está a relação escola e comunidade.

4 - Para a entrada de cada instituição e/ou pessoa deve ser utilizado um termo de adesão voluntária onde constarão todos os dados da instituição, principalmente indicando de que forma pode contribuir com a rede.

5 - Deve-se promover uma capacitação para os representantes a fim de melhor integrá-los.

6 - A articulação do grupo tem que ser permanente. Isso quer dizer que, a cada instante, seu mapa será diferente, pois alguns integrantes sairão (ou se afastarão) enquanto outros entrarão. $\mathrm{O}$ esforço de articular a rede não deve cessar jamais.

7 - Não adianta articular a rede como uma forma de controle e condução das pessoas, para levá-las a cumprir uma tarefa que desejamos. A rede deve ser capaz de tomar decisões autonomamente, condição para sua sustentabilidade. (CIEDS b, 2013, p. 22).

É importante frisar que, no caderno "Traçado Metodológico", existem outras recomendações e orientações para o cumprimento das ações e das etapas preliminares a serem vencidas pela equipe do Bairro Educador e das escolas para que se configure, de fato, uma rede interativa de apoio às escolas.

Assim, o PEA/BE aposta em uma aproximação das escolas com as famílias e com o lugar em que estas moram, o que talvez seja a maior virtude da ideia do Bairro Educador.

Ações desse tipo podem transformar a educação escolar nos territórios mais pobres da cidade. Por isso, nossa pesquisa privilegiou esse aspecto ao indagar aos envolvidos, tanto aqueles que implementaram tal política, quanto os beneficiados por ela, se eles confirmavam ou não que as escolas atendidas pelo PEA/BE realmente haviam se aproximado mais de seu entrono e das famílias dos alunos. 


\section{5 \\ Referências conceituais e metodologia da pesquisa}

\section{1 Definições iniciais}

A partir da revisão de literatura que fizemos, reafirmamos nossa pesquisa no campo dos estudos que examinam as relações entre escolas públicas, famílias de origem popular e vizinhanças vulneráveis ou pobres. Esses estudos procuram entender, sob diversos ângulos, como se estabelecem, desenvolvem e resolvem os conflitos gerados entre os principais agentes socializadores das crianças nas sociedades contemporâneas, ou seja, as escolas e as famílias, levando-se em conta o contexto em que essas relações acontecem: vizinhança ${ }^{17}$.O campo de estudos ao qual nos reportamos procura, assim, compreender a maneira pela qual as relações apresentadas acima afetam o trabalho escolar e como as comunidades vizinhas, sobretudo as mais pobres, se beneficiam ou não de uma maior proximidade com as instituições de ensino.

Nesse sentido, quando buscamos compor um quadro teórico que nos ajude a entender melhor por onde passam as relações escola-família-vizinhança, procuramos apoio em DanielThin, Pedro Silva e Marcelo Burgos. Esses são os autores com os quais mais dialogamos para a construção das questões pertinentes ao nosso trabalho. Assim, partimos do pressuposto de que os conceitos de "lógicas socializadoras antinômicas" (THIN, 2006), de relações "armadilhadas" (SILVA, 2003) e de "mundo do aluno" (BURGOS, 2014) nos permitem refletir sobre as condições em que se operam as relações entre instâncias diferenciadas de socialização das crianças de origem popular.

O trabalho de Carolina Flores (2008) também é uma referência no que concerne às questões relacionadas à escola, a família e ao território, pois suas categorias de análise nos permitem compreender melhor a relação entre o local de moradia e as oportunidades educacionais, bem como a influência do lugar sobre o próprio trabalho das escolas. Nas seções subsequentes observaremos cada uma dessas referências e conceitos mais detidamente.

\footnotetext{
${ }^{17}$ Mais adiante discutiremos melhor o conceito de vizinhança.
} 


\section{2 \\ As lógicas antinômicas}

O conceito de "lógicas antinômicas", nos parâmetros apresentados por Daniel Thin (2006), nos permite estabelecer que há mais do que apenas uma relação conflituosa entre escolas públicas e famílias de origem popular, uma verdadeira relação de oposição, separação e apartamento.

A escola possui, em suas estruturas, um determinado modo de estar no mundo, de se relacionar com o tempo, de regular os corpos e uma disciplina e linguagem próprias, que não são dominados pelos grupos oriundos dos meios populares (ibid.). Por outro lado, as crianças de famílias dos meios populares são socializadas em conformidade com o que suas famílias vivenciam nos seus territórios, tendo como referencial o mundo prático do trabalho, os limites da pobreza, as questões comunitárias e a sobrevivência imediata.

Tudo isso, por sua vez, determina uma postura específica frente à escola e frente ao saber escolar. Essa forma de estar no mundo das crianças de origem popular muitas vezes se choca com o que a escola espera em termos de comportamento e engajamento escolar. Daí que os embates, mal-entendidos e desencontros acontecem.

Assim, as crianças de famílias oriundas de territórios marcados pela pobreza e vulneráveis- principalmente do ponto de vista da garantia de direitos básicos entram em desvantagem no jogo escolar devido à desigualdade entre o seu capital cultural familiar e o capital cultural valorizado pela escola (BOURDIEU, 2012). Desse modo, temos duas lógicas de socialização, de escolas e famílias, que caminham em paralelo e se confrontam, de modo mais ou menos aberto, tendo a criança como centro de uma disputa não declarada e muitas vezes não percebida como tal.

Quando escolas e famílias não estão em sintonia, quando não estabelecem uma relação de complementariedade, ou, ainda, quando mantém relação apenas formal - "cada um cumprindo seu papel” - no que diz respeito à educação das crianças, são justamente as crianças das camadas populares as que mais perdem, porque ficam a meio caminho entre o que o que é valorizado pelo mundo escolar e o que valorizado pelo seu próprio mundo. Assim, entendemos que a superação dessa antinomia, da qual nos fala Thin, é um dos maiores desafios da escola contemporânea e também uma necessidade que se impõe. 
Não temos dúvidas, porém, que para superar a antinomia entre as lógicas socializadoras de escolas e famílias é preciso que a instituição escolar dê o primeiro passo. Isso porque nessa relação ela é o "lado mais forte", pois tem o poder de normatizar, criar sanções e julgar os aptos e os não aptos a permanecerem em seu interior (LAIRE, 1998).

É a escola quem distribui os títulos e sanciona as carreiras escolares "escolhendo os melhores" e relegando os piores. Por isso, ela deve ser a "parte" que inicia a desconstrução da relação antinômica com as famílias e isso começa por conhecer mais e melhor seu aluno, sua família e o território onde se realiza o trabalho. Em suma, a escola deve conhecer o mundo do aluno se quiser realmente desenvolver uma relação mais positiva e produtiva com seu público.

\section{3}

\section{O mundo do aluno}

O conceito de "mundo do aluno" com o qual trabalhamos é o que Marcelo Burgos caracteriza como "o universo subjetivo do aluno, associado ao lugar e às condições de vida, à sua família e sua relação com a escola" (BURGOS, 2014, p. 9). Esse conceito será particularmente importante para nosso trabalho porque permite-nos observar o "sujeito por trás do aluno" (ibid.), ou seja, permite-nos conhecer quem são as crianças que chegam às escolas públicas e o que elas carregam consigo quando ingressam nas salas de aula das escolas da favela da Maré.

Para nosso trabalho, conhecer a realidade das crianças - transformadas em alunos quando entram em contato com as escolas - é fundamental, pois isso ilumina um aspecto que a escola pública brasileira, em especial a localizada nas periferias e favelas, acaba por negligenciar: a realidade geográfica, social, subjetiva, experiências materiais e as redes sociais locais que constituem a vida da maior parte de seu público.

Nesse sentido, nos será muito útil observar mais de perto a análise dos processos daquilo que Burgos nomeia como a "construção social do aluno" (op. cit., p. 10). O autor reconhece o lugar central dessa construção a partir da definição "da utopia democrática do século XIX” (BURGOS, 2014).

Nesse sentido, o caso francês é exemplar, pois a construção social do aluno se confundiria, por exemplo, com a própria consolidação da República Francesa e 
seu ideal de igualdade. Tal processo se deu ancorado na ideia de anonimato e impessoalidade do alunado corporificando, assim, a ideia de um tratamento igualitário e republicano para todos. O papel da escola seria o de "neutralizar ao máximo as diferenças externas oriundas da vida fora da escola, ao mesmo tempo em que forja em cada criança uma individualidade abstrata, que diferencia e iguala" (ibid.).

Citando Durkheim, Burgos (op. cit.), explica o conceito ao afirmar que esse movimento no campo da educação está em sintonia com um processo social maior. Este define a sociedade moderna também a partir do que iguala e diferencia os indivíduos. Assim, o processo de socialização das novas gerações, ao inseri-las em valores comuns - supostamente universais -as igualaria. No mesmo instante, ao incentivar a busca por autonomia em face da sociedade, forjaria um novo tipo de individualidade que diferencia.

Ao apresentar o caso dos Estados Unidos, "onde o individualismo seria de outro tipo" quando comparado à França, "a escolarização ganhou razões sociais e de governabilidade" e onde o processo se voltou para a afirmação de um vínculo forte entre o indivíduo e a sociedade no "sentido coletivo de missão e progresso"(BURGOS, 2014). Por isso, Dewey, nome principal da escola progressista estadunidense, acreditava que a escola deveria ser considerada como "uma comunidade em miniatura" e que deveria iniciar a criança "numa pertença efetiva através da autodisciplina do sujeito".

Partindo de outras premissas sociais e políticas, mas com o mesmo ponto de chegada, ou seja, uma escola democrática, o socialista Gramsci a afirmava, ainda de acordo com Burgos, "como uma escola unitária, uma escola criadora, capaz de expandir a personalidade, tornada autônoma e responsável, mas com consciência moral e social sólida e homogênea" (op.cit. p.114).

Desse modo, podemos assegurar, com uma boa dose de certeza, que a ideia de uma escola mais democrática, que ajudasse a criar indivíduos autônomos, criativos e responsáveis coletivamente era, tanto para as tendências políticas de cunho mais liberal como para os socialistas - ao menos em sua versão mais progressista -, o ideal a ser alcançado.

Contudo, a consecução desse ideal passava pela tensão entre o indivíduo e seu papel na sociedade. A responsabilidade coletiva estava sempre colocada e 
com ela havia a necessidade de um tratamento igualitário para que todos pudessem aprender "valores universais" e se comprometessem com o coletivo.

No entanto, esse movimento acabou por produzir, nas escolas, a despeito da aposta no fortalecimento da individualidade, certa obliteração do sujeito em face do papel de aluno. Nas democracias mais longevas, como na França, como vimos, "o sujeito por trás do aluno" foi deixado de lado justamente em nome do ideal de igualdade e do aprendizado dos valores comuns, como apontamos acima.

Mas esse estado de coisas mudou hoje no campo da educação, segundo Burgos, porque há necessidade de se conhecer a realidade do aluno para além dos muros da escola. Não temos dúvidas de que essa necessidade se impõe como obrigação à instituição escolar no sentido de que ela precisa conhecer o sujeito por trás do aluno para que possa responder de maneira satisfatória aos novos desafios sociais que se colocam em seu caminho.

$\mathrm{O}$ autor apresenta o caso brasileiro para ilustrar essa nova perspectiva. Entre nós, a "escola de massas" só começa mesmo a se consolidar a partir dos anos de 1970, com o projeto de "modernização autoritária" do regime militar (1964-1985) e a sua necessidade de mão-de-obra qualificada para o mercado que então se expandia. Assim, o aluno brasileiro é convocado para ajudar a desenvolver o "Brasil grande" e, para isso, deve desempenhar o papel de força de trabalho da modernização da sociedade. Prevalece, seguramente, um modelo de escola também autoritário, que não vê o seu aluno como um sujeito. Contudo, não temos dúvidas que o processo de alargamento da escola e da escolaridade, mesmo sob os auspícios dos governos militares e voltados para a lógica do mercado, provocaram mudanças importantes no caráter da escola pública no Brasil.

Esse processo acompanhou a própria dinâmica da sociedade brasileira e sua luta por mais democracia. Foram a Constituição de 1988 e o Estatuto da Criança de 1990 que promoveram, segundo Burgos, uma "profunda mudança na concepção da criança na ordem jurídica do país" (ibid., p. 11). Com eles, passa a vigorar a "doutrina da proteção integral da criança" que, por sua vez, muda completamente o lugar das crianças e adolescentes na sociedade brasileira, repercutindo no processo de "formação do aluno" entre nós.

Com tal mudança, as crianças e adolescentes passam a ser centrais no processo de democratização da própria sociedade e seu direito à educação e à escola passa a ser uma "via incontornável do processo de socialização das novas 
gerações" (op. cit., p. 12). Há uma ressalva importante feita por Burgos no que concerne a especificidade do processo de escolarização de nossas novas gerações brasileirase sobre a formação do aluno:

[...] se em contextos de democracia mais longevas o grande desafio ora colocado é permitir que o sujeito por trás do aluno seja levado em conta pela escola [...] no Brasil, o quadro é diverso, estando em jogo o desafio de se transformar a criança/adolescente em aluno (BURGOS, 2014, p. 12).

Reportando-se ao estudo feito por Benjamin Moignard, que comparou uma escola localizada próxima a uma favela brasileira a uma escola na periferia de Paris, Burgos, concorda que, no Brasil, falta uma delimitação clara entre os muros da escola, a rua e o mundo do aluno. Essa indiferenciação cria, entre outras coisas, uma certa confusão dos papeis sociais de professores e alunos gerando formas de relações "personalistas e assimétricas" que deixam as crianças a mercê do paternalismo e idiossincrasias dos profissionais da escola e de outras formas de violência.

O desafio, portanto, no nosso caso, é fazer com que a criança verdadeiramente se transforme em aluno ao ingressar na escola afastando, assim, os prejulgamentos, as expectativas de sucesso ou fracasso baseadas em sua origem social e territorial. Ao contrário do processo francês - onde o desafio é reconhecer o mundo da criança por trás do aluno -o processo brasileiro precisa reconhecer e promover o aluno a partir da criança.

Por isso, criar ações que estruturem um ambiente de acesso igual à educação para todas as crianças e adolescentes é fundamental para que a escola possa, de fato, disputar um lugar no mundo do aluno e, com isso, construir, o que Burgos (2014) chama de "um clima de confiança no projeto escolar", capaz de assegurar a permanência dos alunos de origem popular na escola.

De outro lado, Burgos utiliza o conceito de "educabilidade" do sociólogo argentino Néstor López para colocar "luz sobre a relação da escola com o mundo do aluno" (ibid., p. 16). Segundo López, a partir do conceito de educabilidade pode-se pensar em que "tipo de recursos, atitudes ou predisposições aos quais as crianças/adolescentes deveriam ter acesso para estar na escola de maneira exitosa e que condições sociais permitiriam a elas ter acesso a tais recursos".

A importância do conceito reside no seu grau de explicação das responsabilidades sobre a transformação da criança em aluno. Isso porque evita "jogar o peso" sobre a escola unicamente ou sobre a família apenas. Assim, 
podemos determinar que é com a relação entre esses agentes socializadores que se define o processo de transformação da criança em aluno. Por isso, a necessidade de outras políticas públicas que apoiem e afirmem o trabalho da escola e de seus profissionais. Contudo, López adverte que a necessidade do apoio de políticas sociais mais amplas não exime a escola da responsabilidade de conhecer o seu aluno.

Desta forma, Burgos nos ajuda a olhar para o lugar que o sujeito social ocupa, observa o seu território e como esse sujeito traz as práticas desse território inscritas em si. O conceito de mundo do aluno permite ainda fazer a crítica a uma série de concepções e estereótipos e, ao mesmo tempo, confrontar outro conceito construído a partir do senso comum escolar e muito em voga nas escolas: o conceito de "famílias desestruturadas".

O discurso de que as famílias mais pobres são desestruturadas assumiu destaque no "senso comum escolar" e caracteriza o modo pelo qual a escola, e grande parte de seus profissionais, qualificam e classificam as famílias mais pobres. Há uma verdadeira cristalização de certo tipo de visão sobre o mundo do aluno, que acaba por constituir uma "lente" através da qual a escola passa a observar as famílias e seus filhos, qualificando-as e hierarquizando-as (RESENDE, 2009; BURGOS, 2008; NOGUEIRA, 2005; THIN, 2002; LAIRE, 1998).

A concepção de que as famílias mais pobres são desestruturadas está baseada em ideais que envolvem o pressuposto de que os pobres têm muitos filhos, que pais e mães praticam condutas desviantes e mesmo criminosas, há abandono das crianças, falta de cuidados e negligência com a educação escolar dos filhos (BURGOS, 2008). Essas ideias ficam patentes nas falas de muitos professores, diretores e outros agentes educacionais de escolas públicas, sobretudo as localizadas nas favelas cariocas. No entanto, não é essa a realidade apresentada por pesquisas recentes que tratam da relação das famílias mais pobres com a escola e a escolarização de seus filhos e filhas (LAHIRE, 2008; BATISTA; SILVA, 2013; BURGOS, 2014).

Em pesquisa realizada em uma das maiores das favelas da cidade, Burgos (2012) apresenta uma série de dados sobre a população local que contradiz a ideia de família desestruturada e ainda confirma o interesse das famílias mais pobres pela escola. Um dos indicadores construídos para avaliar o grau de importância da 
escola na vida familiar, por exemplo, diz respeito à "presença da escola no cotidiano doméstico do aluno" (ibid., p. 39).

Segundo o levantamento, realizado a partir de um survey, o percentual considerado alto e muito alto das famílias que dizem conversar com as crianças sobre a escola soma $81,5 \%$ para as crianças do primeiro segmento e $68,6 \%$ para as crianças que frequentam o segundo segmento do ensino fundamental. Isso demonstra que a escola é uma instituição presente no cotidiano das famílias e que se coloca como tema fundamental na interação entre os pais e seus filhos.

Outro resultado interessante apresentado nessa mesma pesquisa diz respeito à medição do grau de "presença do responsável pedagógico na escola do estudante". Na média, apenas $7,1 \%$ dos entrevistados poderiam ser considerados como ausentes; $26 \%$ como tendo presença baixa; $60,4 \%$ como tendo presença média; e 6,5\% presença alta (BURGOS, 2012, p. 40).

Desse modo, a ideia da "omissão parental", na verdade, é um "mito" (LAHIRE, 2005) e carrega consigo os preconceitos arraigados a partir de uma determinada concepção de família. Tal concepção foi herdada do início do século passado e não leva em conta as profundas mudanças pelas quais as famílias brasileiras passaram nas últimas décadas. Não leva em conta, ainda, as novas formas de arranjos familiares que se processam na sociedade brasileira: mães que cuidam da família sozinhas ou que assumem a condição de "chefe da casa"; pais que cuidam sozinhos dos filhos; famílias que agregam gerações diferentes no mesmo espaço; famílias ampliadas nas quais o que conta não são apenas os laços consanguíneos, mas também a solidariedade de amigos e vizinhos; e famílias formada por casais homoafetivos (ROMANELLI, 2013).

Isso significa que as famílias - e não apenas as mais pobres - estão cada vez mais distantes dos padrões tidos como "normais", presentes em livros de etiqueta, livros didáticos e de moda dos anos de $1950^{18}$.

A grande questão é que, em muitos momentos, a ideia de famílias desestruturadas é transformada em discurso corrente em escolas e secretarias de educação, e passa a explicar quase todos os problemas de aprendizagem e de relação entre escolas e famílias, sobretudo nos territórios mais pobres. Isso, por sua vez, impede que se desenvolva uma relação de maior proximidade entre

\footnotetext{
18 Conselhos de revistas feministas dos anos 50 e 60 . Disponível em http://www1.folha.uol.com.br/folha/pensata/ult528u42.shtml. Acesso outubro/2016.
} 
escolas e famílias e, por conseguinte, de compreensão dos desafios que a educação escolar de crianças pobres carrega nos territórios vulneráveis.

Resende (2009) nos ajuda a compreender essa questão quando cita uma pesquisa realizada pelo IBOPE, encomendada pela Revista Nova Escola em 2007. Nela, nada mais, nada menos do que $77 \%$ dos 500 professores entrevistados afirmaram que o maior problema da escola era a ausência dos pais na educação escolar de seus filhos. $\mathrm{Na}$ mesma pesquisa, $70 \%$ dos professores apontaram que o segundo maior problema enfrentado por eles nas escolas era a desmotivação dos alunos e $67 \%$ afirmaram que, ao lado dessa desmotivação, estava a indisciplina como causadora do fracasso escolar.

Assim, os alunos e alunas são responsabilizados pelos maus resultados escolares, como o fraco desempenho, o abandono e a reprovação. As crianças, também, são caracterizadas como "desinteressadas", "indisciplinadas” ou mesmo como incapazes de aprender.

Como pode ser observado, há uma enorme distância entre o mundo escolar e o mundo do aluno. A escola não considera a vida real e concreta das crianças que recebe todos os dias, por isso, quando trabalha a partir de valores e ideias que são muito mais afeitas a um "aluno ideal", passa a interpretar aqueles que são reais como desviantes, desinteressados e indisciplinados. Essa, por exemplo, é uma das armadilhas que se interpõem no caminho das relações entre escolas e famílias.

Conhecer melhor o mundo do aluno, sua família, é fundamental para transformar as crianças de origem popular, que cada vez mais ingressam e reivindicam a escola, em alunos com direito a educação de qualidade.

\section{4}

\section{As relações armadilhadas}

Pedro Silva (2003), ao falar da necessidade de se construir uma escola mais democrática, verdadeiramente aberta a todos e intercultural, afirma ser inevitável que se coloque a questão das "relações armadilhadas" entre escolas e famílias como ponto fundamental de um processo que queira aproximar ambas. Embora fale da realidade portuguesa, nos parece pertinente trabalhar com a noção de relações armadilhadas para definir as relações entre as escolas e as famílias no contexto da Maré. É claro que não defendemos aqui uma transposição automática 
de uma realidade à outra, mas, seguramente, as categorias de análise e a pesquisa empírica de Pedro Silva podem nos ajudar na compreensão de nosso objeto.

O que o autor português chama de "armadilhas" pode ser interpretado como “ciladas" (ibid., p. 378) que são, na verdade, perigos que se colocam no caminho de uma relação qualitativamente melhor e mais próxima entre as escolas públicas e seu público.Silva situa as relações entre escolas e famílias dentro de uma perspectiva que leva em consideração suas diferenças socioculturais e as dificuldades daí advindas. Para o autor, a diferença entre a cultura escolar, de um lado, e a cultura das famílias, de outro, acaba por produzir situações relacionais que se não forem observadas com a devida atenção - e evitadas, por óbvio podem se transformar em verdadeiras armadilhas.

Por isso, o autor reivindica o estudo teórico-prático das muitas dificuldades que se interpõem entre escolas e famílias e que colaboram para o distanciamento entre essas instituições socializadoras. Isso já seria uma forma de evitar e "desarmadilhar" problemas futuros que se interpõem entre escolas e famílias.

$\mathrm{O}$ autor cita algumas dessas armadilhas em seu trabalho a partir das escolas portuguesas. Dentre elas, a que nos parece mais pertinente para nossa discussão é a do "o duplo efeito de pigmaleão" (ibid., p. 385). Ela diz respeito ao fato de os professores construírem suas expectativas, negativas ou positivas, com relação aos alunos, a partir do julgamento da presença ou não dos pais e responsáveis na escola. Por sua vez, a partir do mesmo critério, os responsáveis podem assumir o julgamento da escola de que são bons ou maus pais. Em ambos os casos, segundo Silva, os "educandos tenderão a interiorizar as expectativas (de pais e professores) agindo em conformidade" (ibid.).

Por isso, adverte Silva, é preciso evitar tais armadilhas, e isso só se faz a partir de informações a respeito dos "perigos que espreitam" a relação (ibid., p. 378). Para entender as origens dessa relação armadilhada, o autor parte de um estudo etnográfico em três escolas de ensino básico em Portugal. Seu objetivo é compreender a influência das origens sociais - notadamente o pertencimento a uma classe social e a questão de gênero - na interação entre os profissionais da escola e as famílias.

O autor situa, ainda, essas relações no contexto social mais amplo das transformações ocorridas na sociedade portuguesa, afirmando que a escola não pode ser vista como um ente isolado das relações socioculturais. Insiste que é 
preciso observar a relação escola-família a partir dos níveis macro, meso e microestruturais, que vão desde a formulação das grandes políticas públicas que explicitam as relações mais gerais entre escola e sociedade, passando pela organização do trabalho escolar até a organização do trabalho pedagógico em sala de aula.

Segundo Pedro Silva, a maior das armadilhas é a relação escola-família se transformar em um meio de reprodução das desigualdades sociais e culturais. Isso pode ocorrer quando a escola se mantém como uma instituição multicultural devido ao seu público - não conseguindo se transformar em uma instituição intercultural onde as diferentes culturas, englobando a de professores e familiares, sejam vistas como iguais e mantenham relação horizontal.

Esta é a tese principal do trabalho de Pedro Silva: as relações entre escolas e famílias só deixam de ser armadilhadas quando se estabelece uma verdadeira escola intercultural, ou seja, onde a cultura das famílias, sobretudo das mais pobres, deixa de ser vista como subordinada e exótica e é reconhecida como parte importante do processo educacional e social, tal qual a cultura escolar.Só assim, poderia haver um verdadeiro diálogo entre escola e família, não apenas uma relação vertical e hierárquica como ocorre hoje.

O autor enxerga a escola como o "lado mais forte" e, por isso, é justamente dela que deve partir o movimento em direção a uma relação onde a instituição escolar não é apenas o abrigo de culturas diversas e hierarquizadas, de acordo com as origens sociais, de gênero e religiosas, mas sim um lugar, onde as diferentes culturas se comuniquem e complementem. Onde, de fato, a escola seja uma instituição intercultural. Uma escola assim poderia colaborar para uma maior democratização da sociedade, aposta o autor.

\section{5}

\section{O lugar de moradia}

O lugar, o território, a vizinhança são os espaços concretos onde escolas e famílias vivenciam suas relações e onde se expressam materialmente as contradições inerentes à sociedade e que incidem justamente sobre escolas e famílias.Nossa principal referência para tratarmos das questões ligadas à influência do lugar de moradia sobre as pessoas e sobre as relações entre escolas e famílias é Carolina Flores (2008). A autora chilena investiga os efeitos da 
concentração da pobreza sobre os resultados escolares de crianças que vivem em locais pobres na cidade de Santiago do Chile.

Sua abordagem combina a "teoria dos efeitos de bairro" e o enfoque de "ativos, vulnerabilidade e estrutura de oportunidades". Particularmente, os conceitos de "geografia subjetiva das oportunidades" e de "geografia objetiva das oportunidades" nos serão muito úteis. Isso porque esses conceitos nos ajudam a dar conta da realidade que estudamos ao abordar nosso objeto de estudos: as relações escolas-famílias-vizinhança na Favela da Maré.

Antes, porém cabe uma explicação e um ajuste: Flores trabalha com o conceito de "efeito-bairro" ao estudar as implicações na vida escolar de crianças que habitam em espaços - bairros - marcados pela pobreza no Chile. Contudo, embora a autora não explicite de maneira clara o seu conceito de bairro - em alguns momentos chega a usar também o conceito de comunidade -, a definição que Flores faz sobre as condições de vida, moradia, interação social entre pessoas e instituições e as relações que se desenvolvem no espaço são compatíveis com os conceitos de território e vizinhança por nós definidos neste trabalho.

Assim, segundo Flores, indivíduos que moram em lugares onde há concentração espacial da pobreza têm menos chances educacionais dos que aqueles que não vivem em condições semelhantes (ibid., p.145). Isso ocorre, segundo a autora, porque o isolamento de populações em áreas pobres - por conta da própria dinâmica do capitalismo, que classifica e limita os grupos sociais em determinadas áreas da cidade a partir do poder econômico - gera um determinado ethoscultural de classe que afasta os mais pobres da cultura predominante nas escolas. Tal fato ocorre justamente porque a escola privilegia a cultura das classes mais ricas da sociedade (ibid.). Por outro lado, a produção desse ethos de classe reforça e legitima comportamentos particulares, hábitos, valores e crenças de cada classe social o que as afasta ainda mais umas das outras.

Apesar de retratar esse fenômeno na cidade de Santiago, é inevitável não fazermos um paralelo com a cidade do Rio de Janeiro. Muito embora o Rio de Janeiro seja representado como uma cidade mais permeável ao intercâmbio social, com a exaltação da sociabilidade do carioca, o que temos, na verdade, é um processo semelhante ao que ocorre no Chile em termos de apartamento das classes sociais. Mesmo que no Rio de Janeiro as classes sociais convivam em territórios 
muito próximos, como é o caso dos bairros de classe média alta, que dividem o território com favelas, caso da Gávea e da Rocinha, por exemplo.

Quando se propõe a explicar os mecanismos que geram o efeito bairro, Flores utiliza três elementos chave: a) os "mecanismos de controle ou eficácia normativa; b) as fontes de informação; c) a estrutura das oportunidades locais" (ibid., p. 149).

No que tange aos mecanismos de controle ou eficácia normativa, de acordo com a autora, temos o grau de consenso em torno das normas e da supervisão das crianças por parte dos adultos de um dado lugar. A eficácia normativa define um contexto de desenvolvimento social positivo, sendo fundamental para a socialização das crianças, pois elas, quando moram em territórios onde as regras são claras, legítimas e onde os adultos exercem vigilância sobre sua conduta, tendem a se afastar de comportamentos de "risco" 19 . Caso contrário, ou seja, em um cenário onde a eficácia normativa é fraca, as chances de as crianças adotarem comportamentos desviantes é bem maior.

No que concerne à questão das informações, os mecanismos socializadores dizem respeito ao modo como os indivíduos se adaptam a essas informações e como as utilizam como guia de comportamento. Com base em autores como Jenks e Mayer, Flores ressalta o conceito de "influência do semelhante" (ibid., p.150), que supõe um processo de "contágio" ou difusão de comportamento de um indivíduo a outro.

A concentração de determinados comportamentos - como evasão escolar ou condutas de risco - em territórios pobres ou vulneráveis tende a se espalhar quando outros mecanismos - como a vigilância dos adultos - falham. Isso se agrava quando "os modelos de papel social" são frágeis ou inexistem modelos de eficácia e sucesso no mundo do trabalho que possam ser seguidos.

Em contextos pobres, os vínculos com o mundo do trabalho formal são frágeis e limitados, o que dificulta a projeção nos mais jovens de imagens de sucesso a serem seguidas. Dito de outra maneira: não ter adultos próximos com sucesso no mundo formal do trabalho é um fator dificultador das relações dos

\footnotetext{
${ }^{19}$ Flores destacada ainda dois mecanismos ligados ao controle social: a eficácia coletiva que é ativada pelos vizinhos para conseguir um bem comum, como no caso da educação das crianças, onde se partilham crenças e desejos; e o "conhecimento geracional" onde os pais conhecem em maior profundidade os amigos de seus filhos e assim podem controlá-los melhor.
} 
mais jovens com o mundo do trabalho e pode ser um ponto de inflexão para condutas consideradas marginais.

Seguindo a linha de análise que trata do efeito-bairro, Flores trabalha com dois conceitos, a partir de Galter e Killer, potencialmente úteis para tratarmos das relações entre escolas e vizinhanças: a geografia objetiva de oportunidades e a geografia subjetiva de oportunidades.

O conceito de geografia objetiva das oportunidades pode ser entendido como relacionado à estrutura, à qualidade e ao acesso a sistemas sociais, mercados e instituições presentes no bairro com as quais os indivíduos podem contar. De maneira complementar, a geografia subjetiva de oportunidades tem a ver com os "valores, anseios, preferências e percepções subjetivas acerca das oportunidades e dos potenciais resultados da tomada de decisões" dos indivíduos, levando-se em consideração as oportunidades objetivas oferecidas no seu território (ibid., p. 153).

A construção da percepção acerca das oportunidades a serem aproveitadas passa por um "filtro de percepção das oportunidades disponíveis", que é formado a partir da socialização de cada indivíduo em seu contexto. Assim, cada um avalia a importância e a pertinência de cada oportunidade segundo sua experiência prévia. Mais uma vez, o contexto, o bairro, para usarmos o conceito de Flores ou, em nosso caso, a vizinhança e o território, é de suma importância para o conjunto de decisões que cada um deve tomar ao longo de sua vida.

Flores, contudo, faz uma ressalva que vale a pena ser considerada: ela insere o conceito de "agência humana" para contrabalançar o poder do contexto. A ideia de agência humana tem a ver com a capacidade do indivíduo de regular a própria vida, de resistir e reagir ao território e, ainda, tem a ver com a capacidade de decidir por si, mesmo reconhecendo-se que tais decisões são condicionadas, ao menos em parte, pelo contexto social.

Desse modo, o conceito de agência humana propicia o controle de certo viés determinista, que poderia decorrer da adoção de um referencial pautado na determinação absoluta do território sobre a vida das famílias e indivíduos.Na verdade, o que temos quando tratamos do efeito-bairro ou do efeito-vizinhança é a constatação de influências múltiplas entre instâncias de socialização distintas e agentes sociais que, no entanto, se comunicam, interpelam e complementam.

Desse modo, o contexto social e geográfico, o território, é um dos elementos mais importantes de socialização dos indivíduos. O território ajuda a construir os 
hábitos, as crenças e atende ou não as necessidades, que circulam através dos indivíduos e grupos. É no território que se formam redes sociais locais onde os indivíduos se inserem, criando vínculos, afetos e memórias que serão importantes para a formação dos "filtros de percepção das oportunidades" descritos acima.

\section{6 \\ O conceito de território}

O território representa mais um elemento na composição do campo de relações formado em volta de escolas e famílias. Nele, se materializam as complexas trocas e intercâmbios culturais entre essas instituições socializadoras e, ao mesmo tempo, onde as influências mútuas se fazem presentes, bem como as disputas e tensões.

O próprio território constitui-se em instância de socialização, já que nele os indivíduos entram em contato com a cultura, a tradição, os usos e os saberes práticos criados e circunscritos a um lugar específico. Assim, não podemos falar de indivíduos, grupos, comunidades e instituições locais sem inseri-los em um espaço geográfico concreto, ou seja, o território (HAESBAERT, 2010).

Nossa primeira constatação, no entanto, é a de que o conceito de território é definido de forma ainda imprecisa nas pesquisas educacionais. Sua definição não é clara nos trabalhos que tratam das relações entre escolas, famílias e vizinhança. Isso, é verdade, se repete não apenas no campo da educação.

O geógrafo Haesbaert (2010), por exemplo, ao fazer o levantamento do uso do conceito de território identifica diferentes maneiras de definição dependendo do campo científico em que ele é usado. Assim, segundo o autor:

Enquanto o geógrafo tende a enfatizar a materialidade do território, em suas múltiplas dimensões [...] que deveria incluir a interação sociedade-natureza, a Ciência Política enfatiza sua construção a partir de relações de poder (na maioria das vezes, ligadas à concepção de Estado); a Economia, que prefere a noção de espaço à território, percebe-o muitas vezes como um fator locacional ou como uma das bases da produção (enquanto "força produtiva"); a Antropologia destaca sua dimensão simbólica, principalmente no estudo das sociedades ditas tradicionais [...]; a Sociologia o enfoca a partir de sua intervenção nas relações sociais, em sentido amplo, e a Psicologia, finalmente, incorpora-o no debate sobre a construção da subjetividade ou da identidade pessoal [...] (ibid.,p. 37).

Chama à atenção o fato do campo da educação não ter elaborado uma definição mais precisa sobre o que se entende por território stricto senso. O que temos é uma apropriação de conceitos ligados, sobretudo, à sociologia urbana que 
são incorporados às pesquisas educacionais. Talvez isso explique o intercâmbio mais ou menos fluído entre os conceitos de território, bairro e vizinhança que podemos observar nos trabalhos sobre as relações entre escolas, famílias e o lugar onde tais relações se desenvolvem.

É o que pode ser visto, por exemplo, quando Érnica e Batista (2012) comentam algumas pesquisas clássicas no campo da educação sobre o tema:

As expressões "efeito de lugar" (BOURDIEU, 1997), "de segregação" ou "de território" (MAURIN, 2004), "de vizinhança" (MALOUTAS, 2011) designam o impacto do local de residência e das características sociais de sua população sobre "as condições de vida e a mobilidade social dos habitantes" (MALOUTAS, 2011, p. 288). Designam, ainda, mais especificamente, o impacto do território sobre os destinos escolares dos indivíduos (MAURIN, 2004, p. 642).(ÉRNICA; BATISTA, 2012.)

O fato é que esses conceitos, efeito de lugar, território, bairro e vizinhança, carregam consigo a ideia de que o espaço geográfico onde se situa a moradia afeta a vida e as oportunidades socioculturais, econômicas e escolares de seus habitantes. Nesse sentido, concordamos com Milton Santos quando diz que: "o valor do indivíduo, depende, em larga escala, do lugar onde está" (SANTOS, 2012, p. 139) ${ }^{20}$.

Para efeito do presente trabalho, definimos o território como um espaço geográfico onde as relações de poder, material e simbólico, se dão (HAESBAERT, 2010), onde relações "complementares e conflitantes" são tecidas (SANTOS, 2012; HAESBAERT, 2000) e onde essas relações se expressam, ao mesmo tempo em que reagem sobre o território (LEFEBVRE, 2006), condicionando-o e afirmando, até certo grau, condições específicas de vida e possibilidades para grupos e indivíduos.

Diante do exposto, reafirmamos que a influência do território precisa ser considerada quando se trata da educação escolar, pois a qualidade e a forma como se dão as relações entre escolas e famílias são afetadas pelo local onde se inserem essas duas instâncias de socialização das crianças. Apesar de os mecanismos desse processo ainda não estarem totalmente esclarecidos, muitos autores concordam com essa afirmativa (FLORES, 2008; ALVES, BONAMINO, LANGE, 2010; RIBEIRO, KOSLINSKI, 2010; CRISTOVÃO, SANTOS, 2010; SOARES,

\footnotetext{
${ }^{20}$ Em uma sociedade hierarquizada como a sociedade capitalista, os territórios também se encontram em uma relação de hierarquia. A marca do território se inscreve nos agentes sociais e os coloca diante da cidade em determinadas posições de maior ou menor prestígio, o que, muitas vezes, define os caminhos possíveis de serem percorridos.
} 
RIGOTTI, ANDRADE, 2010; RETAMOSO, KATZMAN, 2010; LOPEZ; 2010; LAHIER, 2008; THIN, 2006; BURGOS, 2010; BOURDIEU, 2008).

É preciso esclarecer também que consideraremos, em nosso trabalho, dois aspectos do conceito de território: o primeiro diz respeito ao fato dele designar um espaço demarcado, definido dentro da cidade, em relação hierárquica com outros territórios que formam, frente aos demais, "espaços homogêneos"; o segundo diz respeito ao fato de que, dentro de cada território, dentro de cada "espaço homogêneo", existem divisões que se configuram como "subterritórios".

Sobre o primeiro aspecto do conceito de territórios, ou seja, como espaços da cidade, que se relacionam de maneira hierárquica e como espaços homogêneos, concordamos com Burgos (2005) quando ele afirma a evolução histórica da cidade do Rio de Janeiro a partir de um processo de fragmentação do espaço geográfico em territórios que se diferenciam a partir de padrões econômicos, culturais e sociais bem marcados ${ }^{21}$. Esse processo, na verdade, acontece em todos os cantos da cidade, sejam eles mais antigos ou mais recentes, como é o caso da Barra da Tijuca, por exemplo, por onde a cidade mais tem se expandido recentemente e por onde o mesmo processo de fragmentação e hierarquização do território se manifesta.

Isso fica mais claro, ainda, quando observamos determinadas áreas da cidade do Rio de Janeiro, como a Zona Sul, onde convivem territórios ricos e pobres, como é o caso da Favela da Rocinha e os condomínios de luxo, localizados no bairro da Gávea ${ }^{22}$. Ali, todos sabem bem quais são as fronteiras desses territórios e as interdições aos moradores e pessoas que circulam por eles. Todos reconhecem os códigos territoriais, seus usos e maneiras de se comportar e agir.

Cada um desses espaços aparece para o outro como espaços homogêneos que têm valores diferentes no "mercado de territórios" na cidade. Morar em um ou

\footnotetext{
${ }^{21}$ As relações territoriais no Rio de Janeiro foram marcadas pela hierarquização e pela subordinação nos anos de 1960, substituída depois por uma relação de "escassez da cidade". Segundo este conceito há uma baixa capacidade do Estado e da sociedade de universalizar regras e valores que criem um espaço público compartilhado. Isso gera fragmentação e territorialização. É o caso, por exemplo, das favelas de um lado e dos condomínios de luxo de outro. Mesmo aqueles que se encontram próximos fisicamente mantêm suas fronteiras bem fechadas, caso como a Gávea e a Rocinha, por exemplo.

${ }^{22}$ A Gávea aparece, segundo o Instituto Pereira Passos, como o bairro da cidade com o melhor índice de desenvolvimento humano $(0,970)$; quando observamos a Favela da Rocinha constatamos que ela ocupa o $120^{\circ}$ lugar dentre os 126 bairros da cidade no que se refere ao mesmo indicador $(0,732)$.
} 
outro dos territórios citados acima produz, embora não seja essa uma regra absoluta, efeitos concretos nas chances de aproveitamento ou não de oportunidades de desenvolvimento socioeconômicos para cada um de seus habitantes.

Isso também se aplica à Favela da Maré, pois ela também é vista e representada como um espaço homogêneo em relação aos outros territórios da cidade e essa representação, assim como no caso da Rocinha, tem sempre como referência ou parâmetros os territórios mais ricos da cidade.

A partir desse tipo de comparação, a Maré é apontada como o território da violência, da carência, da pobreza e do fracasso, o que lhe confere um significado negativo. O resultado é que ser identificado como morador da Maré pode trazer consequências negativas para a vida dos indivíduos que lá habitam. Esse fato pode gerar, por exemplo, dificuldades de se conseguir um emprego ou mesmo receber um serviço público ou privado, como é o caso dos serviços de correios, entregas, limpeza, iluminação e segurança.

Porém, há um segundo aspecto do conceito de território que consideramos de suma importância e que precisa ser esclarecido. Dentro de cada território homogêneo, existem subdivisões ou subterritórios que também precisam ser observados com atenção, pois produzem efeitos importantes para os grupos e indivíduos que os habitam.

Por exemplo, a Favela da Rocinha e os condomínios de luxo da Gávea, quando vistos mais de perto, revelam que aquilo que aparece como espaços homogêneos, na verdade, contêm em si subdivisões importantes. Os moradores, agentes públicos, mercado e o próprio Estado, reconhecem essas subdivisões territoriais e agem em conformidade com as características deles. Desse modo, na Rocinha existem pelo menos trinta e duas subáreas reconhecidas como tais (BURGOS, 2012). Cada um desses espaços guarda especificidades importantes que marcam a vida e as relações entre pessoas e instituições locais.

A Maré também possui subdivisões territoriais internas bem marcadas. Existem limites e "fronteiras", tanto simbólicas quanto geográficas, construídas ao longo da formação histórica da Maré, que hoje lhe dão as dimensões e o formato atual $^{23}$. Os moradores as conhecem bem, sendo essas fronteiras reafirmadas de

\footnotetext{
${ }^{23}$ Mais adiante, no capítulo 6, falaremos mais detalhadamente das divisões territoriais internas da Maré.
} 
acordo com as relações, sempre cambiáveis, com a cidade e com os próprios moradores, e impactadas pela dinâmica das disputas territoriais entre grupos criminosos armados e a polícia.

Desse modo, trabalharemos com o conceito de território quando nos referimos à Maré a partir de dois aspectos, ou seja, um território homogêneo para "fora”, que carrega uma representação negativa e, ao mesmo tempo, um território heterogêneo que possui subterritórios que se diferenciam e formam configurações específicas que podem influir de maneira diferente sobre os indivíduos, grupos e instituições.

\subsection{1}

\section{Comunidade ou favela?}

Para fugir do estigma de serem chamados de "favelados", termo considerado pejorativo para muitos, vários moradores de favelas cariocas adotam o conceito de "comunidade" para caracterizar seu lugar na cidade (DINIZ, BELFORT, RIBEIRO, 2010). Assim, a comunidade - palavra usada, inclusive, pelos meios de comunicação para definir a favela - passa a competir e mesmo substituir o termo favela, além de conviver de maneira ambígua com ele como definição do "espaço dos pobres" na cidade. Essa substituição ou intercâmbio entre comunidade/favela não é algo elaborado ou racionalizado como pode parecer à primeira vista, mas sim um senso prático de proteção ou uma tentativa de "atenuar" os efeitos negativos de ser identificado com a favela, ou como um "favelado".

Contribui também para o uso do termo comunidade, por mais paradoxal que possa parecer, o fato de os moradores das favelas construírem redes de solidariedade e de ajuda mútua - o "bater a laje”, em que os vizinhos se ajudam na construção de suas casas; o cuidar das crianças compartilhado pelas mães; a ajuda aos idosos e doentes, as festas nas ruas, etc. - que geram estabilidade e segurança diante de uma vida sempre atribulada e marcada pela escassez.

Assim, por mais contraditório que possa parecer, por conta das questões ligadas à violência, especialmente a praticada pelos grupos criminosos que dominam os territórios nas favelas, há, sem dúvida, um sentimento de comunidade forte na Maré, ligado à sensação de pertencimento e proteção mútua entre vizinhos e amigos (ibid.). 
Diante do exposto acima, adaptamos, para designar os territórios com os quais viemos trabalhando, em especial à Maré, o termo "comunidades/favelas". Isso porque, essa forma atende aos moradores que nomeiam seu lugar de moradia como "comunidade", mas também denuncia a tensão presente no termo favela, que carrega um peso histórico considerável e não pode ser esquecido. Este último termo, favela, é o que mais repercute no imaginário social e ainda serve de parâmetro nas relações com a cidade.

Parte fundamental do trabalho das escolas públicas diz respeito a ter de considerar a divisão das comunidades/favelas da Maré como mais um dos elementos fundamentais de sua formação e dinâmica interna que podem interferir em seu trabalho. Esses espaços, espécies de subterritórios, são marcados por diferenças entre si e também podem ser agrupados segundo classificações que levam em conta variáveis como renda, equipamentos públicos, escolas e postos de saúde, centros esportivos e culturais, creches, associações de moradores, tamanho e variedade do comércio local, por exemplo ${ }^{24}$.

Por último, o conceito de vizinhança será usado sempre que nos referimos ao local mais próximo do prédio escolar. Por estar em contato mais direto com o trabalho da escola, a vizinhança, pode afetá-la mais significativamente, tornandose um elemento de mediação entre escolas e famílias. Estão incluídas aí, além das casas próximas às escolas ${ }^{25}$, as ruas, as praças, as instituições religiosas, as empresas, os pequenos negócios, as instituições da sociedade civil, como ONGs, as Associações Comerciais, as Associações de Moradores, entre outras, que compõem um conjunto de instituições, agentes e lugares que também pode incidir sobre o trabalho escolar, porém, em uma escala de proximidade maior que o território.

Por isso, para efeitos deste trabalho, quando pensamos no lugar de moradia, pensamos no efeito-vizinhança e nos referimos aos subterritórios, ou seja, às dezesseis comunidades/favelas que compõem o território mais amplo da Maré.

\footnotetext{
${ }^{24}$ No capítulo 6, serão apresentadas as comunidades/favelas que compõem a Maré.

${ }^{25}$ A prefeitura da cidade do Rio de Janeiro calcula a distância de até $1 \mathrm{~km}$ do local de moradia como medida de "vizinhança" para efeitos de matrícula.
} 


\section{7 \\ A metodologia da pesquisa}

É necessário, neste ponto, retomar a questão de minha proximidade com o tema e com o objeto a ser pesquisado, pois, como dito em outro momento, minha relação com a Maré envolve questões profissionais e pessoais de longa data. É corrente nas ciências sociais a afirmação de que a familiaridade com o tema de pesquisa é uma questão fundamental que precisa ser enfrentada.

Segundo Gilberto Velho (2013), durante muito tempo, se preconizou o trabalho isento do pesquisador, que pudesse ser visto como uma "observação neutra". Porém, quando lembramos que o pesquisador também é membro da sociedade - mesmo aqueles que pesquisam outras sociedades carregam consigo referências de suas próprias conformações sociais -, inferimos que a isenção total é uma utopia e pode constituir um erro.

Ainda de acordo com Gilberto Velho, "a realidade [...] é sempre filtrada por determinado ponto de vista do observador, ela é percebida de maneira diferenciada". Com isto, o autor "não proclama a falência do rigor científico no estudo da sociedade, mas a necessidade de percebê-la enquanto objetividade relativa, mais ou menos ideológica e sempre interpretativa" (ibid., p.75).

O enfrentamento dessa questão demanda um esforço contínuo para "estranhar o que é familiar" e adotar uma posição próxima à defendida por Peregrino, que aposta na "proximidade que estranhe e numa distância que não imobilize" (PEREGRINO, 2010, p.27). Acredito que, assim, posso almejar uma proximidade com o tema que não desconsidere minha experiência, mas que, ao mesmo tempo, me permita caminhar para estabelecer minhas conclusões sem prejuízo da objetividade (relativa) que deve ter um trabalho acadêmico.

Neste trabalho, optamos por uma abordagem qualitativa de nosso objeto de estudo, que, de acordo com Minayo (2001, p.21),

[...]se preocupa, nas ciências sociais, com um nível de realidade que não pode ser quantificado. Ou seja, ela trabalha com o universo de significados, motivos, aspirações, crenças, valores e atitudes, o que corresponde a um espaço mais profundo das relações, dos processos e dos fenômenos que não podem ser reduzidos à operacionalização de variáveis.

Entendo esse método como sendo mais apropriado ao meu objeto de pesquisa, pois me permite ter uma aproximação maior com os agentes sociais envolvidos e me proporciona uma maior aproximação com a produção de suas 
lógicas de ação. Assim, a metodologia qualitativa permite captar aquilo que Dauster (2002) afirma ser o principal objetivo do trabalho de campo: "compreender as redes de significados a partir do ponto de vista do outro" ou, ainda, como afirma Zaia Brandão, quando descreve a construção do questionário de pesquisa e diz que o mais importante não é saber se o que o entrevistado responde era verdade ou não, mas sim "compreender a lógica de produção do sentido" (BRANDÃO, 2002, p. 37).

Nesse sentido, pretendemos averiguar quais foram os pontos de encontro e de desencontro entre os agentes envolvidos no PEA/BE e traçar um quadro analítico que permita inferir o sentido dado pelos agentes à política e às suas potenciais ações práticas de aproximação entre escolas-famílias-vizinhança.É importante lembrar, mais uma vez, que o Projeto Bairro Educador foi encerrado em 2013, portanto, há mais de três anos. Por isso, nossa pesquisa trabalhou com base na memória dos entrevistados e com um possível legado de ações deixado pelo Projeto nas escolas atendidas por ele.

Pensando nisso, foram selecionadas duas escolas como campo empírico para realização de entrevistas, observação não participante e acompanhamento das famílias em sua interação com a escola, sobretudo nas reuniões e "encontros sociais" tais como festas, comemorações, dia dos pais etc. A escolha das escolas foi feita a partir dos seguintes critérios: a) participar e não participar do PEA/BE; b) ter resultados que se aproximem da média da cidade a partir do IDEBe da Prova Brasil; c)ofereçam os anos iniciais do ensino fundamental; d) estar localizadas no interior do território da Maré; e, por último, e) condições semelhantes de funcionamento e número de alunos.

\section{8 Instrumentos de pesquisa}

Foram realizadas, ao todo, vinte e duas entrevistas semiestruturadas com professores, diretores, responsáveis pedagógicos, responsáveis da ONG que organizou o PEA/Bairro Educador e gestores da SME-RJ. Para tanto, foram criados roteiros básicos para os diferentes profissionais da escola/educacionais incluindo-se funcionários da ONG e da SME-RJ, para os responsáveis pedagógicos e para os professores. 
Além das entrevistas, a relação escolas-famílias-vizinhança foi investigada por meio de observação e visita às escolas. Utilizamo-nos da técnica do diário de campo, no qual foram registrados os momentos de encontro entre profissionais da escola e responsáveis pedagógicos, o que nos pareceu bem pertinente. Trata-se do registro de encontros formais, como as reuniões periódicas nas escolas, e também de encontros informais, como o momento da entrada e da saída dos estudantes na escola e a participação em festas e outros eventos similares.

A partir da construção do referencial teórico exposto, foi possível desenhar um núcleo central de objetivos para as entrevistas realizadas com os profissionais da escola que podem ser assim resumidos: a) verificar como os profissionais da escola reconhecem as famílias e qual o padrão de comportamento relacional que desenvolvem com elas; b) identificar como a vizinhança é percebida e se, de acordo com os profissionais da escola, ela pode influenciar na relação entre escolas e famílias; c) verificar o grau de conhecimento e participação dos profissionais da escola no projeto Escolas do Amanhã/Bairro Educador; d) reconhecer iniciativas das escolas de aproximação das famílias e da vizinhança,tentando identificar se isso tem a ver ou não com a experiência do PEA/BE.

Quando interrogamos as famílias, procuramos: a) identificar se os responsáveis pelos alunos percebem mudanças nas relações com as escolas atendidas pelo PEA; b) compreender as expectativas das famílias com relação à escola e à escolaridade dos filhos; c) Verificar a disponibilidade por parte das famílias para frequentar a escola fora das reuniões de entrega de boletins; d) analisar como as famílias percebem o território onde vivem e suas possíveis interferências na escolarização de seus filhos.

Nossas observações pretendiam ser uma estratégia que colaborasse com o entendimento sobre como os responsáveis são acolhidos pela escola e como se dão as relações a partir daí. Por exemplo, se aguardam seus filhos dentro ou fora do pátio escolar ou se alguém da escola conversa com eles, se as crianças pequenas são liberadas mediante a presença de um familiar ou não, se existem espaços que os responsáveis podem frequentar no interior da escola.

Também foram registrados alguns conselhos de classe e reuniões de responsáveis pelos alunos com os profissionais da escola como forma de avaliar a relação direta entre a escola e as famílias. 
Nesse sentido, nossas principais questões de pesquisa foram as seguintes:

a) $\mathrm{Na}$ percepção dos profissionais da escola e das famílias dos alunos das escolas pesquisadas, houve, no caso da escola participante do PEA, maior aproximação entre escola e famílias da Maré?

b) Há diferenças significativas entre a escola participante do PEA/BE e a escola que não participou em sua relação com a vizinhança?

c) O PEA/BE é um programa que deveria ser replicado para a própria rede de escolas do Rio de Janeiro?

Os roteiros de entrevistas que traduziram essas questões foram construídos levando-se em conta as especificidades de cada agente na relação escola-famíliavizinhança: responsáveis pedagógicos; professores, diretores, funcionários, gestores da SME-RJ e da ONG responsável pelo Bairro Educador.

Assim, as perguntas procuraram trabalhar a partir das seguintes dimensões básicas comuns aos agentes sociais envolvidos no processo de escolarização das crianças da Maré: I. A experiência profissional de cada entrevistado; II. A experiência com sua própria escolarização; III.A visão da função da escola, especialmente a localizada em uma comunidade/favela; IV. A expectativa que cada agente tem sobre a trajetória escolar dos estudantes; V. A qualificação do relacionamento entre escolas, famílias e vizinhança; VI. O grau de conhecimento e engajamento de cada um no Programa Escolas do Amanhã; VII. Como cada agente vê a vizinhança e se acredita que ela incide sobre o trabalho escolar.

Além desse núcleo comum, foram formuladas perguntas específicas para cada grupo de entrevistados, tais como: a dirigida aos responsáveis pelos alunos sobre o comparecimento deles na escola para outras atividades e reuniões que não sejam as de entrega de boletins escolares; ou se eles conhecem os amigos de seus filhos e os outros responsáveis; como eles avaliam o grau de organização dos responsáveis e como é feita a comunicação com a escola; como a família se organiza diante da rotina escolas; o que a família espera para o futuro acadêmico de seus filhos.

Com isso, pretendíamos conhecer melhor o grau de envolvimento dos responsáveis pelos alunos com a escola, com a escolarização das crianças, o grau de controle sobre as atividades extraclasse dos estudantes e, ainda, a forma como as famílias se comunicam com as escolas. 
Já as perguntas destinadas aos professores estão relacionadas à expectativa com relação aos estudantes; se eles enxergam diferenças entre as escolas localizadas nas favelas e as que não estão localizadas nesses territórios; se conhecem o perfil das famílias atendidas pela escola e se, nos conselhos de classe, a questão da relação com as famílias aparece e de que forma aparece. Essas questões permitiram compreender melhor como os professores e professoras enxergam as famílias de seus alunos e como se relacionam com elas a partir das referências construídas coletivamente e individualmente.

Por sua vez, as perguntas direcionadas aos gestores dos projetos tratam dos motivos e dos objetivos que levaram à criação do Programa Escola do Amanhã e do projeto Bairro Escola, sobre a aceitação das propostas do PEA/BE pelas escolas e as dificuldades de implementação do Programa; os limites e as potencialidades de se aplicar o Programa na Maré e se, eles julgam que o Programa conseguiu aproximar as escolas das famílias.

A triangulação das respostas dos diferentes agentes sociais nos permitiu traçar um quadro mais preciso acerca das relações estabelecidas entre escolas, famílias e vizinhança.

No próximo capítulo, apresentaremos três pesquisas que se destacam justamente por desenvolverem instrumentos com os quais nós trabalhamos em nossa pesquisa e que foram importantes referenciais empíricos. Pesquisas que trabalharam com entrevistas, biografias, estudo etnográfico e diário de campo e, assim, nos auxiliaram na construção de nosso objeto de pesquisa e de nossa metodologia de trabalho. 


\section{6 \\ A relação escolas-famílias-vizinhança}

Neste capítulo, desenvolvemos uma breve análise sobre três pesquisas que abordaram casos concretos a respeito das relações entres escolas-famíliasvizinhança. Isso será feito a partir de histórias de pessoas e famílias dos estratos populares, que moram em território marcados pela pobreza e vulnerabilidade.

Incluímos esses estudos em nosso trabalho porque eles nos permitiram discutir os conceitos vistos no capítulo anterior e testá-los a partir de realidades bem parecidas com a que estamos estudando, ou seja, as relações das escolas com as famílias que vivem em territórios populares. Isso nos permite desenvolver também certa "proteção" do perigo de um viés eurocêntrico, já que os conceitos com os quais estamos trabalhando se referem mais a realidades de países europeus ${ }^{26}$.

Assim, a observação dos estudos de caso ora discutidos nos permite trazer para a realidade brasileira os conceitos dos autores com os quais trabalhamos em nossa pesquisa. Daí a importância de termos outras referências, sobretudo empíricas, que nos ajudem a pensar os conceitos que vimos discutindo aqui.Não se trata, no entanto, de se fazer uma "tradução" e aplicar os conceitos diretamente sobre outra realidade. Na verdade, o que queremos é usar as ferramentas conceituais como fonte de inspiração e de ajuda para que possamos compreender os mecanismos de funcionamento de nosso objeto de estudo.

As pesquisas aqui apresentadas têm em comum o fato de defenderem a tese - muito cara à nossa pesquisa - de que o território e a vizinhança importam e influenciam de maneira variada na escolha das escolas, nas relações com os profissionais da escola e no tipo de investimentos que as famílias mais pobres realizam na escolarização de seus filhos. Observaremos, ainda, os objetivos, a metodologia e as principais conclusões que essas pesquisas obtiveram. Isso nos servirá de parâmetro para nossa própria pesquisa. A ideia é apreender como os autores e autoras de pesquisas diversas se apropriaram de seus objetos de pesquisa a partir de diferentes técnicas, mas que têm em comum a pesquisa de natureza qualitativa.

\footnotetext{
${ }^{26}$ A exceção é a referência à realidade chilena com Carolina Flores.
} 


\section{1}

\section{A importância do lugar}

Bourdieu (2008), ao abordar a importância do "lugar" na sociedade contemporânea, chama a atenção para o fato dele traduzir as hierarquias presentes na sociedade e cumprir uma função importante: a de permitir a manutenção das desigualdades sociais através do "efeito de naturalização" (ibidem, p. 160).

Isso significa aceitar como natural ou normal que determinados territórios, lugares para usar a expressão do sociólogo francês, estejam melhor "equipados" e servidos por determinados bens e serviços que oferecem melhores condições de vida para seus habitantes. Segundo Bourdieu é "na relação da distribuição dos agentes e a distribuição dos bens no espaço que se define o valor das diferentes regiões do espaço social reificado" (ibidem, p. 161).

Desse modo, reconhecendo a importância do lugar ou, em nosso caso, do território na conformação das relações sociais e na confirmação das hierarquias sociais, bem como na distribuição de bens e serviços, consideramos a dimensão territorial como fundamental para entendermos as relações que se tecem entre escolas e famílias populares.

Como vimos no capítulo anterior, essa é a linha adotada pelo estudo feito por Carolina Flores (2008), nos bairros pobres de Santiago do Chile. A autora afirma que a concentração da pobreza afeta negativamente os indivíduos, fazendo com que, quanto maior for o nível de segregação, maior será o estigma sobre o território.

Esse fato incide negativamente sobre o trabalho da escola, quando, por exemplo, o que está em jogo são as expectativas dos professores em relação ao sucesso escolar dos seus alunos ou quando se trata dos investimentos públicos nos diferentes bairros da cidade. Desse modo, quanto mais pobres forem os bairros, menos recursos estarão disponíveis, e mais limitado será o leque de escolhas paras seus habitantes.

Entender a relação que os indivíduos constroem e mantém com o seu território e como este incide sobre suas decisões é fundamental. Esse movimento permite a compreensão do lugar e de sua relação com a cultura e a sociabilidade onde se desenvolve o trabalho escolar o que, por sua vez, ajuda a construir um conhecimento melhor da percepção do próprio papel da escola nos territórios mais pobres da cidade. 
Nos itens a seguir, procuraremos observar mais de perto essas relações a partir de pesquisas que investigaram casos concretos tendo como referências as relações entre profissionais da escola, familiares e territórios marcados pela escassez de recursos econômicos e culturais.

\section{2}

\section{Estudo de caso}

Carolina Soares (2009) pesquisou o processo de escolha de escolas feitas por quatro famílias moradoras de duas favelas na zona oeste da cidade do Rio de Janeiro. Segundo a autora, seu objetivo era "investigar as diferentes estratégias" de escolarização utilizadas pelas famílias para entender como as relações sociais estabelecidas na vizinhança e em outros grupos sociais (como local de trabalho, por exemplo) afetam a percepção das famílias acerca da escolha da escola que seus filhos e filhas vão frequentar.

A autora defende a hipótese de que "existem variações tanto objetivas quanto subjetivas" (ibid., p. 07) associadas ao processo de escolha que têm a ver com a forma como as informações circulam e como os recursos se distribuem no território. Isso tem a ver com os conceitos de geografia objetiva e subjetiva das oportunidades e com o conceito de capital social discutido anteriormente. Desse modo, logo de início, Soares faz uma revisão sobre o conceito de capital social e, utilizando as discussões de Coleman e Bourdieu, salienta que este tipo de capital não materializado - só é possível na relação com outras pessoas e grupos que formam redes mais ou menos complexas, mais ou menos homogêneas ou heterogêneas.

Essas redes de relações e reciprocidades podem trazer benefícios no sentido de ampliar oportunidades materiais ou simbólicas de seus participantes, já que é a partir da inserção nas redes que cada um obtém informações e contatos que podem ser traduzidos em ganhos. Contudo, a essa "perspectiva positiva", Soares, se apoiando em Granovetter, faz uma advertência importante: "os setores populares tendem a estabelecer relações fortes, homogêneas e pobres" com o local (ibid., p. 27). Isso acaba funcionando como um limitador, já que "o encerramento da estrutura entre iguais se dá mais pela sobrevivência do que propriamente pela incorporação de novas estruturas de oportunidades amplas”. 
Assim, a posição dos indivíduos nas redes sociais, o seu capital social e o modo como as informações chegam a eles influencia as suas percepções e decisões acerca da escolha do estabelecimento de ensino. Dessa forma, torna-se pertinente também a questão do território, pois ele pode ser um fator facilitador ou limitador na constituição de oportunidades para os moradores. Se pensarmos, por exemplo, no caso das favelas do Rio de Janeiro e o processo histórico de exclusão e confinamento social pelo qual passaram e passam seus moradores, poderemos entender melhor a importância de se considerar esse fator na dinâmica da escolha que os responsáveis pelos alunos devem ou podem fazer no momento de escolher uma escola para seus filhos. Obviamente, o fator território não se limita apenas à escolha das escolas. Na verdade, esse fenômeno afeta todos os aspectos da vida das famílias e dos indivíduos e incide sobre as possibilidades de construção do capital social e cultural.

Nesse sentido, Soares, ao analisar as decisões tomadas pelas quatro famílias em sua pesquisa, apresenta, na prática, como funciona o mecanismo da geografia das oportunidades objetivas e subjetivas e como esse processo tem a ver com a construção de um determinado tipo de capital social.

Ao realizar as entrevistas - todas nas casas das mulheres, enquanto elas realizavam seus afazeres domésticos -, em primeiro lugar, fica claro que as mães - em todas as famílias entrevistadas, eram elas que decidiam a escola e, na maioria das famílias, eram "chefes" da família- investiam na educação escolar de seus filhos e filhas e regulavam o contato com a rua e com os vizinhos. Mesmo nas casas mais pobres, a escola e a escolarização eram valores importantes na vida das famílias, estruturando as relações entre adultos e crianças.

Ao fazer o relato desta experiência, Soares deixa transparecer aspectos importantes dos meandros das entrevistas relativos às características dos entrevistados. Ela discute alguns hábitos familiares e detalha um mundo pouco conhecido pela escola, em termos dos costumes, aspectos físicos das ruas e casas, as ideias e as orientações que guiam os responsáveis familiares no processo de escolha dos estabelecimentos escolares onde seus filhos irão estudar.

É justamente essa complexidade que escapa aos profissionais das escolas. Como não acessam esse mundo extraescolar, o mundo do aluno, os professores e demais agentes escolares acabam por formular julgamentos baseados muitas vezes 
em estereótipos. Esses julgamentos atrapalham as relações entre escolas e famílias e criam verdadeiras armadilhas difíceis de serem desarmadas.

$\mathrm{Na}$ análise das respostas das famílias entrevistadas, a autora deixa claro que quanto mais integrados à vizinhança, mais os responsáveis preferem manter suas crianças nas escolas da favela e que quanto mais apartados da vizinhança, mais os responsáveis preferem a escola fora da favela. O interessante é perceber que essa diferenciação se dá exatamente a partir do tipo de informação a que as famílias têm acesso e do tipo de capital social que construíram.

Soares apresenta o caso de duas mães que matriculam seus filhos em escolas localizadas fora das comunidades/favelas onde moram e duas mães que matriculam seus filhos em escolas localizadas nas comunidades/favelas onde moram. As duas mães que matriculam os filhos fora, por exemplo, se basearam na ideia de que, ao estudar fora, as crianças poderiam se beneficiar de outro ambiente que não apenas o da favela. A escolha se sustenta também na experiência negativa que uma das mães teve com seus outros filhos, que estudaram nas escolas do local. Ambas as mães conversaram com vizinhos e com pessoas de fora do lugar onde moravam para decidirem-se pela escola.

Pelo que nos apresenta Soares, essas duas mães nutrem o desejo de que as escolas sirvam como espaços de socialização e de encontro com a diversidade, ou seja, há esperança de que o contato com "pessoas de fora" possa ajudar a estabelecer novas redes de amizade e que isso, de alguma maneira, beneficie as crianças.

Já as famílias que escolheram as escolas na comunidade/favela, o fizeram por questões muito mais práticas, principalmente relacionadas à proximidade da casa. Essas famílias, de acordo com a descrição feita por Soares, estão inseridas fortemente em redes sociais locais. O acesso dessas famílias a informações sobre outras escolas é limitado e, na avaliação delas, as escolas são todas iguais. Assim, não faz sentido matricular seus filhos em locais mais distantes de casa. Esse fenômeno recoloca a questão de que os grupos populares formam redes socais mais homogêneas, fortes e mais pobres, o que acaba funcionando como um limitador de oportunidades.

Em nosso segundo estudo de caso, apresentado por Cristóvão e Santos (2008),o objetivo principal era entender o porquê de os alunos da rede pública municipal do Rio de Janeiro, notadamente os moradores de favelas, se 
encontrarem em situação de desvantagem, quando comparados aos alunos não moradores de favelas no que concerne "às condições necessárias para a apropriação e retenção do conhecimento escolar" (ibid., p. 288).

A pesquisa de cunho qualitativo foi realizada junto a três escolas públicas próximas a favelas na cidade do Rio de Janeiro. Duas escolas na zona norte da cidade, sendo que uma delas estava localizada na entrada de uma favela, e a outra estava localizada a mais de um quilômetro de distância. A terceira escola, também próxima a uma favela, estava localizada na zona sul da cidade do Rio de Janeiro.

As autoras citam os estudos de Ribeiro e Koslinski (2009), que indicam que a proximidade da escola com a favela afeta o desempenho escolar e que isso poderia ter as seguintes explicações: a) a homogeneidade do público discente; b) a atitude "estigmatizante" do corpo docente sobre os alunos e alunas moradores da favela; c) a dificuldade de se manter um clima escolar propício ao aprendizado, dado que as lógicas culturais escolares e das crianças são bem diferentes.

Assim, por meio de entrevistas e observação nas escolas, as autoras recolheram dados que demonstram como os professores agiam de maneira diferente ao se reportarem às crianças, como as distinguiam e as avaliavam de acordo com a categoria "ser morador de favela ou não". Isso ocorreu indistintamente nas escolas da zona norte e na zona sul. O fato é que quanto mais próximas às favelas mais o corpo discente é estigmatizado.

Esse é um aspecto importante da relação professor-aluno e da relação escola-vizinhança, pois, de acordo com a literatura, as expectativas dos professores sobre seus alunos é um dos fatores mais importantes para o desempenho destes e para a eficácia escolar (FRANCO; BONAMINO, 2005); (SOARES, 2002); (SILVA, 2013).

$\mathrm{Na}$ escola da zona norte, situada mais próxima da favela, por exemplo, o currículo oficial foi esquecido e substituído por uma versão criada pelos professores, que alegaram fazer isso porque as crianças não teriam condições de aprender o currículo oficial. Fato similar aconteceu na escola da zona sul, localizada próxima à favela.

Por outro lado, as autoras observaram que na escola da zona norte, localizada mais distante da favela, a relação dos professores com os alunos era melhor. Os professores enxergavam as crianças como mais "calmas", disciplinadas e interessadas. Obviamente, suas expectativas com relação à 
aprendizagem dessas crianças também eram mais altas, o que poderia incidir sobre a forma e o conteúdo do que ensinam em sala de aula e, consequentemente, sobre os resultados escolares.

Mesmo tendo taxas de desempenho inferiores à média das escolas da cidade, a escola localizada mais distante da favela conseguiu taxas mais elevadas quando comparada às escolas próximas às favelas, tanto da zona norte quanto da zona sul. Isso sugere uma relação entre o efeito-vizinhança, expresso no fato de a instituição estar dentro, próximo ou fora da favela, e o desempenho escolar. Também sugere que as crianças moradoras de territórios marcados pela pobreza são mais estigmatizadas, o que afeta sua relação com a escola e seus agentes de maneira negativa (FLORES, 2008).

Ainda sobre o efeito-vizinhança, as autoras fazem uma observação importante a partir das entrevistas com diretores e professores: nas escolas localizadas próximas às favelas há um clima de insegurança maior por conta da presença do tráfico de drogas e dos constantes confrontos com a polícia. Esse quadro reafirma a importância da discussão sobre o contexto socioeconômico onde estão inseridas as escolas e as relações que estas mantêm com as famílias que as procuram.

No terceiro estudo de caso, de cunho etnográfico, Batista e Silva (2003), acompanharam doze mulheres moradoras de uma favela na cidade de São Paulo, cujos filhos estudavam em escolas públicas. Além das entrevistas com as mães em suas casas - os autores apresentam detalhadamente cada uma dessas casas, incluindo fotos - ,os autores realizaram reuniões com assistentes sociais de uma instituição local e com seus funcionários que atendiam às famílias. Dessa forma, puderam compor um quadro mais complexo e completo das famílias e das mães entrevistadas e delinear o que eles chamaram de "retratos sociológicos" (ibid., p. $17)$.

O objetivo principal da pesquisa foi o de "contribuir para desfazer malentendidos e visões distorcidas que, na maioria das vezes, impedem uma interação enriquecedora entre escola e família das camadas populares" (ibid., p. 13). Como "objetivo específico", tem-se o desejo de apreender como as mães que moram nos territórios vulneráveis se relacionam com a escolarização de seus filhos e filhas e que estratégias usam para realizar essa tarefa. 
É interessante observar, também, que os autores "endereçam”, logo na introdução, a pesquisa aos "educadores" e às escolas como se fosse um chamado para que eles olhem para essas famílias e reconheçam as estratégias e os muitos esforços feitos cotidianamente pelas mães ao realizarem o trabalho de cuidar da escolarização de suas crianças. Aliás, essa é uma questão que consideramos das mais importantes porque, em muitos momentos, a escola simplesmente não consegue enxergar as famílias.

Segundo os autores, na raiz do desejo de compreender os processos acima estão três grandes discursos: o primeiro é dos profissionais da escola que afirmam um descompromisso das famílias mais pobres com a escola e com a escolarização. Segundo esse discurso, os responsáveis pelos alunos são "omissos" diante da escolarização de suas crianças. Ressaltamos que o segundo discurso complementa o primeiro - já que admite como verdade a afirmação da omissão parental - e propõe a mobilização e a educação das famílias pobres para elas passarem a valorizar a escola e a escolarização de suas crianças; o terceiro discurso se contrapõe aos anteriores na medida em que afirma que a omissão parental é um mito e que as famílias não precisam ser "educadas" para entender a importância da educação.

O pressuposto adotado pelos autores tem com base conceitual o terceiro discurso, ou seja, considera que a ideia de omissão parental é um mito (ibid., p. 14). Segundo Batista e Silva, o afastamento dos responsáveis pelos alunos da escola tem a ver com duas questões básicas. De um lado, o fato de a escola esperar um comportamento que não é próprio das famílias populares. Isto é, a escola espera um comportamento mais afeito aos grupos sociais cuja relação com o mundo letrado seja mais natural por conta de um determinado tipo de capital cultual. Por outro lado, a relação com a escola tende a ser vivida pelos responsáveis das famílias populares como "externa” ou artificial ao universo familiar.

Assim, citando Bernard Charlot, os autores afirmam que, muitas vezes, a relação das famílias populares com a escola e com a escolarização não é de omissão parental, mas carregada de sofrimento, constrangimento e sentimento de impotência (ibid., p. 15).

Fica claro, dessa maneira, que a escola ainda é um mundo que não pertence a essas pessoas, é um mundo que, paradoxalmente, está perto, merece todos os 
esforços e investimentos das famílias mais pobres, mas permanece fechado para elas.

Durante as entrevistas feitas com as mães de alunos, os autores puderam observar como elas definiam suas estratégias de acompanhamento escolar de seus filhos e filhas e como escolhiam as escolas, analisando suas características em conjunto com as especificidades do território. Todas as doze mulheres, dentro de suas condições de vida e possibilidades cognitivas, econômicas e culturais, alimentavam expectativas altas sobre a escolarização de seus filhos.

Mesmo no caso emblemático de uma delas, justamente a mais pobre e mais afastada da cultura escolar, havia a preocupação com a escolarização e com a proteção das crianças com relação à "rua". Nesta entrevista constatou-se o quanto a precariedade da vida material e a distância do mundo escolar, a partir da história de sua própria escolarização, aliadas às dificuldades sociais que se colocam no território - como, por exemplo, o comércio e o tráfico de drogas - eram fatores que dificultam o acompanhamento melhor dos filhos e filhas na escola.

De modo geral, os estudos apresentados apontam que as famílias, principalmente as mães, reorganizavam a vida familiar em função da escola e faziam uma série de investimentos em função dessa aposta. Investimentos que, em muitos casos, exauriam os já limitados recursos familiares e mobilizavam conhecidos e vizinhos.

Assim, contratar "explicadoras", contratar transporte escolar, reorganizar horários da família, organizar os estudos em casa e contar com a ajuda de vizinhos para "olhar" as crianças faziam parte dos muitos ajustes em prol da escolarização. As famílias mobilizavam todo o pouco capital que possuíam para investir na escolarização de suas crianças.

Desse modo, uma das conclusões mais importantes da pesquisa, sem dúvida, é a de que, como mulheres pobres e de poucos recursos materiais, essas mães viam na escola e na escolarização de seus filhos e filhas uma oportunidade para um futuro melhor e sem as muitas dificuldades que elas próprias enfrentavam no cotidiano. O desejo mais comum era o de que as crianças pudessem superá-las através da educação escolar.

Por fim, o que os estudos de caso analisados aqui nos permitem dizer é que conhecer melhor as famílias, suas dificuldades, limites de ação e estratégias de escolarização de filhos e filhas, aliado à compreensão do contexto local é 
fundamental para discutir a complexa relação que as famílias estabelecem com as escolas. Isso nos permite ainda abandonar os discursos, infelizmente tão em voga no senso comum escolar, de que as famílias pobres não se interessam pela escola e pela escolarização de suas crianças.

Permite-nos também fazer a crítica ao discurso que culpa as famílias pelo insucesso escolar e, assim, nos permite enxergá-las de outra maneira, reconhecendo seus esforços e sua crença na instituição escolar apesar de todos os mal-entendidos e desencontros com ela. 


\section{O território: a Favela da Maré}

\section{1}

\section{A favela na cidade}

O surgimento das favelas na cidade do Rio de Janeiro completou 120 anos, desde que os primeiros soldados vindos da "Guerra de Canudos" 27 , sem ter onde morar, subiram as encostas do Morro hoje conhecido como o Morro da Providência. Lá eles estabeleceram um padrão de moradia - barracos feitos de madeira e latão - que rapidamente se espalharia para outros morros e lugares da cidade. E, ao darem ao seu morro o nome de "Morro da Favela", em homenagem ao morro em que ficavam acampados no sertão da Bahia, sem saber, estavam nomeando o lugar dos pobres na cidade.

Hoje, $20 \%$ dos moradores da cidade do Rio de Janeiro vivem em favelas. Mas, apesar da presença histórica, geográfica e cultural desses territórios ter se tornado uma das marcas da cidade, eles ainda assim são pouco conhecidos e pouco frequentados por não moradores. Isso porque são territórios estigmatizados como pobres e violentos.

Contribui para essa situação uma série de fatores, a começar pela atuação do Estado que mantém uma relação de precariedade na oferta de serviços básicos, tais como a assistência em saúde, educação, transporte e segurança pública, para ficarmos apenas em algumas das áreas mais importantes.

Obviamente, essa ausência ou insuficiência de investimentos trouxe problemas sérios. A atitude de negligência por parte do poder público acarretou, por exemplo, a expansão e o domínio de grupos criminosos sobre muitas favelas cariocas. Por sua vez, esse fato ajudou a construir um imaginário social que condena os pobres e os identifica como as "classes perigosas",definindo-os como sujeitos potencialmente criminosos.

$\mathrm{Na}$ verdade, muito antes do domínio dos grupos criminosos se expandir, ainda nos anos de 1980, sobre esses territórios populares, as favelas já eram vistas como o avesso da cidade e mesmo como um perigo.

\footnotetext{
${ }^{27}$ Comumente se atribui aos soldados do exército brasileiro que combateram os sertanejos de Antonio Conselheiro, na Bahia, a fundação do que seria a primeira favela carioca: o "Morro da Favela". Como não receberam apoio do governo da república, os soldados, sem ter para onde ir, se instalaram nas proximidades do ministério, ou seja, no morro mais próximo.
} 
O engenheiro e membro do Rotary Club do Brasil, Mattos Pimenta, um dos pioneiros no estudo sobre as favelas cariocas, afirmava em 1926, que era

[...] mister que se ponha um paradeiro immediato, se levante uma barreira prophilactica contra a infestação avassaladora das lindas montanhas do Rio de Janeiro pelo flagello das 'favellas' - lepra da esthetica, que surge ali no morro, entre a estrada de ferro Central do Brasil e Avenida do Cães do Porto e foi se derramando por toda a parte, enchendo de sujeira e de miséria preferentemente os bairros mais novos e onde a natureza foi mais prógdiga de beleza (VALLADARES, 2000).

Assim, a cidade, ao olhar para esses espaços que cresciam vertiginosamente a cada ano, via-os como uma ameaça, um "flagelo". Desse modo, engenheiros, arquitetos, urbanistas, médicos e jornalistas deixaram inúmeros registros sobre como viam as favelas. Nesse processo eles ajudaram a construir um imaginário social que persiste - incorporando novos elementos - ainda hoje.

Um ano depois do estudo de Mattos Pimenta, ou seja, em 1927, o então prefeito Prado Junior convidou o sociólogo e urbanista francês Alfred Agache para criar um projeto de desenvolvimento para o Centro do Rio de Janeiro.

Ao final de seus estudos, o urbanista, apesar de reconhecer que as favelas eram produtos da "indiferença manifestada até hoje pelos poderes públicos, relativamente às habitações da população pobre"(VALLADARES, 2000), apresentava uma visão muito próxima da defendida por Mattos Pimenta.

Dessa forma, ao ganhar seu primeiro projeto urbanístico, o famoso "plano Agache", a cidade escolhia a favela como "problema a ser resolvido". Este plano, que se inspirava em Paris e em seus famosos bulevares, dizia que a favela:

Suja a vizinhança das praias e os bairros mais graciosamente dotados pela natureza, despe o morro de seu enfeite verdejante e corro e até as margens da mata na encosta das serras (VALLADARES, 2000).

O Plano Agache não saiu do papel, tragado pela precipitação da "Revolução de 30", comandada por Getúlio Vargas, que se colocaria como o "pai dos pobres" e inauguraria um novo tipo de relacionamento com os mais pobres. Porém, isso não impede que, em 1937, quando surge o primeiro código de obras na cidade, a questão das favelas volte com força no cenário político. Nesse documento há, por exemplo, um capítulo exclusivamente dedicado às favelas.

$\mathrm{Na}$ verdade, o código de obras retoma a proposta que o engenheiro francês já propusera em seu relatório final, ou seja, a remoção das populações faveladas e a criação de "alojamentos salubres" para abrigá-las.A novidade, no entanto, reside 
no fato de que se fala em remoção, o Código também fala em "contenção do crescimento das favelas já existentes", ou seja, pela primeira vez se coloca a possibilidade do reconhecimento das favelas já existentes como territórios da cidade. O quese tem, então, é a possibilidade de uma "aceitação" ou tolerância da existência das favelas e, ao mesmo tempo, o reconhecimento de que o problema da habitação dos pobres não é um problema individual, mas da sociedade e assunto do Estado.

Outro capítulo importante na história das favelas em sua relação com o restante da cidade foi a criação da Fundação Leão XIII, em 1946. Nascida de uma "parceria" entre a prefeitura do Rio de Janeiro e a arquidiocese da cidade, a nova instituição deveria prestar assistência moral e educacional aos mais pobres moradores das favelas cariocas.

Embora, a ideia da remoção das favelas não tenha sido esquecida - pelo contrário, desde 1940, o relatório do médico Vitor Tavares propunha que se controlasse a entrada na cidade de "indivíduos de baixa condição social" - a fundação da Leão XIII mostra que as favelas ganhavam cada vez mais importância a ponto do Estado e a Igreja estarem unidos para dar algum tipo de assistência às pessoas que habitam nesses territórios. Essa união também teve um caráter político, pois procurou fazer frente à expansão da influência do partido comunista que se aproximava de lideranças populares.

Em 1948, foi feito o primeiro censo de favelas do "Distrito Federal" o qual localiza e dimensiona as favelas da capital da República. Dois anos mais tarde, é realizado o censo do IBGE que traz dados sobre as favelas e, pela primeira vez, procura definir conceitualmente o que é a favela ${ }^{28}$.

O que o Censo revelou foi que há aumento do número de favelas em todas as áreas da cidade, especialmente na zona norte: Méier com 17 favelas e no subúrbio da Penha com 11 favelas. Na Zona Sul, Botafogo é o bairro onde ocorre o maior crescimento chegando ao total de 14 favelas. O crescimento das favelas se acentua nos anos de 1950, com a chegada de imigrantes de regiões como o norte e nordeste do Brasil, atraídos pelas promessas de vida melhor no Sudeste que então se industrializava.

\footnotetext{
${ }^{28}$ Conjunto constituído de, no mínimo, 51 unidades habitacionais (barracos casas), ocupando ou tendo ocupado até período recente, terreno de propriedade alheia (pública ou particular) dispostas, em geral, de forma desordenada e densa, bem como carentes, em sua maioria, de serviços públicos essenciais.
} 
Porém, é nos anos 1960 que há uma "explosão demográfica nas favelas". Algumas chegam a crescer $500 \%$, como foi o caso do morro da Coroa (Santa Teresa) e da Rocinha, que cresceu 200\% (PEREIRA DA SILVA, 2005). Não foi mera coincidência que justamente nesse momento tivesse início o período de maior remoção de favelas na cidade. Foi o momento, também, da criação dos primeiros Parques Proletários, para onde deveriam ser removidos os favelados. A ideia dos Parques era de que as populações faveladas deveriam ser "civilizadas" e educadas moralmente para que pudessem ser integradas à sociedade.

O governador Carlos Lacerda e seus sucessores Negrão de Lima e Chagas Freitas (VALLADARES, 2000) são os repensáveis pela remoção de, pelo menos, oitenta favelas e de mais de 139 mil pessoas que moravam nelas. É importante destacar que as remoções desse período se dão em favelas localizadas em áreas centrais da cidade ou da já valorizada zona sul, permitindo inferir que a remoção andava de braços dados com o velho projeto de uma cidade que tivesse lugares distintos para ricos e pobres, o que era perseguido desde o Plano Agache.

O fato, porém, é que, mesmo com as remoções, - e com a resistência das populações das favelas que passaram a se organizar e constituir, por exemplo, suas associações de moradores - nos anos de 1970 e 1980, as favelas se firmam definitivamente como territórios da cidade. Era impossível ignorá-las ou tratá-las como fenômeno passageiro. Em 1992, o novo plano diretor da cidade do Rio de Janeiro finalmente incorpora as favelas. Só a partir desse momento elas passam a fazer parte do mapa oficial da cidade. Assim, a favela deixa de ser vista como algo à parte e passa a integrar o território do Rio Janeiro oficialmente.

Ainda assim, somente em 2016, o serviço de localização de mapas oferecido pela Google começou a incluir as favelas no mapa da cidade. Até então, elas apareciam como grandes manchas de cor cinza quando se buscava algum endereço na cidade do Rio de Janeiro.

O fato é que, hoje, as favelas, a despeito de seu reconhecimento como territórios da cidade, permanecem sendo vistas como um "problema" a ser resolvido. As remoções ainda continuam a ameaçá-las, como foi o caso das recentes remoções feitas, sobretudo na zona oeste, para a realização dos Jogos Olímpicos de 2016. A vida nesses territórios, como dissemos no início, ainda é marcada pela precariedade dos serviços do Estado e pela ausência de investimentos do mercado. 
Contudo, há uma série de movimentos comunitários, movimentos culturais e uma economia interna que não podem ser desconsiderados. Por exemplo, segundo estimativa do Instituto Data Favela, a renda gerada nas favelas ultrapassa os R\$ 12,3 bilhões por ano. Portanto, se existem questões urgentes e desafiadoras como a pobreza e a presença dos grupos criminosos armados, há também uma série de inciativas locais que abrem possibilidades interessantes nas favelas cariocas. É justamente nesse cenário que a escola pública atua e isso só aumenta a sua responsabilidade na educação das crianças desses territórios. Na favela, as escolas precisam ser muito mais do que instituições de ensino somente.

\section{2}

\section{A Favela da Maré}

O conjunto de favelas da Maré é o maior da cidade do Rio de Janeiro, com uma população de mais de 136 mil moradores, que habitam pouco mais de 43 mil domicílios dispostos em uma área de quatro mil quilômetros quadrados. Isso constitui um adensamento grande e um contingente populacional significativo, o que dá a esse conjunto de favelas a impressionante marca de ser maior do que 93\% das cidades do Brasil.

O território da Maré compõe os arrabaldes da Leopoldina, zona norte da cidade, e seus primeiros moradores chegaram ainda nos anos 40, do século passado, vindos do interior do Rio de Janeiro, de Minas Gerais, do Nordeste e do Centro do Rio de Janeiro, onde os altos aluguéis expulsaram os mais pobres. Atualmente, a Maré é constituída por dezesseis comunidades/favelas que variam de tamanho, densidade populacional, história e poder aquisitivo de seus moradores.

A região da Maré, hoje central na cidade - localizada entre as Linhas Vermelha e Amarela e a Avenida Brasil -, era formada por mangues e por uma única área seca, um morro, o Morro do Timbau. Entre as décadas de 1940 e 1960, as favelas são formadas, erguidas exclusivamente por obra dos moradores, assim o Morro do Timbau (1940), a Baixa do Sapateiro (1947), o Conjunto Marcílio Dias (1948), o Parque Maré (1953), o Parque Rubens Vaz (1954), o Parque União (1961) e a Praia de Ramos (1962) foram construídas pelas mãos daqueles que afirmam seu lugar na cidade sem nenhum tipo de apoio a não ser a solidariedade dos vizinhos. 
Entretanto, entre da década de 1960 até o ano 2000, o crescimento da Maré também está ligado à intervenção do poder público, que construiu um centro de habitação provisória -receberiam pessoas removidas de outras favelas que depois seriam transferidas para conjuntos habitacionais na zona norte da cidade -, Nova Holanda (1962), e depois os seguintes conjuntos habitacionais: Conjunto Esperança (1982), Vila do João (1982), Vila do Pinheiro (1983), Conjunto Pinheiro (1989), Conjunto Bento Ribeiro Dantas (1989), Nova Maré (1996) e Salsa e Merengue (2000).

A Tabela 1, a seguir, ilustra de maneira mais detalhada a composição das favelas que formavam a Maré quando da realização o Censo 2010, pelo IBGE. Esses números muito provavelmente sofreram alterações desde então por conta do intenso crescimento da Maré desde então.

Tabela1 - Composição de populacional por comunidade/favela

\begin{tabular}{|l|r|r|}
\hline Comunidade/favela & Habitantes & Domicílios \\
\hline Morro do Timbau & 6.359 & 2.109 \\
\hline Baixa do Sapateiro & 7.757 & 2.590 \\
\hline Parque Maré & 12.322 & 3.999 \\
\hline Parque União & 19.662 & 6.621 \\
\hline Roquete Pinto & 7.488 & 2.382 \\
\hline Praia de Ramos & 3.073 & 932 \\
\hline Nova Holanda & 15.450 & 4.729 \\
\hline Vila dos Pinheiros & 15.492 & 4.974 \\
\hline Vila do João & 13.301 & 4.545 \\
\hline Salsa e Merengue & 7.258 & 2.130 \\
\hline Marcílio Dias & 6.759 & 1.768 \\
\hline Conjunto Esperança & 5.530 & 1.870 \\
\hline Rubens Vaz & 5.154 & 1.710 \\
\hline Conjunto Bento Ribeiro Dantas & 3.580 & 953 \\
\hline Nova Maré & 3.174 & 850 \\
\hline Conjunto Pinheiros & 4.115 & 1337 \\
\hline Total & 136.474 & 43.499 \\
\hline
\end{tabular}

Fonte: IBGE, Censo demográfico (2010) 
Temos, assim, duas fases de crescimento e expansão distintas: uma realizada pelos moradores a partir de seus recursos e sem nenhum apoio do Estado ou do mercado- momento marcado pela grande resistência desses moradores contra as tentativas de remoção realizadas pelo poder público - e outra, realizada pelo próprio poder público, sobretudo nas décadas de 1960 até 1990 do século passado.

O processo de consolidação da Maré ganhou contornos definitivos quando foi criada a $30^{\text {a }}$ Região Administrativa, em 1986, especialmente para atender à área da Maré e, mais tarde, quando uma lei municipal de $1994^{29}$, transformou a região oficialmente em bairro. Ainda na década de 1980, e ao longo dos anos 1990, a Maré viveu a irrupção dos grupos criminosos armados que passaram a dominar partes de seu território e a estabelecer o controle quase absoluto sobre eles. Tal fato impactou profundamente a vida dos moradores.

Os índices de violência aumentaram drasticamente e a resposta dada pelo Estado a essa situação oscilou entre o descaso e a repressão policial. No final dos anos 2000, o problema se agrava com a constituição das chamadas milícias ${ }^{30}$. Esse cenário prejudicou sobremaneira a Maré, pois, gradualmente, afastou empresas, investimentos econômicos e a própria ação dos órgãos públicos, que passam a oferecer cada vez menos seus serviços e precarizam aqueles que já eram oferecidos. Como exemplo, tem-se o fechamento de dois postos policiais, nas favelas Nova Holanda e Vila do João.

Os dados dos censos do IBGE de 2000 e 2010 demonstram que a Maré cresceu $14 \%$ enquanto a cidade, em seu conjunto, cresceu 7,9\%. Isso torna a Maré o nono bairro mais populoso - de um total de 160 - do Rio de Janeiro, o que pode ser constatado pelo fenômeno da "verticalização" das moradias dado o alto grau de adensamento populacional.

Em sua maioria, a população da Maré é composta por pretos e pardos (IBGE, 2010) que trabalham, sobretudo, no setor de serviços, comércio e na construção civil. Em termos de rendimentos, na média, pouco mais de $60 \%$ dos domicílios da Maré possui renda per capita entre ume dois salários mínimos, e apenas $28,31 \%$, na média, têm rendimento per capita superior a dois salários

\footnotetext{
${ }^{29}$ Lei municipal $\mathrm{n}^{0} 2.119$ de 19 de janeiro de 1994.

${ }^{30}$ Grupos paramilitares formados por polícias da ativa e da reserva e por bombeiros, que controlam territórios antes pertencentes aos grupos que traficavam drogas.
} 
mínimos. Para o conjunto da cidade, respectivamente, esses indicadores de renda são: 42,1\% e 34,1\% (IBGE, 2010). Isso demonstra que há forte desigualdade no que concerne ao rendimento dos moradores da Maré quando comparados à média da cidade.

Na tabela a seguir, é possível observar, por comunidade/favela da Maré as diferenças de rendimentos, bem como as faixas de rendimentos.

Tabela 2 - Composição de renda segundo as comunidades/favelas

\begin{tabular}{|l|c|c|c|c|}
\hline \multicolumn{1}{|c|}{ Comunidade } & 0 a 1 SM & 1 a 2 SM & 3 a 6 SM & 7 ou mais SM \\
\hline Vila do João & 5,72 & 63,6 & 28,20 & 2,45 \\
\hline Salsa e Merengue & 6,65 & 64,6 & 27,95 & 0,76 \\
\hline Conjunto Pinheiros & 4,09 & 57,5 & 34,11 & 4,29 \\
\hline Vila Pinheiros & 8,32 & 63,7 & 25,43 & 2,51 \\
\hline Conjunto Esperança & 5,33 & 55,4 & 35,31 & 3,94 \\
\hline Bento Ribeiro Dantas & 5,59 & 63,3 & 28,32 & 2,80 \\
\hline Nova Holanda & 3,71 & 69,3 & 24,91 & 2,12 \\
\hline Nova Maré & 10,21 & 65,7 & 21,52 & 2,62 \\
\hline Marcílio Dias/Mandacaru & 9,03 & 62,1 & 25,96 & 2,93 \\
\hline Ramos/Roquete Pinto & 5,97 & 60,4 & 31,34 & 2,24 \\
\hline Parque União & 3,24 & 56,9 & 35,31 & 4,58 \\
\hline Rubens Vaz & 4,30 & 64,6 & 29,11 & 2,03 \\
\hline Parque Maré & 5,60 & 68,5 & 23,44 & 2,49 \\
\hline Morro do Timbau & 1,58 & 60,9 & 31,75 & 5,79 \\
\hline Baixa do Sapateiro & 2,80 & 65,3 & 28,45 & 3,45 \\
\hline Média da Maré & $\mathbf{5 , 6 0}$ & $\mathbf{6 3 , 1}$ & $\mathbf{2 8 , 3 1}$ & $\mathbf{3 , 0 3}$ \\
\hline
\end{tabular}

Fonte: Censo de favelas da Maré: Redes da Maré.

Sem dúvida, o fator renda é um limitador para o desenvolvimento desse conjunto de favelas e, consequentemente, de seus moradores, pois o acesso a bens e equipamentos oferecidos pelo mercado ficam distantes de suas reais possibilidades econômicas.

Por outro lado, serviços públicos também são oferecidos de maneira precária, como é o caso do atendimento à saúde. A Maré possui uma Unidade de Pronto Atendimento (UPA) e nove postos de saúde menores, mas que têm seus serviços oferecidos de maneira insatisfatória e incompleta, segundo os moradores locais. Já no que se refere à cultura, a Maré possui duas Lonas Culturais equipamentos da prefeitura -, sendo que uma está desativada. Um museu administrado por uma organização não governamental local e um Centro de Artes administrado por outra ONG. 
Assim, se considerarmos que o acesso à cultura e lazer, em grande medida, são oferecidos por agentes privados - os equipamentos públicos praticamente não existem na Maré -, sobretudo, pelas organizações comunitárias locais, temos um quadro de supressão ou, pelo menos, de limite do direito à cultura.

Desse modo, em consequência da renda abaixo da média da cidade, do limitado poder de consumo dos moradores locais, da falta de políticas públicas com maior alcance e mais qualidade nas áreas de segurança, cultura e renda, criase um quadro de vulnerabilidade perigoso. Por conta dessa situação, as oportunidades de desenvolvimento individual e coletivo são bastante limitadas para os moradores da Maré.

Assim, quando recuperamos o conceito de geografia das oportunidades objetivas constatamos o quanto as opções ou oportunidades para os moradores da Maré são escassas. E que, apesar do trabalho das instituições locais, o desenvolvimento de um capital cultural e social mais amplo fica prejudicado. Esse estado de coisas conforma hábitos e organiza as relações internas que incidem, sem dúvida, sobre as relações entre escolas-família-vizinhança. 


\section{8 \\ O que dizem os dados de desempenho da Maré}

8.1

Dados educacionais da Maré

No que se refere à educação escolar, a região da Maré possui dezesseis escolas públicas, sendo quatorze escolas da rede municipal e duas da rede estadual (duas escolas de ensino médio também funcionam no turno da noite, sendo uma em prédio próprio e outra em prédio compartilhado com o município). O conjunto de escolas municipais e estaduais atende a 16.799 estudantes e se estende por toda a região ${ }^{31}$.

De acordo com o Censo de 2010, a taxa de analfabetismo da Maré pode ser considerada alta se comparada à cidade do Rio de Janeiro. Enquanto a taxa da Maré fica em torno de $8 \%$, a do município fica em torno de 3\%, ou seja, a Maré tem quase três vezes mais analfabetos que a média da cidade. Em razão disso, dos 160 bairros que compõem a cidade do Rio de Janeiro, a Maré ocupa a $157^{\mathrm{a}}$ posição em termos de desenvolvimento humano.

Quando observamos os dados correspondentes ao número de universitários ou de adultos que cursaram o ensino superior os números são opostos. Assim, enquanto a Maré tem uma taxa de universitários próxima a 1,5\%, na cidade, esse número salta para algo perto de $25 \%$. Ou seja, é muito mais fácil uma criança na Maré ter um parente analfabeto do que alguém com curso superior. Como discutido em outro ponto, esse é um quadro preocupante, pois limita sobremaneira as oportunidades de crianças que moram nesse território. A Tabela 3 apresenta as escolas da Maré segundo o número de alunos atendidos, o Índice de Desenvolvimento da Educação Básica (IDEB) ${ }^{32}-$, rede de ensino, taxa de fluxo e localização. As escolas assinaladas em cinza participam do PEA/BE.Para

\footnotetext{
${ }^{31}$ Em agosto de 2016, foram inauguradas mais dez escolas públicas na Maré. Segundo a SME-RJ a ideia é transformar todas as escolas da Maré, a partir do Projeto Escolas do Amanhã, em turno integral. Os alunos seriam redistribuídos e por isso, a necessidade da construção de mais unidades escolares. Esse processo, pelo que pudemos apurar ainda não foi concluído.

${ }^{32} \mathrm{O}$ Índice de Desenvolvimento da Educação Básica (IDEB) é o indicador nacional que reflete a situação da unidade escolar a partir do resultado de dois componentes: o fluxo versus pelo aprendizado dos/as estudantes. $\mathrm{O}$ fluxo corresponde às taxas de reprovação e abandono fornecidas pelo Censo Escolar. A aprendizagem é o resultado da avaliação externa (SAEB, Prova Brasil) com o foco nas disciplinas de Língua Portuguesa e Matemática.
} 
preservar a identidade das escolas e dos entrevistados, optamos por nomeá-las por cores.

Tabela 3 - Dados das escolas da Maré: IDEB 2015

\begin{tabular}{|c|c|c|c|c|c|}
\hline Escolas Municipais & $\begin{array}{l}\text { Número de } \\
\text { alunos }\end{array}$ & IDEB: 5 ano & $\begin{array}{c}\text { IDEB 2015: } 9 \\
\text { ano }\end{array}$ & Taxa de fluxo & Modalidade de ensino/Rede municipal \\
\hline Verde & 675 & 4,5 & não se aplica & 0,79 & Educação Infantil Ensino Fundamental I \\
\hline Bege & 1.039 & _ & - & - & Educação Infantil / Ensino Fundamental I \\
\hline Azul & 525 & 6,1 & não se aplica & 0,93 & Ensino Fundamental I \\
\hline Amarelo & 966 & 4,9 & não se aplica & 0,91 & Ensino Fundamental II \\
\hline Cinza & 539 & não se aplica & _- & _- & Ensino Fundamental II \\
\hline Preto & 853 & 5 & não se aplica & 0,87 & Educação Infantil / Ensino Fundamental I \\
\hline Vermelho escuro & 339 & 6 & não se aplica & 0,99 & Ensino Fundamental I \\
\hline Marrom & 1.633 & sem dados & sem dados & _- & Ensino Fundamental I e II \\
\hline Laranja & 1.166 & 5,4 & não se aplica & 0,96 & Ensino Fundamental I \\
\hline Rosa & 1.769 & 4,8 & _ & 0,84 & Ensino Fundamental I e II \\
\hline Roxo & 603 & 5,1 & não se aplica & 0,89 & Educação Infantil / Ensino Fundamental I \\
\hline Branco & 571 & 5,4 & não se aplica & 0,9 & Educação fundamental \\
\hline Azul Escuro & 735 & não se aplica & 4,5 & 0,79 & Ensino Fundamental II \\
\hline Vermelho & 284 & 5 & não se aplica & 0,94 & Ensino Fundamental I \\
\hline Verde Claro & 917 & 5 & 3,3 & $0,85 / 0,64$ & Ensino Fundamental I e II \\
\hline Violeta & 1.336 & _- & 3,1 & 0,61 & Ensino Fundamental I e II \\
\hline Total & 16.799 & IDEB/RJ 5,6 & IDEB/RJ 4,3 & $\mathbf{0 , 9 1 / 0 , 8 4}$ & Ensino Fundamental I e II \\
\hline
\end{tabular}

Elaboração própria a partir da página www.qedu.org.br.

OIDEB da cidade do Rio de Janeiro foi 5,6 para os anos iniciais do ensino fundamental em 2015. Apenas duas escolas da Maré - Escola Vermelho Escuro e Escola Azul - ultrapassaram esse índice. As demais escolas ficaram entre 4,5 e 5,4 , revelando as dificuldades das escolas da Maré no segmento inicial da carreira escolar dos estudantes.

Esse quadro se mantém quando observamos o segundo segmento do ensino fundamental (ensino fundamental II). Das três escolas com dados para esse segmento, apenas uma conseguiu ficar acima do índice da cidade do Rio de Janeiro $(4,3)$. As demais escolas ficaram abaixo dessa média em um ponto. Notase, ainda, que tais escolas apresentam índices de reprovação e/ou abandono altos, o que tem impacto no fluxo escolar. 
Embora nossa questão de pesquisa não esteja relacionada à medida de desempenho escolar dos estudantes da Maré, julgamos pertinente observar um pouco mais de perto o quadro acima. Com ele, podemos situar as escolas da região no contexto mais amplo da rede municipal de ensino e tecer algumas observações acerca das implicações para as famílias da Maré do melhor ou pior desempenho das escolas onde seus filhos estão matriculados. Isso é importante porque as famílias também guiam suas escolhas e estabelecem relações de determinado tipo com as escolas a partir das informações e impressões sobre o desempenho escolar.

\section{2}

\section{Desempenho das escolas da Maré}

O gráfico a seguir apresenta a série histórica da evolução do IDEB das escolas da Maré e da cidade do Rio de Janeiro entre os anos de 2005-2015. Ele possibilita uma dupla comparação: por um lado, permite comparar as escolas participantes do PEA/BE com elas mesmas no tempo; por outro lado, permite a comparação com as escolas que não participam do Programa.

Embora nossa preocupação maior não seja com os resultados escolares, consideramos pertinente observar o histórico do IDEB das escolas da Maré, pois uma das promessas do PEA/BE é justamente aportar mais recursos para a melhoria de desempenhos das escolas que dele participam. A pergunta que nos colocamos aqui é: há diferenças significativas entre as escolas do PEA/BE e as que não estão no Programa? 


\section{Gráfico 1 - IDEB: Escolas da Maré 2007-2015 - anos iniciais (dados INEP)}

IDEB

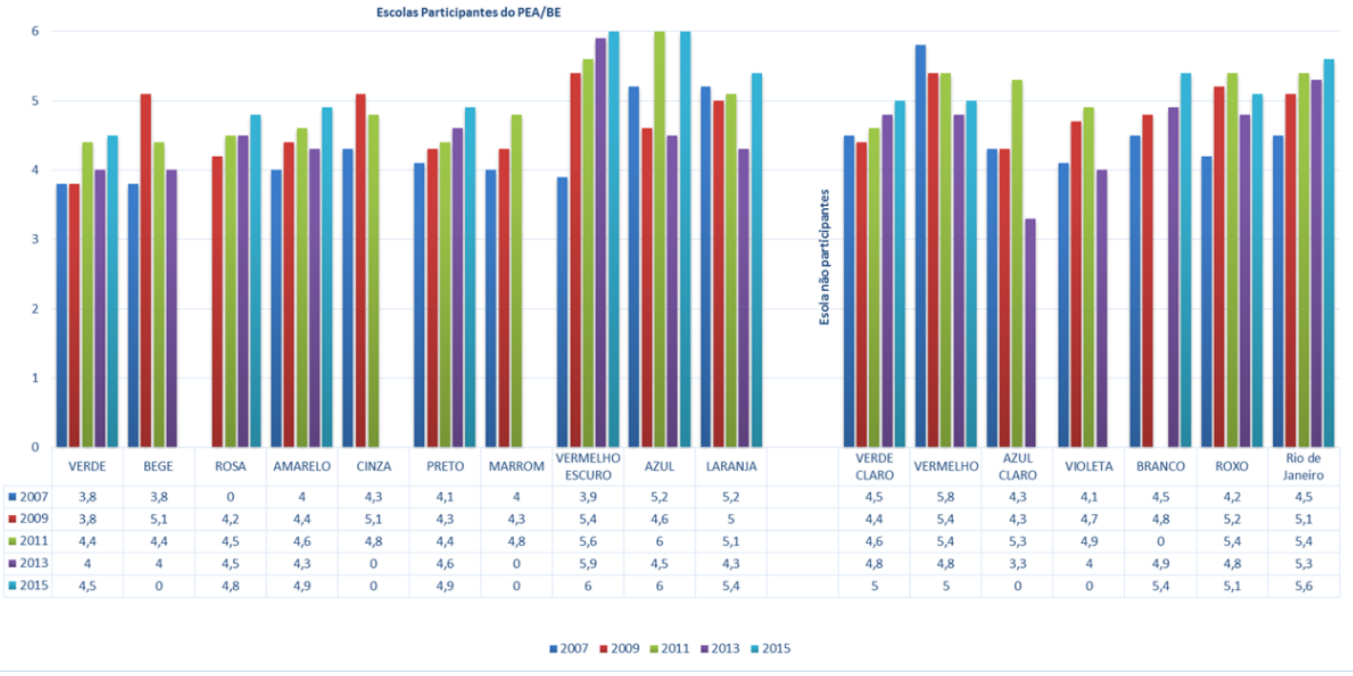

O Gráfico 1 nos mostra que, de modo geral, houve evolução do IDEB ao longo dos anos em todas as escolas da Maré. Podemos ver que tanto as escolas participantes do PEA/BE quanto as não participantes aumentaram seu IDEB ao longo dos anos. Na verdade, esse movimento acompanhou a evolução do IDEB médio das escolas da cidade do Rio de Janeiro. Assim, constatamos duas questões: primeiro que as escolas do PEA/BE evoluíram mais ou menos da mesma forma do que as que não participam do Programa e, depois, que nos parece que a evolução das escolas da Maré seguiu a tendência da rede municipal.

Quando olhamos mais especificamente para o ano de 2015, constamos que apenas duas escolas da Maré superaram a média da cidade e que, assim, apesar de acompanharem a tendência de crescimento geral, as escolas da Maré, em sua maioria, se mantiveram abaixo da média da cidade. Digno de nota é que as duas escolas que se saíram melhor do que a média da cidade pertencem ao PEA/BE.

Reiteramos que, apesar do desempenho escolar não ser o nosso foco, esse é um dado que observamos com cuidado, pois acreditamos que o reconhecimento da escola como uma instituição realmente importante para as famílias e para as crianças de origem popular passa, também, pelo reconhecimento de sua eficácia. Ou seja, passa pelo reconhecimento de sua capacidade de produzir bons resultados e de elevar o nível de aprendizado de seu público.

Mesmo os responsáveis cujas trajetórias escolares foram, na média, mais breves reclamam uma escola que tenha a capacidade de fazer com que seus filhos 
e filhas aprendam mais do que eles próprios aprenderam quando estiveram - em muitos casos isso nunca aconteceu - sentados nos bancos escolares.

Na sequência, o Gráfico 2 permite verificar os resultados de proficiência em Matemática dos alunos do $5^{0}$ ano do ensino fundamental na Prova Brasil.Apesar da inconstância nos resultados de algumas escolas, é possível verificar que as escolas da Maré evoluíram no desempenho em Matemática, na Prova Brasil. No entanto, com poucas exceções, o desempenho em Matemática das escolas da Maré se manteve abaixo da média da cidade do Rio de Janeiro.

\section{Gráfico 2 - Matemática- Prova Brasil escolas da Maré -2005 e 2015}

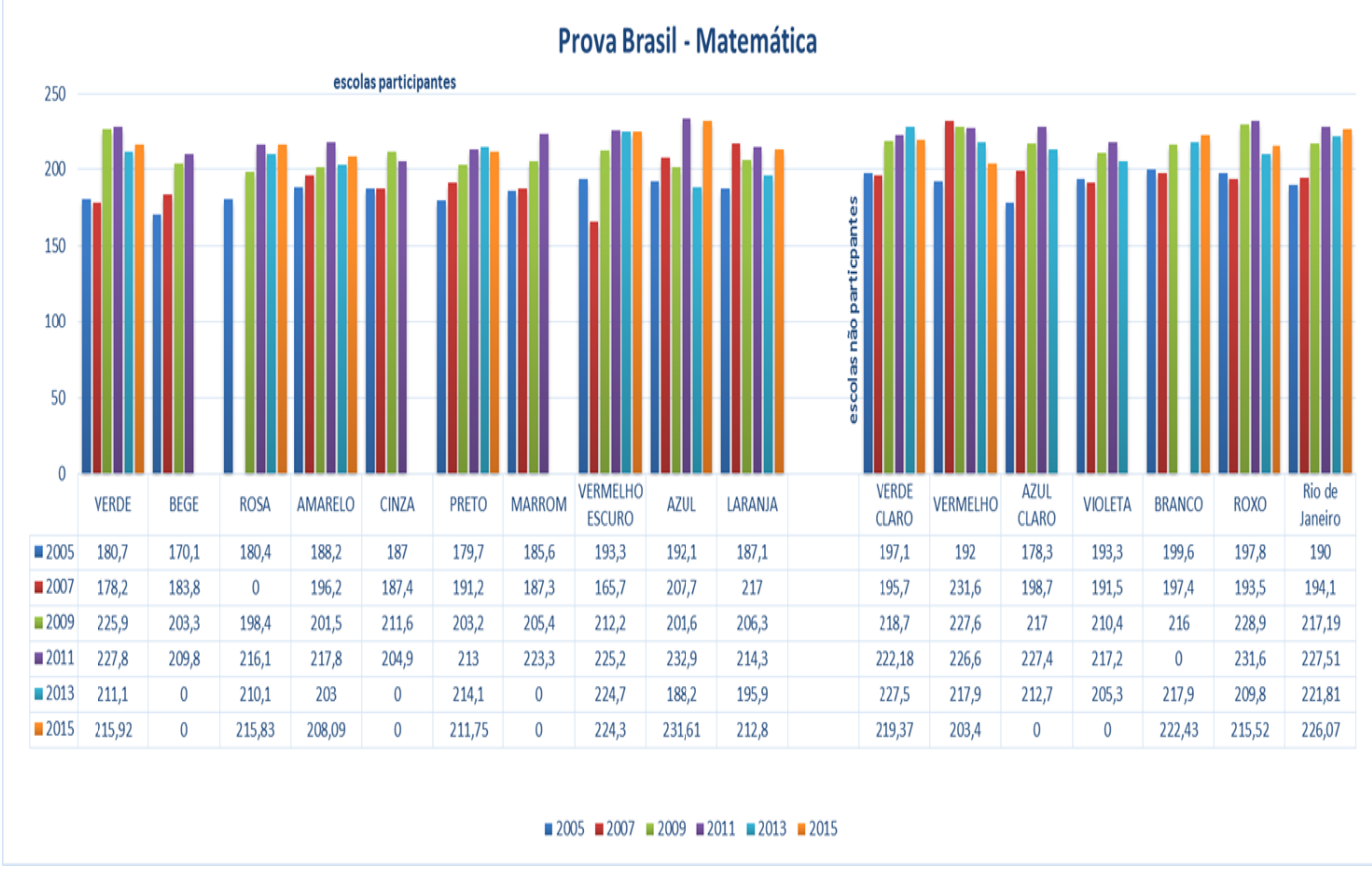

Fonte: Elaboração própria a partir do Inep

Se observarmos a série histórica do desempenho em Matemática das escolas na Maré, poderemos constatar que o número de escolas que superou a média da cidade vem caindo desde 2005. Neste ano, sete escolas superaram a média da cidade. Em 2007, esse número se manteve. Em 2009, foram apenas três escolas e em 2011 e 2013 apenas duas escolas ficaram acima da média da rede, e, mais recentemente, em 2015, apenas uma escola.

Quando observamos mais detidamente o ano de 2015, constatamos, por exemplo, que só a Escola Azul superou a média da rede municipal em proficiência em matemática. Ela atingiu o nível 5 da escala SAEB de proficiência, se situando no mesmo nível da cidade do Rio de Janeiro. As demais escolas, no entanto, se 
situam um nível abaixo, ou seja, no nível 4 da escala de proficiência de matemática do SAEB, com exceção da Escola Vermelho Escuro que obteve 224,3 pontos.É bom lembrar que essa escala para o $5^{\circ}$ ano é composta por nove níveis de proficiência, o que coloca as escolas da Maré na metade dessa escala, nos níveis abaixo do intermediário.

Quando observamos esses mesmos dados considerando as escolas participantes e não participantes do PEA, constatamos que, das sete escolas do grupo participante do PEA que possuem dados de proficiência em matemática para o ano de 2015, apenas uma conseguiu superar a média da cidade do Rio de Janeiro. Já entre as escolas que não participam do Programa nenhuma conseguiu sequer atingir a média da cidade.

No Gráfico 3, apresentamos os resultados de proficiência em língua portuguesa para o $5^{\circ}$ ano do ensino fundamental das escolas da Maré.Constatamos, com o gráfico, que as escolas da Maré se situam entre os níveis 3 e 4 da escala SAEB no que se refere à proficiência em língua portuguesa em 2015. Quando observamos as séries históricas, constatamos um quadro um pouco melhor do que o verificado em matemática, embora também haja queda constante no número de escolas que supera a média da rede de ensino do Rio de Janeiro em língua portuguesa.

\section{Gráfico 3 - Língua Portuguesa - Prova Brasil - escolas da Maré - 2005 e 2015}

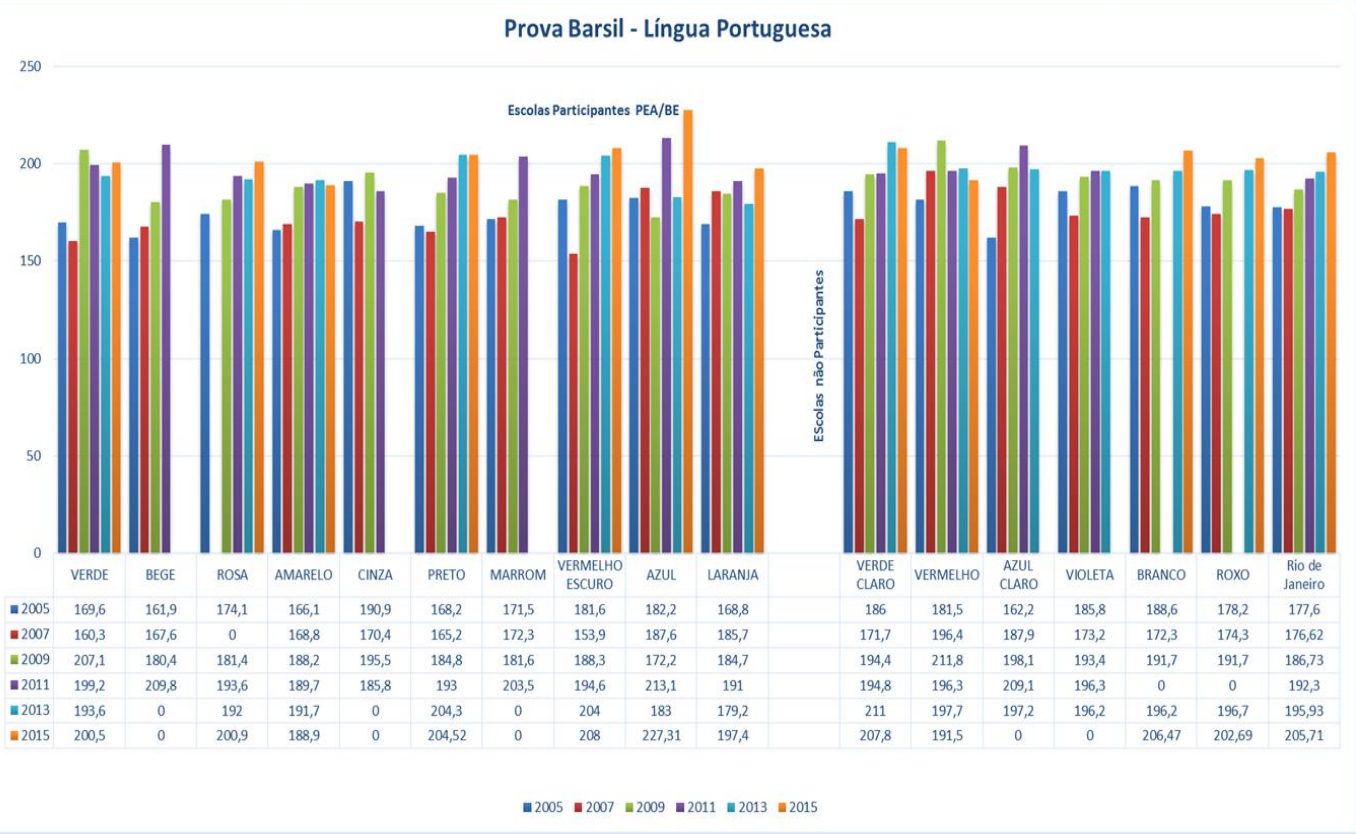


Fonte: Elaboração própria com dados do Inep

Em 2005, oito escolas superaram a média do Rio de Janeiro; em 2007, apenas quatro; em 2009, foram nove escolas; em 2011, esse número sobe para onze e, daí em diante, temos uma queda; em 2013, foram oito e, em 2015, apenas quatro escolas superaram a média da cidade.

Quando observamos os níveis de proficiência para o ano de 2015, verificamos que as escolas da Maré se encontram no mesmo nível da cidade, ou seja, no nível 4. Apenas uma das escolas - a Escola Azul - a mesma que superou o nível de proficiência da cidade em matemática se situa um nível acima, ou seja, no nível 5 da escala SAEB de língua portuguesa.

Comparativamente, podemos observar que houve uma pequena melhoria em termos de resultado geral para as escolas da Maré em língua portuguesa, quando cotejamos seus resultados com os da proficiência em matemática. Quando usamos o critério de pertencimento ou não ao PEA, temos o seguinte quadro: duas escolas do PEA e duas escolas não participantes do PEA conseguiram superar a média da cidade. Por último, o Gráfico 4 apresenta as taxas de aprovação nas escolas da Maré para alunos do $5^{\circ}$ ano do ensino fundamental. Esse é um dado também importante.

\section{Gráfico 4 - Taxas de aprovação dos anos iniciais das escolas da Maré entre} 2005 e 2015

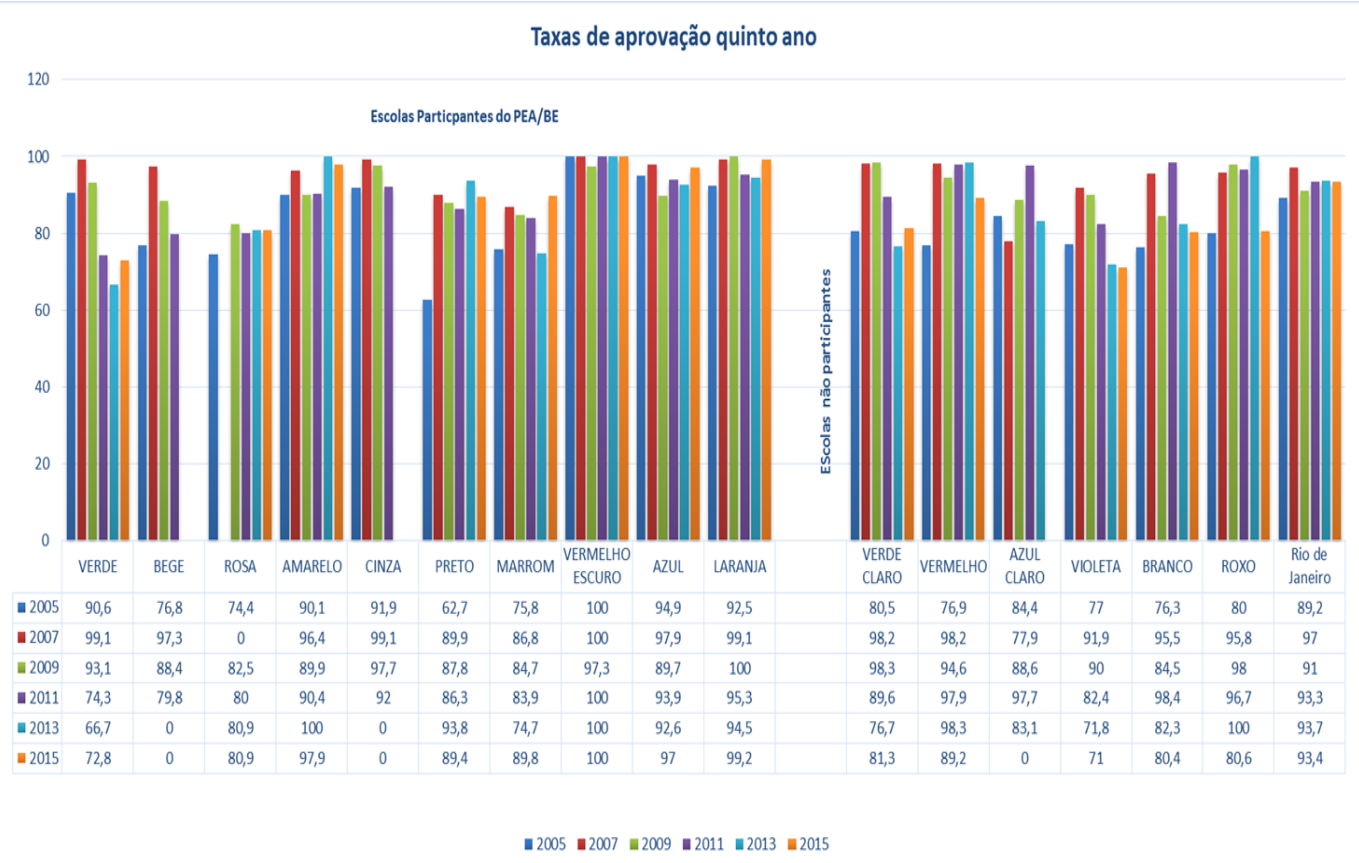

Fonte: Elaboração própria com dados do Inep 
Um dos maiores entraves à permanência das crianças de origem popular na escola é o fato de muitas delas experimentarem logo cedo a reprovação, uma das maiores causas da evasão escolar.

Não custa lembrar que o PEA/BE tem como um de seus objetivos principais diminuir a evasão escolar. Segundo dados do INEP, a taxa de aprovação para a cidade do Rio de Janeiro, para o ano de 2015, foi de 93,4\%. Quando observamos o Gráfico 4, que trata das taxas de aprovação das escolas da Maré para os anos iniciais do ensino fundamental, verificamos que apenas quatro escolas superaram a média da cidade. Todas as quatro escolas pertencem ao PEA/BE. No entanto, no mesmo grupo de escolas do PEA/BE, outras quatro escolas ficaram abaixo da média da cidade. Por essa razão, não é possível afirmar com segurança que o fato de participar do Programa contribuiu para a diminuição das taxas de evasão escolar,muito embora seja recomendável estudos adicionais comparativos entre as escolas que conseguiram diminuir a evasão e as que não conseguiram.

De todo modo, em conjunto, os indicadores das escolas da Maré mostram um quadro educacional preocupante, com uma grande variabilidade de resultados, tanto entre as escolas que participam quanto entre as escolas que não participam do PEA.

Embora os resultados de aprovação, no ano de 2015, sejam um pouco melhores no grupo de escolas participantes do PEA não há, quando observamos a série histórica, em relação à evolução da proficiência, diferenças substanciais entre as escolas participantes do PEA e as outras escolas da Maré.

Os indicadores apresentados oferecem um quadro geral de desempenho das escolas da Maré e, portanto, um panorama das dificuldades enfrentadas pelos agentes envolvidos no processo de escolarização das crianças da Maré. Nesse sentido, fica claro que existem desafios urgentes a serem vencidos no campo da educação na Maré, tais como a melhoria dos níveis de proficiência em Matemática e Língua Portuguesa e, principalmente, o combate à evasão escolar. 


\section{9 As percepções dos profissionais da escola e dos
responsáveis pelos alunos}

A escolha das escolas com as quais trabalhamos se deu a partir dos seguintes critérios: a) estar localizada em duas das dezesseis comunidades/favelas da Maré, cujas características socioeconômicas fossem semelhantes para que pudéssemos ter um grau de comparação confiável; b) ser uma escola atendida pelo PEA/Bairro Educador e outra não atendida; c) tivessem estruturas de funcionamento semelhantes, tais como o número de alunos e professores; d) que estivessem "dentro" das comunidades/favelas, ou seja, que estivessem no interior dos territórios; d) viabilidade e disponibilidade da equipe escolar para participar da pesquisa.

A partir desses critérios, foram escolhidas duas escolas para nossa pesquisa: a Escola Azul, que pertence ao PEA/BE e Escola Branca, que não pertence ao PEA/ BE. A seguir, faremos uma descrição dessas escolas e de sua vizinhança.

\section{1 \\ Escola Azul}

A Escola Azul, fundada em 1958, fica localizada em uma das ruas principais que dá acesso à comunidade/favela em que se situa. Seu prédio foi recentemente reformado e ampliado. A escola abriga aulas do ensino fundamental e atende a cerca de 520 alunos e alunas, que moram majoritariamente na comunidade/favela onde ela se localiza. A escola recebe, em menor número, alunos de comunidades vizinhas.

O acesso à escola é feito, a partir da rua principal da favela, por um portão central que dá acesso a um pátio descoberto. Esse pátio mede aproximadamente $40 \mathrm{~m}^{2}$. É nele onde se desenvolvem as atividades físicas. Além desse pátio, há um outro espaço, uma espécie de área de entrada ou um pátio interno, coberto, onde as crianças ficam perfiladas esperando as professoras todos as manhãs e tardes. Nesse espaço há um grande mural onde trabalhos escolares e avisos ficam expostos.

O fato interessante é que como a escola fica numa espécie de aclive - na subida de um morro - os responsáveis pelos alunos podem acompanhar a entrada 
de seus filhos em um plano mais alto, já que os pátios, tanto o externo quanto o interno, ficam em um plano inferior. Da rua, através de grades, os responsáveis observam a movimentação no interior da escola.

O prédio escolar é formado por dois andares. Existem duas escadas por onde as crianças acessam o andar superior onde se localizam as salas de aula. Há ainda um pequeno elevador - essa é a única escola na Maré que possui tal equipamento - que serve aos profissionais da escola. No andar térreo fica o refeitório, os banheiros e as salas da direção, das professoras e da coordenação. É, em geral, nessas salas que os responsáveis pelos alunos são atendidos.

O prédio está em ótimo estado de conservação. As salas são bem cuidadas e estão repletas de trabalhos escolares. Elas são equipadas com aparelhos de ar condicionado e outros equipamentos como tv, computador e projetor. Este aspecto, aliás, foi um dos pontos mais destacados pelas pessoas entrevistadas para este trabalho. Percebe-se que há um certo orgulho de estar em num espaço bem conservado e com bons recursos.

A sala das professoras - só havia um professor, o de Educação Física - é bem cuidada, embora pequena, e possui eletrodomésticos, como geladeira, forno de micro-ondas e televisão. Do mesmo modo, as salas da direção e da coordenação pedagógica também são bem pequenas, mas igualmente bem cuidadas.

A comunidade/favela onde se localiza a Escola Azul foi ocupada na década de 1940 e hoje conta com aproximadamente 7.000 moradores. Ela foi povoada a partir de um núcleo mais antigo formado por pescadores, que se localizava numa praia que existia na época de sua fundação - hoje aterrada pela Linha Amarela - e por outro núcleo de povoamento mais recente, justamente o que daria impulso à ocupação definitiva formada por trabalhadores que ajudaram a construir a Universidade do Brasil, hoje Universidade Federal do Rio de Janeiro, e a Avenida Brasil. (DINIZ, BELFORT, RIBEIRO, 2013).

Essa ocupação tem um fato curioso que ainda hoje repercute na composição social do lugar. Bem próximo à comunidade/favela, havia um destacamento do Exército Brasileiro - hoje deslocado para a Avenida Brasil - que afirmava ser o proprietário da área e que, por isso, tinha o direito de controlar a vida e a organização dos primeiros moradores. Foi assim que os militares definiram que só 
poderiam ocupar a nova comunidade/favela - ainda sem nenhum tipo de infraestrutura - aqueles que pudessem pagar as taxas cobradas por eles. Outra exigência dos militares era que as pessoas provassem algum vínculo empregatício que garantisse sua idoneidade (ibid.).

Tal controle só foi desfeito quando uma das moradoras, indignada com o controle do exército - havia a ideia de cercar o lugar com arame farpado e com a colocação de cancelas de entrada e saída - e com as taxas cobradas apresentou uma queixa ao então presidente Getúlio Vargas. Este, por sua vez, respondeu a moradora através de um telegrama, afirmando que ela não deveria pagar nada aos militares. Esse telegrama foi apresentado como salvo conduto para o não pagamento das taxas e os moradores passaram a se organizar para resistir ao domínio do exército.

O fato, porém, é que essa seleção inicial fez com que a comunidade/favela recebesse pessoas que tinham condições de vida um pouco melhores do que as pessoas que chegaram a outros pontos da Maré. Isso permanece como marca dessa comunidade/favela ainda hoje.

Em termo de renda per capita, por exemplo, os moradores dessa comunidade/favela possuem um nível um pouco mais alto do que as outras comunidades/favelas da Maré. Esse fato se reflete na qualidade do material de construção utilizado nas casas, no próprio tamanho destas e nos bens materiais, como carros mais novos e o uso de tevê a cabo regularizada.

No que se refere a equipamentos culturais e instituições existem ONGs, igrejas, um museu e uma escola de samba que movimentam a vida social e cultural local. O comércio é de pequeno porte, formado basicamente por pequenos mercados, salões de beleza, bares e restaurantes (REDES, 2014). É uma das poucas comunidades/favelas da cidade que possui uma rádio comunitária, que pode ser ouvida em frequência modulada (FM).

O acesso da comunidade/favela para a Avenida Brasil é feito por uma rua principal larga, conectada às ruas menores que a ligam a outras comunidades/favelas próximas como e com as saídas para a Linha Amarela e Vermelha. Como as demais comunidades/favelas da Maré, ela também sofre com a presença de grupos criminosos armados que impõem seu domínio sobre o território. Muitas vezes as disputas entre grupos rivais pelo controle do comércio 
de drogas ou os confrontos com a polícia paralisam a vida e interferem no funcionamento das instituições locais, como a Escola Azul.

Contudo, mesmo com essas dificuldades, há uma forte organização comunitária. Isso porque, como dito acima, os primeiros moradores, tendo de fazer o contraponto à forte presença dos militares no início, criaram uma Associação de Moradores, uma das primeiras da cidade, que passou a organizar os moradores para a resolução de problemas como a falta de água, luz, asfalto e a permanência no território, pois sempre pairava a ameaça de remoção (DINIZ, BELFORT, RIBEIRO, 2013). Hoje, embora a Associação de Moradores não tenha mais o papel de liderança como no passado, ela continua sendo uma instituição importante na organização da vida comunitária.

\section{2 \\ Escola Branca}

A Escola Branca é uma das mais antigas da Maré, pois sua fundação remete ao ano de 1961, quando a própria Maré ainda se consolidava. Sua escolha para este trabalho se deu, entre outras questões, exatamente por ser a única escola não participante do PEA/Bairro Educador que se localiza no interior de uma das comunidades/favelas da Maré.

Seu terreno fica localizado próximo à praça central da comunidade/favela e o prédio escolar tem a forma de um retângulo com aproximadamente 500 metros de extensão por onde se distribuem as salas de aula, não existindo pavimento superior.

Entre as salas de aula, há um pequeno pátio coberto que se comunica com duas quadras esportivas - sendo uma delas coberta - e um extenso corredor que serve de circulação para professores, alunos e demais funcionários. A direção da escola fica localizada em uma das salas próxima ao portão principal de entrada e, no lado oposto, fica a sala de professores.

As salas da direção e dos professores são pequenas e a estrutura mostra sinais de desgaste por conta do tempo. A impressão que se tem ao chegar é a de que ambas as salas foram "improvisadas", pois não há uma organização seletiva do espaço. Livros e papéis de toda ordem convivem com quadros de aviso, material pedagógico e objetos os mais variados. Há certo aspecto de "desordem" 
aparente na forma de arrumação das salas de diretores e professores. À primeira vista, tem-se a impressão de que esses espaços não foram planejados, ao contrário, foram sendo constituídos a partir das demandas cotidianas e, por isso, o "ar de improviso" predomina.

No portão de entrada principal - há outro lateral por onde entram as crianças menores - existe uma série de avisos colocados nas grades. O fato mais curioso é que em alguns desses avisos os nomes, endereços e telefones de responsáveis pelas crianças ficam exposto à vista de todos que por ali circulam. Esse fato parece não incomodar a escola.

A Escola Branca atende majoritariamente alunos e alunas que vivem em duas comunidades/ favelas próximas. As crianças - aproximadamente 500 - estão matriculadas nos anos iniciais do ensino fundamental. $\mathrm{O}$ acesso dos moradores se faz pelo interior das duas comunidades/favelas através de caminhos estreitos formados por becos e vielas. Mas há também uma rua mais larga que se comunica diretamente com a Avenida Brasil, por onde chegam os profissionais da escola. Ao todo, as duas comunidades atendidas pela Escola Branca possuem mais de 10 mil moradores.

Próximo à escola, na verdade, em frente a ela, existe uma praça com vários "quiosques" que servem comida e bebida e que funcionam à noite e nos finais de semana; há ainda um pequeno palco em que grupos musicais variados se apresentam também nos finais de semana.

Mais à frente há uma praia, tão famosa no subúrbio carioca quanto poluída, mas que, mesmo assim, é muito frequentada por moradores e por pessoas que vêm da Baixada Fluminense e de bairros da zona norte da cidade. Do lado direito do prédio escolar, existe um posto de saúde e, junto a este, um posto policial.

A comunidade/ favela possui uma pequena rua principal, onde se localiza o comércio e onde funciona, aos sábados, uma feira livre. É no entorno dessas ruas que o pequeno comércio local de desenvolve. Há uma variedade grande de pequenas lojas de roupas e alimentos e até um supermercado de médio porte. $\mathrm{O}$ acesso dos carros também se faz por estas vias, já que no interior das duas comunidades/favelas às quais a Escola Branca atende não há espaço para o trânsito de automóveis. 
$\mathrm{Na}$ questão da segurança pública, as comunidades/favelas também sofrem com a falta de uma política pública que garanta aos moradores os seus direitos básicos. Há, no entanto, um fato que diferencia a vizinhança da Escola Branca das demais das demais comunidades/favelas que constituem a Maré: elas são controladas por grupos paramilitares, as chamadas milícias. Esses grupos expulsaram, há pelo menos 10 anos, um grupo de traficantes de drogas e se estabeleceram no território das duas comunidades atendidas pela Escola Branca.

A milícia controla atividades econômicas ligadas à venda de botijão de gás - produto de extrema importância nas comunidades/favelas -, além de transporte alternativo, sinal de televisão clandestino e venda de segurança privada. É sabido que esse grupo impõe seu controle sobre o território a partir da força e isso cria medo e tensão nas comunidades.

Porém, nessas comunidades/favelas há uma intensa vida comunitária. Existem grupos musicais variados - foi daí que surgiu o Cantor Dicró, por exemplo, um dos mais irreverentes cantores da MPB - pequenas academias de dança, grupos de teatro amadores e uma variedade de iniciativas culturais dos jovens que se encontram nos espaços como as praças, que existem junto à Praia de Ramos.

Existe também uma Vila Olímpica da Prefeitura, administrada por uma organização social, que atende aos moradores com projetos esportivos. Essa instituição mantém parceria coma Escola Branca, realizando oficinas de circo, dança e levando os alunos e alunas para realizarem atividades esportivas em suas dependências.

Por fim, abaixo apresentamos um quadro comparativo de rendimentos por faixa de renda. Ele nos permite observar as semelhanças e diferenças das populações atendidas pela Escola Azul e pela Escola Branca.

\section{Quadro 1 - rendimentos}

\begin{tabular}{|l|c|c|c|c|}
\hline \multicolumn{1}{|c|}{ Comunidade } & 0 a 1 SM & 1 a 2 SM & 3 a 6 SM & 7 ou mais SM \\
\hline Escola Azul & 1,58 & 60,9 & 31,75 & 5,79 \\
\hline Escola Branca & 5,97 & 60,4 & 31,34 & 2,24 \\
\hline
\end{tabular}

Como se pode observar, as faixas de renda da população atendidas variam entre um e sete salários mínimos. Nas faixas de rendimentos entre 1 e 2 salários, e 
entre 3 e 6 salários, os percentuais são quase idênticos, o que indica uma tendência a igualar as condições econômicas e as condições de vida da maioria dos moradores das comunidades/favelas onde se localizam as escolas aqui estudadas.

Há, no entanto, uma diferença importante quando olhamos para os extremos do quadro: verificamos que a comunidade/favela atendida pela Escola Azul tem um rendimento superior, pouco mais do dobro, na faixa de rendimentos com mais de sete salários mínimos. Na outra ponta, ou seja, a renda mais baixa, a comunidade atendida pela Escola Branca tem quase o triplo, quando comparada à Escola Azul, de pessoas na faixa de rendimentos de 0 a 1 salário mínimo.

\section{3}

\section{Sobre as entrevistas}

Foram realizadas, no total, dezesseis entrevistas - oito em cada uma das escolas - com profissionais das escolas e com familiares dos alunos. O Quadro 2apresenta os sujeitos entrevistados em cada uma das escolas participantes da pesquisa e como são classificados.

\begin{tabular}{|c|c|}
\hline ESCOLA AZUL & SCOLA BRANCA \\
\hline $\begin{array}{l}\text { Diretora: profissional com mais de } 15 \text { anos } \\
\text { no magistério; dirige a escola a pouco mais } \\
\text { de } 3 \text { anos; já exerceu cargos na } \\
\text { administração de outras escolas na própria } \\
\text { Maré; mora em outra cidade e vai à escola } \\
\text { de carro; tem } 40 \text { anos de idade. }\end{array}$ & $\begin{array}{l}\text { Diretora: profissional com } 30 \text { anos de } \\
\text { magistério; dirige a escola há } 25 \text { anos; } \\
\text { mora em outro bairro da cidade; cai } \\
\text { para a escola de carro; tem } 60 \text { anos de } \\
\text { idade. }\end{array}$ \\
\hline $\begin{array}{l}\text { Diretora adjunta: profissional com mais de } \\
15 \text { anos de magistério; atua nessa função } \\
\text { há } 3 \text { anos; mora em outro bairro da cidade } \\
\text { e vai à escola de carro; tem } \\
\text { aproximadamente } 35 \text { anos de idade. }\end{array}$ & $\begin{array}{l}\text { anos de magistério; está } \\
25 \text { anos; mora em outr } \\
\text { cidade; vai para a escola c } \\
\text { público; tem } 58 \text { anos de id }\end{array}$ \\
\hline $\begin{array}{l}\text { Professora 1: profissional com } 8 \text { anos de } \\
\text { magistério; está na escola há } 5 \text { anos; é } \\
\text { moradora da Maré; vai para a escola a pé; } \\
\text { conhece bem a comunidade/favela; tem } 38 \\
\text { anos de idade }\end{array}$ & $\begin{array}{l}\text { Professor 1: profissional com } 25 \text { anos } \\
\text { de magistério; atua na escola há } 15 \\
\text { anos; já atuou em escolas localizadas } \\
\text { em outras favelas; mora em outro } \\
\text { bairro da cidade; vai para a escola de } \\
\text { carro; tem } 43 \text { anos de idade. }\end{array}$ \\
\hline $\begin{array}{l}\text { Professora 2: profissional com } 10 \text { anos de } \\
\text { magistério; lecionada na escola há } 7 \text { anos; } \\
\text { mora em outra cidade e chega à escola de } \\
\text { carro; nunca havia atuado em escolas }\end{array}$ & $\begin{array}{l}\text { Professora 2: profissional com } 15 \text { anos } \\
\text { de magistério; atua na escola há } 15 \\
\text { anos; nunca trabalhou em outra } \\
\text { escola; mora em um bairro próximo da }\end{array}$ \\
\hline
\end{tabular}




\begin{tabular}{|c|c|}
\hline $\begin{array}{lcc}\text { localizadas em favela; } & \text { tem } \\
\text { aproximadamente } 50 \text { anos de idade. } & \end{array}$ & $\begin{array}{l}\text { escola; vai a pé para a escola; tem } 35 \\
\text { anos. }\end{array}$ \\
\hline $\begin{array}{l}\text { Agente administrativo: profissional com } 10 \\
\text { anos de experiência na função; já atuou em } \\
\text { outras escolas da Maré; antes de ser } \\
\text { agente administrativo era professor de } \\
\text { dança de salão; mora fora da } \\
\text { comunidade/favela; utiliza transporte } \\
\text { público para chegar à escola; tem } 40 \text { anos } \\
\text { de idade. }\end{array}$ & $\begin{array}{l}\text { Agente administrativo: profissional } \\
\text { com } 10 \text { anos de experiência (não fez } \\
\text { concurso para o cargo que exerce, foi } \\
\text { "adaptada" na função); atua na escola } \\
\text { há } 10 \text { anos; trabalhou em outras } \\
\text { escolas da Maré, em outras funções; } \\
\text { mora na comunidade/favela; tem } 30 \\
\text { anos de idade. }\end{array}$ \\
\hline $\begin{array}{l}\text { Mãe de aluno 1:Tem um filho na escola; } \\
\text { mora na comunidade/favela desde criança; } \\
\text { responsável pela relação da família com a } \\
\text { escola; leva e traz o filho todos os dias; é } \\
\text { mãe de outra criança que necessidade } \\
\text { cuidados especiais e estuda em outra } \\
\text { escola da Maré também atendida pelo } \\
\text { PEA/BE; estudou até o ensino médio; tem } \\
45 \text { anos de idade. }\end{array}$ & $\begin{array}{l}\text { Mãe de aluno: Tem um filho } \\
\text { matriculado na escola; mora na } \\
\text { comunidade/favela há mais de } 20 \\
\text { anos; responsável pela relação com a } \\
\text { escola; possui o ensino fundamental } \\
\text { incompleto; tem } 45 \text { anos de idade. }\end{array}$ \\
\hline $\begin{array}{l}\text { Mãe de aluno 2: tem dois filhos na escola; } \\
\text { mora próximo a escola; cresceu na } \\
\text { comunidade/favela; responsável pelo } \\
\text { acompanhamento escolar das crianças; } \\
\text { tem o ensino fundamental incompleto; } \\
\text { tem } 35 \text { anos de idade. }\end{array}$ & $\begin{array}{l}\text { Avó de aluno: tem uma neta } \\
\text { matriculada na escola; mora na } \\
\text { comunidade/favela há } 30 \text { anos; é } \\
\text { responsável pela educação escolar, } \\
\text { pois a mãe da criança trabalha fora de } \\
\text { casa; estudou até as séries iniciais do } \\
\text { ensino fundamental; tem } 60 \text { anos de } \\
\text { idade. }\end{array}$ \\
\hline $\begin{array}{l}\text { Avô de aluno: tem uma neta na escola; } \\
\text { mora na comunidade/favela há } 60 \text { anos; } \\
\text { estudou na escola quando criança; tem o } \\
\text { ensino fundamental completo; é o } \\
\text { responsável, junto com a esposa, pelo } \\
\text { acompanhamento escolar da criança; tem } \\
65 \text { anos de idade. }\end{array}$ & $\begin{array}{l}\text { Pai de aluno: tem um filho matriculado } \\
\text { na escola; responsável pelo } \\
\text { acompanhamento escolar, pois tem } \\
\text { horários mais flexíveis do que a } \\
\text { esposa; estudou na escola quando } \\
\text { criança; mora na comunidade/favela } \\
\text { desde que nasceu; fez o ensino médio; } \\
\text { tem } 23 \text { anos de idade. }\end{array}$ \\
\hline $\begin{array}{l}\text { Gestora da ONG que dirigiu o Projeto } \\
\text { Bairro Educador: Profissional com } \\
\text { formação na área de pedagogia; atua na } \\
\text { instituição há mais de } 10 \text { anos; tem } \\
\text { experiência em outros projetos que } \\
\text { também foram executados em favelas } \\
\text { cariocas; fez pós-graduação na área de } \\
\text { educação, tem } 45 \text { anos de idade. }\end{array}$ & \\
\hline
\end{tabular}

Todas as entrevistas com os responsáveis foram realizadas no espaço escolar e o contato com as famílias se deu através das escolas. Ressaltamos queas instituições não colocaram qualquer tipo de impedimento e franquearam as 
condições para que as entrevistas acontecessem. Assim como as escolas, a $4^{\mathrm{a}} \mathrm{CRE}$ e a SME-RJ, não criaram nenhum tipo de obstáculo para a pesquisa de campo.

A ideia de realizar as entrevistas nas dependências das escolas levou em consideração a disponibilidade das famílias e o fato desse contexto possibilitar ir além dos depoimentos, no sentido de identificar outros elementos que nos permitissem perceber nuances de como se dão as interações escola-família.

O que pudemos perceber, logo de início, é que os profissionais da escola optaram por falar nos espaços formais, como as salas de direção, de coordenação e de professores. Já no caso dos familiares dos alunos a opção recaiu sobre os espaços informais, e as entrevistas aconteceram majoritariamente em pátios e em áreas externas da escola.

Embora não tenhamos elementos suficientes para explicar estas opções diferenciadas, não podemos deixar de levar em conta que o funcionamento da escola é fruto de múltiplas relações entre a estrutura formal e agentes com interesses e posições diversas. Nesse sentido, os modos escolares de regulação e de gestão das relações, inclusive e principalmente das relações escola-família, se dão em um contexto hierarquicamente estruturado em postos, funções e normatizações, que envolvem a organização da escola em espaços físicos e em um conjunto de relações entre os diferentes atores que transitam e participam no diaa-dia da escola, que desempenham papeis e ocupam lugares hierarquicamente diferenciados (ENGUITA, 1991; FORQUIN, 1993; DEROUET, 1995; DAYRELL, 1996; DUBAR, 1997).

No espaço escolar assim caracterizado, os espaços formais e hierarquicamente estruturados foram escolhidos pelos profissionais da escola para serlugar de fala, o lugar das entrevistas, ao passo que os espaços não estruturados, como as áreas externas e o pátio, onde acontecem com maior frequência encontros e interações informais, sem direção e intencionalidade, foram escolhidos pelas famílias para as entrevistas. Outra observação a ser feita diz respeito ao tempo de duração das entrevistas, que, salvo duas exceções, foi bem maior no caso dos profissionais da escola do que no caso das famílias.

Nossa hipótese, neste caso, é que os responsáveis disporiam de menos elementos para discutir temas escolares, isto é, que conheceriam menos "o jogo escolar" e teriam menos elementos para questionar a rotina escolar e seus ritos. 
Apesar disso, ficou evidente o interesse das famílias entrevistadas pela escola. Trata-se de famílias com estruturas e volumes de capital cultural e econômico diferenciados, que investem na escolaridade e se mostram, sem exceção, preocupadas com os resultados escolares de suas crianças. Isto foi percebido tanto na escola participante do $\mathrm{PEA} / \mathrm{BE}$, quanto na escola não participante.

No caso dos profissionais das escolas, as entrevistas, com poucas exceções, foram mais longas e demonstraram ter um conhecimento maior da rotina escolar. As entrevistas levaram em conta o lugar ocupado por esses agentes, sua compreensão da escola e do seu funcionamento, as questões geradas pela localização da instituição na Maré e pela relação com as famílias dos alunos.

As entrevistas com os gestores do programa - tanto os que pertencem ao quadro da SME-RJ, quanto aos que pertencem à ONG executora do Bairro Educador -também foram mais longas e nos permitiram perceber o quanto o PEA/BE ganhou interpretações diferentes de acordo com a posição que cada um dos entrevistados ocupou no Programa. Durante as entrevistas e durante a observação de campo com duração de quatro meses, optamos por fazer algumas visitas às escolas sem marcação prévia para que pudéssemos, de fato, encontrá-las funcionando dentro de sua rotina normal, sem se preocupar com a visita de um pesquisador externo. Pelo que pudemos perceber, isso funcionou bem e os dados de que dispomos indicam que essa opção foi acertada.

\section{4}

\section{Categorias de análise}

A partir do levantamento bibliográfico e das discussões teóricometodológicas feitas anteriormente, estabelecemos algumas categorias de análise do material das entrevistas que estão no campo das discussões acerca das relações escola-família-vizinhança. São elas: 1. Relação escola-família (relações antinômicas, relações armadilhadas); 2. Efeito vizinhança (geografia das oportunidades); 3. Mundo do Aluno.

O Quadro abaixo, detalha cada uma dessas categorias. 
Quadro 3 - Categoria de análise

\begin{tabular}{|c|c|c|}
\hline Categoria & Operacionalização & $\begin{array}{l}\text { Referências nas entrevistas e } \\
\text { observações }\end{array}$ \\
\hline Mundo do aluno & $\begin{array}{l}\text { Caracterização dos } \\
\text { alunos fora da escola a } \\
\text { partir de sua casa e de } \\
\text { seu território. }\end{array}$ & $\begin{array}{l}\text { Compreender de que maneira } \\
\text { os profissionais da escola } \\
\text { interpretam e qualificam a } \\
\text { "casa" e o "lugar" do aluno. } \\
\text { Como julgam que a cultura do } \\
\text { aluno apreendida na casa e no } \\
\text { território influencia na relação } \\
\text { deste com a escola. }\end{array}$ \\
\hline $\begin{array}{l}\text { Efeito } \\
\text { vizinhança:geografias } \\
\text { objetiva, subjetiva e } \\
\text { de oportunidades }\end{array}$ & $\begin{array}{l}\text { Quantidade e qualidade } \\
\text { das ofertas de } \\
\text { oportunidades } \\
\text { educacionais, } \\
\text { econômicas e sociais } \\
\text { geradas por instituições } \\
\text { diversas no lugar onde se } \\
\text { localiza a escola. } \\
\text { Circulação das } \\
\text { informações e } \\
\text { apropriação por parte de } \\
\text { escolas e famílias. }\end{array}$ & $\begin{array}{l}\text { Julgamento dos profissionais } \\
\text { da escola e familiares da } \\
\text { influência do território sobre a } \\
\text { escola e sobre a escolarização } \\
\text { das crianças. } \\
\text { Compreensão da maneira } \\
\text { como os profissionais da } \\
\text { escola e familiares avaliam as } \\
\text { oportunidades objetivas } \\
\text { oferecidas pelo território e } \\
\text { como eles se apropriam ou } \\
\text { não delas. } \\
\text { Julgamento do território a } \\
\text { partir da avaliação do que ele } \\
\text { pode oferecer em termos de } \\
\text { oportunidade. }\end{array}$ \\
\hline $\begin{array}{l}\text { Relação escola- } \\
\text { família: relações } \\
\text { antinômicas e } \\
\text { relações } \\
\text { armadilhadas }\end{array}$ & $\begin{array}{l}\text { Quantidade de encontros } \\
\text { e reuniões entre } \\
\text { profissionais da escola e } \\
\text { responsáveis pelos } \\
\text { alunos; tipo e frequência } \\
\text { da comunicação entre } \\
\text { profissionais da escola e } \\
\text { responsáveis pelos } \\
\text { alunos; possibilidades } \\
\text { reais de intervenção dos }\end{array}$ & $\begin{array}{l}\text { Tipo de famílias e arranjos } \\
\text { familiares dos estudantes; } \\
\text { Qualificação dos contatos e } \\
\text { das relações estabelecidas } \\
\text { entre profissionais da escola e } \\
\text { familiares; } \\
\text { Avaliação do comportamento } \\
\text { do aluno, das } \\
\text { responsabilidades da família e } \\
\text { do território por esse } \\
\text { comportamento; } \\
\text { Entendimento da maneira da } \\
\text { família incorporar ou não as }\end{array}$ \\
\hline
\end{tabular}




\begin{tabular}{|l|l|l|}
\hline & $\begin{array}{l}\text { responsáveis pelos } \\
\text { alunos nos espaços } \\
\text { escolares. }\end{array}$ & $\begin{array}{l}\text { demandas escolares, assim } \\
\text { como a distância gerada entre } \\
\text { essas instituições } \\
\text { socializadoras; }\end{array}$ \\
& $\begin{array}{l}\text { Entendimento da maneira } \\
\text { como os profissionais da } \\
\text { escola e as famílias } \\
\text { identificam problemas e } \\
\text { possíveis "ciladas" que se } \\
\text { colocam na relação entre } \\
\text { ambas instituições. }\end{array}$ \\
& $\begin{array}{l}\text { Identificação da maneira pela } \\
\text { qual os profissionais da escola } \\
\text { definem a participação dos } \\
\text { familiares nos encontros } \\
\text { formais e da avaliação que } \\
\text { fazem dos mesmos. }\end{array}$ \\
\hline
\end{tabular}

\subsection{1 \\ 0 mundo do aluno}

Usamos o conceito de "mundo do aluno" (BURGOS, 2014) para definir o universo subjetivo e objetivo das crianças que chegam às escolas públicas. Esse universo é composto pelas relações familiares, pelas condições de vida e as características do território em que vivem as crianças.

Conhecer o mundo do aluno, sem dúvidas, deveria ser o primeiro passo para todas as escolas, principalmente para aquelas que atuam nas regiões mais pobres e vulneráveis da cidade, como é o caso da Favela da Maré. Isso porque só é possível criar condições de aprendizagem eficazes se as escolas reconhecerem as especificidades do lugar e do público que acolhem nesses territórios. Na prática, no entanto, o que se percebe é que a maioria das escolas continua a trabalhar e a desenvolver suas atividades a partir de projeções sobre a figura de um aluno ideal que não corresponde à realidade.

Por outro lado, é impressionante o quanto as escolas da Maré, mesmo as mais antigas, e seus profissionais desconhecem o universo dos alunos. Alguns profissionais da escola até reconhecem as crianças por seus nomes, sabem onde moram, mas não entendem o seu mundo. Não conhecem “o sujeito por trás do aluno" (ibid.). 
Esse desconhecimento cria barreiras que dificultam o estabelecimento de uma boa relação entre as escolas, as famílias e os alunos. Por isso, quando criamos nosso roteiro de entrevistas, (ver anexo) uma de nossas primeiras preocupações foi justamente inquirir os profissionais das escolas e os formuladores do PEA/BE sobre o grau de conhecimento que detinham a respeito do que estamos chamando de mundo do aluno. Assim, começamos reproduzindo e analisando alguns trechos de entrevistas à luz desse conceito. $\mathrm{O}$ primeiro trecho, transcrito abaixo, é de um dos professores da Escola Branca, que não participa do PEA/BE.

Ao se referir ao mundo do aluno, o professor faz as seguintes observações.

..eles ficam presos a isso aqui, isso é um limite. Se eles
tivessem uma formação acadêmica melhor, se lessem mais, se
se informassem mais... eles tão, naquilo que falei, no
comodismo, tá ali na questão da sobrevivência, vai, volta, tem a
rotina, mas não é uma rotina saudável. Passa a ser nociva
depois de um certo tempo para a própria criança dele [...]
porque quando você tem um pouco mais de conhecimento, você
procurara ampliar mais as coisas, vai ampliando, cria a
curiosidade que é o que a gente procura fazer aqui na escola
(Professor da Escola Azul).

Outra professora da mesma escola faz um depoimento semelhante.

[...] acho que eles não têm expectativa de sair daqui, procurar coisa melhor, ficam muito fechados aqui na comunidade [...] tem aluno que nem saiu daqui ainda, nem para um shopping, alunos que ficam de segunda a segunda aqui dentro, aí vai passar na passarela [passarela de pedestres que liga a favela ao outro lado da Avenida Brasil] é uma festa, expectativa de sair não tem (Professora da Escola Branca).

É interessante observar como os professores caracterizam o mundo dos alunos a partir da ideia de "gueto" e de uma visão homogeneizadora. Assim, há uma referência forte ao enclausuramento das crianças no seu mundo, tanto no que se refere ao espaço físico quanto ao simbólico, e uma concepção de homogeneidade que não enxerga diferenças entre os diversos grupos que compõem o corpo discente.

No capítulo no qual tratamos das características da Maré, pudemos observar que, apesar dos baixos indicadores socioeconômicos, as diferentes comunidades/favelas não são homogêneas e que há uma heterogeneidade que precisa ser considerada. Nesse sentido, existem comunidades/favelas com índices socioeconômicos melhores e piores e com diferenças culturais e históricas entre 
elas. Como é o caso, por exemplo, das comunidades atendidas pelas escolas a que pertencem os professores. Quando comparamos os depoimentos dos profissionais da Escola Branca (não participante do PEA/BE) com os depoimentos de profissionais da Escola Azul (participante do PEA/BE), verificamos que os últimos conseguem perceber diferença nos grupos que compõem o corpo docente e não definem o mundo do aluno a partir de uma "visão de gueto".

Ao ser indagada sobre o perfil das crianças que frequentam a escola, uma das pessoas que faz parte da equipe de direção da Escola Azul responde da seguinte maneira:

As famílias são bem diversas[...] tenho famílias que são muito pobres, tenho famílias em situação melhor. [...] A gente vê no Facebook as viagens que são feitas. No contraponto, tem aqueles que vivem com a renda do Bolsa Família [...]. É uma mistura social muito grande [...]. Eu tenho um estudo que mostra que a maioria das crianças é da comunidade A e B, mas tenho de outros lugares da Maré também e até tenho uma de fora (Diretora da Escola Azul).

De forma complementar, outra pessoa entrevistada, que também faz parte da equipe de direção escolar, qualifica as crianças de modo bem parecido:

[...]agente tem alguns alunos bem 'pobrezinhos', alguns se alimentam aqui na escola, em casa a alimentação é precária e [...] tem um grupo que é uma 'classe média' razoável, e uma minoria que tem uma condição financeira boa. Estão bem mesclados. (Diretora adjunta da Escola Azul).

Essa constatação é reafirmada quando, durante as entrevistas, uma das pessoas da equipe de direção ressalta a existência de fotos divulgadas, pelas famílias, em uma rede social como prova de que as crianças saem da Maré, e também viajam.

De todo modo, é razoável supor que o estudo feito pela direção da Escola Azul sobre a diversidade de regiões da Maré de onde vêm seus alunos tenha algum tipo de influência sobre a visão que a escola construiu a respeito de uma maior heterogeneidade de seu público.Contudo, não é possível afirmar com segurança que a diferença de percepção entre a Escola Azul e aEscola Brancaguarde relação direta com o fato de elas pertencerem ou não ao PEA/BE. O que nos pareceu, a partir das entrevistas e das observações que realizamos, foi que a iniciativa de fazer um levantamento da origem dos alunos, realizada pela equipe 
de direção da Escola Azul, se deu por iniciativa da escola e não por uma orientação do programa.

Por outro lado, não há evidencias de que os profissionais das escolas, tanto da Escola Azul, quanto da Escola Branca, tenham um contato maior com o território e com as crianças fora do espaço escolar. A exceção diz respeito aos professores ou membros das equipes técnicas, uma minoria, que também mora nas próprias favelas/ comunidades.

De uma forma geral, o que ficou claro durante as entrevistas e as visitas às escolas é que é bem limitado o contato entre as escolas e o que chamamos aqui de o mundo do aluno. O depoimento de uma das gestoras que coordenou mais de perto o trabalho do Bairro Educador deixa mais claro o quanto ainda é distante o mundo escolar do mundo do aluno. Quando perguntada sobre como a equipe de campo da instituição fazia contato com as famílias, ela afirmou que:

Íamos de casa em casa. A escola indicava os alunos ou grupos de alunos que considerava que precisavam de mais atenção $e$ nós fazíamos as visitas. Não eram visitas como as da equipe social, procurávamos separar bem isso. $O$ que a gente fazia eram visitas de conversação com essas famílias [...]. Era uma visita convite para que a família fosse até a escola conversar sobre aquilo que estava acontecendo [...]. A gente pedia para a equipe pedagógica[da escola]para também se preparar para receber essa família de maneira diferente. Então, o que a gente fazia, na verdade, era criar uma melhor ambientação tanto na hora de receber a família quanto na hora de conversar com essa família. A gente preparava as duas pontas (Gestora do Bairro Educador).

Esse depoimento permite perceber o grau de mediação feita entre os dois mundos, o mundo escolar e o mundo do aluno, pois, a ideia de preparar "as duas pontas" revela a distância entre ambos os mundos. Na verdade, pelo que pudemos observar, na maioria dos casos, os contatos entre os profissionais da escola e os responsáveis ficaram restritos às reuniões ou a algumas ocasiões especiais como eventos e festas, e às conversas esporádicas na entrada e saída das crianças. Nesses momentos, em meio à algazarra e às brincadeiras das crianças, alguns responsáveis abordavam ou eram abordados pelos profissionais da escola para tratar de assuntos mais específicos, geralmente sobre o comportamento de seus filhos e filhas. 
Constatamos também que não havia espaços, em nenhuma das duas escolas, onde professores e responsáveis pelos alunos pudessem conversar. Não havia ainda nenhuma representação de grupos de pais, mesmo que as direções nos tenham informado que o Conselho Escola Comunidade (CEC) estivesse constituído. Nas entrevistas com os responsáveis pelos alunos, ao serem indagados sobre a representação de pais, eles simplesmente desconheciam qualquer iniciativa nesse sentido.

\subsection{2 \\ O efeito vizinhança e a geografia objetiva e subjetiva das}

Como vimos anteriormente, o conceito de efeito-vizinhança, ou efeitobairro, carrega consigo a ideia de que o lugar, bairro, território ou vizinhança mantém forte influência sobre seus habitantes. As redes sociais, as condições materiais, a distribuição de bens e serviços ou a falta destes impacta a vida cotidiana e conforma as relações sociais estabelecidas localmente.

É o caso, por exemplo, de territórios marcados pela pobreza e pela vulnerabilidade social. Esse tipo de configuração condiciona, ao menos em parte, o tipo de sociabilidade a que estão submetidos os moradores do território. Associado ao conceito de efeito vizinhança está o conceito de geografia das oportunidades, que comporta a ideia de que o território pode oferecer determinadas oportunidades objetivas a seus habitantes. A estas oportunidades objetivas os indivíduos respondem de acordo com um "filtro de percepção", formado a partir do tipo e a maneira pela qual foram socializados nesse mesmo território.

Isso significa que o território é duplamente importante. De um lado, o território oferece chances para que os indivíduos se desenvolvam (geografia objetiva de oportunidades). De outro lado, incide sobre o julgamento que esses mesmos indivíduos fazem da maneira em que podem ou não se beneficiar das chances de desenvolvimento postas diante de si, com uma margem para tomar suas próprias decisões e para fazer suas próprias escolhas (geografia subjetiva de oportunidades). 
Podemos acrescentar a isto que a relação dos indivíduos com suas famílias e o modo pelo qual foram apresentados ao mundo e socializados também tem relevância no modo como cada um interpreta as oportunidades que se colocam à sua frente. Levando em conta a pertinência destes conceitos para o nosso objeto de estudo, incluímos esses temas nas entrevistas com os profissionais da escola, os gestores do PEA/Bairro Educador e com as famílias, de modo a tentar captar como os mesmos percebem a Favela da Maré e o impacto da vizinhança no trabalho das escolas.

\subsection{3}

\section{As estruturas de oportunidades locais: a geografia das oportunidades}

Quando se pensa nos ativos que a Maré tem, é preciso destacar, em primeiro lugar, sua estrutura econômica. De acordo com o Censo de Empreendimentos da Maré, lançado pela instituição REDES da Maré (2010), o território possui cerca de três mil iniciativas econômicas, que vão desde pequenos negócios caseiros até mercados de médio porte, passando por bares, restaurantes, salões de beleza e serviços diversos.

A maior parte desses empreendimentos se concentra no setor do comércio, com mais de $66 \%$ das atividades econômicas, sendo a indústria o menor setor, com menos de $1 \%$. No total, esses empreendimentos empregam quase 9.500 pessoas, das quais 77\% são moradores da Maré. Esse quadro nos permite afirmar que o comércio interno na Maré gera uma renda considerável e é uma importante fonte de oportunidades de emprego, além de atender um mercado consumidor interessante do ponto de vista econômico.

Por outro lado, a Maré possui mais de cem instituições sociais, distribuídas entre igrejas, ONGs, escolas, museus, centros culturais, instituições esportivas e náuticas (existe um pequeno clube náutico em Ramos e algumas colônias de pescadores ainda ativas). Isso sem contar as inúmeras manifestações culturais que acontecem em espaços abertos como praças e ruas. Assim, é fácil constatar que há uma intensa vida econômica, associativa e comunitária que se coloca à disposição dos moradores podendo impactar positivamente em seu cotidiano. 
Um bom exemplo de uma iniciativa social local é o curso pré-vestibular da instituição Redes da Maré, fundada por um grupo de moradores locais. Esse projeto procura ajudar moradores da Maré, que completaram o ensino médio a ingressar em uma universidade.

Só essa iniciativa, ao longo de quase vinte anos, promoveu a entrada de pelo menos mil moradores da Maré em universidades públicas e na PUC-Rio, em cursos que tradicionalmente não recebem moradores de favelas, como é o caso de Direito e de Medicina. Podemos inferir que o aumento do número de universitários na Favela da Maré pode trazer alguns benefícios tanto para os indivíduos que ingressaram no ensino superior quanto para a comunidade. Desse modo, a Maré tem uma estrutura de oportunidades bastante razoável para um espaço popular. Essa estrutura de oportunidades, que forma a geografia das oportunidades local, passa, necessariamente, pelo filtro da percepção individual.

Voltando ao exemplo do curso pré-vestibular, não basta termos uma instituição que ofereça as vagas e que diga aos moradores que é interessante projetar a entrada em uma universidade e em um curso superior porque isso, de alguma maneira, pode vir a impactar positivamente em suas vidas. Esses moradores precisam acreditar que entrar em uma universidade fará sentido. E, antes disso, também precisam cumprir um pré-requisito básico: ter estendido sua escolaridade até o ensino médio, o que, por sua vez, significa ter estudado pelo menos durante doze ou treze anos.

No Brasil, pouco mais da metade dos estudantes completa o ensino médio, o que mostra a dificuldade da população brasileira para ascender, pelo menos, aos níveis intermediários de educação escolar. Por outro lado, quem trabalha e pesquisa sobre as favelas compreende o quanto é difícil a trajetória escolar de estudantes que moram nesses territórios (PEREGRINO, 2010). O cotidiano de interrupções das aulas por conta de greves de funcionários, conflitos armados entre grupos rivais que disputam o território, ou mesmo a falta de professores, torna incerta a continuidade e a qualidade das aulas.

Assim, permanecer na escola e concluir o ensino médio não é uma tarefa fácil para os meninos e meninas das favelas, sempre premidos pela necessidade de também arrumar um emprego para ajudar economicamente a família. Por essas razões, o tema da geografia das oportunidades foi contemplado nas entrevistas 
junto com o conceito de efeito vizinhança. Nesse sentido, perguntamos aos profissionais da escola, responsáveis e gestores do PEA/BE quais suas impressões acerca da influência do território e da vizinhança sobre a escola e sobre as trajetórias escolares dos alunos e que tipo de oportunidades acreditavam que a Maré poderia oferecer.

Quando perguntados sobre, por exemplo, as parcerias que, em nossa pesquisa, foram tomadas como um dos indicadores do que o território pode oferecer como oportunidade para a escola, uma das profissionais da Escola Branca apontou que elas existem e que não se limitam apenas às parcerias locais.

A maior parceria é com o Piscinão ${ }^{33}$ e o posto de saúde [...]. Esse ano, especificamente, a gente tá com um projeto com uma professora, não sei se da PUC [...]. É uma professora que veio o ano passado para visitar a escola e esse ano conseguiu um projeto pela FAPERJ. Não é sempre, mas são projetos que vão e vem. Até o ano passado [...], tinha um projeto com a Redes da Maré (Agente administrativo da Escola Branca).

Outra agente escolar confirma a importância da parceria com o Posto de Saúde e de outras parcerias para a Escola Branca. Segundo ela:

Na maioria das vezes, o posto [de saúde] sempre trabalha em conjunto com a gente. Quando a gente tem qualquer desconfiança de que a criança tem problema de saúde, ou de abuso ou de violência no lar comunicamos ao posto de saúde que sempre tenta, da melhor forma possivel, atender.Tem ainda o parque da vizinhança (Vila Olímpica). Estão sempre aqui, nesses dias mesmo eles trazem palhaços, tem o pessoal de educação física que vem três ou quatro vezes na semana [...]. Quando tem festa eles vêm aqui, convidam as crianças e levam até lá. A gente esse ano também tem parceria com o pessoal da UNIRIO que também é o pessoal que tem um projeto aqui na escola. Eles estão sempre aqui na escola [...], tem estagiárias delas aqui, com relação à leitura, trabalhando na sala de leitura das crianças. Isso proporcionou um passeio com as crianças lá no Museu do Rio. (Agente administrativo da Escola Branca)

Pelo que percebemos, a parceria entre a Escola Branca e o posto de saúde local - os prédios ficam lado a lado - funciona bastante bem. O que se pode questionar é se não seria o papel da escola, e não do posto de saúde, encaminhar os casos de abuso e violência contra as crianças ${ }^{34}$.

\footnotetext{
${ }^{33} \mathrm{O}$ "Piscinão" é um espaço de lazer administrado por uma OS (organização Social) localizada em uma das comunidades/favelas da Maré.

${ }^{34} \mathrm{~A}$ esse respeito tentamos conversar com os administradores do posto de saúde, uma Organização Social, porém não obtivemos sucesso.
} 
O fato, porém, é que a Escola Branca consegue articular parcerias locais, aproveitando o que algumas instituições do território poderiam oferecer, ao mesmo tempo em que conseguem firmar parcerias externas com universidades como a PUC-RIO e a UNIRIO ${ }^{35}$. Fica evidente, assim, que a escola e seus agentes levam em conta o que o território pode oferecer como oportunidades para ampliar as ações da escola e fortalecer determinadas áreas curriculares.

Quando interrogamos a Escola Azul sobre as parcerias, constatamos que elas não existem. Ao contrário da Escola Branca, a Escola Azul não tem parcerias locais ou externas. Esse fato chama a atenção porque a Escola Azul participa do PEA desde 2009e abrigou, até o ano de 2013, o Bairro Educador.Todavia, há, próximos à escola, um museu e um lona cultural, que têm como política a realização de parcerias com instituições locais, incluindo-se as demais escolas da Maré. Por isso, nesse contexto, esperávamos encontrar algum tipo de "cultura de parcerias" na Escola Azul, já que uma das propostas do PEA/BE era justamente a abertura das escolas a iniciativas de instituições e pessoas do território.

Essa proposta é corroborada pelos gestores do Bairro Educador nas falas sobre a experiência do Programa como comércio local, por exemplo:
A gente usou e abusou das parcerias com o comércio local. Nossa! No complexo da Maré e em Santa Cruz [...]nossa!Aí era uma brincadeira interessante porque eles [alunos] podiam mexer na balança, eles podiam escolher legumes. Tinha tudo, porque aí trabalha o que era legume, verdura, o que era condimento [...] pesagem, troco, [...] a gente fez plaquinha, a gente distribuiu diploma [para os comerciantes] (Gestorada ONG que cuidou do Bairro Educador).

Na sequência da entrevista, a mesma gestora conta a experiência vivenciada com as crianças de outra das escolas da Maré e com os professores que participaram do PEA/BE. A experiência se passa numa feira livre que acontece aos sábados numa das ruas mais importantes da Maré. Lá, alunos e professores interagiram com os vendedores locais. Nessa atividade, os alunos puderam mobilizar, segundo o depoimento da gestora, conhecimentos de geografia, ao planejarem o caminho até a feirae de matemática, ao comprarem frutas para uma

\footnotetext{
${ }^{35}$ Destacamos que não houve uma explicação clara sobre os mecanismos institucionais que envolvem os acordos - por exemplo, se há contrapartida da escola e qual a periodicidade das parcerias -, bem como são feitos os contatos com os potenciais parceiros. Isso nos leva a crer que o estabelecimento das parcerias pareceu ser mais uma demanda atendida a partir da ação de agentes externos do que uma ação deliberada da escola.
} 
atividade na escola que certamente envolveriam conhecimentos extracurriculares, tais como o preparo de alimentos, higiene, segurança, entre outros. Outras ações similares a essa estão registradas e podem ser encontradas no blog mantido pelo Bairro Educador ${ }^{36}$.

O que constatamos, no entanto, a partir das entrevistas e da observação de campo, é que os três anos de participação da Escola Azul no PEA/BE não foram suficientes para deixar uma marca ou um legado que sedimentasse a prática de interação com as instituições locais. Ao que parece, o tema das parcerias nessa escola também não tem uma dimensão tão relevante quanto na Escola Branca, que não participou do PEA/BE.

O que a nossa pesquisa evidencia é que, apesar das muitas limitações impostas pela desigualdade e pela má distribuição social de bens, serviços e direitos, o território da Maré pode oferecer a seus moradores e às escolas uma estrutura de oportunidades ou uma geografia de oportunidades que precisa ser considerada.

\subsection{4 \\ Eficácia normativa}

Nas favelas/comunidades onde se localizam a Escola Azul e a Escola Branca, há forte presença de grupos criminosos que dominam o território e se impõem a partir da violência armada. Esse é um drama vivido por grande parte das favelas cariocas e que se agravou nos últimos vinte anos. Basicamente, esses grupos se dividem entre os que comercializam drogas ilícitas, os narcotraficantes, ou, como são usualmente chamados nas favelas, os traficantes, e os que praticam outras formas de crimes não relacionadas ao tráfico de drogas, como é o caso dos grupos paramilitares, mais conhecidos como milícias ou milicianos.

Na Maré existem, segundo dados da Polícia Militar do Estado do Rio de Janeiro (PMERJ), três grupos ou facções criminosas que controlam o comércio de drogas ilícitas na favela. Embora incerta, a estimativa é que esses grupos arregimentem cerca de 200 homens cada um, ou seja, ao todo o "tráfico" possui 600 "soldados". Em termos percentuais, isso equivale a menos de 0,5\% dos mais

\footnotetext{
36 Disponível em: http://bairroeducador.blogspot.com.br/search/label/BE\%20Mar\%C3\%A9. Acesso em março de 2017
} 
de 136.000 moradores da Maré. Assim, a pergunta que se coloca é: como um percentual tão pequeno de pessoas consegue dominar tantas outras?

A resposta a esta pergunta está na força bélica das armas empunhadas pelos "soldados do tráfico" e o clima de violência que estes impõem. A rede de comércio de drogas que se cria nas favelas, gera lucros que atraem muitas pessoas. Há, de fato, um "mercado de trabalho" criado entorno das drogas ilícitas que atrai muitas pessoas, na maioria jovens, em busca de renda. Essas redes comerciais transbordam para outros espaços da cidade e abastecem a demanda que vêm, inclusive, de bairros "nobres".

Por outro lado, em territórios como a Maré, o Estado, desde o início, esteve ausente e, mesmo quando se fez presente, o fez de forma precária. Por isso, os grupos criminosos ocuparam o espaço e se estabeleceram como força, inclusive como força política, já que atuam não apenas no comércio de substâncias ilegais, mas exercem, também, funções que deveriam caber ao poder judiciário, à prefeitura e à polícia.

Até alguns anos atrás, com a quase total ausência de programas sociais e de garantia de direitos, alguns "chefes do tráfico", dentro e fora da Maré, desenvolviam ações "caridosas" junto às favelas/comunidades, tais como: socorrer os mais pobres e doentes. Outros promoviam festas, compravam brinquedos para as crianças em datas especiais e patrocinavam jogos de futebol com o objetivo claro de angariar a simpatia da população local e como uma forma de tentar "compensar" o mal feito às comunidades e de alguma maneira minorar os problemas causados.

Contudo, o que pudemos constatar, a partir de nossa pesquisa, e da experiência que adquirimos nos anos de trabalho e convivência com a realidade da Favela da Maré, é que essa relação vem mudando. O tráfico de drogas é um grande negócio e, como tal, está sujeito à lógica do lucro e da concorrência de mercado. O quadro hoje é bem mais grave porque os grupos rivais se enfrentam com o intuito de controlar a distribuição e venda de drogas nos distintos territórios. Fazem isso sem considerar a questão dos riscos que os constantes confrontos - potencializados pelo ao avanço exponencial do poder de fogo das armas usadas - acarretam para os moradores. 
Nesse contexto, cada vez mais pessoas que não estavam implicadas diretamente com a dinâmica das disputas dos grupos rivais e nem tomavam parte nos confrontos são assassinadas; mais moradores são atingidos pelos disparos das armas de fogo, mesmo estando a quilômetros de distância do lugar onde ocorrem os enfrentamentos.

No meio desse cenário, a polícia acaba sendo mais um fator complicador, pois suas ações, na maioria das vezes, acirram ainda mais o clima de medo, tensão e confrontos. Um dos resultados perversos desse estado de coisas é que as incursões policiais, somadas aos constantes confrontos entre grupos criminosos rivais, são a causa mais frequente do fechamento das escolas da Maré.

Além desses grupos criminosos e da ação da polícia, existe ainda a ação da chamada "milícia". Estes grupos são, em sua maioria, formados por policiais, expoliciais e bombeiros que dominam determinados territórios a partir da imposição de regras que fazem valer a partir da violência e da intimidação armada. Contudo, existem algumas diferenças com relação ao tráfico. A primeira é justamente a proibição da venda de drogas, pois não existem "bocas de fumo" ${ }^{37}$ nas áreas dominadas pelas milícias. Isso diminuiu substancialmente os confrontos armados, pois as disputas também diminuem, já que não há pontos de venda para serem disputados.

Esse fato pode dar a falsa impressão de nessas áreas as relações entre a milícia e a comunidade sejam mais tranquilas. Pelo contrário, assim como o tráfico, a milícia se organiza para explorar o território e as pessoas que moram nele. A preocupação maior, assim como nos territórios dominados pelos grupos de narcotraficantes, é lucrar. Como o tráfico, a milícia é um grande negócio, que explora as pessoas mais pobres e as submete a todo tipo de dominação.

Os "milicianos" exploram "serviços" como os sinais ilegais de TV à cabo, os transportes alternativos, a venda de botijão de gás, usado em todas as favelas cariocas, e cobram das pessoas e dos comerciantes "taxas de segurança". Esses grupos costumam ser altamente organizados e com ramificações na política parlamentar, ou seja, financiam campanhas políticas e elegem deputados e vereadores comprometidos com seus interesses. A prova desse fato foi a

\footnotetext{
${ }^{37}$ Locais onde são comercializadas as drogas ilícitas. São, no geral, fortemente guardadas e constantemente fonte de disputas armadas.
} 
Comissão Parlamentar de Inquérito (CPI) das milícias realizada pela câmara de deputados do Rio de Janeiro em 2008, que indiciou cerca de 226 pessoas e ajudou a desmontar uma organização poderosa na zona oeste da cidade, que incluía um vereador e um deputado estadual.

É preciso deixar claro que, diferentemente da percepção do senso comum, a maioria dos moradores das favelas não tem envolvimento com o tráfico de drogas ou com os grupos paramilitares. Existem, obviamente, redes de pessoas que integram e apoiam a logística operacional de tais grupos, mas a quantidade de pessoas envolvidas é ínfima perto da população que mora nesses territórios.

A distância que os moradores procuram manter desses grupos ficou bastante evidente ao longo de nossas entrevistas. Todas as vezes em que questionamos a relação das comunidades com os grupos criminosos, as respostas foram sempre no sentido de afirmar o perigo de tais grupos e dos males que a atuação destes causava para a vida de todos os moradores e para a escola.

O sentimento da maioria de nossos entrevistados é o de que para suas favelas/comunidades, filhos e escolas, os grupos criminosos são um risco que precisa ser contornado de alguma maneira. Nesse sentido, as pessoas desenvolveram práticas de convivência com o status quo, sem que isso, no entanto, signifique conivência e aceitação de uma situação que deveria ser enfrentada de forma séria e urgente pelo Estado e pela sociedade, pois escapa completamente da tentativa de soluções locais.

Não sem propósito, nas entrevistas que realizamos, a atuação desses grupos criminosos é apontada como uma das maiores preocupações de todas as pessoas que vivem ou que trabalham nas favelas/comunidades da Maré. Segundo os entrevistados, este é o fator que mais dificulta a vida no território. A imposição e a presença violenta desses grupos desestabilizam o cotidiano das pessoas e instituições locais e atrapalham todos os projetos de desenvolvimento local.

O quadro traçado acima mostra a complexidade do contexto em que atuam as escolas da Maré. Se, por um lado, existem ativos sociais e econômicos importantes na Maré e, por isso, ela não pode ser caracterizada apenas como um território de pobreza e violência, por outro lado, há de se levar em conta as dificuldades advindas da atuação dos grupos criminosos e sua interferência no cotidiano das pessoas e instituições.Diante deste cenário, as redes comunitárias e 
as instituições, como a escola pública, que deveriam garantir direitos e proteger às crianças na Maré, ficam fragilizadas.

Para entender um pouco mais a complexidade dessa realidade, utilizamos a categoria "eficácia normativa", que nos ajuda a compreender melhor o papel das escolas no contexto da Maré e a importância de sua aproximação com o território e com as famílias de seus alunos. De acordo com Flores (2008, p. 150), crianças que vivem em "comunidades onde as normas são claras, legitimas e ativamente vigiadas pelos seus habitantes, terão menos probabilidade de apresentarem comportamentos de risco". O contrário também é verdadeiro, crianças que vivem em comunidades onde as regras não são claras e onde não há coesão social suficiente para estabelecer parâmetros de vigilância e controle, os mais jovens tendem a ter mais problemas com comportamentos de risco social.

Quando colocamos essas questões para os entrevistados percebemos que a ideia de "vigiar" as crianças é uma das preocupações constantes. Numa das entrevistas, um dos profissionais da escola da Escola Azul, afirma que:

Tem pais que têm medo, o grande medo é o filho ficar na rua e se "misturar". Da mesma maneira que eles vigiam lá, aqui eles não podem vigiar [...] passam essa responsabilidade para mim, muitas vezes já ouvi de mãe e pai: por favor, fica de olho, presta atenção. Tinha pai que obrigava o aluno a me dar bom dia porque tinha uma escola com 1.500 alunos e eu não sabia quem eram os alunos e o pai obrigava e me dar bom dia porque aí depois me ligavam para saber se o aluno tinha ido à escola naquele dia (Agente administrativo da Escola Azul).

É importante reconhecer que muitas famílias procuram na escola uma parceria para cuidar de seus filhos e mantê-los afastados das condutas de risco. A rua, em contraponto, representa o perigo. É isso o que diz um dos familiares, cujo filho estuda na Escola Azul, ao ser perguntado sobre as atividades que o filho realiza quando não está na escola: "Aqui também tem a Vila Olímpica, ele faz natação. Procuro sempre ocupar o tempo dele porque se deixar na rua, se mistura com quem não deve, ainda mais aqui onde eu moro"(Mãe da Escola Azul).

$\mathrm{O}$ interessante deste depoimento é que mobiliza dois conceitos com os quais vimos trabalhando: a geografia das oportunidades e a eficácia normativa. O responsável, preocupado em afastar o filho dos riscos da rua e da "mistura com quem não deve", identifica no território oportunidades de desenvolvimento de práticas que garantam segurança e mobilizam novas sociabilidades. A partir daí, 
toma a decisão de investir em outras atividades que não apenas àquelas ligadas diretamente à escolarização, mas que dizem respeito ao processo de socialização das crianças no território.

Ainda de acordo com a preocupação de se evitar os riscos da rua e da "mistura" que ela oferece, as famílias desenvolveram outras práticas, sendo uma das mais comuns a alternância com vizinhos na hora de levar e apanhar as crianças nas escolas, sobretudo, as menores.

Durante as observações feitas nos horários de entrada e saída das Escola Azul e da Escola Branca, constatamos que grupos de crianças eram conduzidos por um adulto, geralmente, uma mulher, que mais tarde identificamos como sendo uma "vizinha" dessas crianças. Isso exige um bom grau de conhecimento, compartilhamento de valores e confiança entre os responsáveis pelas crianças e seus vizinhos.

Não temos dúvidas de que essa rede de proteção entre vizinhos é uma busca deliberada pela manutenção de ações que podem ser definidas a partir do conceito de eficácia normativa. Os moradores procuram fazer frente ao cenário de adversidade formado pelas redes criminosas que, em muitos momentos, são concorrentes e sempre desestruturantes.

Assim, a criação dessas redes de proteção tem como objetivo preservar o poder da comunidade para manter suas crianças afastadas dos comportamentos de risco. Elas mobilizam o que Flores chamou de eficácia coletiva, que diz respeito à orientação normativa do coletivo para metas como disciplina e respeito e o conhecimento intergeracional.

Atitudes como essas precisam ser valorizadas e mesmo estimuladas pelas escolas que atuam em territórios onde existe concentração de pobreza e que sofrem com a violência, como é o caso da Maré. Isso porque o comportamento das crianças também é fortemente marcado pelos processos sociais que se inscrevem nas práticas territoriais e pelas redes de influência que se criam nele.

Ligado a essa questão está o modo pelo qual as informações e modelos de comportamento circulam e ajudam a definir, em grande parte, o comportamento dos indivíduos mais jovens nas favelas/comunidades. 


\subsection{5}

\section{As fontes de informações}

De acordo com Flores (2008), um dos mecanismos mais importantes no que diz respeito à socialização das crianças nos bairros pobres está relacionado às fontes de informação presentes no território. Isso significa que "um indivíduo adapta e utiliza informação relevante em seu contexto como guia de comportamento" (FLORES, 2008, p. 150). Na sequência, a autora afirma que a informação disponível tanto "fomenta comportamentos funcionais (disciplina), como desviados (indisciplina)".

Assim, atitudes como:a evasão escolar e condutas criminosas, quando concentrados em determinados territórios, sobretudo, nos mais pobres, podem se espalhar entre as crianças e jovens, o que foi denominado por Flores de contágio ou "difusão de comportamento" (ibidem, p. 152).

De modo complementar, a mesma autora desenvolve o conceito de "influência do semelhante", definindo-o como uma das mais importantes fontes de informação presentes no território. De acordo com esse conceito, o acesso a redes comunitárias, pessoas e instituições locais leva as crianças a construírem seu próprio repertório comportamental a partir do "espelhamento" de grupos e indivíduos com os quais convive.

Por isso, quando abordamos nas entrevistas o tema da eficácia normativa, pudemos perceber que os responsáveis pelos alunos se preocupam bastante com a influência das redes criminosas que ocupam a "rua" tornando-a tão perigosa. Nesse sentido, o perigo não se resume apenas à ameaça dos confrontos armados, mas também ao risco de cooptação através da influência e do contágio da figura do traficante sobre as crianças, principalmente as maiores. Para alguns familiares entrevistados, esse mostrou ser o principal motivo de preocupação.

Outro conceito mobilizado por Flores e que nos ajuda a pensar o processo de socialização das crianças da Maré e sua relação com as escolas e com a escolarização é o "modelo de papel social". De acordo com ele, as altas taxas de desemprego ou a relação precária com o mundo do trabalho vivida por boa parte dos indivíduos que moram em territórios pobres dificultam o estabelecimento de relações positivas e de exemplos concretos que possam ser seguidos pelos mais jovens. 
A escassez de modelos de sucesso no mundo do trabalho, por exemplo, retira a chance dos mais jovens conhecerem melhor o funcionamento $\mathrm{e}$ as qualidades que o mercado exige para uma carreira de sucesso. Retira a possibilidade, acrescentamos, de que a escola seja vista como uma das etapas fundamentais para que as qualificações para o trabalho sejam consolidadas.

Falamos em outro ponto da iniciativa de um pré-vestibular comunitário realizado por uma das instituições da Maré. Vimos que, para chegar a esse estágio, os alunos, necessariamente, deveriam permanecer na escola e concluir o ensino médio, o que não é tarefa tão simples. Se observamos esse dado sob a ótica do conceito de modelo de papel social, percebemos o quanto é difícil para as crianças da Maré projetarem uma trajetória escolar mais longa e ter um modelo positivo para seguir em termos de escolaridade e trabalho.

A Maré tem uma das taxas mais altas de analfabetos da cidade e uma das menores taxas de universitários. Assim, é muito mais fácil para um menino ou uma menina da Maré ter em casa, ou próximo de si, alguém que é analfabeto do que alguém que é universitário. Esses fatos tornam escassos os exemplos de sucesso escolar e profissional a serem seguidos pelas crianças e gera um círculo perverso que se autoperpetua.

Por isso, para nós, a escola tem papel preponderante na formação de modelos positivos de papel social que possam ser seguidos pelas crianças.A escola é a condição básica para a maioria das profissões e para profissionais de sucesso, pois habilita e distribui os títulos escolares para que os indivíduos preencham determinadas ocupações socioprofissionais mais valorizadas (BOURDIEU, 2008).

Embora não se trate de processos lineares, é razoável supor que a elevação do nível de escolaridade, o que remete ao aumento do tempo de permanência na escola e ao sucesso escolar, dos moradores da Maré, pode colaborar para o aumento da quantidade de indivíduos a ocupar postos de trabalho mais qualificados. Esse fato, por sua vez, pode ter repercussões positivas também para a multiplicação de "modelos de sucesso" a serem seguidos pelos mais jovens.Em razão disso, indagamos nas entrevistas como os profissionais das escolas projetavam o futuro escolar de seus alunos e, complementarmente, como os responsáveis pelos alunos viam essa questão. 
Procuramos comparar as respostas dos entrevistados das Escolas Azul e a Escola Branca, de modo a verificar se, na percepção dos mesmos, existiriam diferenças que pudessem ser atribuídas ao fato de a unidade escolar ter participado ou não do PEA/BE. Na entrevista com uma das professoras da Escola Azul, indagamos qual o nível mais alto de estudos que ela acreditava que seus alunos alcançariam.

Os meus alunos, muitos vão para a faculdade porque eles são muito espertos [...] e eles vão longe, tenho certeza. Bom, todos não, mas uma grande parte, acho que dos meus 35, pelo interesse e pelo desenvolvimento deles, eu creio que uns 20 alunos vão chegar na faculdade e vão terminar. Desejo que todos chegassem, mas não vai ser assim, não (Professora da Escola Azul).

A mesma pergunta foi colocada na entrevista com outra professora da mesma escola.

Explico pra eles [alunos] que, infelizmente, o ensino público está aquém da capacidade deles. Eles têm um potencial muito maior, poderiam render muito mais [...] com o ensino que eles têm quase todos podem atingir esse objetivo[níveis mais altos], mas com qualidade, são pouquíssimos. Eu diria que dos 32, tenho cinco com qualidade. No ensino médio, acho que quase todos chegam [...]. Na faculdade acredito que só uma minoria chega. Embora, quando perguntei para eles quais são os planos, eles se colocam no nível superior, como veterinário, médico, advogado, psicólogo; mas eu acredito que nem todos vão atingir esse objetivo, não (Professora da Escola Azul).

Essa mesma pergunta foi respondida por um dos professores da Escola Branca, nos seguintes termos:

Vou te falar, é triste, mas não é muito promissor, não. A falta de recursos financeiros da família, falta de recuso financeiro, apesar de ter isso nas classes mais altas. Mas vou ser um pouco capitalista, sim, vou pelo financeiro. Porque se você tem condição, você tem mais oportunidade e você chega a objetivos mais distantes. Agora eu fico muito triste de falar isso, de eu não poder puxar mais gente (Professor da Escola Branca).

Também na Escola Branca, outra professora deu a seguinte resposta:

Eu não tenho muita esperança de que eles vão fazer uma faculdade. Tenho ex-alunos, acho que metade fez ensino médio, muitos menos começaram a faculdade e eu vejo tantos outros por aí, lavando carro, carregando mesa [...] acho que eles não têm expectativas de sair daqui, procurar coisa melhor, são muito fechados aqui na comunidade. (Professora da Escola Branca) 

ela:

Dirigimos essa pergunta também a uma das mães da Escola Azul. Segundo

Se depender de mim, eles vão estudar até a faculdade. Acredito que os professores da escola também acreditam. Porque os meus filhos não dão trabalho. Ele[filho] fala que quer fazer faculdade de educação física (Mãe de aluno da Escola Azul).

Quando indagamos uma das mães da Escola Branca sobre o nível mais alto de estudos que ela acreditava que seus filhos alcançariam, ela diz:

Espero que eles vão além, né? Possam fazer uma faculdade [...] porque hoje em dia é importante por causa o trabalho e para tudo [...]. Acredito que os professores da escola também pensam assim (Mãe de aluno da Escola Branca).

Alguns pontos dos depoimentos acima chamam a atenção. Em primeiro lugar, deve-se ressaltar que todos os entrevistados citaram o nível superior como o mais alto grau de estudos, ou seja, chegar a uma universidade é o mais longe que se pode ir.A esse consenso se soma um outro, no entanto,menos positivo: existiriam muitas dificuldades interpostas no caminho das crianças para que elas almejem o ensino superior. Alguns profissionais da escola culpam a família dos estudantes e sua "falta de expectativas", outros culpam o território, a falta de recursos econômicos, o isolamento nas comunidades e, de maneira não declarada, a maioria deixa transparecer que as crianças não possuem as aptidões necessárias para chegar ao ensino superior.

Outra questão relevante a ser observada se refere ao fato de nenhum dos professores/as entrevistados ter problematizado o papel da escola ou seu próprio papel na trajetória escolar e no sucesso ou fracasso dos estudantes. Parece que a ampliação das expectativas sobre o futuro acadêmico dos alunos e o trabalho em prol do aumento da escolaridade e de uma trajetória de sucesso das crianças da Maré, contraditoriamente, não foi visto como uma atribuição da escola.O que pudemos encontrar, assim, foi que praticamente não há diferenças quanto às expectativas que os profissionais das duas escolas pesquisadas projetam sobre os alunos, seja em termos de sucesso escolar, seja de possíveis trajetórias escolares de longa duração.

Por outro lado, os responsáveis alimentam expectativas de que seus filhos e filhas possam atingir níveis mais altos de escolaridade. Percebemos que o desejo é de que a geração jovem possa ir mais longe do que eles próprios em termos escolares. Isso, como mostram vários estudos e também como pudemos 
comprovar em nossas observações de campo, é muito comum, pois os responsáveis, embora não conheçam tão bem os mecanismos e a dinâmica das instituições de ensino superior, acreditam que elas podem oferecer oportunidades e benefícios para seus filhos e filhas.

Chama a atenção, ainda, o fato de os responsáveis acreditarem que os professores e professoras também confiam que seus alunos possam chegar ao ensino superior. No entanto, as entrevistas mostram que isso nem sempre é assim e que há, portanto, um descompasso entre escolas e famílias quanto ao futuro acadêmico dos alunos.

\section{5}

\section{O Efeito Vizinhança}

O conceito de efeito-vizinhança refere-se ao fato de que a pobreza concentrada em determinados territórios impacta na cultura local, nas redes sociais internas, nos processos de socialização, nas oportunidades oferecidas localmente e nas decisões que cada indivíduo ou grupo de indivíduos toma.

Programas como o PEA/BE, que têm como premissa levar em conta o contexto territorial e o impacto que ele pode ter sobre a escola, a escolarização e as relações com as famílias, nos interessam porque permitem discutir o tipo de relação que as escolas da Favela da Maré desenvolvem com seus alunos, as famílias e a vizinhança.

Para nós, a qualidade e a intensidade do relacionamento estabelecido entre escolas e famílias podem impactar na vida escolar dos estudantes e ajudar a definir que tipo de oportunidades eles poderão ou não aproveitar ao longo da vida.Por isso, perguntamos aos nossos entrevistados sobre a avaliação que faziam a respeito da influência que a vizinhança e o território poderiam ou não exercer no trabalho escolar.

Quando indagamos junto a um membro da equipe de direção da Escola Azul sobre a relação de sua escola com a vizinhança, ela afirmou:

Eu tenho uma comunidade que me acolheu muito bem, todo mundo, toda a comunidade! [...] Inclusive o nosso "entorno". Tudo o que eu peço: não faz assim, não fica aqui... Nunca tive problemas [...], não consigo ver menos possibilidade do meu aluno da Maré. Sabe quando eu consigo ver menos possibilidade? Quando a gente não consegue dar aula [...]. 
Fora isso, a nossa concorrência com o "mundo lá fora" é totalmente leal... (Direção da Escola Azul)

Observamos nesse depoimento duas questões relevantes. A primeira diz respeito à importância atribuída ao acolhimento que a comunidade próxima à escola oferece aos profissionais de educação. Esse acolhimento parece transmitir segurança e respaldo ao trabalho escolar. A segunda observação é ade que há uma conotação peculiar dada para o conceito de "entorno". Não temos dúvida que esse "entorno" - quando das passagens: "pedi para não ficar á" e "nunca tive problema", pode ser identificado com o "pessoal do tráfico de drogas", como podemos confirmar ao longo da entrevista.

Obviamente, como esse é um tema extremamente delicado, a maioria dos entrevistados usou metáforas e subterfúgios para falar sobre ele. A fala acima não é exceção à regra. Na verdade, a maioria de nossos entrevistados, mesmo sob a garantia do anonimato, ficou preocupada e falou com cuidado sobre o tema do tráfico de drogas e grupos armados que atuam na Maré38.

É importante afirmar que essa não é uma situação exclusiva da Escola Azul, nem das outras escolas localizadas na Maré, já que a proximidade física com o tráfico de drogas é um dos temas sempre presentes em estudos e pesquisas que tratam de escolas localizadas em favelas (PAIVA; BURGOS, 2009).

A relação escola-favela quase sempre é tensa e marcada pela tentativa das escolas de impor limites à presença de pessoas ligadas à atividade do tráfico em seu espaço ou nas proximidades de seu prédio. Constatamos que a existência da proximidade física entre o tráfico e a Escola Azul era acompanhada, na rua da escola, por barreiras e postos de observação ocupados por jovens ligados ao tráfico, algumas vezes armados e outras com aparelhos de comunicação. Não verificamos, no entanto, a presença de pessoas ligadas aos grupos criminosos no interior da escola.

Confirma esta percepção o fato de a maioria dos entrevistados afirmar que a vizinhança escolar é boa, mas que a presença dos grupos criminosos, cuja principal atividade é o tráfico de drogas, é ruim e prejudica o trabalho escolar de

\footnotetext{
${ }^{38}$ Em algumas entrevistas as pessoas baixavam o tom de voz para falar dos grupos criminosos mesmo sabendo que ninguém poderia ouvi-las ou que o gravador captaria o áudio e registraria a fala do mesmo jeito.
} 
várias maneiras, sendo a principal os conflitos armados entre grupos rivais e com a polícia militar.

Professora da Escola Azul, quando indagada se, e de que maneira, a vizinhança e o que acontece nela, interferiam no seu trabalho, respondeu:

\begin{abstract}
Vou ser bem sincera, no começo eu não entendia como as coisas aconteciam, ultimamente tenho relevado mais. Por quê? Porque eu fico imaginando minhas crianças, elas ficam muitas vezes sem dormir, eu sei porque muitas vezes elas ficam no "zap": nossa "tá dando tiro". Isso já tarde da noite. Ficam sem dormir naquela expectativa, naquela ansiedade. Ali [...], como é que eu posso também querer um comportamento próprio ou adequado dentro de uma escola se eles não têm esse preparo, passaram a noite acordados, foram dormir tarde [...] não é uma coisa tranquila. Baseado nisso eu tenho pensado no aluno, no conjunto, na vida que ele leva no sofrimento [...]. Eu já não cobro, cobro, mas não assim... [...] A realidade deles é totalmente diferente e aí não é justo cobrar perfeição ou um comportamento adequado se não é isso que eles têm todo dia (Professora da Escola Azul).
\end{abstract}

Desse modo, a questão da violência no território e na vizinhança escolar teve impacto no olhar e nas relações que a professora construiu ao longo do tempo na convivência com seus alunos. Criou-se, a partir dela, uma representação negativa, embora carregada de preocupação com as crianças, acerca dos alunos, de seu mundo e da vizinhança. Essa representação identifica a vida na favela com um sofrimento, desconsiderando outras possibilidades oferecidas pelo território.

Quando indagamos um dos responsáveis de aluno da Escola Azul sobre a mesma questão, ele afirmou o seguinte.

A violência atrapalha muito. Semana passada mesmo, ela[aluna] só teve um dia de aula, só um dia mesmo. Não teve condições de dar aula, não. Ela perdeu a semana toda, perdeu mesmo (Avó de uma aluna da Escola Azul).

Esse depoimento revela que outra dimensão importante da violência é a paralisação das atividades escolares. Quando os conflitos armados se iniciam, forçosamente as atividades na favela ficam suspensas, pois a prioridade dos moradores e agentes públicos, como escolas, postos de saúde e outros serviços, é proteger a própria vida e a das pessoas com as quais trabalham e atendem.

Um dos fatos que mais nos chamou a atenção quando indagamos aos entrevistados sobre como a violência afetava suas vidas e, em especial, a rotina escolar foi o depoimento de uma integrante da equipe de coordenação da Escola 
Azul. A entrevistada nos disse que, dentro dos prédios escolares, também são adotadas práticas para garantir a integridade de alunos e profissionais da escola.

Uma das maneiras de proteger as crianças e professores quando os confrontos se iniciam envolve a pesquisa de locais dentro do prédio escolar que possam ser seguros e servir de abrigo provisório.

Eu chamei uma pessoa, um amigo, e ele veio aqui e me
mostrou, nas salas de aula, quais eram os "lugares cegos"
[onde os tiros não chegariam] para que as pessoas não viessem
para o corredor porque era deprimente ver aquelas pessoas
todas deitadas no chão do corredor, um monte de criança
gritando, chorando. É muito mais fácil se o professor controlar
o seu aluno no cantinho da sua sala. (Diretora da Escola Azul).

Essa é uma das medidas de proteção adotada também pelos moradores. Quase todas as casas na Maré têm também o seu "lugar cego", onde os moradores se abrigam quando há tiroteio. Esse é um ponto importante. Apesar de as 155 Escolas do Amanhã estarem localizadas em territórios tidos como "conflagrados", não há uma orientação clara, por parte das Coordenadorias de Educação e nem da SME-RJ, a respeito de como essas escolas deveriam lidar com os problemas de violência local.

Obviamente não esperávamos encontrar um "manual" sobre como agir em situação de risco, mesmo porque os contextos são bastante diversos para se ter uma orientação única, mas o que chama a atenção é o fato de o problema da violência armada não ser objeto de consideração por parte dos órgãos responsáveis pela implementação das políticas públicas educacionais.

$\mathrm{Na}$ verdade, o que percebemos a partir dos depoimentos das equipes de coordenação e execução do PEA/BE é que essa questão passou ao largo, como se nada pudesse ser feito. Causa, no mínimo estranhamento, que a Prefeitura nunca tenha emitido ao menos uma "nota" sobre as constantes paralisações das aulas em função dos tiroteios. Nem mesmo o sindicato dos professores, apesar de haver professores associados nas escolas da Favela da Maré, não emitiu nota a respeito da violência que afeta alunos e professores ou fez qualquer manifestação pública a esse respeito.

Como decorrência, cada escola a sua maneira, como fez a Escola Azul, encontrou a sua maneira de lidar com a violência gerada pelos confrontos armados. Na maioria das vezes, os estabelecimentos de ensino fecham suas portas 
diante dos conflitos ou diante da possibilidade do conflito, o que, em alguns momentos, pode significar muitos dias sem aula.

Levantamento feito por uma ONG local ${ }^{39}$, a partir de dados da própria SMERJ, constatou que, em 2016, as aulas foram paralisadas durante mais de vinte dias letivos, atingindo de modo diferente cada um dos estabelecimentos de ensino na Maré. Esse é um prejuízo irrecuperável para os alunos, pois apesar de formalmente haver um compromisso com a reposição das aulas por parte das escolas, na prática, isso não acontece ou ocorre de modo parcial e fragmentado.

Perguntamos aos profissionais da escola e aos responsáveis pelos alunos o que eles pensavam a respeito das relações entre as escolas e a vizinhança. $\mathrm{Na}$ Escola Branca, a maioria disse que as relações com a vizinhança eram boas e que, de modo geral, a comunidade acolhia bem a escola. A respeito da relação da escola com a comunidade, uma das profissionais da escola da Escola Branca assim se manifestou:

Não vejo nada que interfira. O que interfere é quando você é obrigado a mudar o que você tá pensando em fazer por causa de outras pessoas. E não vejo isso. A gente tem muito pouco problema com a comunidade. Graças a Deus a comunidade aceita a gente muito bem (professora da Escola Branca).

Fizemos a mesma pergunta para uma das responsáveis que avaliou a interação da comunidade com a escola da seguinte forma:

[...] é boa, um povo humilde, prestativo, se precisar de ajudar, táali. Eu acho que ajuda a escola (mãe de aluno da Escola Branca).

Perguntada sobre os possíveis impactos da vizinhança e do território no trabalho da escola, uma das professoras da Escola Branca respondeu:

Teve uma época que tinham muita violência aqui na comunidade. Isso desestabilizava professores e alunos também. Graças a Deus que já tem bastante tempo que não tem tido aqui [...] com certeza a violência tirava a gente do rumo. Por mais que a gente quisesse manter a calma, até um dia de calma era tenso (Professora da Escola Branca).

E uma agente administrativa da mesma escola completa:

Quando eu vim para cá não peguei a parte que a comunidade era tráfico de drogas, então o que eu sei, o que eu escuto falar, e que sei que marcou muito a vida das pessoas nessa época era a violência. Quando eu vimpara cá, aqui já era a atuação da

${ }^{39}$ Levantamento feito pela REDES de Desenvolvimento da Maré. 
milícia. Então eu não peguei nenhum caso assim que me marcasse tanto. (Agente administrativa Escola Branca)

É interessante observar que, assim como na Escola Azul, os profissionais da Escola Brancaconsideram que as comunidades/favelas acolhem bem a escola, mas que existe uma interferência negativa no trabalho com as crianças quando há violência.

No entanto, é preciso fazer duas observações. A primeira é a de que o contato com a vizinhança escolar, nas duas escolas, nos pareceu bastante limitado. Se considerarmos as parcerias locais, por exemplo, constatamos que elas não existem na Escola Azul. Na Escola Branca, essas parcerias são fruto muito mais de demandas externas do que uma política deliberada de abertura da escola. Mesmo na Escola Branca, os depoimentos se restringem a afirmar apenas que a relação com a vizinhança não interfere no trabalho da escola, como se nada mais fosse possível ou desejável nessa relação.

A segunda observação é que o tema mais relevante e presente na maioria das entrevistas foi o da violência armada dos grupos criminosos, tida como responsável por quase todas as questões que dizem respeito ao impacto da vizinhança sobre o trabalho escolar.

Vale ressaltar que a violência de que se fala aqui se resume aos grupos criminosos. Não houve, durante as entrevistas, referências a outros tipos de violência, como, por exemplo, a doméstica e a que ocorre no interior das escolas. Isso, de alguma maneira, oblitera outras questões importantes, que também são formas de violência, tais como a interrupção das aulas, a falta de atendimento adequado nos postos de saúde, a violência doméstica, entre outras.

Há, no entanto, uma diferença na percepção dos profissionais das Escolas Azul e Branca no que concerne à violência armada. Os profissionais da Escola Branca se sentem mais seguros na comunidade/favela, o que, sem dúvidas, se deve ao menor número de conflitos armados no local. Os depoimentos da professora e da agente administrativa indicam essa percepção. Como dissemos em outro ponto, a comunidade/favela onde se localiza a Escola Branca não tem a presença do narcotráfico. Esse território é ocupado pela presença de um grupo paramilitar, a milícia, o que explica a sensação de maior tranquilidade pela menor possibilidade de haver conflitos armados próximo à escola. 
Obviamente, isso não significa que, de fato, exista uma situação de tranquilidade, pois a milícia não tem o objetivo de ajudar a desenvolver ou de proteger a comunidade. Em nossas visitas à escola percebemos a presença de homens que "vigiavam" as ruas e que, embora não ostentassem armas de fogo aparentes, impunham, com sua presença os limites determinados pelo grupo criminoso do qual faziam parte.

Chama a atenção ainda o fato de que a questão de a pobreza não ter sido comentada como um dos possíveis fatores que impactam e dificultam as relações entre escolas e a vizinhança. É verdade que, ao longo de nossas entrevistas, a pobreza aparece nos depoimentos, mas não de maneira recorrente. Não houve uma referência mais contundente ou mais aprofundada à pobreza como causa das dificuldades enfrentadas no trabalho escolar.

O fato de que o tema da pobreza presente no cotidiano das favelas não tenha aparecido nos depoimentos dos profissionais da escola nos chamou a atenção, essa ausência vai de encontro à literatura especializada (FLORES, 2008), que aponta a pobreza como um dos fatores de maior impacto sobre o território, o trabalho escolar e o aproveitamento das oportunidades geradas para os indivíduos.

Nossa hipótese para a ausência de um debate mais enfático sobre o fator pobreza como um problema na relação escola-vizinhança é a de que a escola e seus agentes naturalizaram as condições de vida da população local, a ponto de não reconhecerem a pobreza como problema social mais abrangente, tomando-o como uma questão de cunho individual. Essa representação dos problemas enfrentados no território é fundamental para compreendermos a outra parte da relação escola-família-vizinhança.

\section{6}

\section{A importância da relação escola-família-vizinhança}

Embora os mecanismos pelos quais as relações de reciprocidade e influência mútua entre escolas-família-vizinhança não estejam completamente elucidados, acreditamos que podemos apontar alguns momentos onde é nítida essa simbiose.

$\mathrm{Na}$ escola, por exemplo, essa influência se traduz, na maior ou menor abertura à comunidade exterior, na maior ou menor crença nas possibilidades de sucesso escolar dos alunos e na maior ou menor interação com parceiros locais. 
Por óbvio, tais processos não se dão de maneira automática e da mesma forma em todas as escolas. No entanto, podemos afirmar com certa segurança que, quanto melhor for a relação da escola com as famílias e quanto mais ela está integrada à vizinhança e ao território onde atua, mais chances existem de fazer um trabalho de melhor qualidade.

Isso, por sua vez, pode ser traduzido, para os alunos e suas famílias, em termos de melhor desempenho escolar e na garantia de trajetórias escolares mais longas, com a diminuição da evasão escolar e a continuidade dos estudos para os níveis intermediário e superior.

Por outro lado, para a vizinhança, a escola pode ser reconhecida como uma instituição capaz de incidir sobre o desenvolvimento local ao elevar os níveis escolares da população e garantir mais oportunidades de sucesso no mercado profissional, por exemplo. A escola, assim, é vista como uma instituição central e que precisa ser protegida pela população.

Mas, é preciso reconhecer que esse não é um desafio fácil. Existem muitas questões que se colocam no caminho de uma relação mais produtiva entre escolasfamílias-vizinhança, como, por exemplo: de que maneira a escola pode estar integrada à vizinhança e ao território sem se deixar "colonizar" por ele? Ou seja, como, em ambientes de pobreza e de fracas referências normativas sociais a escola pode ao mesmo tempo se resguardar de uma "contaminação" das práticas desreguladoras da rua - indisciplina, violência - e ser a garantia do estabelecimento de normas que sustentem o aprendizado sem que isso crie uma barreira que a isole?

Não temos dúvida, que o primeiro passo para responder às questões acima éo estabelecimento de uma relação de proximidade e confiança entre escolas, famílias e vizinhança. Isso exige, certamente, abertura. Abertura para receber críticas, sugestões e para o engajamento na busca de soluções dos conflitos e problemas cotidianos por parte, principalmente, dos profissionais da escola e dos formuladores das propostas e políticas educacionais.

Uma relação de confiança cria para a escola e a seus profissionais o ambiente propício para dialogar com as comunidades/favelas e com as famílias em termos mais democráticos, mais abertos e favoráveis a acordos em prol de uma educação escolar melhor. 
Mas, reconhecemos, esse talvez seja o movimento mais difícil de ser feito pela escola dada a sua cultura e sua forma de funcionamento, ainda marcadas pelo viés centralizador e hierárquico.

\section{7 \\ Antinomia/relações armadilhadas}

Como dito em outro momento, no caminho das boas relações e das relações mais produtivas entre a escola e seu público se colocam muitas "armadilhas" (SILVA, 2003), que precisam ser reconhecidas como tais e, a partir daí "evitadas" ou "desarmadilhadas".

Uma das mais armadilhas mais comuns é a do "pigmaleão". De maneira bem objetiva: isso quer dizer que os professores projetam determinadas expectativas em relação ao comportamento dos responsáveis pelos alunos e estes, por sua vez, passam a se portar de acordo com tais expectativas. Esse processo também reflete nos alunos que, por sua vez, se espelham nas expectativas de professores e de seus responsáveis.

Desse modo, a imagem do "bom" ou o "mau" pai/responsável tem muito mais a ver com o que a escola define como verdade a ser seguida do que com a realidade das famílias. Por outro lado, as armadilhas têm a ver também com as relações antinômicas estabelecidas entre essas escolas e famílias, tendo como componente inseparável, o território.

$\mathrm{Na}$ verdade, como pudemos discutir neste trabalho, diversos estudos apontam para o fato de que as práticas socializadoras das crianças realizadas pela escola de um lado e pelas famílias de outro, são antinômicas (THIN, 2006). Essa situação gera uma série de desencontros que precisam ser observados com cuidado por todos os agentes sociais envolvidos no processo de educação, em especial, àqueles das crianças dos meios populares.

Nesse sentido, quando realizamos a pesquisa, nossas observações de campo e as entrevistas caminharam no sentido de tentar entender como se processavam as relações entre escolas-famílias-vizinhança na Maré à luz dos conceitos de relações armadilhadas e relações antinômicas.

Também queríamos compreender se a escola que integra o PEA/BE conseguiu desenvolver práticas diferentes da escola que não participa do 
Programa. Isso pode ajudar a pensar ou repensar políticas públicas no campo da educação para espaços como a Maré.

\section{8}

\section{Encontros entre escola-família: um dia de reunião}

Uma de nossas preocupações foi justamente a de registrar os momentos de encontro entre os profissionais da escola e as famílias. Nossa intenção era avaliar como eles interagiam, se comunicavam, cooperavam e resolviam seus conflitos coletivamente. Contudo, no período em que visitamos as escolas esses encontros não foram tão frequentes e se concentraram nas reuniões mensais obrigatórias do Programa Bolsa Família e Cartão Carioca.

Nossa intenção, neste momento, foi observar uma reunião entre profissionais da escola e responsáveis. Analisaremos, inicialmente, a reunião ocorrida em um sábado pela manhã na Escola Azul, onde a equipe de direção reuniu os responsáveis pelos alunos, em sua maioria beneficiários de programas de renda mínima. Essa reunião nos forneceu algumas pistas significativas acerca das relações entre a escola e as famílias.

Assim, a primeira questão que nos chamou a atenção foi a recepção da escola para com as pessoas que chegavam para a reunião. Isso porque nos pareceu que houve descuido com a preparação da escola no que se refere ao acolhimento dos responsáveis pelos alunos e na criação de um ambiente favorável. Por exemplo, a reunião foi marcada para as 9horas da manhã, mas não havia café ou água para as pessoas que chegavam. É claro que a escola não tem a obrigação de disponibilizar esses serviços, mas poderia ser interessante um gesto nesse sentido. A chegada da família na escola é sempre um momento importante e seria, acreditamos, uma boa oportunidade para uma recepção mais calorosa. As pessoas poderiam se sentir mais bem acolhidas.

A reunião foi realizada no refeitório da escola, único local grande o suficiente para acomodar as sessenta pessoas que compareceram. Fato curioso é que só havia três homens, prova de que, ao menos nessa escola, o acompanhamento das reuniões com a escola é feito pelas mulheres. Entre os assuntos que ganharam destaque, esteve o comportamento dos alunos. 
A diretora mencionou quea indisciplina era uma reclamação constante dos professores e professoras e que os pais e mães deveriam ficar atentos para o comportamento de seus filhos e filhas. Ela claramente convocava a "casa" para ajudar a escola na disciplina das crianças.

É interessante marcar aqui que o tema da disciplina/indisciplina foi um dos mais comentados durante as entrevistas que fizemos com os professores. Por exemplo, ao falar sobre esse assunto, uma das pessoas que compõem a equipe de direção nos disse que o maior desafio na escola atualmente é:

[...] lidar com o limite, ou aliás a falta de limite e a indisciplina do aluno porque perdeu-se o respeito pela escola, pelos professores e pela educação [...] isso atrapalha muito porque antes as pessoas davam mais valor à educação (Diretora adjunta da Escola Azul).

A mesma pessoa, ao ser indagada sobre o papel da escola, diz que:

[...] a escola como grupo social importante tem como um de seus objetivos trabalhar o convívio social, só que assim, ao meu ver, é trabalhar a interação social, mas não é implementar o valor em cada criança, porque eu acho que os valores deveriam ser implementados em cada criança pela família. E hoje em dia tá complicado porque a gente além de ensinar os conteúdos temos de ensinar os valores que a criança deveria trazer de casa, a gente só moldaria de acordo com a interação social (Diretora adjunta da Escola Azul).

Em outra entrevista com uma professora da mesma escola, quando indagamos qual era o tema que mais aparecia em suas reuniões com os responsáveis pelos alunos ela disse que era a:

[...] indisciplina, ela acaba prejudicando, a gente perde muito tempo para controlar a turma até você fazer com que eles se acalmem. Primeiro, leva um tempo para a adaptação no início do ano e depois que você consegue controlar, você tem de conter a indisciplina para poder dar uma aula. Até eles entenderem como você é, você tem de se impor mesmo. Tem de ser mais severa, depois você pode até relaxar, mas no começo leva muito tempo (Professora da Escola Azul).

As falas acima se complementam,pois, tanto no momento da reunião com os responsáveis pelos alunos quanto nas entrevistas com a representante da equipe de direção, há uma identificação da indisciplina escolar com um dos maiores problemas enfrentados pela escola.

O controle sobre as crianças, sobre seus corpos, sobre suas ações é uma “obsessão" perseguida pelas escolas de maneira geral. Segundo os profissionais 
que entrevistamos a indisciplina quebra o "funcionamento" normal da instituição e lhe impõe desafios que nem sempre ela dá conta. O fato novo, na situação retratada aqui, é que a escola convoca a família numa perspectiva de responsabilizá-la pela indisciplina de suas crianças.

Fica evidente que a escola não propõe um diálogo sobre a questão da disciplina/indisciplina. Ela afirma que essa questão decorre da falta de "valores" que as famílias deixam de criar em suas crianças. Porém, não se discute qual é o conceito de disciplina e nem as razões que implicam num comportamento desviante e muito menos de que modo a escola contribui para a indisciplina de seus próprios alunos.

Talvez uma das explicações para esse descompasso entre escola e famílias seja a projeção de um tipo ideal de aluno realizado pelos profissionais da escola. Ou seja, a escola espera por uma criança que esteja pronta - e nos indagamos se essa criança existe em algum lugar - para ser o "aluno perfeito", obediente, pacífico e comprometido com as lições e deveres que lhes são impostos.

Voltando à reunião com os responsáveis pelos alunos, nos chamou a atenção a falta de uma pauta previamente construída e divulgada. Ao perguntar às pessoas que ali estavam sobre os assuntos a serem tratados, elas simplesmente não sabiam ou sabiam que era uma reunião do Bolsa-Família. Por outro lado, a impressão que tivemos é que os assuntos surgiam sem uma sequência lógica e iam sendo tratados quando eram lembrados, ficando em nós a impressão de que a reunião e os conteúdos apresentados não foram planejados de forma adequada à importância do encontro com as famílias.

Durante o encontro, houve um momento em que foi proposta a maior participação dos responsáveis pelos alunos nos assuntos da escola. A equipe de direção disse que gostaria de criar uma semana em que um pai e um aluno auxiliariam a direção da escola. A ideia era fazer com que os responsáveis e os alunos pudessem ter uma experiência nas decisões da escola e que isso servisse para aproximar mais escolas e famílias. A proposta nos pareceu interessante e inovadora.

Outra medida anunciada foi que o Grêmio Escolar deveria passar a ajudar nas decisões a respeito de um evento que seria realizado no "dia das crianças" a ser organizado em outubro de 2016. Nesse evento, a escola alocaria recursos para 
contratar "recreadores", alugar brinquedos e comprar doces e salgados. A festa seria apenas para as crianças e os responsáveis não poderiam participar.

Durante mais ou menos uma hora, apenas a equipe de direção falou, inclusive sobre as questões referentes à violência que paralisou a escola em alguns dias. Não houve, no entanto, um aprofundamento desse tema ou quaisquer sugestões no sentido de procurar soluções ou medidas que atenuassem o problema da perda dessas aulas.

Aos responsáveis foi reservado, no final da reunião, um tempo para a formulação de perguntas, que foram feitas por poucas pessoas, sendo que a maioria das perguntas se concentrou no tema das matrículas para o ano de 2017.

O curto tempo destinado aos responsáveis, apenas ao final da reunião, pareceu inibir a participação das famílias dos alunos e dificultar a colocação de questões mais delicadas que talvez devessem ser tratadas no início do encontro como, por exemplo, a reposição de aulas perdidas por conta das paralisações forçadas pela violência.

Por fim, a equipe de direção pediu aos responsáveis que anotassem, antes de sair, numa folha de papel dada pela escola o que cada um esperava para o ano de 2017. Foi possível verificar, posteriormente, que alguns desses pedidos ficaram expostos em um mural da escola.

A nossa percepção mais geral foi a de que os responsáveis que compareceram à reunião estavam interessados no conteúdo apresentado. No entanto, a falta de um microfone, por exemplo, tornou por vezes difícil a escuta do que se dizia. Além da falta de planejamento da reunião, também sentimos falta de um "acolhimento" melhor dos familiares dos alunos por parte da escola, de forma a criar um ambiente mais próximo e que contribuísse para promover uma maior participação dos responsáveis.

Por outro lado, a solicitação aos responsáveis para que manifestassem suas expectativas para o ano seguinte, feita por escrito, não levou em conta que muitos familiares têm dificuldades de se expressar dessa maneira devido a uma escolarização precária ou à tradição de cultura oral como forma preponderante de comunicação.

Assim, momentos que poderiam ser transformados em encontros produtivos com trocas de informações e de experiências e de abertura para uma maior 
interação escola-família acabam perdendo força justamente porque a comunicação não é cuidada como deveria. Isto nos parece ser uma das dimensões do descompasso existente entre o funcionamento do mundo escolar e o funcionamento do mundo do aluno.

No mesmo dia, foi possível acompanhar a reunião de pais das Escolas Branca. Já que há concomitância de reuniões segundo uma orientação da SME-RJ no sentido de que as reuniões entre escolas e famílias acontecem aos sábados para que os responsáveis tenham mais chances de comparecer.

$\mathrm{Na}$ Escola Branca, a reunião foi feita no pátio de entrada e contabilizamos, pelo menos, 70 pessoas, a maioria mulheres. O pátio é coberto, mas como o portão de entrada é um gradeado de ferro, o barulho da rua invadia a reunião. Havia ainda muitas crianças pequenas que corriam pelo pátio, o que contribuía para dificultar a escuta do que era falado.

A diretora da escola apresentou um Power Point sobre a importância da prevenção do câncer de mama. Essa atividade, no entanto, foi realizada sem microfone e, por isso, as pessoas que se sentaram na parte de trás do pátio não conseguiam ouvir quase nada. Algumas dessas pessoas reclamaram que a equipe de direção "falava muito".Uma das mulheres presentes disse à outra ao seu lado que tudo aquilo ela já sabia através do posto de saúde. O mesmo já tinha sido reconhecido pelos professores entrevistados como um dos principais parceiros da escola.

Pelo que pudemos apurar, o posto de saúde realiza, de tempos em tempos, palestras para seus pacientes e para a população local sobre os temas que estavam sendo tratados pela escola.Levando em conta as possibilidades oferecidas pela relação escola-território, foi inevitável questionarmos por que a equipe de direção não convidara alguém do posto de saúde para falar sobre assuntos ligados à área de saúde. E, ainda, por que não escolher outro tema no campo da educação aproveitando a presença de tantos responsáveis e familiares?

Ao final do encontro, perguntamos à equipe de direção de que maneira eram escolhidos os temas tratados nas reuniões. Fomos informados que os temas eram aqueles que a escola achava mais importantes ou que sentia necessidade de tratar e que os responsáveis não participavam dessa escolha. Ora certamente essa postura 
não colabora para a comunicação da escola com o seu público e para o estreitamento das relações entre a escola e as famílias.

Nas entrevistas posteriores, indagados sobre esse assunto, os profissionais da Escola Brancanos disseram que havia falta de interesse e de mobilização dos pais para participar da vida e das decisões escolares e isto justificaria a falta de consulta sobre os temas de abertura das reuniões.

$\mathrm{Na}$ própria reunião com os responsáveis a equipe de direção se queixou explicitamente da falta de interesse e de mobilização das famílias para resolver problemas comunitários.

Como na Escola Azul, na Escola Branca, também não houve divulgação de uma pauta prévia ou uma consulta aos responsáveis pelos alunos sobre que assuntos eles gostariam de tratar na reunião. As pessoas ficaram sabendo do que seria tratado durante o encontro.

Apesar da longa duração do encontro, quase três horas, houve imprecisão nas informações passadas o que gerou muitas dúvidas como foi o caso, por exemplo, do processo de matrículas para o ano seguinte e a determinação da SME-RJ para que todas as escolas da Maré se transformassem em escolas de horário integral.

Em especial duas questões nos chamaram a atenção. A primeira diz respeito à programação de uma festa de "ação de Graças" que aconteceria na escola, próxima ao Natal. Esse, segundo a equipe de direção, seria um evento aberto aos pais e a proposta seria promover um "agradecimento a Deus" pelas realizações do ano; a segunda questão diz respeito ao final das aulas. Foi avisado aos responsáveis que, no início de novembro, haveria um conselho de classe e que as crianças que estivessem com bons conceitos seriam dispensadas a partir do início de dezembro. No entanto, as aulas continuariam por imposição da SME-RJ, mas os responsáveis pelos alunos que achassem por bem não enviar mais as crianças já aprovadas à escola, não encontrariam problemas.

O último recado dado pela escola foi o de que haveria uma formatura para as crianças pequenas ao final do ano letivo. A equipe de direção pediu a presença dos responsáveis e reclamou que, na maioria das vezes, nessas formaturas não havia ninguém das famílias. Como a formatura seria num dia de semana, durante as aulas, sugeriu-se aos responsáveis que pedissem a liberação do trabalho junto a 
seus patrões ou que enviassem alguém da família, pois esse seria um momento muito importante para as crianças.

Em primeiro lugar, é preciso questionar a pertinência de um evento de cunho religioso em uma escola pública que deve ser laica. Em segundo lugar, é preciso pensar outras estratégias para que os responsáveis possam comparecer a eventos de formatura, já que não parece razoável propor simplesmente que eles peçam dispensa de seus empregos para comparecer ao evento.

Por fim, ao término da reunião, as pessoas foram chamadas para assinar a lista de presença que é obrigatória para aquelas que recebem o benefício do Bolsa Família e do Cartão Carioca. Houve, nesse momento, certo tumulto, pois todos receberam uma senha no começo da reunião e deveriam assinar a lista de presença de acordo com a ordem de chegada representada pelo número da senha. A lista foi disponibilizada propositalmente, segundo a equipe de direção, ao final do encontro para evitar que as pessoas fossem embora antes do fim da reunião.

No entanto, o que constatamos foi que a assinatura do documento, mesmo com a distribuição de senhas, foi desordenada. As pessoas foram divididas segundo a turma dos filhos, mas as indicações do local para o qual deveriam se dirigir, já que havia três mesas separadas com listas diferentes, não eram claras. Isso fez com que as "filas" se misturassem e confundissem ainda mais as pessoas.

Ouvimos a reclamação de uma mãe de aluno que chegou após o início da reunião e não recebeu a senha. Ela reclamava de ter de ficar por último para assinar alista. Por sua vez, outras pessoas que chegaram atrasadas também não receberam senha. Uma pessoa da equipe de direção, em tom de brincadeira, se dirigiu a algumas senhoras que esperavam sem senha e disse que "elas estavam de castigo". Essas senhoras foram as últimas a assinar a lista. Não nos parece que esse tipo de atitude ajude a aproximar a escola dos responsáveis.

As reuniões de pais nas duas escolas observadas têm pontos em comum que nos chamaram a atenção. $\mathrm{O}$ primeiro ponto diz respeito ao fato de que, nas duas escolas, foi a equipe de direção quem falou durante a maior parte do tempo da reunião, denotando que há uma cultura da escola em falar muito e ouvir pouco.

Mesmo quando foram abertos espaços para a fala dos responsáveis, isso aconteceu sempre depois que a escola já havia colocado todas as suas questões. Assim, a abertura de momentos para a fala dos responsáveis sempre foi deixada 
para o final dos encontros, quando a maioria das pessoas já estava cansada e pronta para ir embora.

A falta de uma preparação prévia das reuniões também foi percebida durante a observação. Em ambas as escolas não houve divulgação prévia dos assuntos a serem tratados e o improviso foi a regra. Isso, aliado à falta do uso de microfone, dificultou a troca de informações e a interação escola-família.

Outro evento que presenciamos, na Escola Azul, ao longo de nossas visitas,e que segue uma linha parecida com o "dia de ação de graças" promovido pela Escola Branca, foi o fato de que em todas as manhãs e tardes, antes do início das aulas, as turmas ficavam perfiladas no pátio de entrada junto com os professores, a equipe de coordenação e a direção para rezar a oração do "Pai Nosso".

Perguntamos a vários profissionais da Escola Azul a razão desse ritual e todos foram unânimes em dizer que era um processo importante porque "acalmava as crianças" e as ajudava na concentração nas aulas. Indagados sobre a questão da laicidade, os profissionais da escola disseram que isso não infringia esse valor republicano porque a escola era laica e o ritual era apenas uma metodologia usada para ajudar a "começar bem as aulas".

Indagados ainda sobre as famílias que podiam não concordar com o ritual ou que simplesmente podiam ter outro tipo de religião, os profissionais da escola disseram que as crianças cujas famílias não concordavam poderiam ficar num canto, fora da formação das turmas.

Junto com o dia de Ação de Graças promovido pela Escola Branca, o ritual da oração do Pai Nosso se contrapõe aos valores de laicidade e republicanismo defendidos pela escola pública, por melhores que sejam as intenções.

Assim como a questão da disciplina, cuja promoção a escola acredita ser dever da família, a oração coletiva do Pai Nosso praticada na Escola Azul, revela mais uma faceta do desencontro entre escolas e famílias. O pressuposto básico nos dois casos é o de que as famílias não socializam seus filhos como deveriam. Essa visão da escola sobre a família denota a antinomia presente nos processos de socialização diferenciados praticados por escolas e famílias.

O conjunto desses fatos cria um ambiente pouco favorável ao encontro positivo entre escolas e famílias. Claro que não se podem esquecer as muitas 
dificuldades impostas a essa relação pelas questões específicas do território como, por exemplo, a violência dos grupos criminosos. Ou a falta de um investimento maior da SME-RJ, dado que não há cursos ou atividades de formação para os profissionais da educação que trabalham na Maré e nas favelas cujo tema seja a relação com as famílias.

Assim, pelo que observamos, as diferenças entre as Escolas 1 e 2, não são significativas no que diz respeito às relações com as famílias. Não foi possível identificar evidências de práticas da escola participante do PEA/BE (Escola Azul), voltadas para uma maior integração com as famílias e com a vizinhança.

Na verdade, o que constatamos é que, na Maré, as relações escola-famíliavizinhança não escapam aos padrões de distanciamento, falta de comunicação e antinomia apontados pela literatura e pelas pesquisas empíricas que vimos aqui.

\section{9 \\ Notas sobre o PEA/BE na Maré}

Muito embora, como já afirmamos em outras passagens deste trabalho, nossa intenção não seja a de fazer uma avaliação do PEA/BE, faremos algumas considerações sobre o programa a partir do que os agentes envolvidos revelaram nas entrevistas que concederam.

Em primeiro lugar, consideramos que a ideia de criar um programa educacional que se aproxime do que qualificado como uma PEP, nos moldes do que discutimos no capítulo 1, é uma iniciativa importante da SME-RJ. Principalmente quando se dirige às escolas que apresentam indicadores educacionais abaixo do esperado e, em especial, às unidades localizadas em territórios pobres e vulneráveis da cidade.

Outro fator que consideramos positivo foi a composição do PEA/BE que procurou combinar incentivo à melhoria do desempenho escolar, a partir de uma série de ações que estimulavam uma abordagem curricular diferente e o reforço em disciplinas escolares como língua portuguesa, matemática e ciências, com uma aproximação de famílias e vizinhança escolar.Esta última ação foi desenvolvimento a partir da metodologia do Bairro Educador.

Se o desenho do PEA/BE pode ser considerado interessante, quando passamos a observar sua aplicação em territórios específicos da cidade, como no 
caso da Maré, percebemos que existem muitos problemas a serem superados.O primeiro problema diz respeito ao fato de que o PEA/BE, ao contrário das PEP, não pensa nas ações como um conjunto de intervenções nos territórios. $\mathrm{Na}$ verdade, as ações focaram mais especificamente nas escolas e seus profissionais. Acreditamos que isso pode ser um equívoco. No caso da Maré, por exemplo, onde temos dez estabelecimentos de ensino participando do programa, não há um projeto que pense mais integralmente o território. Ou seja, não há uma política integrada para as escolas da Maré. A impressão que se tem é que elas trabalham de forma isolada, cada uma na sua área, com seu público, como sempre fizeram.

Ouvimos, por exemplo, a reclamação dos profissionais da escola e dos responsáveis pelos alunos a respeito do problema da violência dos grupos armados e de como os confrontos com a polícia atrapalham a rotina escolar. Essa é uma questão inescapável para qualquer formulador de políticas públicas para a região, no entanto, como constatamos não havia, como ainda não há, um plano de ação sobre o que fazer a esse respeito.

Pode-se alegar que essa é uma questão maior do que as próprias escolas e maior até mesmo do que a prefeitura. Porém, ter um planejamento que comporte orientações gerais para proteger as escolas, seus agentes e os responsáveis pelos alunos e, na sequência, pensar um calendário de reposição de aulas, é algo bastante factível e desejado.

Podemos arriscar que um dos erros do PEA/BE foi não considerar os territórios e seu impacto sobre o trabalho das escolas, apesar de isso aparecer em alguns de seus documentos fundadores. Não conseguimos identificar, por exemplo, estudos ou diagnósticos sobre os territórios onde as escolas que fazem parte do programa atuam. E aí fica a questão: como planejar adequadamente se não há uma visão clara, com dados concretos, acerca da realidade onde se quer intervir?

Obviamente, temos clareza de que não se resolveriam os problemas apenas com um bom diagnóstico e um bom planejamento que levassem em conta o território, pois, como vimos, a partir do estudo de algumas PEP, a realidade é bem mais complexa do que comportam os estudos sobre o local. Contudo não levar em consideração o território em sua "integralidade fragmentada", seus desafios, 
problemas e potencialidades é um passo para desacertos que podem levar ao fracasso de uma boa ideia.

Um bom exemplo da falta de um planejamento mais adequado reside no processo de escolha das 155 escolas que fazem parte do PEA. Ao conversarmos com os gestores do Programa, eles não souberam explicar quais foram os critérios utilizados - salvo a utilização de indicadores de baixo rendimento e de localização em áreas "conflagradas", que podem também ser questionados para se chegar ao número final de escolas.

Quando observamos os resultados gerais das escolas que participam do PEA/BE, verificamos que houve uma leve melhora ${ }^{40}$ que acompanhou, grosso modo, a evolução da rede municipal da cidade do Rio de Janeiro. O que é um bom resultado se considerarmos as muitas dificuldades enfrentadas por essas escolas. Porém, quando fazemos o recorte territorial e olhamos para a Maré, verificamos que os efeitos do programa ainda estão muito aquém do esperado, não sendo possível afirmar com segurança que existem diferenças significativas de desempenho entre as escolas que podem ser atribuídas a participação no PEA/BE.

A partir das observações que realizamos nas escolas e das entrevistas com seus profissionais e com os responsáveis pelos alunos, constatamos que a eventual melhoria de alguns indicadores escolares, sobretudo na Escola Azul, se relaciona mais diretamente com as decisões tomadas pela de direção do que com o PEA/BE.

Se pudermos considerar os resultados escolares das escolas da Maré, que participam do programa abaixo do esperado, o mesmo pode ser dito sobre o processo de aproximação entre as escolas com as famílias e com a vizinhança escolar. Essa aproximação das escolas com seu entorno e com as famílias de seus alunos é descrito como uma das ações mais importantes pelos gestores do Programa em seu início. No entanto, com base em nossas observações empíricas e nas entrevistas realizadas, não foi possível encontrar diferenças significativas nas relações estabelecidas entre as escolas e as famílias na Escola Azul, participante do Programa, e a Escola Branca, não participante.

Como pudemos observar, por exemplo, a partir da descrição das reuniões com os responsáveis, se as relações não podem ser consideradas ruins, também

\footnotetext{
${ }^{40}$ Site Rio Educa. Disponível em http://www.rioeduca.net/programasAcoes.php?id=19. Acesso em abril de 2017.
} 
não podem ser descritas como melhores do que a média. Na verdade, o modo como a Escola Azul desenvolve suas relações com as famílias e com o seu entorno é bastante similar ao da Escola Branca. Não constatamos diferenças significativas.

Por exemplo, quando perguntamos a uma das agentes sociais da Escola Azul, sobre as famílias e a comunidade/favela, ela respondeu da seguinte forma:

Numa comunidade tem muita gente que se entrega a álcool [...], trabalhei num CIEP, no "Mais Educação", e tinha criança que não tinha aula, a gente ligava e a mãe não atendia. Eu tive que parar, descobrir onde a criança morava [...] chego lá, era uma segunda-feira, 7 h30 da manhã, a mãe tava com o som alto e bebendo cerveja com várias pessoas na casa, segunda-feira, às 7 h30 da manhã! Ah, pode ser que isso aconteça em Botafogo? Pode. Mas a probabilidade de acontecer aqui é maior (Professora da Escola Azul).

Quando repetimos essa mesma pergunta para um dos profissionais da

Escola Branca, ele nos respondeu da seguinte maneira:

A maioria das famílias é complicada. O negócio é complicado. Formação familiar mesmo, pai, mãe, padrasto, madrasta..., as vezes todo mundo mora junto... eu acho até para você ter aprendizado, você tem de ter um pouco de estrutura e paz. Coisas que eles não têm aqui. Eu acho que essas 24 h de intensidade em que eles vivem acabam gerando essas coisas, essas dificuldades que eles têm aqui [...]. Noto isso porque nas famílias que são um pouco mais estruturadas as crianças têm um desenvolvimento melhor (Professor da Escola Branca).

É interessante observarmos a partir dos trechos citados que algumas ideias persistem na imagem que as escolas fazem das comunidades e das famílias. Há, como vimos no primeiro depoimento, a ideia de que nas comunidades/favelas as condutas vistas como desviantes são maiores.A comparação feita pela professora entre a Maré e um bairro da zona sul da cidade deixa isso claro. Embora ela reconheça que tais comportamentos, tidos como impróprios, possam acontecer em outros pontos da cidade, inclusive nos bairros de classe média, existe a crença de que na Maré eles sejam muito mais frequentes.

O segundo depoimento demonstra a permanência da ideia de que as famílias na Maré são "desestruturadas". O professor evoca a diversidade de arranjos familiares, nos quais conviveriam pessoas cujos laços não se resumem aos "tradicionais". Aqui se enfatiza uma conformação familiar que já não corresponde à realidade em muitas casas brasileiras, não só nas casas da favela. 
Assim, uma composição familiar diferente da tradicional evoca uma imagem de desorganização familiar cujo reflexo seria o mau desempenho escolar das crianças. Contudo, precisamos perguntar como se pode provar que as composições familiares diversas têm reflexos negativos diretos no aprendizado escolar? O que seria uma família "estruturada"? Essas são questões com as quais a escola trabalha e que compõem parte importante da construção do olhar de seus agentes sobre as famílias e as crianças de origem popular.

Para nós, o olhar construído pela escola acerca das famílias e de sua vizinhança é fundamental para definir que tipo de relações serão estabelecidas. Esse é um ponto onde o PEA/BE falhou. Ou seja, apesar de uma de suas ações mais importantes estar centrada justamente na relação dos profissionais da escola com as comunidades/favelas e com as famílias, não houve um investimento na formação dos professores no que concerne às questões familiares e nem discussões mais aprofundadas sobre os espaços populares onde as escolas atuam.

Ao indagarmos os profissionais da escola e os gestores sobre que tipo de formação o programa ofereceu, não encontramos ações direcionadas ao tema escola-família. Alguns professores se queixaram dessa falta de investimento e afirmaram que se sentiram desamparados, não sabiam como agir diante das questões trazidas pelas crianças pobres. Por isso, acreditamos que o PEA/BE deveria apostar na formação de seus professores no que diz respeito a uma maior aproximação com a realidade das favelas cariocas e do público que as escolas localizadas nesses espaços atendem. Isso poderia melhorar substancialmente as relações escola-famílias-vizinhança.

Outra questão importante que detectamos em nossa pesquisa foi a mudança de foco efetuada, em 2011, pela SME-RJ na condução do Programa. Nesse ano, segundo um dos gerentes do PEA/BE, todas as ações ficaram subordinadas a uma única meta: aumentar o desempenho escolar, ou seja, aumentar os resultados do IDEB. Isso significou um redimensionamento das ações do Bairro Educador que passou a focar mais no reforço escolar do que propriamente no estreitamento das relações com a vizinhança. Não temos dúvida que essa mudança de foco enfraqueceu o trabalho de aproximação das escolas com o território e a construção de parcerias locais. 
Em 2013, o Bairro Educador deixou de ser uma ação do Programa Escolas do Amanhã. Até onde pudemos apurar, isso estava previsto desde a implementação do Programa, já que a ideia era que as próprias escolas assumissem as ações que até então desenvolvidas com a ajuda de uma instituição da sociedade civil. A questão que colocamos é que não houve uma avaliação mais aprofundada para saber se, de fato, as escolas, pelo menos a maioria delas, poderia realmente assumir sozinhas as parcerias e as redes de apoio que teriam sido construídas.

Aliás, esse é um dos maiores problemas no desenvolvimento de políticas públicas no campo da educação. Muitas ações são planejadas sem o devido diagnóstico prévio da realidade a ser enfrentada e são encerradas sem a devida avaliação dos resultados. Essa situação cria descontinuidade e, por vezes, perdas econômicas e educacionais significativas.

Pudemos verificar o problema apontado acima, por exemplo, quando indagamos nossos entrevistados, principalmente os profissionais da escola e os responsáveis pelos alunos, acerca do seu conhecimento do Programa Escolas do Amanhã e do Bairro Educador.

Nos surpreendemos com o desconhecimento dos entrevistados acerca do Programa. Apenas a diretora da Escola Azul possuía razoável conhecimento sobre os objetivos e funcionamento do PEA/BE. Os demais, incluindo alguns gestores, tiveram dificuldades para explicar o que era o Programa e como deveria funcionar. Desse modo, uma boa parte dos nossos entrevistados disse ter "ouvido falar" do PEA a partir da última campanha das eleições para a Prefeitura da cidade do Rio de Janeiro, mas não saberia dizer o que era exatamente.

Quando perguntamos especificamente sobre o Bairro Educador, à exceção da diretora da Escola Azul e dos gestores, nenhum dos entrevistados, professores e responsáveis, soube dizer de que se tratava. A maioria, incluindo as professoras da Escola Azul que já atuavam na escola quando o Bairro Educador foi implantado, nunca tinham ouvido falar do Projeto. Isso nos chamou a atenção, pois o Bairro Educador funcionou durante três anos na Maré, em dez escolas.

A conclusão a que chegamos é a que o Bairro Educador não conseguiu se materializar na Escola Azul nem se consolidar na Maré. Responsáveis pelos 
alunos moradores de outras comunidades/favelas da Maré e que frequentaram outras escolas participantes do Projeto também não identificaram sua existência.

Assim, embora seja uma política pública que procurou inovar no campo da educação da cidade do Rio de Janeiro, é correto dizer que os efeitos do Programa Escolas do Amanhã e de Bairro Educador na Maré ficaram aquém do esperado. E por conta das dificuldades elencadas acima, o PEA/BE não conseguiu cumprir a promessa de aproximar suas escolas das famílias da Maré e de sua vizinhança.

As ações do Programa deveriam ser repensadas, levando em conta a necessidade de investimento maior na formação dos professores que privilegiem o tema das relações escola-família-vizinhança. Também sinalizamos para a importância da criação de espaços escolares a serem ocupados pelas famílias dos alunos de forma a superar a condição meramente formal do CEC. A incorporação no planejamento de diagnósticos e avaliações que levem em conta o território como fator preponderante no trabalho escolar e o comprometimento da SME-RJ, sobretudo das CREs, com o trabalho de aproximação escola-família-vizinhança seriam outras ações a serem consideradas para o sucesso de ações semelhantes. 
Considerações finais

Todos os dias mais de dezesseis mil crianças e jovens moradores do conjunto de favelas da Maré, maior favela da cidade do Rio de Janeiro, deixam suas casas em direção às escolas públicas da região ${ }^{41}$.Mães, pais, vizinhos, irmãos, avós e avôs, tios e tias acompanham essas crianças e jovens, muitas delas simplesmente vão sozinhas para a escola.

As ruas ficam cheias e o som de passos apressados, das conversas animadas e das brincadeiras despertam a favela. Nas escolas, estima-se que cerca 550 profissionais de educação recebam esse contingente de estudantes.

A rotina escolar é uma das mais importantes atividades sociais e um dos acontecimentos que mais marca a vida cotidiana na Favela da Maré. Contudo, muitas das vezes, chegar à escola e manter essa rotina não é tarefa das mais fáceis. É preciso driblar alguns obstáculos pelo meio do caminho e manter firme a determinação de chegar à escola.

Um desses obstáculos é a questão da violência armada dos grupos criminosos locais. Os conflitos crescentes entre esses grupos e entre eles e a polícia têm dificultado muito o trabalho e a vida dos profissionais de educação e dos familiares das crianças. O fato é que os confrontos armados produzem significativas perdas para as crianças e suas famílias, porque muitas escolas da Maré suspendem suas atividades em razão das operações policiais ou das disputas entre grupos criminosos rivais.

As aulas chegaram a ser suspensas durante vinte dias letivos intercalados em 2016, representando num prejuízo pedagógico irrecuperável, já que, na maioria dos casos, as aulas perdidas não são repostas. Isso coloca as crianças da Maré em grande desvantagem,prejudicando sobremaneira sua trajetória escolar.Existem ainda outros obstáculos que se colocam no caminho de uma trajetória escolar mais longa para as crianças da Maré. A constante falta de professores nas escolas e sua

\footnotetext{
${ }^{41}$ A Maré contava até o ano de 2016 com 16 escolas públicas. Neste ano a Prefeitura da cidade inaugurou mais dez escolas e a promessa para o ano de 2017 e que mais dez sejam inauguradas. Segundo a Secretaria Municipal de Educação-RJ o objetivo é que todas as escolas da Maré passem a oferecer tempo integral. Assim, a Maré deverá ter perto de quarenta instituições de ensino incluindo-se nessa conta pelo menos mais quatro creches - para atender a demanda local.
} 
grande rotatividade, assim como o alto índice de reprovação escolar que ainda é um problema particularmente presente na Maré, além da falta de políticas públicas integradas que melhorem os indicadores sociais locais.

Contudo, mesmo considerando essas dificuldades, os responsáveis continuam a pautar a rotina das famílias pela rotina escolar. Enfrentam todos os obstáculos apontados acima para que as crianças possam ir à escola na tentativa de construir e manter uma trajetória escolar regular e de sucesso.

Ao final desta pesquisa nos perguntamos: diante de tantas dificuldades o que move essas pessoas?

Sem dúvida, a resposta reside no interesse e na aposta firme das famílias em um futuro melhor para seus filhos e filhas. Em todas as entrevistas que realizamos com os responsáveis para este trabalho, essa foi a resposta mais recorrente. Para as famílias, o desejo é que suas crianças alcancem um nível de educação escolar superior ao de pais, mães e responsáveis. O desejo, como em qualquer família, é que as novas gerações possam ir além do que foram as gerações anteriores.

Pesquisas e estudos apontam que, nas classes populares, não é comum o entendimento do "jogo escolar" ${ }^{42}$, o que, entretanto, não impede que as famílias mais pobres apostem e invistam o pouco capital de que dispõem na formação escolar de suas crianças.

Pudemos observar, por exemplo, que muitas famílias fizeram sacrifícios significativos para que suas crianças pudessem ter maiores oportunidades de uma educação escolar melhor. Por exemplo, conversamos com uma mãe de aluno que, em acordo com o marido, deixou de trabalhar para acompanhar mais de perto a educação escolar do filho. Isso impôs uma série de restrições econômicas à família, que, segundo ela, foram recompensadas pela perspectiva de um futuro melhor para seu filho, baseada na possibilidade de ele "chegar mais longe" a partir de uma trajetória escolar de sucesso.

Para as famílias da Maré, a escola e a escolaridade são vistas também como elementos importantes para a construção de uma vida profissional mais promissora. Contudo, a instituição escolar aparece, ao mesmo tempo, como o lugar onde se aprendem valores cidadãos, o "comportamento adequado" e a "respeitar

\footnotetext{
${ }^{42}$ Este muito mais próximo do mundo das classes médias e ricas como apontados por autores como Bourdieu (2008).
} 
as pessoas", como foi visto nos depoimentos de professores e responsáveis pelos alunos durante as entrevistas realizadas para este trabalho.

Isto nos remete ainda para o tema dos obstáculos interpostos à escolaridade das crianças da Maré. Para além da questão da violência, existe uma antinomia entre as lógicas socializadoras da escola e das famílias de origem popular que também se faz presente na Maré. Na verdade, a relação entre escolas e famílias, sobretudo, as que moram em territórios como a Maré, apesar de uma aparente "tranquilidade", é marcada por desencontros, mal-entendidos e armadilhas que fazem com que escolas e famílias trilhem rotas distintas e, às vezes, até antagônicas.

Consideramos que essa questão é um dos aspectos mais relevantes para o sucesso escolar das crianças de origem popular. Reconhecer que a relação escolafamília precisa ser cuidada e enfrentada de outra maneira é fundamental. Isso envolve discutir o papel e o sentido da escola contemporânea, principalmente aquelas localizadas nos bairros e nos territórios populares, em especial nas favelas cariocas.

Nesse sentido, é capital entendermos que as favelas possuem singularidades que precisam ser observadas com cuidado para que os projetos escolares - ou seriam projetos de escolas? - sejam organizados para atenderem as reais demandas locais.

A Maré é um território onde mais de $70 \%$ da população local é formada por crianças e jovens de até 30 anos, o que, por si só, o torna singular. Existem muitas iniciativas no campo da cultura, da arte e da educação realizadas pelos moradores; existem muitas ONGs locais que atuam na preservação e garantia de direitos básicos e existem espaços culturais, igrejas e um comércio local intenso.

Esse conjunto de instituições e suas ações geram uma vida intensa e positiva que escapa aos estereótipos que insistem em reduzir a favela e seus moradores a meros coadjuvantes da violência dos grupos locais. Muito embora a violência seja uma questão fundamental, ela não pode ser usada como escusa pelo poder público para descumprir o papel que lhe cabe no território.

Mais uma vez, observar com cuidado a constituição e o funcionamento dos territórios onde se localizam as escolas ganha, assim, grande importância, uma vez que a atenção para as especificidades territoriais pode conferir "sentido" 
maior à escola e à educação escolar e contribuir, inclusive, para que os níveis de evasão, reprovação e desempenho escolar melhorem sensivelmente.

Nesse contexto, iniciativas como o Programa Escolas do Amanhã e seu Projeto Bairro Educador precisam ser repensadas no sentido de levar em conta o território como um fator que coloca limites, mas também que oferece possibilidades para a ação pedagógica e social da escola.

Por outro lado, como pudemos constatar, se a literatura sobre a relação escola-família é extensa e antiga, as ações no Brasil e mais especificamente no Rio de Janeiro que consideram tais relações, incluindo-se aí o território, ainda são escassas e incipientes. Na verdade, excluindo os CIEPS de Darcy Ribeiro e Brizola, o PEA/BE foi a primeira grande ação na cidade que procurou pensar uma política educacional que levasse em conta o trabalho de escolas em territórios populares chegando a atingir $15 \%$ dos alunos da rede municipal. Nisso reside seu mérito.Porém, apesar de sua extensão, o programa parece não ter conseguido avançar, na escola estudada, em questões chaves relativas à aproximação escolafamília-vizinhança, e nem ter sido capaz de deixar um legado consistente que possa ser assumido pela escola onde foi implementado, como se depreende da comparação entre as Escolas Azul e a Escola Branca

O fato de não ter sido possível apontar diferenças substanciais quanto à forma de acolhimento, comunicação e relacionamento com as famílias e a vizinhança entre as escolas estudadas, nos leva a concluir que as relações entre escolas-famílias-vizinhança na Maré ainda são marcadas pela distância, pela comunicação precária e pelos estigmas que os territórios pobres da cidade carregam. Essa relação tal como se dá hoje pode limitar bastante as chances e oportunidades das crianças da Maré de ter atendido seu direito a uma educação de qualidade.

Nosso estudo sugere, por fim, a necessidade de se questionar a concepção e a metodologia aplicadas pelas políticas públicas que, como o PEA/BE, se destinam a territórios como a Maré. Também sugere a necessidade de se repensar o funcionamento da "forma escolar", que ainda é preponderante em nossas escolas. Ela molda um determinado tipo de escola que foi projetado para as classes privilegiadas dos séculos XIX e XX, não dando conta, portanto, das reais necessidades e potencialidades das crianças dos meios populares do século XXI. 


\section{1}

\section{Referências bibliográficas}

ALVES, F.; FRANCO, F.C.; RIBEIRO, L.C.Q. Segregação residencial e desigualdade escolar no Rio de Janeiro. In: RIBEIRO, L. C. de Q.; KAZTMAN, R. (Org). A cidade contra a escola: Segregação urbana e desigualdades educacionais em grandes cidades da América Latina, Rio de Janeiro: Letra Capital, 2008.

ALVES, F.; LANGE, W.; BONAMINO, A. A geografia objetiva de oportunidades educacionais na cidade do Rio de Janeiro. In: RIBEIRO, L. C. de Q.; KOSLINSK, M. C.; LASMAR, C. (Orgs). Desigualdades Urbanas, desigualdades escolares. Rio de Janeiro: Letra Capital, 2010.

BALL, S. Sociologia das políticas educacionais e pesquisa crítico-social: uma revisão pessoal das políticas educacionais e da pesquisa em política educacional. Currículo sem fronteira, v.6, n 2, jul./dez. 2006.

BALL, S.; MAINARDES, J. Políticas educacionais: questões e dilemas. (Orgs.) São Paulo: Cortez, 2011.

BARONE, R. E. M. Educação e políticas públicas: questões para o debate. Núcleo de Gestão Pública, UNIEMP-Fórum Permanente das Relações Universidade e Empresa, 1999.

BATISTA, A. A. G.; SILVA, H. H. de C. Família, escola, território vulnerável. São Paulo: CENPEC, 2013.

BAUMAN, Z. Comunidades: a busca por segurança no mundo atual. Rio de Janeiro: Zahar, 2003.

BONAMINO, A. Os efeitos das diferentes formas de capital no desempenho escolar: um estudo à luz de Bourdieu e de Coleman. Revista Brasileira de Educação, v. 15, n. 45, p. 487-499, 2010.

BOURDIEU, P. A Miséria do mundo. Petrópolis: Vozes, 2008.

BOURDIEU, P; PASSERON, J. C. A reprodução. Elementos para uma teoria do sistema de ensino. Rio de Janeiro: Vozes, 2012.

BRANDÃO, Z.; MANDELERT, D.; PAULA, L. A circularidade virtuosa: investigação sobre duas escolas no Rio de Janeiro. Cadernos de Pesquisa, v. 35, n. 126, p. 747-758, 2005.

BRANDÃO, Z.; PAES, C. Processo de produção das elites escolares. Educação e Sociedade, Campinas, v.32, n115, p. 507-522, abr/jun. 2011.

BROCCOLICHI, S. Na zona das desigualdades. Disponível em: http://www.revistaeducacao.com.br/na-zona-das-desigualdades/2014. Acesso em fevereiro de 2015.

BROOKE; N.; SOARES, J. F. Pesquisa em eficácia escolar: origens e trajetórias 2008. Belo Horizonte: Editora UFMG, 2008.

BURGOS, M. B. Cidade territórios e cidadania. DADOS - Revista de Ciências Sociais, Rio de Janeiro, v. 48, n. 1, p. 189-222, 2005.

BURGOS, M. B.; RIBAS, J. A.; BRUNNELL, R. Projeto gestão Escolar e Territórios Populares: relatório de pesquisa. O responsável pedagógico de estudantes de escola pública: sua relação com a escola e sua percepção sobre o trabalho escolar. Estudo baseado com pais/responsáveis por estudantes das escolas públicas da Gávea. Departamento de Ciências Sociais/ Departamento de Educação. Rio de Janeiro: Puc-Rio, 2012 
BURGOS, M. B. (Org). A escola e o mundo do aluno: estudos sobre a construção social do aluno e o papel institucional da escola. Rio de Janeiro: Garamond, 2014.

BURGOS, M. B.; PAIVA, A. R. (Orgs.). A Escola e a Favela. Rio de Janeiro: PUC-Rio, 2009

CANO, I. Nas trincheiras do método: o ensino da metodologia das ciências sociais no Brasil. Sociologias, v. 14, n. 31, p. 94-119, 2012.

CARTA CIDADE EDUCADORA Disponível em: http://www.fpce.up.pt/ciie/OCE/docs/Cartadascidadeseducadoras.pdf. Acesso em fevereiro de 2015.

CENTRO DE INVESTIGAÇÃO E ESTUDOS DE SOCIOLOGIA (CIES); INSTITUTO UNIVERSITÁRIO DE LISBOA (ISCTE-IUL). Efeitos TEIP: Avaliação de impactos escolares e sociais em sete territórios educativos de intervenção prioritária. Lisboa: Ministério da Ciência e Educação, 2012.

CHARLOT, B. Da relação com o saber: elementos para uma teoria. Porto Alegre: Artes Médicas Sul, 2000.

CHRISTOVÃO, A. C. A vizinhança importa: desigualdades e educação no Morro do Cantagalo-RJ. 2009. 128 f: il.; $30 \mathrm{~cm}$. Dissertação de Mestrado, UFRJ, Instituto de Pesquisa e Planejamento Urbano e Regional: Rio de Janeiro, 2009.

CIEDS. Grêmio é fundamental: um guia para implementação. Rio de Janeiro, 2013.

CIEDS. Práticas e Aprendizagens: Um relato de experiências. Rio de Janeiro, 2013.

CIEDS. Traçado Metodológico: um caminho percorrido. Rio de Janeiro, 2013.

COSTA, M. V. Poder, discurso e política cultural: contribuições dos Estudos Culturais ao campo do currículo. Currículo: debates contemporâneos. São Paulo: Cortez, v. 2, 2002.

COSTA, M. V. (Org). O Currículo: nos limites do Contemporâneo. Rio de Janeiro: DP\&P, 2003.

CRAHAY, M. Poderá a escola ser justa e eficaz? Da igualdade das oportunidades à igualdade dos conhecimentos. Lisboa: Instituto Piaget, 2002.

DAYRELL, J. A escola como espaço sócio-cultural.Múltiplos olhares sobre educação e cultura. Belo Horizonte: Editora da UFMG, 1996.

DEROUET, J. Uma sociologia dos estabelecimentos escolares: as dificuldades para construir um novo objeto científico. In: FORQUIM, J. C. Sociologia da educação: dez anos de pesquisa. Petrópolis: Vozes, 1995.

DINIZ, E.; BELFORT, M. C.; RIBEIRO, P. Memória e identidade dos moradores do Morro do Timbau e Parque Proletário da Maré. Rio de Janeiro: Editora Redes da Maré, 2013.

DUBAR, C. A socialização: construção das identidades sociais e profissionais. Porto: Porto Editora, 1997.

ENGUITA, M. F. A ambiguidade da docência: entre o profissionalismo e a proletarização. Teoria \& Educação, Porto Alegre, 1991.

ÉRNICA, M.; BATISTA, A. A. G.Escola, a metrópole e a vizinhança vulnerável.Cadernos de Pesquisa v.42, n.146, maio/ago. 2012.

FLORES, C. Segregação residencial e resultados educacionais na cidade de Santiago do Chile. In: RIBEIRO; L. C. Q. ; KAZTMAN, R. (Org). A cidade contra a escola:Segregação urbana e desigualdades educacionais em grandes cidades da América Latina; Rio de Janeiro: Letra Capital, 2008. 
FORQUIN, J. Escola e Cultura: as bases sociais e epistemológicas do conhecimento escolar. Porto Alegre: Artes Médicas, 1993.

FUNDAÇÃO ITAÚ SOCIAL. Avaliação Econômica Programa Mais Educação. Disponível em: http://www.redeitausocialdeavaliacao.org.br. Acesso em outubro de 2016.

HAESBAERT, R. C.. O mito da desterritorialização: do "fim dos territórios" à multiterritorialidade. Rio de Janeiro: Bertrand Brasil, 2010.

KOSLINSKI, M. C.; ALVES, F.; LANGE, W. J. Desigualdades educacionais em contextos urbanos: um estudo da geografia de oportunidades educacionais na cidade do Rio de Janeiro. Educação \& Sociedade, Campinas, v. 34, n. 125, 2013.

LAHIRE, B. Sucesso escolar nos meios populares: as razões do improvável. São Paulo: Papirus, 2004.

LASMAR, C. (Orgs). Desigualdades Urbanas, desigualdades escolares. Rio de Janeiro: Letra Capital, 2010.

LEFEBVRE, H. Direito à Cidade. São Paulo: Editora Centauro, 2001.

LOPEZ, N. A escola e o Bairro. Reflexões sobre o caráter territorial dos processos educacionais nas cidades. In: RIBEIRO; L. C. Q. ; KAZTMAN, R. (Org). A cidade contra a escola: Segregação urbana e desigualdades educacionais em grandes cidades da América Latina; Rio de Janeiro: Letra Capital, 2008.

MINAYO, M. C. de S. (Org.). Pesquisa Social. Teoria, método e criatividade. Petrópolis: Vozes, 2001.

MOIGNARD, B. A escola e o território: um acordo democrático possível? In: BURGOS, M. B. (Org). A escola e o mundo do aluno: estudos sobre a construção social do aluno e o papel institucional da escola. Rio de Janeiro: Garamond, 2014. NOGUEIRA, C. M. M. A influência da família no desempenho escolar: estudo de dados da geração escolar 2005. Revista Contemporânea de Educação, v. 4, n. 8, 2009.

NOGUEIRA, M. A. A relação família-escola na contemporaneidade: fenômeno social/interrogações sociológicas. Análise Social, v. 40, n. 176, p. 563-578, 2005

NOGUEIRA, M. A. Família e escola na contemporaneidade: os meandros de uma relação. Educação \& Realidade, v. 31, n. 2, 2006.

NOGUEIRA, M. A. Relação família-escola: novo objeto na sociologia da educação. Paidéia, v. 8, n. 14/15, p. 91-103, 1998.

PATTO, M. H. S. A família pobre e a escola pública: anotações sobre um desencontro. Psicologia USP, v. 3, n. 1-2, p. 107-121, 1992.

PEREGRINO, M. Trajetórias desiguais: um estudo sobre os processos de escolarização pública de jovens pobres. Rio de Janeiro: Garamond, 2010.

RESENDE, T. F. Coragem para a luta": desafios e potencialidades da relação escola-famílias. Cadernos CENPEC, Minas Gerais, 2009.

RETAMOSO, A.; KATZMAN, R. Aprendendo juntos. Desafios na educação a partir dos processos de segregação urbana. RIBEIRO; L. C. Q. ; KAZTMAN, R. (Org). A cidade contra a escola:Segregação urbana e desigualdades educacionais em grandes cidades da América Latina; Rio de Janeiro: Letra Capital, 2008.

RIBEIRO, L. C. Q.; KOSLINK, M. C. Fronteiras urbanas da democratização das oportunidades educacionais: o caso do Rio de Janeiro. In: RIBEIRO, L. C. Q.; KOSLINK, M. C.; LASMAR, C. (Orgs). Desigualdades Urbanas, desigualdades escolares. Rio de Janeiro: Letra Capital, 2010. 
RIBEIRO; L. C. Q. ; KAZTMAN, R. (Org). A cidade contra a escola:Segregação urbana e desigualdades educacionais em grandes cidades da América Latina; Rio de Janeiro: Letra Capital, 2008.

ROCHEX, J. As três idades das políticas de educação prioritária: uma convergência européia? Educação e Pesquisa, São Paulo, v. 37, n. 4, dez. 2011.

ROMANELLI, G. Levantamento crítico sobre as relações entre família e escola. In: ROMANELLI, G.; NOGUEIRA, M. A.; ZAGO, N. (Orgs.). Família e Escola: novas perspectivas de análise. Petrópolis: Vozes, 2013.

RUI, C. Territórios educativos e políticas de intervenção prioritária: uma análise crítica. Perspectiva, Florianópolis, v. 22, n. 01, p. 47-78, jan./jun. 2004.

SANTOS, M. A natureza do espaço. São Paulo: EDUSP, 2009.

SAUL, P. R. As raízes renegadas da teoria do Capital Humano. Sociologias, Porto Alegre, ano 6, n. 12, p. 21-32, 2004.

SAVIANI, D. Escola e Democracia. Campinas: Autores Associados, 2012.

SEABRA, T. Estratégias familiares de educação das crianças. Sociologia, Problemas e Práticas, v. 23,p. 224-247, 2009.

SIBILIA, P. Redes ou Paredes: a escola em tempos de dispersão. Rio de Janeiro: Contraponto, 2012.

SILVA, M. L. P. As favelas Cariocas: 1930-1964. Rio de Janeiro: Contraponto, 2005.

SILVA, P. Escola-família, uma relação armadilhada: interculturalidade e relações de poder. Santa Maria da Fé: Edições Afrontamento, 2003.

SOARES, C. Z. Segregação urbana, geografia de oportunidades e desigualdades educacionais no Rio de Janeiro. 2009. 160 f. Dissertação de mestrado, UFRJ, Instituto de Pesquisa e Planejamento Urbano e Regional: Rio de Janeiro, 2009.

SOARES, J. F.; As desigualdades socioespaciais e o efeito das escolas públicas de Belo Horizonte. In: RIBEIRO; L. C. Q. ; KAZTMAN, R. (Org). A cidade contra a escola:Segregação urbana e desigualdades educacionais em grandes cidades da América Latina; Rio de Janeiro: Letra Capital, 2008.

THIN, D. Para uma análise das relações entre famílias populares e escola: confrontação entre lógicas socializadoras. Revista Brasileira de Educação, v. 11, n. 32, p. 211- 236, 2006.

VALLADARES, L. do P. A Gênese da favela carioca: a produção anterior às Ciências Sociais. Revista Brasileira de Ciências Sociais, v. 15, n. 44, p.35-49 2000.

VELHO. G. Um antropólogo na cidade: ensaios de antropologia urbana. Rio de Janeiro: Zahar, 2013.

WESTBROOK, R. B. John Dewey / Robert B. Westbrook; Anísio Teixeira, José Eustáquio Romão, Verone Lane Rodrigues. Recife: Fundação Joaquim Nabuco/ Editora Massangana, 2010. 


\section{Anexos}

\section{ENTREVISTA INDIVIDUAL DIREÇÃODA ESCOLA}

Objetivos:

Compreender como os diretores e diretoras percebem a vizinhança, os pais e responsáveis e de que maneira eles julgam que as características do território e das pessoas que o habitam podem incidir sobre o trabalho escolar. Identificar ainda ações concretas dos diretores/diretoras no sentido de aproximar ou afastar as escolas das famílias e como a escola desenvolve ou não ações de proximidade com seu entorno.

Nome da Escola:

Nome do (a) Diretor(a):

1. DADOS SOBRE A EXPERIÊNCIA PROFISSIONAL DO ENTREVISTADO:

a) Qual a sua formação acadêmica? Por que escolheu a área de educação?

b) Há quanto tempo atua na área de educação?

c) Há quanto tempo atua como diretor/a? Já teve outra experiência como essa? Como foi?

d) Qual seria, na sua opinião, o maior desafio na sua profissão?

\section{IDENTIDADE ESCOLAR}

a) Há quantos anos está escola existe?

b) Há algum fato na história desta escola que você considere importante destacar? Qual?

c) Você diria que esta escola tem uma "marca", uma identidade reconhecida pela comunidade escolar e pela vizinhança do entorno? Qual?

3. PAPEL DA ESCOLA

a) $\mathrm{Na}$ sua opinião, o fato de a escola se localizar em uma favela/comunidade a diferencia de outras escolas que não se localizam em territórios como esses? Explique, por favor.

b) Qual seria a principal função de uma escola localizada na favela para além do ensino escolar propriamente?

c) escola construiu suas metas pedagógicas próprias ou adotou metas designadas pela SME-RJ? Caso a escola elabore suas próprias metas, como isso é feito?

d) Os pais e alunos participam da elaboração dos objetivos e metas? Como? Se não participam, o que explicaria, no seu ponto de vista, essa falta de participação?

e) Na sua opinião, os professores ao realizarem seu planejamento deveriam prever atividades que envolvessem os pais/responsáveis? Se sim, quais? Se não, por quê?

\section{ALUNOS: EXPECTATIVAS SOBRE A TRAJETÓRIA ESCOLAR}


a) Qual o perfil dos alunos desta escola? Em que dados você se baseia?

b) Qual o percentual de reprovação e desistência?

c) $\mathrm{Na}$ sua opinião, quais são os principais fatores para a reprovação e desistência?

d) Há alguma ação da escola a respeito dos alunos que são reprovados ou que deixam a escola? Explique quais, por favor.

e) Qual a sua expectativa quanto ao futuro acadêmico dos alunos? Que nível de ensino você acredita que a maioria deles alcançará?

f) Que fatores escolares e que fatores externos podem influenciar no futuro acadêmico dos seus alunos, de acordo com seu ponto de vista?

\section{RELACIONAMENTO ESCOLA, FAMÍLIA E VIZINHANÇA}

\section{a. Famílias}

a) Quando os alunos/alunas chegam na escola como é organizada a entrada?

b) Você conhece ou tem ideia do nível escolar dos pais ou responsáveis de seus alunos?

c) Acha que esse dado é importante para o planejamento das atividades escolares? Por quê?

d) Você acredita, de acordo com sua experiência, que a composição e características familiares podem incidir sobre o desempenho dos alunos na escola? Por quê?

e) Como você avalia a participação das famílias na educação escolar dos filhos? Acha que a escola poderia/deveria incidir sobre esse processo?

f) Como você se comunica com as famílias de seus alunos?

g) Existem reuniões de entregas de boletins e outros comunicados? Como são essas reuniões? Quem conduz as reuniões? Como você as avalia?

h) As famílias são convidadas a comparecer na escola fora das reuniões de entrega de boletins? Em que circunstâncias?

i) Existe alguma organização de pais atuante na escola? Como ela funciona? Se não existe, acha que deveria existir? Por quê?

j) $\mathrm{Na}$ escola existem espaços físicos que são frequentados pelas pessoas da vizinhança? Se sim, quais são e como funcionam? Se não, você acha que deveriam existir tais espaços? Por quê?

\section{2 pais e professores}

k) Como você avalia a interação entre professores e pais/responsáveis no cotidiano? Quais são as questões mais recorrentes que chegam até você no que tange a essa relação? Como elas são encaminhadas?

1) Nos conselhos de classe, a questão da família aparece? De que forma?

m) Existem cursos ou reuniões de formação para professores onde a temática da relação escola-família esteja presente? Você considera importante que isso aconteça? 
n) Você pode identificar as características, qualidades e os problemas da vizinhança da escola?

\subsection{Vizinhança}

o) Na sua opinião a vizinhança da escola interfere no trabalho institucional e/ou nos resultados escolares dos alunos? De que maneira?

p) A escola fez ou faz algum tipo de parceria com pessoas ou instituições da vizinhança? Se faz, quais são e como funcionam? Se não faz, você acha que deveria fazer? Quais?

q) Existe ou existiu algum programa ou projeto governamental na escola? Qual (ais)?

r) Você conhece ou já ouviu falar do projeto Bairro Educador?

\section{PROGRAMA ESCOLAS DO AMANHÃ (PEA) (onde existe o} Programa):

a) Como funciona o PEA na escola?

b) Quais os principais objetivos do PEA?

c) Na sua avaliação o PEA é um programa importante para a escola? Por favor explique.

d) O que, no Programa, você ressaltaria como positivo e o que seria negativo?

e) Como você avalia a participação dos professores da escola no PEA?

\section{BAIRRO EDUCADOR (para escolas que fizeram parte do Projeto)}

a) Como funcionava o Bairro Educador na escola?

b) Você lembra quais eram os principais objetivos do Projeto?

c) Os professores e demais profissionais da escola se envolveram nas ações do Bairro Educador?

d) Na sua opinião o Projeto contribuiu para a escola? De que maneira?

e) O que poderia ter sido melhor?

f) Gostaria que ele tivesse continuado? Por quê?

g) Você acha que o Bairro Educador aproximou a escola da comunidade/vizinhança? Como?

8. Por fim, como você avalia, de modo geral, a relação entre a escola e as famílias dos alunos? 


\section{ENTREVISTA INDIVIDUAL PROFESSOR/PROFESSORA DA ESCOLA}

Objetivos:

Compreender como os professores percebem e se relacionam com a vizinhança, os pais e responsáveis e demais profissionais da escola e de que maneira eles julgam que as características do território e das pessoas que o habitam podem incidir sobre o trabalho escolar. Identificar ainda ações concretas dos professores no sentido de se aproximarem ou afastarem-se das famílias e da vizinhança.

Nome da Escola:

Nome do (a) professor (a)

Questões:

\section{Dados sobre a experiência profissional do entrevistado:}

a) Há quanto tempo você atua como professor/a nesta escola?

b) Por que escolheu a área de educação para atuar? Qual a sua formação acadêmica?

c) Qual seria, na sua opinião, o maior desafio na sua profissão hoje?

\section{PAPEL DA ESCOLA}

(Como os agentes enxergam o papel ou papéis da escola no território para além do ensino de conteúdos acadêmicos) (geografia de oportunidades)

a) Qual seria a principal função de uma escola para além do ensino dos conteúdos escolares propriamente?

b) Existem diferenças entre escolas localizadas nas favelas e escolas localizadas fora delas? Quais?

c) Que objetivos e metas desta escola você destacaria como mais importantes? Como as metas são elaboradas?

3. ALUNOS: EXPECTATIVAS SOBRE A TRAJETÓRIA ESCOLAR (O que os agentes esperam dos alunos em termos acadêmicos a partir da ação da escola)

a) Qual o perfil dos alunos desta escola? Em que dados você se baseia?

b) Sobre a evasão e a reprovação: quais são os percentuais?

c) O que a escola faz quando tem alunos com baixo rendimento escolar?

d) Até que nível de ensino você acredita que a maioria dos alunos desta escola conseguirá alcançar? Explique, por favor.

4. RELACIONAMENTO ESCOLA, FAMÍLIA E VIZINHANÇA (Entender como essas instituições se relacionam e quais são as influências, questões, problemas que podem aproximá-las ou afastálas)

\section{1 famílias}


a) A composição e características familiares podem incidir sobre o desempenho dos alunos na escola? Como?

b) Como você avalia a participação dos pais/responsáveis de seus alunos/as na escolarização dos filhos/as?

\subsection{Pais e professores}

c) Como você se comunica com as famílias de seus alunos e quais são os assuntos mais tratados tanto em espaços formais como informais?

d) Nos conselhos de classe a questão da família aparece? Como?

e) Existem cursos ou reuniões de formação para professores onde a temática da relação escola-família esteja presente? O que você pensa a respeito disso?

Vizinhança

f) Em sua opinião, a vizinhança escolar, a comunidade/favela pode influenciar no seu trabalho e/ou nos resultados escolares dos alunos? De que maneira?

g) A escola ou você fez ou faz algum tipo de parceria com pessoas ou instituições da vizinhança? Quais?

\section{PROGRAMA ESCOLAS DO AMANHÃ (PEA) (onde existe o Programa):}

a) Você conhece ou já ouviu falar do PEA?

b) O que, no Projeto, você ressaltaria como positivo e o que seria negativo?

c) Como você avalia a participação dos professores da escola no PEA?

6. BAIRRO EDUCADOR (para escolas que fizeram parte do Projeto)

a) Você conhece ou já ouviu falar no Bairro Educador?

b) Os professores e demais profissionais da escola se envolveram nas ações do Bairro Educador?

c) Em sua opinião o Projeto contribuiu para a escola se aproximar mais da vizinhança? De que maneira?

7. Por fim, como você avalia, de modo geral, a relação entre a escola e as famílias dos Alunos? 


\section{ENTREVISTA INDIVIDUAL PAIS E RESPONSÁVEIS PEDAGÓGICOS}

\section{OBJETIVOS:}

Compreender como os pais e responsáveis percebem a vizinhança, os professores, diretores, demais profissionais da escola e de que maneira eles julgam que as características do território e das pessoas que o habitam podem incidir sobre o trabalho escolar. Tentar compreender como esses agentes se relacionam de maneira geral com a instituição escolar e como participam da escolarização de seus filhos e filhas. Identificar ainda ações concretas dos pais e responsáveis no sentido de se aproximarem ou afastarem-se das escolas e da vizinhança.

Nome da Escola:

Nome do (a) Pai/mãe ou responsável (a):

\section{Questões:}

\section{Dados sobre entrevistado:}

(Quem é o entrevistado/a)

a) Há quanto tempo você mora nesta comunidade/favela?

b) Gosta de morar aqui? Por quê?

c) Qual a composição de sua família?

\section{PAPEL DA ESCOLA}

(Como os agentes enxergam o papel ou papéis da escola no território para além do ensino de conteúdos acadêmicos) [geografia de oportunidades]

a) Há quanto tempo seu filho/a estuda nessa escola? Por que você escolheu esta escola? Tem diferença de uma escola localizada na favela e outra fora daqui?

b) Qual seria a principal função de uma escola para além do ensino dos conteúdos escolares propriamente?

c) Você acha que uma escola pode ajudar a melhorar a comunidade? Como?

\section{ALUNOS: EXPECTATIVAS SOBRE A TRAJETÓRIAS ESCOLARES}

(O que os agentes esperam dos alunos em termos acadêmicos a partir da ação da escola)

a) Conte, por favor, como era a escola que frequentou quando criança.

b) Como é a participação de sua família na educação escolar de seus filhos/filhas? Quem toma "à frente"?

c) Tem algum lugar na casa para seu filho/filha estudar?

d) Você conversa com seu filho/filha sobre a escola? Sobre o que mais conversam?

e) Qual o nível de estudos você acredita que seu filho/filha pode alcançar? 
f) Você acha que os professores e professoras da escola acreditam que as crianças podem chegar a níveis mais elevados de educação escolar?

\section{RELACIONAMENTO ESCOLA, FAMÍLIA E VIZINHANÇA}

(Entender como essas instituições se relacionam e quais são as influências, questões, problemas que podem aproximá-las ou afastá-las)

A escola

a) Como você avalia a relação entre professores e pais/responsáveis no dia a dia na escola?

b) Como são as reuniões com os professores e direção da escola?

c) Você compareceu a escola fora das reuniões de entrega de boletins? Em que momentos?

d) Existe alguma organização de pais atuante na escola? Como ela funciona?

\section{A vizinhança}

e) Por favor, fale das características, qualidades e os problemas da sua vizinhança? Acredita que a vizinhança interfere no trabalho da escola? Se sim, como?

f) Você conhece e/ou frequenta alguma organização social privada, comunitária ou pública na sua comunidade/favela?

g) Você conhece os colegas de escola do seu filho/filha? E os pais/responsáveis?

h) Que espaços ou lugares na comunidade/favela seus filhos/as frequentam além da escola?

\section{PROGRAMA ESCOLAS DO AMANHA:}

a) Você conhece ou já ouviu falar do projeto Escolas do Amanhã?

b) Sabe como ele funcionava?

c) Se sim, o que destacaria como positivo?

6. BAIRRO EDUCADOR (para escolas que fizeram parte do Projeto)

a) Você ouviu falar do projeto Bairro Educador na escola de seu filho/filha?

b) Na sua opinião o Projeto contribuiu para a escola se aproximar mais da vizinhança e das famílias dos estudantes? De que maneira?

7. Por fim, como você avalia, de modo geral, a relação entre a escola e as famílias dos alunos/as? 


\section{ENTREVISTA INDIVIDUAL GESTOR DO PROJETO}

Objetivo: Compreender como os gestores concebem o PEA/Bairro Educador, como avaliam sua implementação nas escolas e como enxergam as relações escola-família-território a partir das ações do Programa.

Nome:

FUNÇÃO:

Questões:

1. DADOS SOBRE A EXPERIÊNCIA PROFISSIONAL DO ENTREVISTADO:

a) Por que escolheu a área de educação para atuar? Qual a sua formação acadêmica?

b)Qual seria, na sua opinião, o maior desafio hoje da educação escolar na cidade?

c) Qual seria a principal função de uma escola, principalmente as localizadas nas favelas, para além do ensino dos conteúdos escolares propriamente?

\section{O PROGRAMA ESCOLAS DO AMANHÃ/BAIRRO EDUCADOR}

a) Como foi pensado inicialmente o PEA? Pq ele foi criado?

b)Que objetivos e metas você destacaria como mais importantes no PEA?

c) Como o PEA foi implementado? Como chegou nas escolas?

d)Houve mudanças no Programa do início para hoje? Quais as principais?

e) Sobre o Bairro Educador, como ele foi pensado inicialmente? Quais os seus principais objetivos? Quais as maiores dificuldades e avanços?

f) Como Você avalia o Programa?

\section{RELACIONAMENTO ESCOLA, FAMÍLIA E VIZINHANÇA}

\subsection{Famílias}

a) Como a SME se comunica com as famílias?

b)Existe uma representação de pais junto a SME-RJ? Quais são os assuntos mais tratados?

c) Como você avalia a participação dos pais/responsáveis na escolarização dos filhos/as?

\subsection{Vizinhança}

a) Em sua opinião, a vizinhança escolar, a comunidade/favela pode influenciar no trabalho e/ou nos resultados escolares dos alunos? De que maneira? 
b) Como você avalia as parcerias das escolas com as instituições locais para o funcionamento dos Programas?

\subsection{Professores}

c) Houve resistência dos professores quando da implementação do PEA/Bairro Educador?

d) Existem cursos ou reuniões de formação para professores onde a temática da relação escola-família esteja presente? Há algum incentivo para que as escolas discutam esse tema?

4. Por fim, como você avalia, de modo geral, a relação entre a escola e as famílias dos Alunos? 


\section{ENTREVISTA INDIVIDUAL COM PRESIDENTES ASSOCIAÇÃO DE MORADORES}

\section{OBJETIVOS:}

Compreender como os presidentes das associações de moradores percebem a vizinhança, os professores, diretores, demais profissionais da escola e de que maneira eles julgam que as características do território e das pessoas que o habitam podem incidir sobre o trabalho escolar. Tentar compreender como esses agentes se relacionam de maneira geral com a instituição escolar e como, a partir de suas intuições, interagem com a educação escolar no território.

Nome da Comunidade/favela:

Nome:

\section{Questões:}

1. DADOS SOBRE A EXPERIÊNCIA DO/A ENTREVISTADO/A COM SUA PRÓPRIA ESCOLARIZAÇÃO:

a) Há quanto tempo mora nesta comunidade/favela? Como chegou aqui?

b) Tem parentes na comunidade/favela? Se relaciona com eles?

c) Como chegou à Associação de Moradores?

d) Quais as maiores dificuldades para dirigir uma Associação de Moradores?

\section{IDENTIDADE ESCOLAR}

(Captar com a escola é vista e se faz ver no território)

a) Você sabe há quantos anos a escola existe em sua comunidade/favela?

b) A comunidade/favela em que a escola está localizada tem alguma marca ou apelido? Sabe da sua origem?

c) Você conhece o nome do diretor/a da escola?

d) Já foi convidado para ajudar na escola?

e) Como a Associação se relaciona com a escola?

\section{PAPEL DA ESCOLA}

(Como os agentes enxergam o papel ou papéis da escola no território para além do ensino de conteúdos acadêmicos) [geografia de oportunidades]

a) Na sua opinião, o fato da escola se localizar em uma comunidade/favela a diferencia de outras escolas que não se localizam em territórios como esses?Explique, por favor.

b) Você ou alguém da sua Associação foi convidado/a participar de discussões sobre metas escolares ou algo assim, pela escola?

c) Na sua opinião qual seria a principal função de uma escola localizada na comunidade/favela para além do ensino escolar propriamente? 


\section{ALUNOS: EXPECTATIVAS SOBRE A TRAJETÓRIAS} ESCOLARES

(O que os agentes esperam dos alunos em termos acadêmicos a partir da ação da escola)

a) Conte, por favor, como era a escola que frequentou quando criança. Do que mais gostava e do que não gostava? Lembra de algum professor, diretor ou funcionário?

b) Se não frequentou a escola, por favor, explique os motivos. Gostaria de ter frequentado?

c) Você tem ou teve filhos/filhas matriculados na escola da sua comunidade/favela?

d) Na sua opinião as escolas da comunidade/favela estão preparadas para atender as necessidades educacionais das crianças da Maré? Por quê?

e) Até que nível de ensino você acha que a maioria das crianças da Maré chegará?

\section{RELACIONAMENTO ESCOLA, FAMÍLIA E VIZINHANÇA} (Entender como essas instituições se relacionam e quais são as influências, questões, problemas que podem aproximá-las ou afastálas)

a) Por favor, fale das características, qualidades e os problemas da sua vizinhança?

b) Acredita que a vizinhança interfere no trabalho da escola? Se sim, como?

c) Você foi convidado ou conhece alguém da vizinhança que foi convidado para fazer parceria com a escola?

d) Você conhece alguma organização de pais atuante nas escolas?

e) Como ela funciona? Se não existe, acha que deveria existir? Por quê?

f) Na escola existem espaços físicos onde as pessoas da vizinhança podem frequentar? Se sim, quais são e como funcionam? Se não, você acha que deveriam existir tais espaços? Por quê?

g) Você conheceu ou conhece algum programa ou projeto governamental na escola de sua comunidade/favela? Quais?

\section{PROGRAMA ESCOLAS DO AMANHA:}

a) Você conhece ou já ouviu falar do projeto Escolas do Amanhã nas escolas de sua comunidade/favela?

b) Você sabe como ele funciona?

c) Você tem conhecimento se os professores e demais profissionais da escola se envolvem nas ações PEA?

d) $\mathrm{Na}$ sua opinião o Projeto contribuiu para a melhoria do ensino nas escolas? Por quê?

7. BAIRRO EDUCADOR (para escolas que fizeram parte do Projeto)

a) Você já ouviu falar ou lembra do projeto Bairro Educador? 
b) A Associação de Moradores se envolveu nas ações do Bairro Educador?

c) Na sua opinião o Projeto contribuiu para que a escola se aproximasse mais da vizinhança e das famílias dos estudantes? De que maneira?

d) O que poderia ter sido melhor?

e) Gostaria que ele tivesse continuado? Por quê?

8. Por fim, como você avalia, de modo geral, a relação entre a escola e as famílias dos alunos/as? 